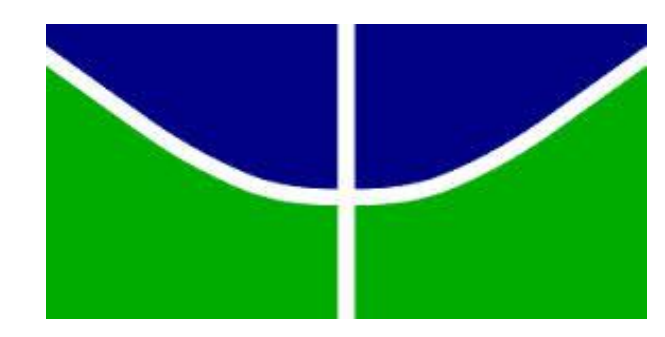

UNIVERSIDADE DE BRASÍLIA - UNB

INSTITUTO DE LETRAS - IL

DEPARTAMENTO DE TEORIA LITERÁRIA E LITERATURAS - TEL PROGRAMA DE PÓS-GRADUAÇÃO EM LITERATURA - PÓSLIT

AMOR E MONSTRUOSIDADE EM NOTRE-DAME DE PARIS: DA LITERATURA À DANÇA

PRISCILA FERNANDES DE OLIVEIRA

DISSERTAÇÃO DE MESTRADO EM LITERATURA

BRASÍLIA - DF

AGOSTO DE 2015 


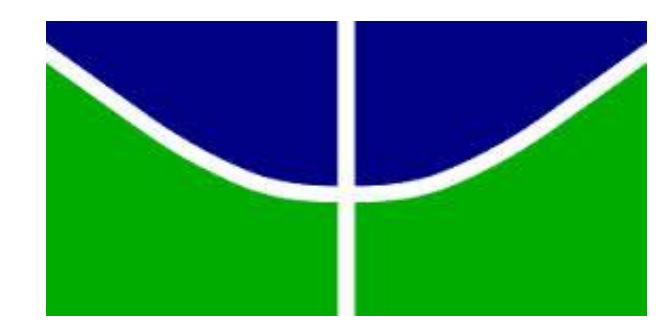

UNIVERSIDADE DE BRASÍLIA - UNB

INSTITUTO DE LETRAS - IL

DEPARTAMENTO DE TEORIA LITERÁRIA E LITERATURAS - TEL

PROGRAMA DE PÓS-GRADUAÇÃO EM LITERATURA - PÓSLIT

Amor e monstruosidade em Notre-Dame de Paris:

da literaratura à dança

Dissertação de Mestrado submetida ao Programa de Pós-Graduação em Literatura como parte dos requisitos necessários à obtenção do grau de mestre em Literatura.

Orientadora: Prof ${ }^{\mathrm{a}}$. Dra ${ }^{\mathrm{a}}$. Junia R. de Faria Barreto 
Ficha catalográfica elaborada automaticamente, com os dados fornecidos pelo(a) autor(a)

Amor e monstruosidade em Notre-Dame de Paris: da literatura à dança / Priscila Fernandes Oliveira;

orientador Barreto Junia Regina F... -- Brasília, 2015 $159 \mathrm{p}$.

Dissertação (Mestrado - Mestrado em Literatura) -Universidade de Brasília, 2015.

1. Notre-Dame de Paris. 2. Literatura. 3. Dança. 4. Monstruosidade. 5. Amor. I. Junia Regina F., Barreto, orient. II. Título. 
OLIVEIRA, Priscila Fernandes. Amor e monstruosidade em Notre-Dame de Paris: da literatura à dança. Dissertação apresentada ao Programa de Pós-Graduação em Literatura, do Instituto de Letras, da Universidade de Brasília, como requisito parcial para a obtenção do título de Mestre em Literatura.

Aprovado em 31 de agosto de 2015, por:

Prof $\mathrm{Dr}^{3}$. Junia Regina de Faria Barreto (TEL/UnB)

(Orientadora)

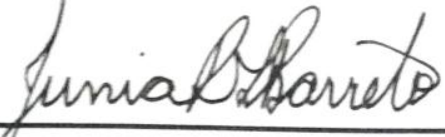

Prof. Dr². Mariana de Rosa Trotta (EEFD/UFRJ)

(Examinadora externa)

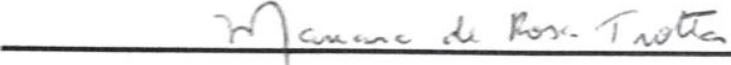

Prof. Dra. Soraia Maria Silva (IdA/UnB)

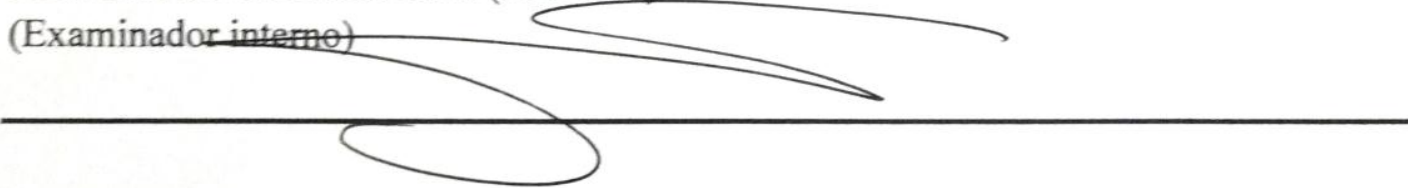

Prof. Dra. Sylvia Helena Cyntrão (TEL/UnB)

(Suplente)

Brasília, 31 de agosto de 2015 
À Marly Santos Cruz, in memoriam,

pelo exemplo de força e perseverança, do qual jamais me esquecerei. 


\section{AGRADECIMENTOS}

Ao Departamento de Teoria Literária e Literaturas (TEL) da Universidade de Brasília e, em especial, ao seu Programa de Pós-graduação em Literatura (PósLIT), pela acolhida que me possibilitou desenvolver este trabalho.

À Prof ${ }^{\mathrm{a}}$. Dr ${ }^{\mathrm{a}}$ Júnia Regina de Faria Barreto, minha orientadora, por acreditar no meu potencial, sempre me incentivando a prosseguir, sobretudo nos momentos mais difíceis.

Ao CNPQ, pelo apoio financeiro necessário à realização desta pesquisa.

Às professores doutoras Mariana de Rosa Trotta, Soraia Maria Silva e Sylvia Helena Cyntrão que, tão gentilmente, aceitaram ler e avaliar este trabalho.

Ao Grupo de Pesquisa Victor Hugo e o século XIX, que tanto contribuiu para a realização deste trabalho. Em especial a Lucas Kadimani, Luiz Capelo e Guilherme Santos, pela ajuda com as revisões e traduções.

Aos meus pais, Marly Santos Cruz e Evaldo Fernandes de Oliveira, pelos ensinamentos de toda uma vida. Às minhas irmãs Patrícia Fernandes de Oliveira, Angélica Fernandes de Oliveira e à minha tia Valdeci Fernandes das Graças, pelo amor e apoio.

Ao Corpo de Dança SESC de Taguatinga Sul e à professora Keyla Coury Araújo, por me apresentarem ao maravilhoso universo da dança.

Aos meus amigos, pelo carinho de sempre.

E, por fim, a Deus sem a quem eu nada seria. 
"E aqueles que foram vistos dançando foram julgados insanos por aqueles que não podiam escutar a música." Friedrich Nietzsche 


\section{RESUMO}

A relação entre literatura e dança é antiga e ocorre sob diversas formas. A escritura frequentemente serve como referência para criações coreográficas, assim como a dança insere-se como elemento fundamental em algumas narrativas. Os estudos sobre a dança na literatura são numerosos. Entretanto, pesquisas que perfazem o caminho oposto, analisando a transposição da obra literária para a dança, são praticamente inexistentes, deixando uma série de indagações a respeito dessa forma de recriação. Portanto, identificar e questionar as dinâmicas envolvidas no processo de metamorfose de um código para outro, ou seja, da palavra escrita ao movimento, constitui o cerne desta pesquisa.

Com o propósito de tentar responder a essas questões e analisar o diálogo intersemiótico entre essas artes, propomos um estudo comparativo entre o romance Notre-Dame de Paris de Victor Hugo e a adaptação coreográfica desta obra para o ballet neoclássico realizada pelo coreógrafo Roland Petit. No processo de análise das obras, focaremos nas relações de amor e monstruosidade, investigando as principais divergências e convergências entre ambas as obras.

A fim de lograr em nosso empreendimento, tomaremos como base os estudos semióticos para a análise da dança-espetáculo de Mariana de Rosa Trotta, os quais consideram a dança como um fenômeno complexo de linguagem em que elementos como a gestualidade, a música, o cenário e o figurino compõe um todo de sentido. A partir desta perspectiva, buscaremos entender, nesta pesquisa como a música de Maurice Jarre, o figurino de Yves Saint Laurent, o cenário de René Allio, a iluminação de Jean-Michel Désirée e a coreografia de Roland Petit contribuem para a escritura da narrativa coreográfica, agregando sentidos para a adaptação do texto hugoano.

Palavras-chave: Notre-Dame de Paris, literatura, dança, monstruosidade, amor. 


\section{RESUMÉ}

Le rapport entre littérature et danse est ancien et se produit sous plusieurs formes. L'écriture sert souvent comme référence pour des créations chorégraphiques, ainsi que la danse s'insère comme élément fondamental dans quelques récits. Les études sur la danse dans la littérature sont nombreuses. Pourtant, les recherches qui parcourent le chemin opposé, en analysant la transposition de l'œuvre littéraire à la danse, sont presque inexistantes. Ainsi, ce manque nous laisse une série de questionnements par rapport à cette manière de recréation. Identifier et questionner les dynamiques appartenant au processus de métamorphose d'un code à l'autre, c'est-à-dire du mot écrit au mouvement, constituent donc le noyau de cette recherche.

Dans le but d'essayer de répondre à ces questions et d'analyser le dialogue intersémiotique parmi ces arts, nous nous proposons une étude comparative entre le roman Notre-Dame de Paris, de Victor Hugo, et l'adaptation chorégraphique de cette œuvre pour le ballet néoclassique mis en scène par le chorégraphe Roland Petit. Dans le processus d'analyse des œuvres, nous nous centrerons sur les relations d'amour et monstruosité, en investiguant les principales divergences et convergences entre les deux œuvres.

Afin d'avoir les résultats attendus dans notre entreprise, nous prendrons comme base les études sémiotiques pour l'analyse de la danse-spectacle de Mariana de Rosa Trotta, selon lesquelles la danse est considérée comme un phénomène complexe de langage où des éléments comme la gestualité, la musique, le décor et les costumes composent un ensemble portant du sens. Depuis cette perspective, nous chercherons à comprendre comment la musique de Maurice Jarre, les costumes d'Yves Saint Laurent, le décor de René Allio, l'éclairage de Jean-Michel Désiré et la chorégraphie de Roland Petit contribuent à l'écriture du récit chorégraphique, en ajoutant des sens à l'adaptation du texte hugolien.

Mots-clés: Notre-Dame de Paris,littérature, danse, monstruosité, amour. 
INTRODUÇÃ

CAPÍTULO I - Amor e monstruosidade....................................................................... 18

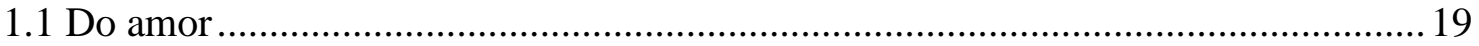

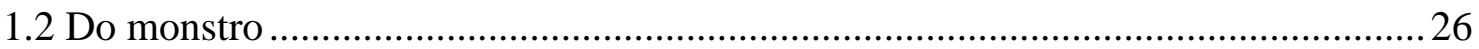

CAPÍTULO II - Narrativa textual: dizer e contar através de palavras ............................... 35

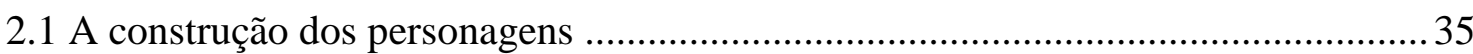

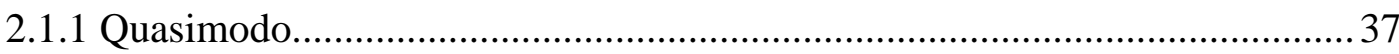

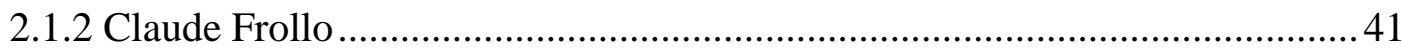

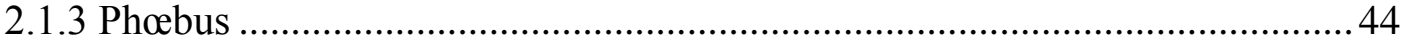

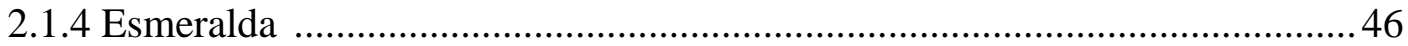

2.2 As relações de amor e monstruosidade ............................................................... 48

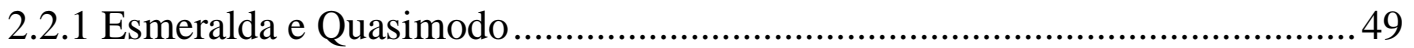

2.2.2 Claude Frollo e Esmeralda ….................................................................... 52

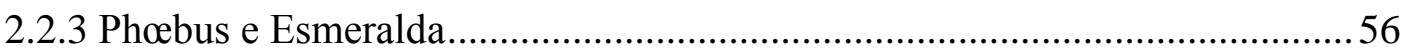

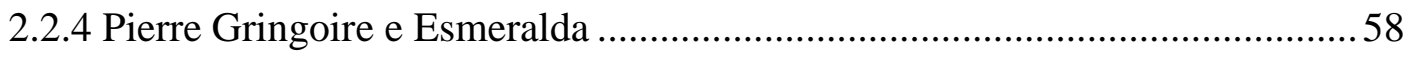

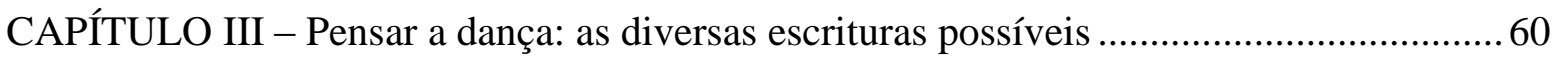

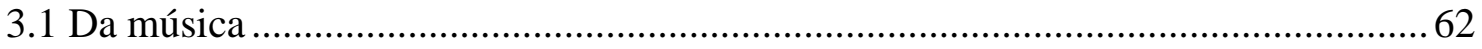

3.1.1 A escritura musical de Maurice Jarre .......................................................... 65

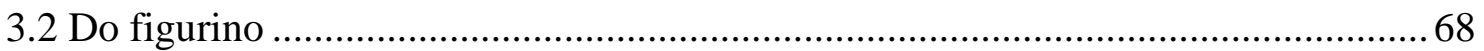

3.2.1 A escritura de Yves Saint Laurent ............................................................... 70

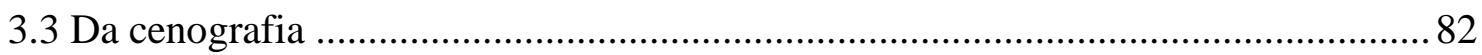

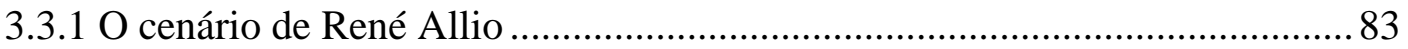

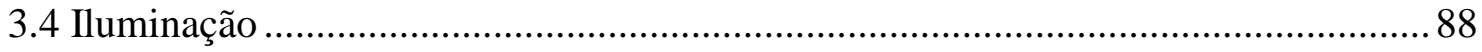

3.4.1 A iluminação de Jean-Michel Désiré ........................................................... 89

CAPÍTULO IV - Coreo-GRAFIA: a construção da narrativa gestual..................................93

4.1 Roland Petit: entre a dança e a literatura .................................................................. 94

4.1.1 O processo de adaptação ....................................................................... 96

4.1.2 Notre-Dame de Paris : uma história de amor e de morte ..............................96

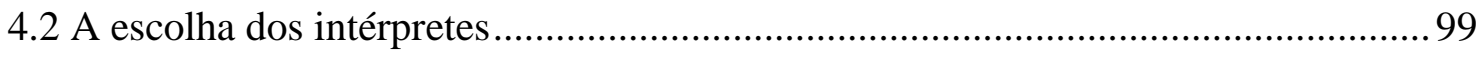

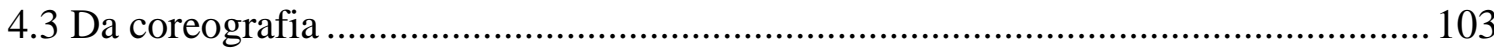


4.3.1 A construção dos personagens pela gestualidade 106

4.3.2 Monstruosidade e amor: a escrita pelo corpo ................................................ 116

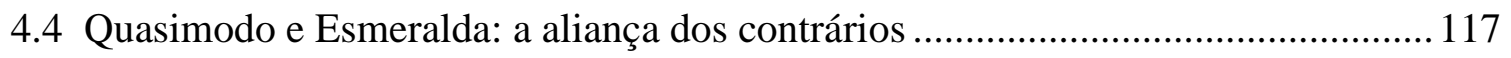

4.5 Claude Frollo e Esmeralda: da paixão à monstruosidade....................................... 121

4.6 Phœbus e Esmeralda: o amor carnal..................................................................... 129

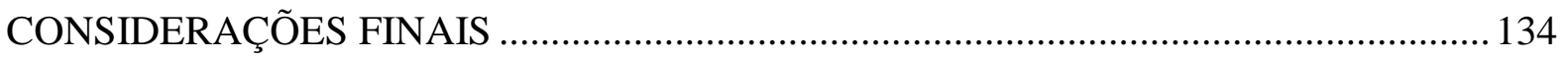

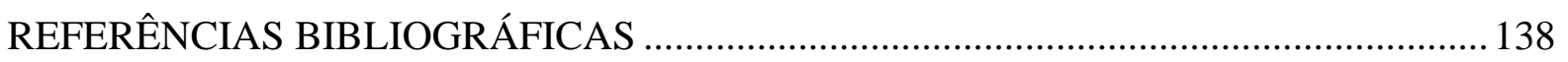

ANEXO I - Croquis dos figurinos de Notre-Dame de Paris por Yves Saint Laurent.......... 140

ANEXO II - Libreto do balé Notre-Dame de Paris por Roland Petit .................................. 158 


\section{INTRODUÇÃO}

A cumplicidade entre a literatura e a dança é antiga e ocorre sob múltiplas formas. Ao longo dos séculos, diversos autores serviram-se da dança como mote para a composição de suas obras e personagens, assim como obras literárias inspiraram diferentes criações coreográficas. A interação entre essas diferentes formas de arte é possível, pois ambas visam ultrapassar o paradigma da realidade, aguçando os sentidos, a subjetividade do ser e o imaginário por meio da linguagem.

As pesquisas que se concentram na análise da configuração da dança na literatura surgem com determinada frequência. Entretanto, poucos são os estudiosos a perfazer o percurso contrário, e são raras as investigações aprofundadas sobre a recriação de uma obra literária para a dança. A pesquisa na área suscita, naqueles que decidem se aventurar por esse caminho, uma série de indagações a respeito das dinâmicas envolvidas no processo de metamorfose de um código para outro, ou seja, na transformação da palavra escrita em movimento. Assim, com o objetivo de contribuir para o debate e de dialogar com as pesquisas existentes nesse domínio, propomos aqui alguns questionamentos e reflexões de tal processo.

Sabemos que, embora sejam artes correspondentes, a dança e a literatura configuram-se como códigos diferentes, os quais requerem seus próprios meios de expressão. Logo, a primeira grande perquisição que se impõe é: afinal, de que forma os diversos componentes de um texto literário transformam-se em passos, gestos, figurinos, cenários, música e iluminação de um balé, constituindo, então, uma obra estética autônoma e não uma mera ilustração do romance ?

A fim de tentar contribuirmos para o esclarecimento dessa questão e de analisar o processo criativo acima descrito, propomos um estudo comparativo entre o romance Notre-Dame de Paris, de Victor Hugo, e o balé homônimo realizado pelo coreógrafo Roland Petit. Para tanto, focaremos especificamente a representação das relações de amor e monstruosidade, prospectando em torno das principais divergências e convergências entre ambas as narrativas.

Ao nos debruçarmos sobre esse campo, algumas escolhas fizeram-se presentes, uma vez que a correlação entre essas duas formas de arte distintas solicita que adotemos alguns posicionamentos. Em um primeiro momento, coube-nos definir como a adaptação da obra literária de Hugo seria entendida nesta pesquisa. 
Segundo Linda Hutcheon, "trabalhar com adaptações significa pensá-las como obras inerentemente 'palimpsestuosas' assombradas a todo instante pelos textos adaptados"1, ou seja, ao afirmamos que uma obra é uma adaptação, assumimos sua relação declarada com outras obras. Ainda de acordo com Hutcheon, as adaptações são objetos estéticos em seu próprio direito. Apesar de terem uma relação declarada e definitiva com os textos anteriores, as adaptações são obras autônomas, são recriações.

Uma vez que o balé de Roland Petit se mostra como uma tradução do romance de Victor Hugo para outro sistema sígnico, entendemos que aquele deve ser interpretado como uma nova criação, independente esteticamente de sua fonte. De acordo com Walter Benjamim, a tradução relaciona-se com o original a partir da possibilidade de ultrapassar a vida desse. Nas traduções "[...] a vida do original alcança, de maneira constantemente renovada, seu mais tardio e vasto desdobramento"2. Assim, sob essa ótica, consideramos neste trabalho que a obra de Roland Petit mantém sua relação com o texto de Hugo ao lhe dar uma sobrevida, renovando-o e permitindo sua propagação ao longo do tempo. Logo, ainda que pautados nas obras literárias, os coreógrafos, estilistas, compositores, cenógrafos e iluminadores imprimem, em suas narrativas, suas crenças, seus objetivos e sua estilística, reinterpretando ou recriando o texto de origem. Assim, eles buscam ou aproximar, ou traduzir, ou equivaler, ou dialogar, ou corresponder, ou adaptar o texto literário para a dança, observando as possibilidades de imbricamento de um meio com o outro, tendo em vista aquilo que desejam expressar.

Uma vez definido o uso do conceito de adaptação em relação ao balé NotreDame de Paris, fez-se necessária a adoção de uma perspectiva teórica para empreendermos nossa análise sobre a correspondências entre dança e literatura. Assim, baseados nos estudos semióticos para a análise da dança-espetáculo de Mariana de Rosa Trotta, optamos por, nesta pesquisa, considerarmos a dança como uma arte sincrética, em que diversas linguagens atuam em co-presença. . "A motricidade humana é entendida como um fenômeno social, ou seja, a gesticulação natural, à medida que é aprendida e transmitida, como outros sistemas semióticos, transforma-se em gesticulação cultural."3 . Enquanto gesticulação cultural, a dança cria sentido para o homem, podendo ser entendida como uma forma de comunicação.

\footnotetext{
${ }^{1}$ HUTCHEON, 2011. p. 27

${ }^{2}$ BENJAMIN, 2001. p. 195

${ }^{3}$ TROTTA. 2010, p. 01
} 
Uma vez entendida como ato comunicativo, a dança adquire o status de linguagem, o qual pressupõe um destinatário-intérprete e um remetente-codificador. Em um espetáculo de dança, tais papéis são desempenhados, respectivamente, pelo público e pelo coreógrafo, que elabora um roteiro gestual dotado de valor estético a ser decodificado pelo espectador, ou seja, o receptor.

Ademais, é importante salientar que, enquanto linguagem, a dança deve ser entendida como um texto sincrético. Logo, para o estudo de uma obra coreográfica, devemos levar em conta não apenas os gestos produzidos pelos bailarinos, mas a música, o figurino, o cenário, a iluminação e o libreto. Juntos, esses elementos compõe um todo de sentido, e apenas analisando-os como tal é que podemos verificar as possibilidades de relação desses elementos com o conteúdo da obra literária.

É nesse âmbito que empreenderemos nossa análise sobre a recriação da narrativa hugoana na coreografia de Roland Petit. Desse modo, investigaremos como as diferentes escrituras de Yves Saint Laurent, René Allio, Maurice Jarre, Jean-Michel Désiré e Roland Petit corroboram para a construção da narrativa coreográfica de NotreDame de Paris.

Notre-Dame de Paris pode ser compreendido como um romance geneticamente híbrido, pois se trata de um texto narrativo com características próprias do gênero dramático, as quais favorecem as inúmeras adaptações dessa obra. Essa essência fora ressaltada pelo próprio Hugo ao explicar a gênese de seu livro: "Depois do romance pitoresco de Walter Scott, restará outro romance a ser criado, mais belo e mais completo sob nossa perspectiva. Um romance ao mesmo tempo drama e epopeia; pitoresco, mas poético; real, mas ideal."4

Assim, em Notre-Dame de Paris, Hugo conduz o leitor por uma narrativa nãolinear, com digressões do narrador e reflexões sobre temas como: as relações sociais, políticas e de poder; a monstruosidade; a transição entre a Idade Média e o Renascimento (marcada pelo advento da imprensa); o combate aos demolidores do patrimônio arquitetônico; entre outros. Essas discussões são apresentadas por meio de uma trama baseada na fatalidade e nos vínculos afetivos que unem Esmeralda aos personagens masculinos de Quasimodo, Phœbus, Claude Frollo e Pierre Gringoire ( este ausente no balé).

\footnotetext{
${ }^{4}$ HUGO apud TAPIE
} 
Por sua vez, Roland Petit exerce um trabalho de delimitação tanto do enredo hugoano, repleto de tramas e personagens secundários, quanto de seu conteúdo intelectual. Sua narrativa concentra-se na história e nas relações amorosas de apenas quatro personagens do romance: Esmeralda, uma dançarina cigana, objeto do desejo perverso do padre Claude Frollo; Phœbus, capitão sedutor por quem a dançarina se apaixona; e Quasimodo, um monstruoso sineiro que nutre um amor impossível pela bela Esmeralda.

De acordo com o coreógrafo, sua obra configura-se como uma história de amor e de morte, atemporal e universal. Posto isso, buscaremos entender e investigar de que forma a faceta trágica da obra hugoana revela-se na dança.

Visando a cumprir os objetivos estabelecidos, esta pesquisa foi textualmente segmentada em quatro capítulos. Em um primeiro momento, empreendemos uma investigação, por meio de uma perspectiva filosófica, das principais definições e conceitos de amor e monstruosidade, principalmente no que tange os períodos de elaboração das obras e de desenvolvimento da trama.

Em um segundo momento, buscamos identificar de que forma os elementos retratados na narrativa coreográfica são abordados no romance. Para tanto, realizamos um mapeamento dos vínculos afetivos que unem Esmeralda, Quasimodo, Claude Frollo e Phœbus, investigando como se dão as relações de amor e monstruosidade na narrativa textual.

Em um terceiro tempo, procuramos demonstrar como a música de Maurice Jarre, o figurino de Yves Saint Laurent, o cenário de René Allio e a iluminação de JeanMichel Désiré contribuem para a composição do balé, agregando sentido para a adaptação do texto hugoano.

Por fim, no último capítulo, analisamos como a gestualidade, enquanto escritura, colabora para o contrato de comunicação estabelecido entre o coreógrafo e o público. Para tanto, buscamos abordar os diversos elementos envolvidos nesse processo, tais como a concepção da obra por Roland Petit; a elaboração do argumento do balé; a escolha dos personagens, bem como a dos principais bailarinos; a construção da narrativa através dos movimentos e como o amor e a monstruosidade são representados pela dança.

Ademais, inserimos em anexo os croquis dos figurinos elaborados pelo estilista Yves Saint Laurent; a tradução do livreto do balé concebido por Roland Petit; e uma 
cópia do DVD a partir do qual elaboramos nossa pesquisa. Sabemos que a escolha em trabalhar com um balé registrado em vídeo suscita uma série de problemas que são inerentes a esse tipo de suporte, pois a câmera proporciona uma percepção da obra distinta daquela do olhar do espectador. Entretanto, acreditando na possibilidade de se investigar o tema proposto por esse meio, não nos debruçamos sobre essas questões específicas, que nos restarão como objeto para reflexões e discussões futuras. 


\section{CAPÍTULO I}

\section{Amor e Monstruosidade}

Fonte de emoções e de conflitos do homem, o amor é um mote literário frequentemente abordado. Essa temática, rica e inesgotável, permeou as mais diversas obras ao longo dos séculos, sendo mote para reflexões em diferentes campos, como, por exemplo, as ciências humanas, sociais, ou biológicas; as artes; o campo da linguagem e a teoria e práticas literárias. Enquanto matéria-prima nas mãos de escritores e pensadores, o amor pode expressar tanto uma síntese das relações individuais e sociais, como exprimir a profunda relação entre a literatura e a sociedade. Assim, percorrendo textos, autores e períodos históricos distintos, é possível depreender, através da representação dos diferentes elos e expressões de amor neles retratados, as relações e os valores inerentes a cada época.

De maneira semelhante ao amor, a temática da monstruosidade, que está presente no imaginário popular desde os tempos primórdios, sempre despertou o interesse e o fascínio de autores e estudiosos. Segundo Gil, tal fato se justificaria por uma única razão: o homem se define em oposição ao monstro. Isto é, por meio da figura monstruosa o homem questiona não apenas sua própria humanidade como seu lugar no mundo. Logo, "seria possível traçar a história das diferentes ideias ou definições que o homem deu a si próprio através das diversas representações da monstruosidade humana que o acompanharam."

Mas afinal, como duas temáticas aparentemente tão distintas podem se imbricar? Victor Hugo parece nos oferecer essa resposta a partir da trama de Notre-Dame de Paris. No romance, a narrativa se desenvolve a partir das relações de afeto estabelecidas entre os personagens, dentre os quais figuram dois tipos de monstro. Quasimodo, denominado como monstro físico devido às suas deformidades corpóreas, devota um amor impossível pela dançarina Esmeralda, a qual lhe demonstra apenas amizade e gratidão. Por sua vez, o padre Claude Frollo alimenta um desejo perverso por Esmeralda, o qual o conduz a uma série de atos violentos, revelando a deformidade de seu caráter e, consequentemente, sua monstruosidade moral. Assim, nessa narrativa, o

\footnotetext{
${ }^{5}$ GIL. 2006, P. 53 e 54.
} 
amor se revela como um sentimento dicotômico, capaz de despertar tanto o que há de melhor no ser humano, como a sua faceta bárbara e perversa.

Logo, com o propósito de compreendermos como as relações de amor e monstruosidade são retratadas no romance e, posteriormente, recriadas na dança, empreenderemos, neste capítulo, uma investigação das principais definições e conceitos de amor e monstruosidade, por meio de uma perspectiva filosófica,. Nesse contexto, os períodos de elaboração das obras e de desenvolvimento das tramas, do romance e do balé serão analisados com especial atenção.

\subsection{Do amor}

Embora o amor seja um tema universal, discutir sobre as suas concepções e nuances nunca é uma tarefa fácil. Ao receber um prêmio em 1989, o filósofo e pensador francês Paul Ricœur inicia seu discurso com a máxima: "falar de amor é muito fácil, e, ao mesmo tempo, muito difícil. Aquele que se engaja nessa empreitada corre o risco ou do exagero ou da banalidade." 6 Tal frase elucida com veemência as dificuldades encontradas por aqueles que se arriscam na árdua missão de refletir sobre um assunto indecifrável e fascinante como o amor. Essa complexidade se deve, em parte, ao seu carácter intrincado que, assim como os conceitos de Deus e de alma, por exemplo, representam um enigma perante o homem e as ciências.

No entanto, apesar das dificuldades inerentes, muitos foram os pensadores, filósofos e escritores que se arriscaram nessa empreitada. Dessa forma, ao longo dos séculos, surgiram diversos conceitos, interpretações e formas de representação desse sentimento. A vasta gama de concepções se justifica até mesmo pelo fato de o conceito de amor abarcar várias facetas e uma diversidade de sentidos. De acordo com Baladier,

O amor designa toda uma gama de relações e afetos que vão do desejo sexual e do erotismo às inclinações mais ou menos sublimes por pessoas, por valores e por condutas - inclinações e interesses que se exprimem nos sentimentos de carinho, ligação afetuosa, amizade e confiança mútua. $^{7}$

As múltiplas vertentes que abrangem o conceito de amor descrito por Baladier justificam o empenho de diversas áreas do conhecimento em estabelecer uma definição para esse vocábulo. É possível encontrarmos elucidações sobre o amor em domínios

\footnotetext{
${ }^{6}$ RICOEUR apud ACAPOVI, 2010, p. 100

${ }^{7}$ BALADIER; DAVID-MENARD; IOGNA-PRAT, LUCKEN. 2001, p. 133 e 134 (tradução nossa)
} 
como a antropologia, a sociologia, a biologia, a teologia e a psicanálise. Todavia, a primeira disciplina a se debruçar sob esse tema foi a filosofia.

Desde a Antiguidade, a filosofia tenta explicar a natureza do amor. Vários filósofos discutiram suas formas e metamorfoses. Na Grécia antiga, por exemplo, o amor era subdivido em três tipos, os quais correspondiam a três concepções distintas: eros, philia e ágape.

A primeira forma de amor, eros, pode ser entendida como o amor passional. Essa concepção de amor, na qual tal sentimento é associado ao desejo e à falta, é exposta por Platão, um dos primeiros pensadores refletir sobre a questão. Em sua obra O Banquete, escrita por volta de 380 a.C., observamos um rico diálogo a respeito do amor, o qual é denominado como Eros. Na narrativa, os participantes do banquete, dentre os quais estavam os principais filósofos do período, são convidados por Sócrates, após o exagero cometido na festa do dia anterior, a tentarem definir o que é o amor. Entre os pontos de vista elencados por cada convidado, destacam-se a definição de amor segundo Sócrates e o mito sobre a genealogia do amor exposto por Diotima de Mantineia.

Para Sócrates, aquele que deseja o amor deseja aquilo que não tem, aquilo de que é carente. Em outras palavras, Sócrates postula que só era possível amar aquilo que não se possuía. O objeto do amor sempre está ausente, mas sempre é solicitado. Sócrates ainda conclui que, estando o amor relacionado com aquilo que falta ao indivíduo, forçosamente ele não pode ser belo nem bom, visto que necessariamente o amor é amor do belo e do bom. O raciocínio apresentado por Sócrates nos induz a duas reflexões possíveis: ou amamos aquilo que não temos e, consequentemente, sofremos de amor, ou temos aquilo que teoricamente nos faltaria, entretanto não amamos mais. Não há como desejar aquilo que temos. Assim, o amor é sempre desejo e jamais possessão. Logo, essa concepção platônica exclui a possibilidade de ligarmos o amor à felicidade. Não existe amor feliz, uma vez que ser feliz significa obter aquilo que desejamos.

Nesse mesmo diálogo, a origem de Eros é narrada por Sócrates, que declara que os mistérios do amor lhe haviam sido revelados pela sacerdotisa Diotima de Mantineia. Ao ser indagada por Sócrates sobre a origem do amor, Diotima nos relata um mito. Segundo o mito, na ocasião do nascimento de Afrodite, houve uma grande festa no Olimpo, na qual se reuniram todos os deuses e deusas, exceto Penúria, a deusa da miséria. Todos os convidados estavam mais ou menos bêbados, quando Penúria 
adentrou a festa e aproveitou-se do estado vulnerável de Poro - o deus da Abundância. Após a consumação do ato sexual com Poro, Penúria engravida. O fruto desse breve relacionamento é Eros, o deus do amor. Devido a sua origem, Eros concilia em sua essência tanto a carência e a miséria de sua mãe Penúria, como a abundância e a prosperidade de seu pai Poro. De fato, o mito do nascimento do amor exposto por Sócrates é de suma importância para a teoria platônica, uma vez que ele ratifica a concepção de amor enquanto carência.

Por sua vez, Aristóteles recorre à palavra philia para definir o amor em sua obra Ética Nicomaquéia. Para ele, amor é alegria. O ser amado é a causa da felicidade do outro. Efetivamente, philia contrapõe o pensamento platônico, posto que não há uma carência na origem desse tipo de amor. Ao contrário, a philia é fruto de uma potência, de uma fonte que se regozija no compartilhamento e na troca. Essa forma de amor é caracterizada não somente pela afeição recíproca entre pais e filhos, mas também entre casais. No entanto, as relações de afeto entre homem e mulher são fundadas muito mais na amizade dos que nas relações passionais, tendo em vista que a sexualidade e a paixão cedem lugar ao entendimento tácito, à empatia e à reciprocidade. Portanto, é exatamente nesse ponto que philia distingue-se de eros. Em philia há carinho, reciprocidade e apreço pelo outro, ao passo que em eros o sentimento de ambição e possessão predominam.

Já o terceiro tipo de amor, o ágape, apesar de existir desde os gregos, ganha destaque somente mais tarde com o advento do Cristianismo. Ele provém da necessidade dos cristãos de usar um novo termo para falar do amor de Deus e de Jesus Cristo, visto que os termos philia e eros não abarcavam o sentido professado pelo Novo Testamento. De acordo com a visão cristã, os objetos dessa forma de amor seriam Deus, em primeiro lugar, e, em seguida, o próximo. Consequentemente, se Deus é amor, não haveria como compreendê-lo de acordo com a definição de eros, posto que Deus é onipresente e onipotente, não podendo ser a carência de algo. Assim, foi preciso encontrar um vocábulo que definisse o amor divino e espiritual em todas as suas injunções. De fato, o conceito de amor ágape é de suma importância, pois ele é um dos principais fatores constitutivos de nossa civilização atual.

Fortemente influenciada pelos valores e pela moral cristã, a Idade Média traz consigo algumas mudanças importantes em relação à Antiguidade, principalmente no que concerne a correlação entre o desejo e o prazer. Sabemos que os gregos não 
acreditavam na existência simultânea desses dois sentimentos. Para eles, ou desejamos algo e isso é doloroso, ou obtemos o prazer de conseguir o desejado. Entretanto, a escolástica promove uma reformulação desse ponto de vista ao estudar a aparição do desejo na consciência. Conforme a teologia medieval, o desejo é um movimento involuntário e espontâneo, "um movimento primeiro da sensualidade" 8 . Teoricamente, a tomada de consciência desse desejo obrigaria o homem a exercer uma escolha entre duas possíveis opções: ou o indivíduo apela para sua força de vontade e repele o desejo, uma vez que ele conduz a uma ação proibida, ou sucumbe à tentação. Todavia, os teólogos medievais passam a considerar a existência de uma terceira possibilidade: o desejo pode se prolongar sob a forma de conveniência. O sentimento suscitado por esse prolongamento já não receberia mais o nome de desejo, mas sim de prazer. Tal prazer foi denominado como delectatio morosa. De acordo com Baladier, "os teólogos cristãos introduzem o prazer entre o desejo de um objeto e a possessão deste. ${ }^{\circ} \mathrm{O}$ teórico afirma ainda que todas essas inovações correlacionadas ao desejo e ao prazer não interessam apenas aos moralistas e ao encarregado de ouvir confissões e atribuir punições aos pecadores. "Elas representam o destaque de uma atitude psíquica sob a qual se pode fundar um erótico inédito." ${ }^{\prime 10}$ É necessariamente sob essa nova atitude que se respalda o conceito de amor medieval que expresso na literatura desse período.

[...] a invenção do amor nos séculos XII e XIII no Ocidente, apoiar-se-ia, primeiramente, sob uma descoberta psicológica prévia, a delectatio morosa do teólogos moralistas, ou seja, na volúpia fantasma de desejar, no prazer próprio à imaginação concupiscente; experiência ora deliciosa ora difícil sob a qual os poetas cortês fundam sua original erótica. ${ }^{11}$

O amor cortês, característico da literatura medieval, apresenta um jogo de regras claras e definidas, que promovem uma ordem específica, a qual denota ao triângulo amoroso - jovem, dama e senhor - e a uma hierarquia de poder social. Esse tipo de amor, fortemente influenciado pela filosofia cristã, era pedagógico e civilizador, uma vez que se baseava na crença de que o único lugar plausível para a realização do amor o ato sexual - era o casamento. A tradição lírica trovadoresca, responsável por cantar esse amor cortês pautado no distanciamento entre o homem e a mulher, regozijava-se,

\footnotetext{
${ }^{8}$ BALADIER, DAVID-MENARD, IOGNA-PRAT, LUCKEN. p. 138 (tradução nossa)

${ }^{9}$ Idem, p. 138

${ }^{10}$ Idem, p. 141

${ }^{11}$ Idem, p. 143 e 144
} 
segundo Baladier, na imaginação e no desejo do ser amado, ou seja, na delectatio morosa.

No entanto, sabemos que durante a Idade Média, concomitantemente ao amor cortês, havia a paixão carnal. Devido ao fato de contrariar os preceitos e os dogmas da Igreja, esse tipo de amor é retratado, principalmente nas obras literárias do período, como sinônimo de dor, sofrimento e morte. Em Tristão e Isolda, por exemplo, é possível observamos tanto a presença dessa paixão carnal quanto do amor cortês. Tal dicotomia, analisada sob a ótica da filosofia cristã predominante, visava demonstrar que o amor que se encerra ao casamento é mais valioso que aquele que se finda nas pulsões da paixão.

Compreender como os estudiosos entendiam o amor na Idade Média e como, por sua vez, a literatura o retratava se faz necessário, visto que as narrativas, tanto do romance hugoano quanto do balé Notre-Dame de Paris, desenvolvem-se nesse período. Embora o criador de cada uma das obras acrescente elementos e percepções concernentes ao momento histórico de suas concepções, existem conceitos próprios à Idade Média que ecoam em ambas as narrativas. A título de exemplo, podemos evocar a noção de que a paixão carnal conduz ao sofrimento, retratada nas duas obras. No romance hugoano, o personagem de Claude Frollo alimenta um desejo perverso por Esmeralda. A impossibilidade de realização dessa paixão devido aos seus votos clericais associada à rejeição da cigana provoca um tormento em sua alma. Entretanto, esse sofrimento não se restringe ao padre. Inconformado com o desprezo de Esmeralda, Claude Frollo pratica uma série de violências contra a dançarina, que culminam com a morte de Esmeralda. Por sua vez, Roland Petit afirmou, em diversas ocasiões, que sua ideia ao recriar Notre-Dame de Paris para a dança era contar uma história de amor e de morte. Sua narrativa coreográfica se concentra exatamente no elemento trágico, provocado por desejos e paixões proibidas.

Outra característica advinda desse mesmo momento histórico e representada em ambas narrativas é a culpabilidade experimentada por Frollo causada pelo seu desejo incontrolável por Esmeralda. A partir do instante em que a Escolástica considera a possibilidade de haver prazer no desejo, há concomitantemente uma mudança na ideia de pecado. Uma vez que há prazer preliminar no ato sexual, ou seja, no desejo em si, tal desejo é também considerado como um ato pecaminoso. A consciência de Claude Frollo sobre esse fato - especialmente por ele ser um padre - associada à paixão desenfreada 
que alimenta por Esmeralda provoca um tormento em sua alma, o qual o conduz à pratica de atos violentos contra a jovem cigana, tornando-o, consequentemente, um monstro moral.

O espírito racionalista do Iluminismo também trouxe contribuições importantes para a concepção de amor e, por conseguinte, para o campo literário. De fato, os ideais advindos dessa corrente filosófica influenciaram tanto Victor Hugo quanto seus contemporâneos pertencentes à estética romântica no século XIX. Enquanto a Idade Média retoma a teoria platônica de eros, complementando-a com o elemento ágape, o Século das Luzes analisa o amor do ponto de vista do sujeito racional, excluindo a perspectiva do amor divino. Em sua obra As paixões da Alma, René Descartes define o conceito de amor baseado somente em seu aspecto psicológico e biológico, não levando em consideração o aspecto metafísico atribuído pela tradição até então a esse sentimento. Para Descartes, "não existe melhor forma para chegar ao conhecimento de nossas paixões do que examinar a diferença que há entre a alma e o corpo, a fim de saber a qual dos dois se deve atribuir cada uma das funções existentes em nós."12 Descartes afirmava que a natureza humana era composta por duas naturezas distintas, a natureza da alma e a natureza do corpo. Apesar de essencialmente diferentes, essas naturezas estavam de fato unidas, posto que o homem é composto do resultado da junção desses dois elementos. É sob essa perspectiva que o filósofo estabelece sua definição sobre o amor.

De acordo com Descartes, existem dois tipos de amor: o amor racional, o qual não implica o corpo, e o amor paixão, fundado na união de corpo e alma. $\mathrm{O}$ amor racional é definido como "uma emoção da alma causada pelo movimento dos espíritos que a incita a unir-se voluntariamente aos objetos que lhe parecem convenientes." ${ }^{13}$ Ele é uma das seis paixões primitivas enumeradas por Descartes, das quais as outras todas são apenas ramificações apresentadas pela mistura das seis paixões fundamentais. Por sua vez, o amor paixão é definido como "um pensamento confuso provocado na alma por algum movimento dos nervos, pensamento que a dispõe a este outro pensamento mais claro em que consiste o amor racional." ${ }^{14}$ Assim, segundo Descartes, é possível pensar a paixão como repercussões de certas emoções fisiológicas na alma, ou seja, a paixão movimenta o corpo e dá sinais de sua presença. Essa intrínseca relação entre o

\footnotetext{
${ }^{12}$ DESCARTES. 1979,. p. 217

${ }^{13}$ ACAPOVI, 2010,. p. 28

${ }^{14}$ DESCARTES, 1979,. p. 227
} 
corpo e a alma é justamente a razão pela qual o controle da paixão não se dá por meio da vontade. De fato, a vontade nada pode contra a paixão que é acompanhada da emoção que a fortalece. "De todas as espécies de pensamentos que ela [a alma] pode ter, não há outros que a agitem e a abalem tão fortemente como essas paixões."15 Portanto, a paixão pode ser entendida como um poderoso estado intelectual e afetivo capaz de dominar a alma de um indivíduo devido à intensidade de seus efeitos.

A partir dos preceitos elaborados por Descartes, é possível entender como o Iluminismo influenciou diretamente o Romantismo no século XIX, principalmente no que concerne a representação do amor e de seus efeitos. De acordo com Barreto, "no interior do movimento romântico uma paixão excessiva ou uma energia exagerada pode tornar-se uma ameaça potencial ou uma via de crime. Formas violentas de amor podem surgir do encontro da beleza e de personalidades criminosas."

Símbolo da estética romântica francesa, Victor Hugo concebe Notre-Dame de Paris exatamente sob essa ótica. A trama de sua narrativa se desenvolve a partir dos vínculos afetivos estabelecidos pelos personagens e sua relação com a monstruosidade. Embora esses vínculos afetivos figurem em diferentes tipos e graus de intensidade na obra, eles enunciam, em parte, não apenas o caráter dos personagens, como também o pensamento filosófico em voga no período. Para Victor, o amor é um conceito dicotômico, que poderia se revelar tanto como uma força positiva, capaz de expor o que há de mais humano no homem, quanto uma potência negativa, suscetível a conduzir o indivíduo à prática de atos violentos.

Embora concebida no século XX, a obra de Roland Petit traz à tona os mesmos preceitos hugoanos em relação ao amor. Destacando o viés trágico do texto de Victor Hugo, a narrativa coreográfica de Petit demonstra como o amor pode revelar a bondade e a humanidade de Quasimodo, assim como o desejo introduziria a desordem e a confusão dos pensamentos, conduzindo Claude Frollo e Esmeralda a um destino fatal.

Assim, ao traçarmos esse percurso pelos diversos conceitos e definições de amor, é possível identificarmos os tipos de afetos distintos que permeiam as narrativas, a saber: o amor incondicional de Quasimodo por Esmeralda (entendido, de acordo com a perspectiva da Antiguidade, como um amor philia), a paixão perversa de Claude Frollo (analisada a partir da perspectiva de paixão proposta por Descartes), o interesse

\footnotetext{
${ }^{15}$ DESCARTES, 1979. p. 232

${ }^{16}$ BARRETO, 2006. p. 291
} 
carnal e passageiro de Phœbus e o afeto de Gringoire pela dançarina (presente somente no romance).

\subsection{Do monstro}

Desde a Antiguidade, os monstros sempre estiveram presentes no imaginário popular de diversas civilizações e culturas, despertando, ao mesmo tempo, horror e fascínio, e levando o homem a questionar-se a respeito de sua própria humanidade. Por essa razão, esses seres geralmente são motes para inúmeras estórias, lendas, romances, filmes e, até mesmo, para a dança. Mas, afinal, o que é um monstro?

Ao longo dos séculos, inúmeros estudiosos tem se dedicado à árdua tarefa de tentar responder a esse questionamento, gerando diversos conceitos e noções quanto à monstruosidade. Assim, neste capítulo teceremos um breve histórico sobre as possíveis definições e origens dessa palavra, assim como realizaremos um mapeamento dos seres denominados como "monstros" na obra hugoana e na narrativa coreográfica de Roland Petit.

A primeira ideia que devemos ter em mente ao estudarmos a monstruosidade é a de que esse conceito é mutável, pois ele varia de acordo com o pensamento, a cultura, o período e, principalmente, a norma vigente em determinada civilização. Assim sendo, não há apenas uma definição de monstro. Ao contrário, existem algumas tentativas de definição, as quais mudam conforme a época e o autor. A noção de monstruosidade está intimamente relacionada à norma, e modifica-se de acordo com ela. Segundo Claude Kappler,

Em sentindo mais geral, o monstro é definido em relação à norma, sendo este um postulado do senso comum; o pensamento não atribui facilmente ao monstro uma existência em si, que é espontaneamente atribuída à norma. ${ }^{17}$

Logo, o conceito de monstro e monstruosidade são frutos de uma construção cultural, a qual depende da norma em voga. Essa mesma ideia é retomada por outros autores, entre eles Jeffrey Cohen, que afirma que o corpo do monstro é um corpo cultural. Para esse estudioso, o monstro pode ser concebido como a corporificação de um dado momento cultural.

O monstro nasce nessas encruzilhadas metafóricas, como a corporificação de um certo momento cultural - de uma

\footnotetext{
${ }^{17}$ KAPPLER, 1994. p. 291
} 
época, de um sentimento e de um lugar. $\mathrm{O}$ corpo do monstro incorpora - de modo bastante literal - medo, desejo, ansiedade e fantasia (ataráxica ou incendiária) dando-lhes uma vida e uma estranha independência. $\mathrm{O}$ corpo monstruoso é pura cultura. ${ }^{18}$

Assim, a fim de melhor compreendermos como esses conceitos se modificaram ao longo do tempo, assumindo sentidos diferentes, realizaremos um pequeno percurso pelos principais estudiosos do tema. Tendo em vista que nosso trabalho visa uma análise do amor e da monstruosidade nas obras de Victor Hugo e Roland Petit, não empreenderemos uma discussão exaustiva a respeito desse objeto de estudo. Nosso objetivo concentrar-se-á em elaborar um breve panorama sobre as definições de monstro e monstruosidade, com a intenção de, em um segundo momento, embasarmos nossa contenda. Ademais, é importante salientarmos que os autores eleitos para fundamentar nossas ideias são simples exemplares em vasto campo de estudiosos, não buscamos aqui demonstrarmos uma suposta evolução do conceito de monstruosidade.

Como postulado anteriormente, os monstros sempre exerceram um fascínio sob a humanidade e, desde a Antiguidade, foram objeto de estudo de diversos autores. Entre os primeiros estudiosos a consagrar uma reflexão científica a respeito desse tema está Aristóteles. Esse pensador grego possuía uma noção de monstruosidade ampla e relativizada. Para ele, a principal característica do monstro é a diferença face à "generalidade dos casos" "19. Em outras palavras, para Aristóteles, tudo aquilo que fosse exceção em relação à norma poderia ser denominado como monstro. Logo, até mesmo uma criança que não fosse parecida com seu progenitor era considerada como monstruosa. Quanto maior a dessemelhança ao padrão, maior seria a imperfeição.

Embora Aristóteles alimentasse a crença de que havia inúmeros graus e modulações de monstruosidade, ele não via o monstro como motivo para questionar a ordem universal. Mesmo que houvesse seres em todos os níveis da criação que fugissem ao padrão, apresentando anomalias de diversas ordens, ele não acreditava que a natureza se enganasse, nenhuma de suas obras era fruto do acaso. Esse mesmo pensamento, de que não há erro por parte da natureza, é retomado por Santo Agostinho, no século VI d.C, em sua célebre obra Cidade de Deus. Como homem da Igreja, Santo agostinho não estava preocupado em estabelecer uma análise de cunho científico em sua obra. $\mathrm{Na}$ verdade, seu objetivo era reconduzir para o bom caminho o fiel que dele tivesse se

\footnotetext{
${ }^{18}$ COHEN, 2000. p. 26 e 27.

${ }^{19}$ ARISTÓTELES apud COHEN. p. 294
} 
afastado, uma vez que a monstruosidade representava um problema teológico para o devoto, pois poderia levar o devoto a questionar os desígnios divinos. "Aquele que, diante da monstruosidade, julga estar diante de um erro do Criador, demonstra ter espírito acanhado, pois, não vendo senão um aspecto limitadíssimo do universo, não pode perceber a razão daquilo que o choca." 20

Assim como Aristóteles, Santo Agostinho acreditava que a semelhança era o principal critério para a normalidade, logo os monstros seriam aqueles indivíduos que se diferenciam da norma. No entanto, Santo Agostinho tenta minimizar essa dessemelhança em seus estudos, visto que elas eram interpretadas como uma ameaça à veracidade da palavra de Deus. Assim sendo, a fim de tentar justificar a existência de seres monstruosos, ele explica a incompreensibilidade do nascimento monstruoso através da existência de raças fabulosas.

Porque razão quis Deus criar assim alguns povos, senão para que, nesses monstros que entre nós convém nasçam dos homens, acreditássemos ter errado a sua sabedoria, que modela a natureza humana? Portanto, não nos deve parecer absurdo que, da mesma forma como em um só povo existem alguns homens monstruosos, assim também na totalidade do gênero humano existam alguns povos monstruosos. $^{21}$

De acordo com esse pensamento, o monstro, que era considerado como exceção em nossa sociedade, passa a ter um correspondente no universo - em uma raça fabulosa -, o que justificaria aparentemente o absurdo dos nascimentos monstruosos, embora não os expliquem. Conforme afirma Gil, ao deduzir a existência dessas raças monstruosas, Santo Agostinho subtrai “ à raça de monstros o estatuto de realidade que, na tradição clássica, era realmente o seu, fazendo da sua existência algo de provável e de incompreensível, ele torna-a maravilhosa, ao mesmo tempo que a integra no sistema de representações que a Bíblia contemplava.” De fato, Santo Agostinho abre a porta à admiração perante as maravilhas incompreensíveis da Criação. No texto de Santo Agostinho, assim como na maioria dos autores da Idade Média, não encontramos uma definição exaustiva sobre o monstro, há apenas deduções. Efetivamente, os monstros eram apenas um detalhe, o que esses autores almejavam era uma reflexão a respeito de sua própria humanidade. $\mathrm{O}$ homem medieval precisava poder pensar-se como gênero real, um animal mortal e racional.

\footnotetext{
${ }^{20}$ KAPPLER, 1994. p. 296

${ }^{21}$ SANTO AGOSTINHO apud KAPPLER, 1994. p. 298
} 
A perspectiva teológica geral sob a qual Santo Agostinho analisa os fatos anuncia, de certo modo, a forma de pensar da Idade Média sobre a monstruosidade. Nesse período, observamos uma forte marca da tradição greco-latina, assim como, a partir dos séculos XII e XIII, uma grande influência do Oriente, principalmente da China. Logo, a atitude intelectual em relação à monstruosidade tem pouca propensão a renovar-se.

Dentre as várias obras que servem para delinear a monstruosidade na Idade Média, destacam-se os relatos de viagem. Entretanto, entre os viajantes, nenhum apresenta independência intelectual. Eles fazem, no máximo, pequenas correções e contribuições à tradição, que para eles continua sendo verdadeira. Segundo Gil, até o início do século XVI, acreditava-se na existência de povos monstruosos nas regiões extremas do mundo, principalmente na parte oriental. A crença na existência desses povos era difundida justamente por meio desses relatos de viagens, os quais eram compilados por alguns historiadores. Entre os principais nomes desse período estão Tomás de Cantimpré, Ambroise Paré e Mandeville. Como postulado, esses autores pouco diferem dos estudiosos da tradição clássica quanto à definição de monstro. Seus estudos apresentam contribuições mais significativas apenas no que concerne à interpretação do papel desempenhado pelos monstros no universo. De fato, segundo afirma Kappler, “a Idade Média está presa entre a necessidade de explicar a 'desordem' representada pelo monstro e a de crer no postulado de que a natureza, obra de Deus, só poderia ser perfeita e portanto organizada segundo uma disposição imperturbável." ${ }^{22}$

Durante grande parte da Idade Média, o critério para a monstruosidade continuou sendo a norma que, por sua vez, era entendida por esses autores como sinônimo da natureza. Em outras palavras, pode-se dizer que o monstro era aquele que contrariava o curso da natureza. Tal concepção parece adquirir novos contornos somente quando Tomás de Cantimpré utiliza a palavra razão no lugar de natureza para definir a monstruosidade. No entanto, é difícil compreender o sentido exato empregado em seu texto, uma vez que esse vocábulo apresentava uma série de acepções diferentes durante esse período, dentre as quais se infere a noção de ordem e justa medida, sendo seus contrários a desordem e o descomedimento. Assim, a partir desse pensamento, "o monstro, portanto, é uma manifestação de desordem. É desordem por carência ou por

${ }^{22}$ KAPPLER,1994. p. 360 
'superfluidade', sendo o critério a forma inicial, forma de homem, de animal ou de vegetal, forma perfeita tal qual Deus criou. Portanto, por natureza, é imperfeito."23

Além de ser considerado imperfeito, uma vez que não correspondia o padrão de perfeição da natureza, o monstro também era frequentemente associado como inimigo do belo. Durante a Idade Média, a feiura é considerada quase como um atributo obrigatório do monstro. Entretanto, em alguns casos, pode acontecer que o monstro se distinga pela beleza, sendo mais bonito que todas as bestas e animais do mundo. Portanto, a monstruosidade estaria situada nos extremos tanto do belo quanto do horrível. Ademais, outros autores consideram os monstros seres nocivos. Por sua vez, outros dizem que o monstro se distingue pela raridade. Em resumo, para os europeus, quase tudo que fosse diferente da norma seguida por eles era considerado monstruoso.

Outra questão importante para os autores medievais era a causa da monstruosidade. Toda uma tradição que vai até o século XVIII associava o nascimento monstruoso com a "podridão matriarcal" 24 . Havia uma relação direta entre nascimentos monstruosos e a devassidão ou corrupção matriarcal.

[..] a devassidão é uma das causas da existência dos monstros, acrescentando uma carga metafórica, como "sujidade moral", à "sujidade matriarcal" que alimenta o embrião. E isso provoca o nascimento do monstro. ${ }^{25}$

Na Idade Média, o monstro era entendido como um sinal divino, o qual precedia ou prefigurava um acontecimento, ou seja, de maneira geral, o monstro era concebido como um presságio de augúrio. De fato, a noção de aviso divino está na própria substância da palavra monstrum. A origem desse vocábulo remonta ao verbo latino monere, o qual originou duas palavras: monstrare (indicar ou mostrar) e monstrum (aviso). Na obra, Le vocabulaire des institutions indo-européennes, Benveniste afirma que a etimologia do vocábulo monstrum está relacionada ao sentido de moneo, advertir.

Se, portanto, de monstrare chegarmos a monstrum para encontrar o sentido literal, suprimido pela religião, verificamos que monstrum, deve ser entendido como um conselho, um advertência dada pelos deuses. Ora, os deuses exprimem-se através de prodígios, sinais que confundem o entendimento humano. Uma advertência

\footnotetext{
${ }^{23}$ KAPPLER, 1994, p. 308

${ }^{24}$ GIL, José. p. 85

${ }^{25}$ Idem, p. 85
} 
divina toma o aspecto de um objeto ou de um ser sobrenatural. ${ }^{26}$

Apesar da origem desse vocábulo nos remeter diretamente para a concepção de que os monstros são uma advertência divina, não há a plena certeza de que os autores medievais estivessem cientes das raízes dessa palavra, pois não existe nenhum estudo filológico a respeito dessa expressão em nenhuma obra deste período. No entanto, mesmo que tal consciência não existisse, é fato que durante toda a Idade Média, o monstro foi considerado um sinal premonitório, sendo material para diversas interpretações.

Até mesmo na literatura, o monstro ocupa um lugar privilegiado durante a Idade Média e nos tempos do Renascimento. Conforme Barreto elucida, Rabelais (14941553), "utilizando-se da ênfase e do exagero, cria seus gigantes Gargantua, Pantagruel e toda uma amálgama de monstros extraordinários que permeia suas narrativas. ${ }^{27} \mathrm{De}$ fato, o imaginário monstruoso constituído nesse período influencia não apenas as obras medievais, como também narrativas posteriores. Ambientada na Idade Média, a narrativa Notre-Dame de Paris traz como herói o sineiro Quasimodo, denominado como monstro pelos demais personagens devido a suas deformidades físicas. Quasimodo é considerado por todos como uma aberração da natureza. Embora humano, a sociedade de seu tempo não lhe confere esse "status", associando- o, frequentemente, a animais e monstros fantásticos. Logo, o conceito de monstro físico enquanto alteridade que fere a norma, apresentando deformações corpóreas, é mantido por Victor Hugo em seu romance.

No final da Idade Média, a noção de monstruosidade ganha novas conotações, pois ela passa a ser associada ao demoníaco. Influenciado pela mitologia oriental, o ocidente começa a atribuir às criaturas que até então não tinham uma natureza monstruosa bem definida em sua origem um caráter diabólico, ou seja, o monstruoso que até então pertencia à natureza do indivíduo passa a apresentar características novas. Durante esse período, por exemplo, o diabo se torna tema para diversas variações sobre seres monstruosos. O diabo é um monstro e, de modo, geral, a representação do mal passa obrigatoriamente por formas monstruosas.

O final da Idade Média traz consigo outra mudança importante em relação à monstruosidade. De acordo com Kappler,

\footnotetext{
${ }^{26}$ BENVENISTE, E. apud GIL. p.257

${ }^{27}$ BARRETO, 2006 p. 32
} 
[...] assistimos ao surgimento do monstro 'individual', datado, localizado, com pretensões à historicidade: esse monstro que 'fala' de realidades próximas, que condena e aprova circunstâncias presentes, que interpela um povo inteiro em nome de Deus (pelo menos essa é a opinião de quem explora politicamente seu aparecimento), tende a implantar-se no mundo de modo mais angustiante que o monstro 'cosmológico'. Este estava distante e era justificado por visões de mundo que o mantinham no seu lugar; no século XV, essa fronteiras vão ficando cada vez mais discretas, e o monstro, que realmente não está mais 'contido', irrompe na vida e na arte, na religião e na teologia. ${ }^{28}$

Logo, é possível perceber que, embora a Idade Média continue presa à tradição e não consiga responder aos seus próprios questionamentos referentes à monstruosidade, ela representa um período importante para a temática, uma vez que diversas visões de mundo surgem e coexistem pacificamente, possibilitando discussões mais aprofundadas sobre o assunto nos séculos posteriores.

O século XIX, por sua vez, traz consigo modificações importantes quanto à concepção de monstro. Mais precisamente, a partir do final do século XVIII, a monstruosidade passa a centrar-se no comportamento do indivíduo, ou seja, aqueles seres que apresentavam um desvio de carácter ou conduta também passaram a ser entendidos como seres monstruosos. Assim, o conceito de monstruosidade foi suplantado também para o domínio da criminalidade pura e simples. Consequentemente, surge a figura do monstro moral.

Segundo Foucault, a monstruosidade moral irrompe a partir do momento em que há um questionamento jurídico a respeito da natureza do criminoso.

O crime não é mais, portanto, apenas o que viola as leis civis e religiosas; o crime não é mais apenas o que viola eventualmente, através das leis civis e religiosa, as leis da própria natureza. O crime é agora o que tem uma natureza. Eis o crime, pelo jogo mesmo da nova economia do poder de punir, ei-lo lastreado de uma natureza. O crime tem uma natureza e o criminoso é um ser natural caracterizado, no próprio nível de sua natureza, por sua criminalidade. ${ }^{29}$

Logo, passa-se a acreditar que aqueles indivíduos que apresentassem um desvio de conduta, ou seja, fosse um criminoso, poderiam a vir a ser um monstro. Portanto, a palavra monstro adquire além do sentido usual, uma conotação figurada. De acordo com

\footnotetext{
${ }^{28}$ KAPPLER. 1994, p. 348 e 349

${ }^{29}$ FOUCAULT. 2013. p. 76
} 
Barreto, durante o século XIX, período em que Victor Hugo vive e escreve suas obras, o conceito de monstro se aplica tanto ao sujeito que apresenta anomalias físicas, quanto àquele ser que demonstra um carácter cruel e perverso, que é contrário às normas habituais, infringindo as leis da sociedade em busca de sua satisfação pessoal. É sob essa perspectiva que Claude Frollo é entendido como um monstro. O desejo descontrolado que ele sente por Esmeralda se transforma em uma obsessão, uma potência negativa que o leva a cometer diversos atos violentos a fim de possuir a cigana a qualquer custo. Entre as diversas ações criminosas praticadas pelo padre na tentativa de satisfazer seu desejo estão a tentativa de sequestro de Esmeralda, o golpe de punhal desferido contra Phœbus, a acusação proferida contra a cigana por esse crime e, ainda, o retirada de Esmeralda da Catedral - local de asilo - que culmina com a captura da personagem por parte das autoridades e a sua morte.

Por fim, durante o século XX, observa-se uma nova concepção em relação ao monstro teratológico. Com o avanço da ciência e da medicina, os seres portadores de más-formações passam a ser tratados como casos médicos. Consequentemente, a teratologia deixa de ser considerada como forma de monstruosidade e torna-se objeto de pesquisas médica e tratamento. Por outro lado, observa-se uma banalização da figura monstruosa. O aumento da violência assim como dos crimes com requintes de crueldade fez com que o monstro, sob as mais diversas formas, tornasse-se uma realidade cotidiana. Como afirma Barreto, "a proliferação de monstros de todos os tipos nos mais diversos domínios testemunha a atração sem fronteiras que eles exercem e, ao mesmo tempo, revela a dúvida do homem contemporâneo quanto à sua própria humanidade". ${ }^{30}$

Efetivamente, o monstro, nas mais diversas épocas, sempre representou esse ponto de interrogação para o homem. Em grande parte dos autores e das obras estudadas o conceito de monstro está ligado a um questionamento, seja ele de até que ponto o homem se afirma como homem, ou ainda, um questionamento das leis civis, religiosas ou divinas. A figura do monstro sempre levou a humanidade a refletir não apenas sobre si mesma, como também sobre a existência divina, o bem e o mal, entre outros. No entanto, nem sempre o homem encontrou respostas para todas essas questões.

Essas reflexões suscitadas pelo monstro nos conduzem para um caminho que inicialmente não nos parece tão óbvio: o homem se define em oposição ao monstro. De

${ }^{30}$ BARRETO. 2006. p. 36 
acordo com Gil, o monstro humano existe para que o homem possa construir uma ideia estável de si próprio e de sua humanidade.

Provavelmente o homem só produz monstros por uma única razão: poder pensar na sua própria humanidade. Seria possível traçar a história das diferentes ideias ou definições que o homem deu a si próprio através das diversas representações da monstruosidade humana que o acompanharam. ${ }^{31}$

O fato de monstro estar situado no limite da humanidade sempre fez de sua figura monstruosa um atrativo, pois não sabemos, ao certo, qual é o limite da linha tênue que separa nossa identidade humana da monstruosa. Consequentemente, ao mesmo tempo em que o monstro desperta o horror devido às suas deformidades físicas e morais, ele nos fascina. Ainda segundo Gil, o monstro atrai o homem, visto que "o nascimento monstruoso mostraria como potencialmente a humanidade do homem, configurada no corpo normal, contém o germe da sua inumanidade." ${ }^{, 32}$ Esse movimento simultâneo de repulsão e atração, provocados pelo monstro, pode ser visto, em parte, como uma das explicações para a sua grande popularidade.

Ao realizarmos todo esse percurso pelos variados conceitos e reflexões sobre a monstruosidade, podemos perceber que o monstro representa, ao mesmo tempo, multiplicidade, mistura, questionamentos, multiformes, diferença, etc. No entanto, independente do ponto de analisado, podemos concluir que o monstro é, em si, uma transgressão das normas, sejam elas naturais, sociais ou comportamentais. Logo, eles nos exigem uma reavaliação de todos nossos pressupostos, sejam eles culturais sobre raça, gênero, sexualidade; e ainda coloca em cheque nossa percepção da diferença e nossa tolerância quanto à sua expressão.

\footnotetext{
${ }^{31}$ GIL. José. p. 53 e 54.

${ }^{32}$ GIL. José. p. 125.
} 


\section{CAPÍTULO II}

\section{Narrativa textual: dizer e contar através de palavras}

Consagrado como um dos maiores autores de todos os tempos, Victor Hugo concebeu inúmeros romances e personagens que, ainda hoje, mais de dois séculos após seu nascimento, permeiam o imaginário popular e inspiram recriações de todos os gêneros.

Com o romance Notre-Dame de Paris, publicado pela primeira vez em 1831, não foi diferente. O trágico enredo da jovem cigana Esmeralda vítima do desejo que desperta em três homens serviu como mote para diversas transposições para outras artes, tornando-se um dos romances hugoanos com o maior número de recriações.

De fato, a difusão da obra de Victor Hugo por outros meios parece atender o desejo do próprio autor, o qual reconhecia a necessidade de difundir as obras literárias, de forma a torná-las acessíveis ao grande público. Assim, a tradução de Notre-Dame de Paris para outros códigos assegura não somente a propagação como a posteridade da obra hugoana ao longo dos tempos, dando-lhe nova vida a cada recriação.

O sucesso e a grande quantidade de adaptações desse romance podem ser justificados pelo fato de Notre-Dame de Paris ser uma narrativa propícia à encenação. A dramaticidade da história aliada à escrita metafórica concebida por Hugo tornam possível ilustrá-la e concretizá-la em outros meios artísticos, inclusive na dança. De acordo com Laroche,

\footnotetext{
A escritura de Victor Hugo é carregada por uma onda de figuras de estilo, sendo as mais frequentes as metáforas e as comparações, as quais estabelecem uma analogia, uma correspondência de formas e de movimentos, uma figura geométrica que pode ajudar o coreógrafo a materializar e a concretizar sua própria escritura que é a dança. ${ }^{33}$
}

Logo, neste capítulo, buscaremos compreender como as relações de amor e monstruosidade são configuradas no romance, investigando de que forma elas contribuem para a escritura da narrativa coreográfica.

\subsection{A construção dos personagens}

Símbolo da geração romântica do século XIX, Victor Hugo foi um dos grandes nomes desse período a desenvolver a tradição do romance histórico na França.

\footnotetext{
${ }^{33}$ LAROCHE. 1993, p.236
} 
Ambientada na cidade de Paris, no ano de 1482, a narrativa de Notre-Dame de Paris pode ser considerada como uma das principais obras desse gênero, reconstituindo ficcionalmente um dado momento do passado, que resgata a mentalidade e o comportamento do período por meio de uma narrativa, na qual personagens e personalidades históricas ai figuram e coexistem.

Escrito do ponto de vista de um narrador onisciente, o qual intervém na narrativa diretamente por meio de digressões, o romance traz como principal personagem a célebre catedral parisiense, construída sob os moldes da arquitetura gótica. A intriga desenvolve-se em torno desse monumento, o qual adquire um valor simbólico no romance tanto por refletir a multiplicidade e a diversidade da sociedade parisiense medieval, como por representar a transição entre dois períodos históricos e suas transformações marcados sobretudo pelo advento da imprensa ${ }^{34}$. De fato, a descrição realizada por Hugo confere a Notre-Dame uma dimensão fantástica, tornando-a um dos emblemas do autor na guerra contra os demolidores do patrimônio arquitetônico durante o século XIX.

A luta em prol da salvação dos monumentos medievais transfigura-se, ainda nesse romance, por meio de capítulos como Vol d'oiseau, no qual o autor realiza uma descrição detalhada da cidade de Paris durante o século XV, relatando sua riqueza e importância histórica. Assim, é sob essa Paris medieval e sua sociedade que Victor Hugo desenvolve seu enredo permeado de personagens contrastantes que variam desde pedintes e ciganos ao rei, o clero e à nobreza.

Apesar da diversidade e do grande número de personagens - aproximadamente trinta -, a trama amorosa do romance gira em torno da figura feminina Esmeralda, cigana e dançarina, pivô de diferentes formas de amor, a saber: o desejo perverso de Frollo, o interesse carnal e passageiro de Phœbus, o afeto fraternal de Gringoire (o qual não figura na narrativa coreográfica) e o amor devotado de Quasimodo.

É a partir desses personagens e das relações estabelecidas entre eles que Victor Hugo expõe as grandes linhas de Notre-Dame de Paris. Assim, com a intenção de entendermos como se estabelecem estes laços e alguns de seus possíveis significados, abordaremos, em primeiro momento, como esses personagens são retratados no romance, para então empreendermos uma análise de suas relações.

\footnotetext{
${ }^{34}$ No capítulo Ceci tuera Cela, Victor Hugo afirma por diversas vezes que o surgimento da imprensa marcaria o fim de uma era, na qual a arquitetura era um dos grandes meio de propagação dos pensamentos e da História da humanidade.
} 


\subsubsection{Quasimodo}

Abandonado com aproximadamente quatro anos de idade devido às suas deformidades físicas, Quasimodo fora encontrado pelo padre Claude Frollo no primeiro domingo após a Páscoa. Movido pela compaixão e pela piedade que aquele ser lhe despertara, Frollo decide adotá-lo, levando-o consigo para Notre-Dame. Com efeito, aquela era a segunda vez que o padre tomava uma criança aos seus cuidados. Aos 19 anos, após a morte repentina de seus pais devido a uma peste na cidade de Paris, Frollo torna-se responsável por seu irmão caçula Jehan, o qual lhe revela um amor até então desconhecido. Os cuidados com este irmão conduzem Frollo a realizar a adoção de Quasimodo, pois de acordo com ele, tal atitude funcionaria como uma espécie de depósito no céu, um investimento em boas ações para amenizar os pecados que um dia o irmão viesse a cometer. Assim, Frollo recolhe aquele ser disforme rejeitado tanto pela família quanto pela sociedade e batiza-o de Quasimodo.

A escolha desse nome não é feita ao acaso. De acordo com a tradição cristã, o primeiro domingo após a Páscoa é designado como "domingo de Quasimodo" ou simplesmente, Quasimodo. Essa denominação provém das primeiras palavras proferidas - em latim - durante a missa celebrada neste dia: Quasimodo genti infantes. Conforme Barreto explica, essa expressão entoada durante a entrada dos responsáveis pela celebração significava“ criança recém-nascida", ou ainda, "aquele que ainda tem muito a descobrir" 35 . Consequentemente, o nome atribuído a Quasimodo poderia ser interpretado como uma menção ao dia em que fora encontrado por Claude Frollo. Todavia, segundo afirma Barreto, pode-se inferir, ainda, um segundo significado para o nome do personagem. "Quasimodo é um quasi modo. Em latim quasi quer dizer quase e modo, de modus, significa forma, maneira, medida. Logo, a ideia deste nome nos remete a algo incompleto, ou seja, um quase homem,36

Portanto, o nome escolhido por Victor Hugo para este personagem traz em sua essência uma ambiguidade, podendo remeter tanto ao dia em que o sineiro de NotreDame fora encontrado, quanto à incompletude de Quasimodo.

Ainda de acordo com Barreto, "Quasimodo é apresentado como um caso teratológico, tendo em vista o carácter hibrido e berrante de sua monstruosidade, a

\footnotetext{
${ }^{35}$ BARRETO. 2006, p. 89

${ }^{36}$ Idem, p. 89
} 
mistura de formas humanas e animais que o compõe." ${ }^{37 .}$ Desde o seu nascimento, Quasimodo é comparado a um animal. Suas deformações físicas despertavam, ao mesmo tempo, horror e fascínio nos demais. No livro IV, por exemplo, Hugo descreve o diálogo empreendido entre quatro senhoras da sociedade, as quais observavam o pequeno ser disforme na armação de leito chumbada no adro da Catedral, onde se lia "crianças enjeitadas". As quatro respeitosas senhoras observam atônitas Quasimodo, enquanto discutiam a respeito de sua natureza. "Isso não é uma criança"38, dizia Agnès. “É uma macaco deficiente”,39 ${ }^{, 3 e t r u c a v a ~ G a u c h e ̀ r e . ~}$

É importante ressaltar que durante a Idade Média, período em que se desenvolve a trama, a monstruosidade estava diretamente associada às más-formações físicas. Tudo aquilo que apresentava um desvio em relação ao considerado o padrão estético estabelecido, era categorizado como um monstro físico. Com Quasimodo não foi diferente. Durante toda a narrativa, são empregadas diversas metáforas e adjetivos que o associam ao monstro e ao mal.

Essas comparações a um ser bestial e monstruoso são ratificadas pela própria descrição inicial realizada por Victor Hugo no momento em que o personagem é eleito Papa dos Loucos.

\begin{abstract}
Não tentaremos dar ao leitor uma ideia deste nariz tetraedro, desta boca em forma de ferradura, deste pequeno olho esquerdo obstruído por uma sobrancelha ruiva em tufos, ao passo que o olho direito desaparecia inteiramente sobre uma enorme verruga, destes dentes desordenados, gastos aqui e ali, como as seteiras de uma fortaleza, deste lábio caloso sobre o qual um desses dentes estendia-se como a defesa de um elefante; deste queixo bifurcado, e, sobretudo da fisionomia distribuída sobre tudo isso, desta mistura de malícia, espanto e tristeza. Que sonhemos, se possível, esse conjunto."
\end{abstract}

Zarolho, coxo e corcunda: eis a primeira descrição de Quasimodo. No entanto, essas não eram suas únicas deficiências. Após ser adotado, Quasimodo é levado para a catedral de Notre-Dame, onde é criado por Claude Frollo. O padre lhe ensina a ler e a escrever, e Quasimodo torna-se o sineiro da catedral. No entanto, seu ofício provoca-lhe

\footnotetext{
${ }^{37}$ BARRETO, 2006. p. 90

${ }^{38}$ HUGO, 2009. p. 236

${ }^{39}$ Idem, p. 236

${ }^{40}$ Idem, p. 47 e 48

Texto fonte: Nous n'essaierons pas de donner au lecteur une idée de ce nez tétraèdre, de cette bouche en fer à cheval, de ce petit ail gauche obstrué d'un sourcil roux en broussailles tandis que l'œil droit disparaissait entièrement sous une énorme verrue, de ces dents désordonnées, ébréchées çà et là, comme les créneaux d'une forteresse, de cette lèvre calleuse sur laquelle une de ces dents empiétait comme la défense d'un éléphant, de ce menton fourchu, et surtout de la physionomie répandue sur tout cela, de ce mélange de malice, d'étonnement et de tristesse. Qu'on rêve, si l'on peut, cet ensemble
} 
o rompimento dos tímpanos, tornando-o surdo. Tal surdez faz com que Quasimodo desenvolva uma dificuldade em comunicar-se com os demais, sendo capaz de emitir apenas sons guturais de difícil compreensão. Esses problemas em se expressar, aliados a suas más-formações congênitas, fazem de Quasimodo um ser melancólico e solitário.

Esse sentimento de exclusão é ratificado pelo tratamento da sociedade para com ele. Dos homens, Quasimodo conheceu apenas a raiva, o ódio e o desprezo. Quando estes lhe dirigiam a palavra, era apenas para maldizê-lo. Essas constantes agressões fazem com que Quasimodo aprenda a odiar a sociedade que o maltratava e o humilhava. Conforme Hugo afirma "ele odiava o povo por se sentir odiado."

O menosprezo enfrentado por Quasimodo provoca o seu isolamento em NotreDame. Esse espaço era para ele mais do que uma simples moradia, era seu universo, seu abrigo, seu esconderijo, algo sem o qual ele não sobreviveria. O confinamento desse personagem durante anos a fio nesse local, faz com que Quasimodo torne-se parte integrante desta "vasta sinfonia de pedra"42. A catedral fazia parte de Quasimodo - " a áspera catedral era sua carapaça"43-, e Quasimodo fazia parte da catedral.

\section{É assim que, pouco a pouco, desenvolvendo-se sempre no sentido da catedral, vivendo nela, dormindo nela, saindo dela quase nunca, sofrendo a toda hora sua pressão misteriosa, ele chegou a parecer com ela, a incrustar-se com ela, por assim dizer, a fazer parte integral dela. ${ }^{44}$}

Era em meio às estátuas e às gárgulas de Notre-Dame que Quasimodo se sentia reconfortado. Esses seres de pedra eram os únicos que não o menosprezavam, pois eram iguais a ele em relação à feiura e, consequentemente, à monstruosidade.

Embora Quasimodo seja denominado como monstro em virtude de sua aparência horrenda, percebemos, no decorrer da narrativa, que este ser disforme é, na verdade, dotado de sensibilidade e inteligência, características que se tornam visíveis, principalmente, por meio de seu amor e devoção por Esmeralda. De fato, as atitudes de Quasimodo ao longo da trama revelam que o sineiro possuía uma alma boa e generosa, a qual jazia presa em seu corpo defeituoso. Essa dualidade em sua essência permite ao leitor depreender quem, efetivamente, são os reais monstros da narrativa hugoana, visto

\footnotetext{
${ }^{41}$ HUGO, 2009. p. 145

${ }^{42}$ Idem, p. 156

${ }^{43}$ Idem, p. 247

${ }^{44}$ Idem, p. 247

Texto fonte: C'est ainsi que peu à peu, se développant toujours dans le sens de la cathédrale, y vivant, y dormant, n'en sortant presque jamais, en subissant à toute heure la pression mystérieuse, il arriva à lui ressembler, à s'y incruster, pour ainsi dire, à en faire partie intégrante.
} 
que, por baixo da carapaça feia e deformada de Quasimodo, era possível entrever a beleza e a sensibilidade existentes em seu espírito.

Ao recriar a obra de Hugo para a dança, Roland Petit procura ressaltar essa dualidade presente em Quasimodo. No entanto, segundo afirma o coreógrafo, seu "Quasimodo não é um monstro, ele está mais para um sujeito complexado, pois ele sofreu um acidente. Ele é um ser rejeitado por sua diferença." ${ }^{45}$ Pode-se notar que, efetivamente, Roland Petit concentra sua narrativa naquilo que ele considera o mais importante do romance hugoano: a rejeição e a humilhação sofridas por Quasimodo. Isso fica evidente em diversas sequências ${ }^{46}$ de sua coreografia. A título de exemplo, podemos citar o primeiro quadro do balé, em que o sineiro de Notre-Dame é eleito Papa dos Loucos. Apesar de ser evidente a deformidade do corpo de Quasimodo ao surgir em cena, ele não é apresentado ao público como um ser monstruoso que aterroriza a todos. A expressão de medo e ternura no rosto do bailarino aliada aos seus movimentos desajeitados, porém delicados, revelam desde o primeiro momento a ambiguidade deste personagem.

No momento da aparição de Quasimodo em cena é interessante notar que o corpo de baile permanece imóvel em um primeiro momento, como que fascinados pelo sineiro. Todavia, logo em seguida, eles o cercam, com gestos pantomímicos, apontandolhe o dedo e rindo de sua horrenda figura. Quasimodo logo se torna agressivo. Essa sequência ratifica a prerrogativa hugoana de que o mau comportamento de Quasimodo ocorre em virtude do escárnio e das humilhações que ele sofre da sociedade.

\footnotetext{
${ }^{45}$ FIETTE, 2007, p. 24

${ }^{46}$ Ao escrever o livreto de Notre-Dame de Paris, Roland Petit divide o balé em dois atos e treze quadros. Esses, por sua vez, subdividem-se em sequências, que ao todo totalizam 28.
} 


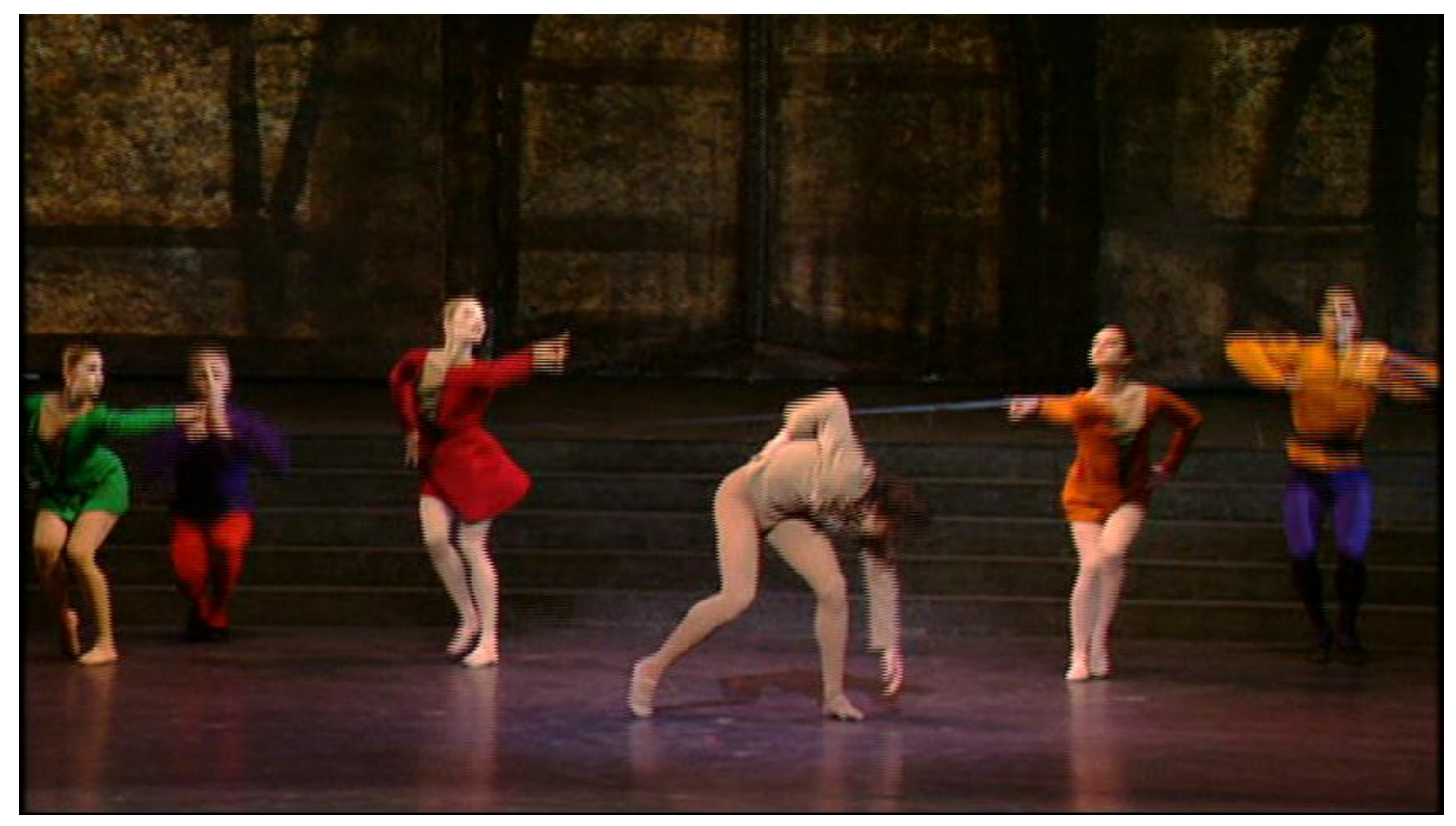

Figura 1 - Quasimodo por Nicolas Le Riche, em Notre-Dame de Paris, 1996

\subsubsection{Claude Frollo}

Tanto no romance de Hugo quanto no balé, Frollo nos é apresentado como um homem frio e sombrio. No entanto, enquanto no balé pouco se sabe a respeito de sua origem e de sua trajetória; no romance a vida de Claude Frollo nos é exposta em detalhes.

Filho de senhores da alta burguesia, Claude Frollo fora destinado desde sua tenra infância ao celibato. Quando criança fora mandado por seus pais para um colégio interno, onde aprendeu alguns dos requisitos necessários à vida clerical. Todavia, o enclausuramento da escola faz de Frollo uma criança triste e antissocial.

Durante esse período Claude dedica-se avidamente aos estudos. Aos 18 anos, ele havia concluído as faculdades de Teologia, Direito, Medicina e de artes liberais. "Parecia que, para aquele jovem homem, a vida possuía um único objetivo: saber."47 Entretanto, após uma peste devastadora na cidade de Paris a qual mata seus pais, Frollo que até então não havia amado nada além dos livros, vê-se obrigado a tomar aos seus cuidados seu irmão caçula, Jehan. Essa criança órfã e indefesa desperta a afeição e o amor de Claude Frollo, que passa a dedicar-lhe a vida.

Desde então, sentido que havia um fardo a carregar, ele toma sua vida a sério. Pensar em seu pequeno irmão torna-se não

${ }^{47}$ HUGO, 2009. p. 242 
apenas uma recreação, como também o objetivo de seus estudos. Ele decide consagrar-se por inteiro a um futuro em que ele responderia diante de Deus, não tendo esposa nem outra criança que não fosse a alegria e a fortuna de seu irmão. ${ }^{48}$

Como postulado anteriormente, é justamente pelo amor incondicional que dedica a seu irmão que Claude decide adotar Quasimodo. No entanto, ao longo dos anos, todos esses sentimentos de ternura e amor por Jehan transformam-se em desgosto e amargura, ao perceber que o jovem rapaz não seguira o caminho trilhado por ele. Decepcionado com o comportamento e com as atitudes desregradas de Jehan, Frollo dedica-se cada vez mais à ciência, tornando-se rígido enquanto padre e triste enquanto homem.

Como "houvera percorrido desde a sua juventude o ciclo praticamente completo

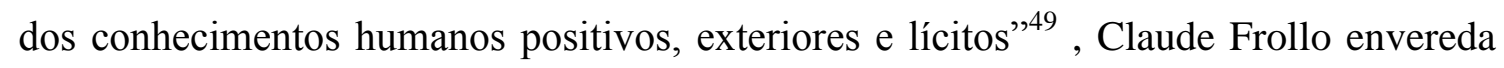
para outros caminhos, a fim de procurar novos alimentos para matar sua fome de conhecimento. "Algumas pessoas sérias afirmavam que após ter esgotado o fasdo saber humano, ele [Frollo] ousara penetrar no nefas." ${ }^{50} \mathrm{O}$ interesse de Frollo pelas ciências ocultas aliado a sua figura imponente e sombria, rendem-lhe a fama de feiticeiro. Os rumores de seu envolvimento com a magia e a bruxaria eram ratificados, para grande parte da população, pela companhia de Quasimodo.

O povo também não se enganava; em quem quer que houvesse um pouco de sagacidade, Quasimodo passava pelo demônio, Claude Frollo pelo feiticeiro. Era evidente que o sineiro devia servir o arquidiácono durante um dado tempo ao fim do qual ele levaria sua alma à guisa de pagamento. ${ }^{51}$

Embora Frollo tenha adotado e criado o jovem sineiro, não há sinais na narrativa hugoana de que o padre cultivasse um sentimento afetuoso por Quasimodo. Ao contrário, a relação entre ambos é definida como entre mestre e cão fiel. Segundo Hugo, Claude tinha em Quasimodo “o escravo mais submisso, o criado mais dócil, o cão mais vigilante. ${ }^{, 52}$ No entanto, apesar do tratamento severo do padre para com ele, Quasimodo devotava um amor profundo por Frollo. Além do fato de o padre lhe ter criado, Frollo era a única conexão que o corcunda tinha com o mundo exterior, a única pessoa com quem ele conseguia se comunicar. Logo, esse misto de medo e gratidão

\footnotetext{
${ }^{48}$ HUGO, 2009,. p. 244

${ }^{49}$ Idem, p. 259

${ }^{50}$ Idem, p. 259

${ }^{51}$ Idem, p. 262 e 263
}

Texto fonte: Le peuple ne s'y méprenait pas non plus ; chez quiconque avait un peu de sagacité, Quasimodo passait pour le démon, Claude Frollo pour le sorcier. Il était évident que le sonneur devait servir l'archidiacre pendant un temps donné au bout duquel il emporterait son âme en guise de paiement. ${ }^{52}$ Idem, p. 255 
corrobora para que Quasimodo obedeça e submeta-se às mais variadas ordens emanadas de Frollo.

Essa relação de mestre e servo é um dos pontos chaves abordados por Roland Petit na narrativa coreográfica. Assim como no romance, Frollo é um homem austero e sinistro que tem por companheiro fiel o jovem Quasimodo. Esse vínculo de subordinação é repassado para dança por meio do posicionamento no palco de ambos personagens. Quando aparecem em cena ao mesmo tempo, Quasimodo sempre está ajoelhado, ocupando o plano baixo do palco. Frollo, por sua vez, posiciona-se sempre em pé ao lado de Quasimodo, executando movimentos que valorizam o plano superior.

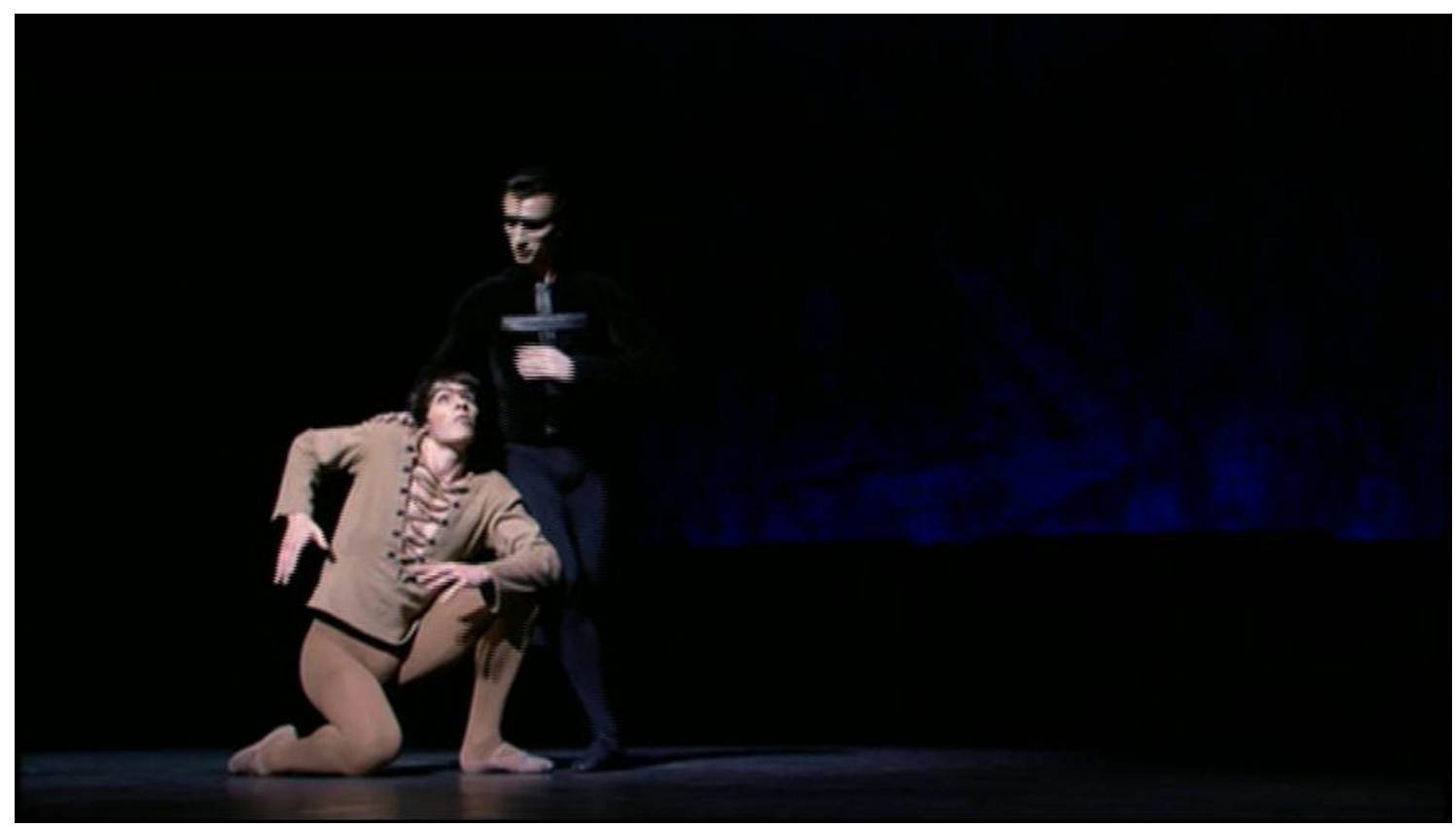

Figura 2 - Claude Frollo e Quasimodo, em Notre-Dame de Paris, 1996

Além da relação com Quasimodo, Roland Petit retém outras características importantes associadas a Claude Frollo no romance hugoano. Em 1482, ano da trama de ambas as narrativas, Claude é descrito como um homem imponente e sombrio, o qual provocava temor a todos. Sua figura austera contribuía para aumentar ainda mais a sua fama de feiticeiro e, consequentemente, o sentimento de pavor que despertava nos demais.

Todavia, a faceta mais amedrontadora da personalidade de Frollo revela-se apenas face ao desejo que a bela Esmeralda lhe aguça. A intensidade desta paixão somada à rejeição de Esmeralda conduzem Frollo a cometer uma série de atos violentos, o que o caracteriza como um monstro moral. Essa deformidade moral é acentuada por 
Roland Petit que, na narrativa coreográfica, recria um Frollo atormentado pela paixão desenfreada que sente pela jovem cigana.

\title{
2.1.3 Phœbus
}

Em Notre-Dame de Paris, Phœbus de Châteaupers é retratado como um belo oficial da cavalaria do rei. Sua beleza física, sua habilidade como arqueiro assim como sua posição social são destacadas no romance, onde o personagem é comparado em diversos momentos a um deus. De fato, a beldade reluzente do jovem capitão está subentendida até na escolha de seu nome, o qual significa "sol"em latim. Entretanto, apesar de sua sedutora aparência física, Phœbus não é um tradicional herói romântico. Sua beleza contrasta com o seu caráter medíocre. Hugo descreve Phœbus como um homem de hábitos vulgares, o qual alimenta um certo gosto pelos prazeres carnais.

Ainda que de nascimento bastante nobre, ele havia contraído sob a armadura mais de um hábito de soldado. A taberna lhe aprazia, e o que se segue.Ele estava à vontade apenas entre os palavrões, as galanterias militares, as belezas fáceis e o sucesso fácil. Ele havia, entretanto, recebido alguma educação de sua família e alguns modos; mas ele havia percorrido o país muito jovem, dado guarnição muito jovem, e todos os dias o verniz do gentil-homem apagava-se à dura fricção de seu cinturão de gendarme. ${ }^{53}$

Seguindo os preceitos impostos por sua classe social, Phœbus firma o compromisso de se casar com a jovem Fleur-de-Lys. Entretanto, sua relação com essa personagem baseia-se meramente em interesses pessoais e sociais.

\begin{abstract}
Aos sorrisos, aos pequenos sinais de inteligência de senhora Aloïse, às piscadelas de olhos que ela lançava em direção a sua filha Fleur-de-Lys, falando baixo ao capitão, era fácil de ver que se tratava de algum noivado consumado, de algum casamento próximo, sem dúvida entre o jovem e Fleur-de-Lys. E à frieza envergonhada do oficial, era fácil ver que, ao menos de seu lado, não se tratava mais de amor. ${ }^{54}$
\end{abstract}

\footnotetext{
${ }^{53}$ HUGO, 2009, p. 194

Texto fonte: Quoique de fort noble naissance, il avait contracté sous le harnois plus d'une habitude de soudard. La taverne lui plaisait, et ce qui s'ensuit. Il n'était à l'aise que parmi les gros mots, les galanteries militaires, les faciles beautés et les faciles succès. Il avait pourtant reçu de sa famille quelque éducation et quelques manières; mais il avait trop jeune couru le pays, trop jeune tenu garnison, et tous les jours le vernis du gentilhomme s'effaçait au dur frottement de son baudrier de gendarme ${ }^{54}$ Idem, p. 195

Texto fonte: Aux sourires, aux petits signes d'intelligence de madame Aloüse, aux clins d'yeux qu'elle détachait vers sa fille Fleur-de-Lys, en parlant bas au capitaine, il était facile de voir qu'il s'agissait de quelque fiançailles consommée, de quelque mariage prochain sans doute entre le jeune homme et Fleur-de-Lys. Et à la froideur embarrassée de l'officier, il était facile de voir que, de son côté du moins, il ne s'agissait plus d'amour.
} 
Apesar de seu comprometimento com Fleur-de-Lys, Phœbus não abandona sua vida de prazeres, continuando a frequentar as tavernas e a seduzir mulheres. É justamente esse gosto pela vida mundana que conduz o personagem a se relaciona com Esmeralda. Na narrativa textual, o encontro entre Esmeralda e Phœbus ocorre quando o belo capitão dos arqueiros salva a jovem cigana capturada por Quasimodo. Ludibriada pela beleza de Phœbus, Esmeralda apaixona-se à primeira vista pelo formoso arqueiro do rei. Todavia, o noivo de Fleur-de-Lys não alimenta mais do que um desejo carnal pela cigana, a qual, em razão de sua classe social e sua origem, não representa mais do que uma simples conquista para ele.

O carácter medíocre de Phœbus e sua inclinação para os prazeres carnais estão entre os traços de sua personalidade resgatados pela narrativa coreográfica. Em um primeiro momento, Phœbus é apresentado ao público como um valente cavaleiro do rei que salva Esmeralda das garras de Quasimodo. Porém, nas cenas subsequentes, Phœbus aparece em meio a prostitutas em um cabaré, para aonde leva Esmeralda. A forma como o personagem interage com as demais bailarinas revela a familiaridade do capitão com aquele ambiente.

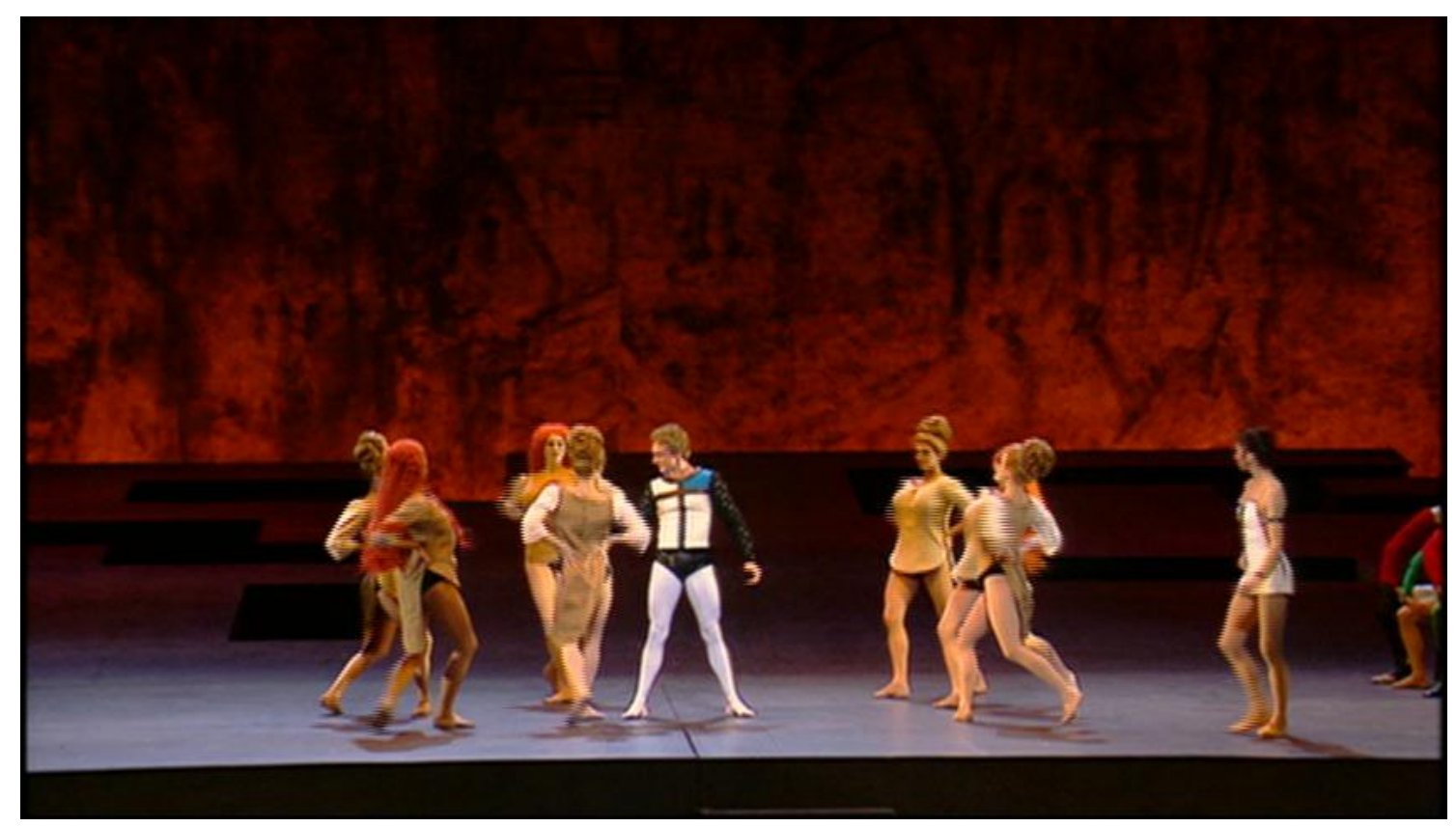

Figura 3 - Phobus e as prostitutas, em Notre-Dame de Paris, 1996

Em virtude da redução do número de personagens no balé e do fato da narrativa coreográfica concentrar-se apenas na figura feminina de Esmeralda, a personagem Fleur-de-Lys não é retratada na dança nem no libreto. Logo, Phœbus não possui 
vínculos afetivos e/ou sociais com nenhuma outra mulher, o que ressalta ainda mais a sua faceta vulgar.

\subsubsection{Esmeralda}

Objeto de desejo dos três personagens masculinos citados anteriormente, Esmeralda é descrita como uma jovem cigana a qual dançava e realiza truques com a sua cabra Djali (esta também ausente do balé de Petit), a fim de ganhar a vida. Sua primeira menção na narrativa de Notre-Dame de Paris ocorre sob a fala do poeta Gringoire que, ao vê-la dançando, fica fascinado com tamanha beleza. O deslumbramento perante a pequena dançarina leva Gringoire até mesmo a questionar a natureza humana do personagem, não sabendo definir se ela seria uma fada, um anjo ou, ainda, um ser humano.

Ela era morena, mas supunha-se que a luz de sua pele devia ter esse belo reflexo dourado das andaluzas e dos romanos. Seu pequeno pé também era andaluz, pois ele estava apertado e à vontade em seu gracioso sapato. Ela dançava, girava, turbilhonava sobre um velho tapete persa, jogado descuidadamente sob seus pés; e cada vez que seu rosto radiante passava na sua frente, seus grandes olhos negros lhe lançavam um relampejo. ${ }^{55}$

A beleza exótica de Esmeralda associada a sua dança ao som do tamborim encanta não apenas a Gringoire e a multidão presente, como também ao sombrio padre Claude Frollo, que assistia a toda a cena absorvido na contemplação da jovem cigana. De acordo com Vignette, a fala de Gringoire a respeito da aparência física e da dança de Esmeralda contém elementos que permitem entrever a dualidade desse personagem.

$\mathrm{O}$ verbo «fascinar» remete à feitiçaria : fascinum é um charme, um malefício, é também a representação ritual do membro viril. Por outro lado, a palavra "visão", a qual é cada vez mais é acrescentado o luminoso qualificador "deslumbrante", revela o vocabulário teológico e evoca o acesso a uma representação divina. Assim, se sua imagem é "radiante", seus "grandes olhos negros" lançam "um relampejo", hipnótico, sedutor. Todo seu personagem é atravessado por essa ambiguidade, tanto ela parece reunir os contrários, tanto são indistintos nela

\footnotetext{
${ }^{55}$ HUGO, 2009, p. 55.

Texto fonte: Elle était brune, mais on devinait que le jour sa peau devait avoir ce beau reflet doré des Andalouses et des Romaines. Son petit pied aussi était andalou, car il était tout ensemble à l'étroit et à l'aise dans sa gracieuse chaussure. Elle dansait, elle tournait, elle tourbillonnait sur un vieux tapis de Perse, jeté négligemment sous ses pieds ; et chaque fois qu'en tournoyant sa rayonnante figure passait devant vous, ses grands yeux noirs vous jetaient un éclair.
} 
a realidade e a aparência: "Ela não era grande, mas o parecia ser (...)Ela era morena, mas supunha-se que a luz de sua pele devia ter esse belo reflexo dourado(...) Seu pequeno pé (...) estava apertado e à vontade em seu gracioso sapato". Se seus braços são "puros", sua dança não é menos impregnada de erotismo: "seus ombros nus, suas pernas finas que sua saia descobria por momentos, seus cabelos negros, seus olhos de flâmula, rodopiam em uma dança de sedução. ${ }^{56}$

Logo, na narrativa textual Esmeralda constitui-se como uma personagem dual apresentando-se ora como uma menina frágil e inocente, ora como uma mulher sensual e sedutora. Tal ambiguidade é recuperada por Roland Petit no balé. Entretanto, a cigana concebida pelo coreógrafo adquire uma faceta mais ousada. A personagem mostra-se uma mulher segura de si, capaz de ações mais ousadas para realizar, por exemplo, sua paixão por Phœbus.

Ademais, Roland Petit omite a gênese e a estória de Esmeralda, que demonstra a ligação entre o destino da dançarina e o de Quasimodo. Não há, na narrativa coreográfica, nenhuma referência ao fato de ambos terem sido trocados um pelo outro enquanto crianças, ou ainda de Esmeralda ter sido sequestrada dos braços de sua mãe Gudule pelos ciganos enquanto criança, o que faz com a personagem cresça como uma menina sozinha e marginalizada. Toda essa história envolvendo mãe e filha é omitida na narrativa coreográfica que se concentra na personalidade de Esmeralda e nos vínculos afetivos que a une aos três protagonistas da obra.

\footnotetext{
${ }^{56}$ VIGNEST, disponível em: http://www.aplettres.org/Esmeralda.htm
} 


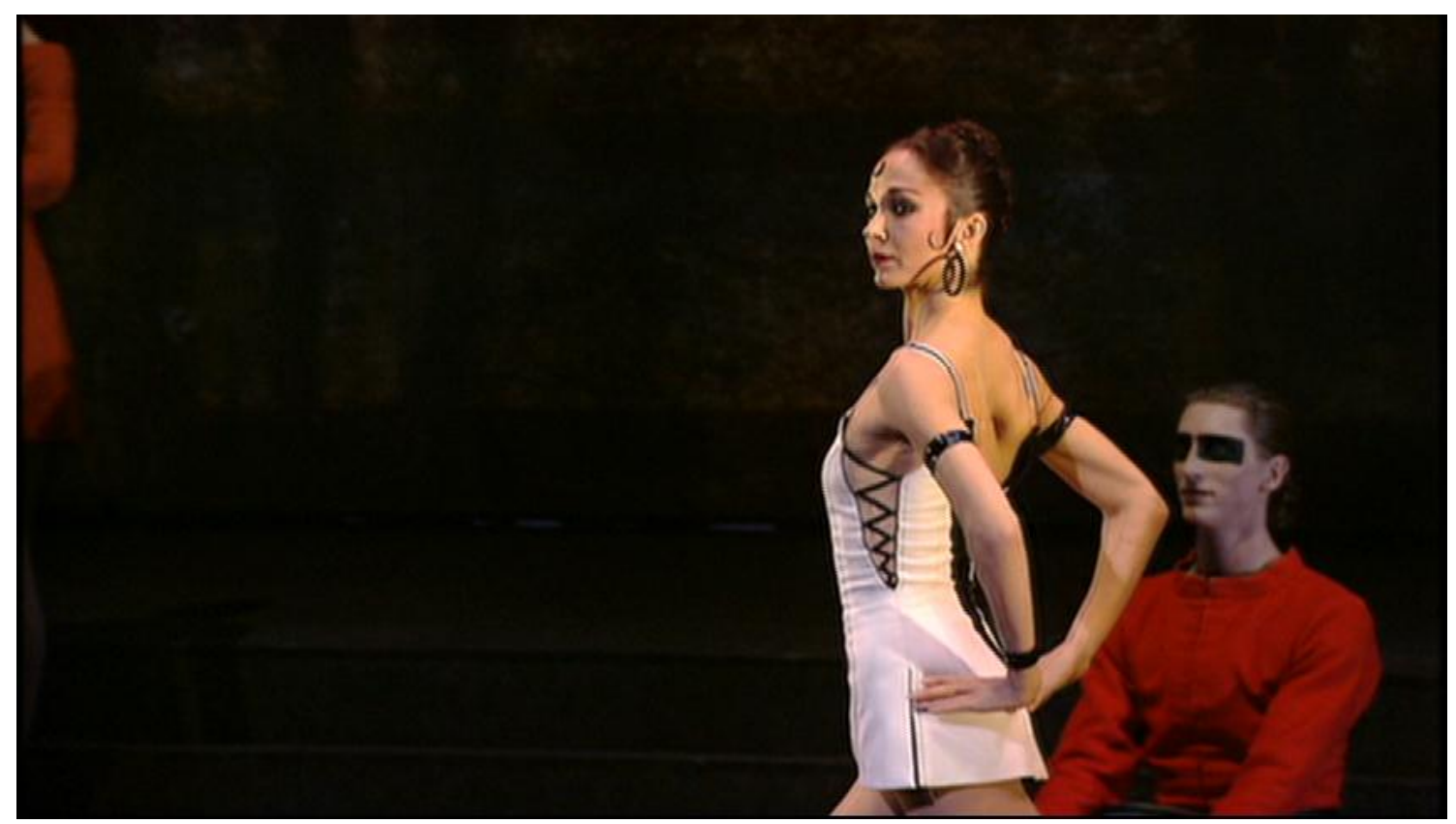

Figura 4 - Esmeralda, em Notre-Dame de Paris, 1996

\subsection{As relações de amor e monstruosidade}

Embora Notre-Dame de Paris seja um romance permeado de digressões e discussões de cunho filosófico, histórico e social, sua trama pode ser analisada a partir das relações amorosas estabelecidas entre Esmeralda - figura feminina central - e importantes personagens masculinos da obra: Quasimodo, Claude Frollo e Phœbus. Cada um desses personagens mantém com Esmeralda uma relação de natureza amorosa, as quais variam em diferentes intensidades entre o amor ao desejo perverso.

As relações afetivas de distintas gradações permitem o nosso entendimento a respeito do amor na obra hugoana. Para Victor Hugo, o amor pode ser compreendido tanto como uma força poderosa, capaz de revelar o que há de mais sublime dentro de nós, como pode ser o motor que desencadeia uma potência negativa, a qual deflagra as deformidades morais de certos indivíduos.

A partir dos vínculos afetivos que unem o destino trágico desses personagens, Hugo desenvolve um segundo tema: a monstruosidade. Assim, na narrativa de NotreDame de Paris há o confronto de monstruosidades distintas na trama amorosa: a monstruosidade física de Quasimodo e a monstruosidade moral de Claude Frollo.

De acordo com Barreto, a monstruosidade apresenta uma ambivalência na obra de Victor Hugo, pois os seres que são denominados como monstros físicos possuem uma alma bondosa e generosa. No caso de Quasimodo, essas características positivas revelam-se a partir do amor sublime que ele sente por Esmeralda. Por outro lado, os 
indivíduos designados como monstros morais apresentam uma alma perturbada, movida por uma potência negativa que os conduz à prática de más ações. Esse fato pode ser percebido no romance por meio da figura de Claude Frollo, em quem a monstruosidade é despertada pela paixão incontrolável que alimenta por Esmeralda.

Assim, com o propósito de entendermos como o amor e a monstruosidade se entrelaçam no romance, analisaremos as relações de amor e paixão estabelecidas entre os personagens assim como em seus efeitos e consequências.

\subsubsection{Esmeralda e Quasimodo}

A relação que une o sineiro Quasimodo e a cigana Esmeralda é marcada tanto no romance quanto na dança pela aliança dos contrários. $\mathrm{O}$ aspecto físico de ambos personagens fazem deles seres antitéticos: Esmeralda é concebida como a personificação da beleza, enquanto que Quasimodo é considerado um ser monstruoso devido à sua fealdade e a suas deformidades físicas.

Os vínculos afetivos que aproximam esse casal inusitado da narrativa hugoana foram inspirados, de acordo com Barreto, em conto que há séculos habita o imaginário popular: A Bela e a Fera. A estória da bela jovem e da fera que se apaixonam perdidamente tornou-se célebre em 1756, pelas mãos da escritora Jeanne-Marie Leprince de Beaumont. Entretanto, a trama desse conto teria sido inspirada em outra obra, l'Histoire de la princesse Zeineb et du roi Léopard, de Jean-Paul Bignon, escrita em 1712.

Todavia, conforme Barreto explica, a estória contada por Victor Hugo nutre-se de elementos trágicos, os quais não são apresentados no conto original. Em Notre-Dame de Paris, a história entre a bela e a fera revela-se um amor impossível. Quasimodo devota um amor puro por Esmeralda, enquanto que a jovem cigana demonstra apenas amizade e gratidão pelo sineiro.

Apesar da aparente oposição entre ambos, suas trajetórias se entrelaçam em diversos momentos da trama. Como explicitado anteriormente, Quasimodo e Esmeralda foram trocados um pelo outro quando ainda eram crianças e ambos crescem sem suas famílias. Já na fase adulta, seus destinos se cruzam e Esmeralda conquista o amor e a lealdade de Quasimodo. A origem comum e a forma como as vidas de ambos se interceptam em distintos instantes da trama revelam, de acordo com Barreto, uma laço de equivalência entre Quasimodo e Esmeralda, não obstante suas aparências. 
"Quasimodo é, então, o substituto de Esmeralda; a bela e a fera funcionam como uma espécie de quase-gêmeos"

O amor impossível que Quasimodo nutre por Esmeralda é de suma importância para a compreensão de sua personalidade dual, uma vez que é justamente por meio desse amor sublime que a bondade e a pureza de sua alma são colocadas em evidência. Sabemos que, apesar de sua feiura e de suas deformidades físicas, Quasimodo possui uma alma generosa, dotada de belos sentimentos. Entretanto, esses são encobertos tanto por seu corpo defeituoso quanto pelo sentimento de raiva e ruindade que aprendera com a sociedade que o humilhava e o rejeitava.

Antes de conhecer Esmeralda, Quasimodo nunca provara do amor para com outro ser humano. Suas relações se limitavam ao convívio com Claude Frollo, seu pai adotivo, por quem cultivava um misto de gratidão e obediência. Excluído pela sociedade que o maltratava em virtude de sua aparência grotesca, Quasimodo refugia-se em NotreDame e faz daquele espaço o seu universo. Sua grande paixão, até então, eram os quinze sinos da catedral. Embora eles tenham-no tornado surdo, Quasimodo os considerava como sua família, ele lhes falava, acariciava-os e os compreendia. De fato, eles eram a única coisa que ele ainda ouvia. Segundo Barreto, a reclusão de Quasimodo no ambiente da catedral torna-o um monstro solitário, cuja satisfação sexual realiza-se por meio da relação empreendida com um dos sinos - Marie, sua bem-amada.

Ele [Quasimodo] obterá a amizade e a gratidão de Esmeralda,
mas o amor de Quasimodo não se realizará efetivamente. Ele
continua um monstro virgem e suas relações sexuais parece se
realizar sob uma forma fantasma, nas relações que ele mantém
com o grande sino, 'sua bem-amada', a qual ele chama de
Marie, quando eles se unem na mesma hibridez monstruosa. ${ }^{58}$

Movido por seu amor sublime por Esmeralda, Quasimodo realiza uma série de atos na tentativa de salvar a jovem cigana da morte. Ao ser condenada pelo suposto assassinato de Phœbus, Esmeralda é regatada pelo corcunda que a leva para NotreDame, local de asilo. Embora reconheça a bondade do sineiro e seja grata por suas ações, Esmeralda não consegue corresponder aos sentimentos de Quasimodo, cultivando por ele uma simples amizade. Na realidade, além de ser apaixonada por Phœbus, Esmeralda empreende um grande esforço para esconder seu horror diante da figura disforme de Quasimodo, a qual lhe provoca medo. No entanto, a convivência

\footnotetext{
${ }^{57}$ BARRETO, 2006. p. 97

${ }^{58}$ BARRETO, 2006. p. 93
} 
com esse personagem e os cuidados que ele lhe dedica despertam a compaixão da cigana, que se imbui de um sentimento de ternura e gratidão.

Por sua vez, Quasimodo tem ciência da impossibilidade de realização do amor que sente por Esmeralda. Ele tem conhecimento de seu aspecto grotesco e do horror que esse provoca nos demais, sobretudo na jovem cigana. De fato, a beleza resplandecente de Esmeralda perante a sua figura, faz com que Quasimodo veja sua feiura como nunca dantes.

Jamais vi minha feiura como agora. Quando eu me comparo com você, tenho muita piedade de mim, pobre monstro infeliz que sou! Devo lhe parecer uma besta, diga. -Você, um raio do sol, uma gota de orvalho, um canto de pássaro! - Eu, eu sou algo assustador, nem homem, nem animal, um sei lá o que mais duro, mais pisoteado nos pés e mais disforme que um pedregulho $!^{59}$

Embora seu amor não seja correspondido, Quasimodo realiza todos os esforços possíveis para salvar a vida de Esmeralda. Em virtude desse amor puro e incondicional, ele não hesita, até mesmo, em atentar contra a vida de seu pai adotivo Claude Frollo ao final da trama. Impossibilitado por sua surdez de perceber o que se passava frente à Notre-Dame, Quasimodo crê que a multidão presente tentava invadir a catedral para capturar Esmeralda, acusada de assassinato e bruxaria. Em um ato de desespero, ele tenta impedir a tomada da catedral pelo povo que, efetivamente, buscava resgatar a jovem cigana. Ao se distrair nessa verdadeira batalha contra a multidão, Quasimodo possibilita que Frollo capture Esmeralda, entregando-a a seus executores.

Desesperado ao ver a morte da bela cigana e o riso demoníaco de contentamento do arquidiácono, Quasimodo empurra Claude Frollo das torres de Notre-Dame e desaparece em seguida. Cerca de dois anos depois dos acontecimentos, o esqueleto de Quasimodo é encontrado abraçado ao da jovem Esmeralda no cemitério de MontFaucon.

Assim, podemos perceber que, na narrativa hugoana, a relação entre Esmeralda e Quasimodo baseia-se no encontro entre duas alteridades, dois personagens antitéticos que de alguma forma se complementam. $\mathrm{O}$ amor incondicional que Quasimodo devota por Esmeralda é puro, não exige nada em troca. Tal amor espiritual, revela a enorme

\footnotetext{
${ }^{59}$ HUGO, 2009 p. 311

Texto fonte: Jamais je n'ai vu ma laideur comme à présent. Quand je me compare à vous, j'ai bien pitié de moi, pauvre malheureux monstre que je suis! Je dois vous faire l'effet d'une bête, dites. - Vous, vous êtes un rayon de soleil, une goutte de rosée, un chant d'oiseau! - Moi, je suis quelque chose d'affreux, ni homme, ni animal, un je ne sais quoi plus dur, plus foulé aux pieds et plus difforme qu'un caillou!
} 
bondade presente na alma do sineiro, que até aquele momento escondia-se debaixo de seu corpo disforme. Embora Esmeralda não retribua o amor de Quasimodo da mesma forma, ela não deixa de demonstrar seu afeto e reconhecimento por ele. A compaixão e a gratidão que nutre pelo corcunda são, de fato, mais fortes que o sentimento de medo perante as deformidades físicas de Quasimodo.

\subsubsection{Claude Frollo e Esmeralda}

Destinado ao celibato desde a tenra infância, Claude Frollo não conhecera outro tipo de amor, salvo a paixão que nutria pelo conhecimento e o afeto que dedicara a seu irmão Jehan durante a infância deste. Devido a seu ofício, Frollo buscou afastar-se de qualquer contato com as mulheres, pois sendo essas objeto de desejo e tentação, a distância seria o mais apropriado. De fato, a repulsa pelo sexo oposto é levada a tal ponto que Frollo, por vezes, demonstra ódio pelas mulheres, em especial às egípcias.

Entretanto, ao ver Esmeralda dançando diante da catedral, o jovem padre tem suas convicções abaladas e sua alma atormentada por uma súbito desejo, o qual foge totalmente de seu controle e de sua razão. A intensidade e a violência da paixão que acomete Frollo ao avistar Esmeralda provocam um suplício em seu espírito. Dividido entre as obrigações de seu ofício clerical e o desejo que sente pela dançarina, Frollo incorre em uma série de atos violentos contra Esmeralda, os quais culminam na morte de ambos os personagens no final da trama. De fato, o sofrimento pela rejeição de Esmeralda é maior do que o martírio pela impossibilidade da realização de sua paixão devido aos votos sacerdotais. Conforme afirma Danièle Laster, "como ele [Frollo] não tem nenhuma experiência amorosa, ele sempre acreditou que amar era diabólico, ele não compreende que aquela criatura [Esmeralda] enviada sem dúvidas pelo demônio possa recusá-lo." ${ }^{60}$ Esse sentimento de repúdio da dançarina desperta em Frollo uma potência negativa, geradora de sua deformidade moral, ou seja, de sua monstruosidade. Ainda, de acordo com Laster, a rejeição de Esmeralda revela no padre "a necessidade de se destruir e de destruir o objeto amado",61

Na tentativa de possuir Esmeralda a todo custo, Frollo ordena que Quasimodo rapte a jovem cigana. Entretanto seu plano fracassa ao Phœbus aparecer e resgatá-la a dançarina. Nesse momento, a fatalidade cruza os caminhos de Esmeralda e Phœbus, despertando o amor da cigana pelo arqueiro.

\footnotetext{
${ }^{60}$ LASTER. 2001. p. 3

${ }^{61}$ LASTER. 2001. p. 3
} 
Seduzida por Phœbus, Esmeralda vai ao encontro de seu amado em uma taverna. Entretanto, o que a jovem não sabia, é que Frollo havia barganhado previamente com o capitão um pequeno espaço para se esconder no local de encontro, a fim de ter certeza que a mulher que sairia com Phœbus era realmente Esmeralda. Frollo instala-se em um canto da alcova e observa escondido, por meio de uma fresta, a cena de amor entre Phœbus e Esmeralda. De acordo com Barreto, nessa cena," mais que o desejo de confirmação, observa-se a existência de um lado voyeur do arquidiácono."62 $\mathrm{O}$ ato de observar a tentativa de consumação do ato carnal entre Esmeralda e Phœbus suscita um certo prazer em Frollo. Conforme Laster, "essa impressão ressentida pelo olhar, mostrase como o único sentido que Frollo possui a sua disposição para possuir Esmeralda."

Movido pelo ciúme e por sua obsessão por Esmeralda, Frollo sai de seu esconderijo e golpeia Phœbus com um punhal, o que rende a Esmeralda a acusação de assassinato.

De repente, por cima da cabeça de Phœbus viu uma outra cabeça; um rosto lívido, verde, convulso, com um olhar de condenado; perto desse rosto havia uma mão que segurava um punhal. Era o rosto e a mão do padre; despedaçara a porta e estava ali. Phœbus não o podia ver. A cigana ficou imóvel, gelada, muda com aquela espantosa aparição, como uma pomba que levantasse a cabeça no momento em que um xofrango de olhos redondos lhe examina o ninho. ${ }^{64}$

Após ser torturada e confessar o crime cuja autoria pertencia a Frollo, Esmeralda recebe a visita do padre, o qual permitira que a jovem sofresse sem intervir e confessar sua culpa. Nesse momento, aos prantos, Claude declara sua paixão pela jovem, sentimento o qual ele mesmo classifica como o amor de um condenado.

Não encontro palavras. Tinha contudo pensado bem no que te diria. Agora tremo e arrepio-me, desfaleço no momento decisivo, sinto que alguma coisa de supremo nos envolve, e eu balbucio. Oh! Eu vou cair sobre estas pedras se não tens piedade de mim; piedade de ti. Não nos condenes a ambos. Se soubesses quanto eu te amo! Que coração palpita aqui no meu peito! Oh! Que deserção de toda a virtude! Que abandono desesperado de

\footnotetext{
${ }^{62}$ BARRETO. 2006, p. 299

${ }^{63}$ LASTER. 2001, p. 3

${ }^{64}$ HUGO, 2009, p. 250

Texto fonte: Tout à coup, au-dessus de la tête de Phoebus, elle vit une autre tête, une figure livide, verte, convulsive, avec un regard de damné. Près de cette figure il y avait une main qui tenait un poignard. C'était la figure et la main du prêtre. Il avait brisé la porte et il était là. Phoebus ne pouvait le voir. La jeune fille resta immobile, glacée, muette sous l'épouvantable apparition, comme une colombe qui lèverait la tête au moment où l'orfraie regarde dans son nid avec ses yeux ronds.
} 
mim mesmo! Doutor, ultrajo a ciência; nobre, quebro o meu brasão; padre, faço do missal um travesseiro de luxúria, ofendo o meu Deus! Tudo isto por tua causa, encantadora! Para ser mais digno do teu inferno! E tu repeles o condenado! Oh! Que te diga tudo! Mais ainda, alguma coisa mais horrível, oh! Mais horrível... ${ }^{65}$

Completamente desesperado e sem controle de sua razão, Frollo confessa a Esmeralda tê-la denunciado às autoridades por assassinato e bruxaria na esperança de que um processo fizesse com que a cigana fosse dele. Ele suplica piedade a Esmeralda, afirmando que todo aquele processo e tortura pela qual ela passara, provocou mais sofrimento a ele do que a ela mesma. De acordo com Laster, essa passagem do texto ratifica novamente a dualidade que permeia os personagens e as suas relações em NotreDame de Paris. Obsidiado pelo desejo perverso que sente por Esmeralda, “[...] Frollo é constantemente dividido entre o desejo de acariciar Esmeralda e de torturá-la, de sofrer e de fazê-la sofrer"

Em uma última tentativa de convencer a jovem a aceitar seus sentimentos, Frollo propõe que os dois fujam ou, caso contrário, ele a deixaria ser executada. Horrorizada pela atrocidade das ações do padre, Esmeralda afirma amar apenas Phœbus e diz preferir a morte a estar com Claude. Já Frollo, impulsionado pela raiva da rejeição, prefere ver Esmeralda morta a nos braços de Phœbus.

Ao ser mandada para a forca, Esmeralda é resgatada por Quasimodo e conduzida à catedral. Apesar da aparente segurança, Notre-Dame também era o lar do arquidiácono que se vê novamente tentado por seus desejos e pulsões incontroláveis. Aproveitando da ausência de Quasimodo, este vem atormentar Esmeralda, a qual rejeita seus abraços e suas carícias. Movido pela sua obsessão e por seu delírio passional, Frollo ataca Esmeralda com violência, todavia Quasimodo aparece para salvá-la de seu carrasco.

A proximidade entre Quasimodo e Esmeralda suscita ainda mais o sentimento de indignação e ciúmes em Frollo. Conforme explicita Barreto,"Phœbus era o belo capitão

\footnotetext{
${ }^{65}$ Idem, p. 462

Texto fonte: Je ne trouve pas de paroles. J'avais pourtant bien songé à ce que je vous dirais. Maintenant je tremble et je frissonne, je défaille à l'instant décisif, je sens quelque chose de suprême qui nous enveloppe, et je balbutie. Oh! je vais tomber sur le pavé si vous ne prenez pas pitié de moi, pitié de vous. Ne nous condamnez pas tous deux. Si vous saviez combien je vous aime! quel coeur c'est que mon coeur! Oh! quelle désertion de toute vertu! quel abandon désespéré de moi-même! Docteur, je bafoue la science ; gentilhomme, je déchire mon nom ; prêtre, je fais du missel un oreiller de luxure, je crache au visage de mon Dieu! tout cela pour toi, enchanteresse! pour être plus digne de ton enfer! et tu ne veux pas du damné! Oh! que je te dise tout! plus encore, quelque chose de plus horrible, oh! plus horrible ${ }^{66}$ LASTER. 2001. p. 4
} 
das armas, porém a ideia de ter o grotesco Quasimodo mais próximo e intimo de Esmeralda do que ele, transtornava- o"67

Aproveitando-se da distração de Quasimodo que se esforçava para impedir a invasão de Notre-Dame, Claude rapta Esmeralda com a ajuda de Gringoire e a conduz até a forca, em uma segunda tentativa de convencer a cigana de sua paixão. No entanto, ao perceber que o homem encapuzado que a sequestrara era o padre, Esmeralda afirma veementemente que a forca lhe causava menos horror que a figura sombria de Frollo. Atormentado pelas palavras de desprezo de Esmeralda, Frollo profere uma série de súplicas e ameaças contra a egípcia. Todavia, a jovem cigana permanece irredutível em sua resolução. A loucura e o desespero que aquele sentimento de rejeição the provoca impeliram Frollo a levar Esmeralda para Gudule, a qual a entrega à justiça logo após descobrir que se tratava de sua filha.

Sem demonstrar maiores arrependimentos, Claude Frollo assiste ao enforcamento de Esmeralda do alto das torres de Notre-Dame, esboçando alguma reação apenas no momento em que a cigana desfalece. Nesse instante, o padre solta um riso demoníaco, o qual suscita a raiva de Quasimodo que, por sua vez, empurra-o do alto da catedral. Antes de atingir o solo Frollo dá seu último grito, o qual resume sua história com Esmeralda: "Danação!"68

Portanto, em Notre-Dame de Paris, temos um personagem atormentado pela dupla impossibilidade de realização de sua paixão libidinosa: a proibição de seu ofício e a rejeição de Esmeralda, que prefere a morte à figura de Claude Frollo. A inviabilidade de consumação de seu desejo conduz o padre a mentir, sequestrar chantagear e até mesmo a uma tentativa de assassinato contra Phœbus. Todos esses crimes deflagram a deformidade moral do personagem, ou seja, a sua monstruosidade.

Ao contrário de Quasimodo que dedica um amor puro e incondicional à Esmeralda, Frollo nutre um desejo ardente pela cigana. Essa pulsão incontrolável, uma vez não consumada, transforma-se em uma "potência negativa, geradora de deformidades." ${ }^{69}$ Assim, a paixão que o solitário Frollo alimenta por Esmeralda é, na verdade, a causa de sua danação.

\footnotetext{
${ }^{67}$ BARRETO, 2006, p. 303

${ }^{68}$ HUGO, 2009, p. 401

${ }^{69}$ BARRETO, 2006, p. 304
} 


\subsubsection{Phœbus e Esmeralda}

$\mathrm{Na}$ narrativa textual, o primeiro encontro entre Esmeralda e Phœbus ocorre quando o belo capitão dos arqueiros salva a jovem cigana capturada por Quasimodo. Iludida pela premissa de que aquilo que é belo é bom, Esmeralda apaixona-se à primeira vista pelo formoso arqueiro do rei. Todavia, Esmeralda não imaginava que o formoso capitão era, efetivamente, um homem de hábitos vulgares; frequentador assíduo de cabarés e prostitutas.

Embora cultivasse um gosto pela vida promíscua, Phœbus ocupava uma posição social de destaque, a qual the exigia o cumprimento de algumas obrigações como, por exemplo, o matrimônio. A fim de manter as aparências, Phœbus pede a mão de Fleurde-Lys em casamento, conquanto não alimentasse nenhum sentimento pela jovem dama da sociedade.

Ao conhecer Esmeralda, Phœbus fica encantado com a sua beleza e vê na figura da jovem cigana apenas mais uma oportunidade de realizar sua concupiscência. De fato, Phœbus não alimenta mais do que um desejo carnal pela cigana. Não há de sua parte nenhuma intenção de um compromisso com Esmeralda, pois esta é apenas uma cigana marginalizada pela sociedade, não correspondendo ao seu nível social. Todavia, a fim de consumar seu desejo, ele mente para Esmeralda sobre sua situação e seus sentimentos, prometendo ficar com ela. Perdidamente apaixonada e ludibriada com o juramento de amor de Phœbus, Esmeralda dirige-se até uma mal afamada taverna, onde se entrega a seu amado.

Para Esmeralda, ter o amor de um belo capitão como Phœbus era a realização de um sonho. Pura e inocente, a jovem fantasiava em ser resgatada por um nobre que lhe devotasse um grande amor e a retirasse daquela vida marginalizada que ela levava. Assim seu amor por Phœbus não era apenas a concretização de um afeto, era também a oportunidade da pobre órfã casar-se com alguém que lhe daria um nome.

Phœbus, prosseguiu a cigana tirando suavemente de sua cintura as mãos tenazes do capitão, você é bom, generoso, belo. Você me salvou, eu, que sou apenas uma pobre criança perdida na Boêmia. Há muito tempo que eu sonho com um oficial que me salve a vida. Era com você que eu sonhava antes de te conhecer, meu Phœbus. Meu sonho tinha um belo libré como você, uma grande 
aparência, uma espada. Você se chama Phœbus, é um belo nome. Eu amo seu nome, amo sua espada. ${ }^{70}$

Assim, sob as juras de amor de Phœbus, Esmeralda entrega-se ao capitão. Seu amor por ele é tão profundo que, em determinado momento, amedrontada por uma possível rejeição de Phœbus, o qual diz não acreditar no casamento; Esmeralda diz não se importar em ser apenas sua amante.

A minha alma, a minha vida, o meu corpo, a minha pessoa, tudo isso é uma coisa que vos pertence, meu capitão. Pois bem! Não, não nos casaremos. Isso aborrece-te, e depois, quem sou eu? Uma miserável filha das tristes ervas; enquanto tu, meu Phœbus, tu és fidalgo. Era bonito, em verdade, uma bailarina desposar um oficial! Estava louca. Não, Phœbus, não; serei a tua amante, a tua distração, o teu prazer, quando tu quiseres, uma mulher que é tua. ${ }^{71}$

Aproveitando-se da situação, “o capitão inebriado colou os lábios ardentes naquelas famosas espáduas africanas. ${ }^{, 72}$ Entretanto, Claude Frollo, que espreitara toda a cena até então, sai de seu esconderijo e sem que Esmeralda perceba desferi um golpe de punhal contra Phœbus.

Como explicitado anteriormente, Esmeralda é acusada pelo o assassinato de Phœbus. Acreditando ter realmente perdido seu grande amor para sempre, Esmeralda prefere à morte a ser possuída por Claude Frollo.

Por sua vez, Phœbus, que ficara apenas ferido, também não escapa de um final trágico, segundo sua própria perspectiva. Após não intervir no processo de acusação de Esmeralda, ele casa-se com Fleur-de-Lys.

\footnotetext{
${ }^{70}$ HUGO, 2009. p. 246

Texto fonte: Phoebus, poursuivit la bohémienne en détachant doucement de sa ceinture les mains tenaces du capitaine, vous êtes bon, vous êtes généreux, vous êtes beau. Vous m'avez sauvée, moi qui ne suis qu'une pauvre enfant perdue en Bohême. Il y a longtemps que je rêve d'un officier qui me sauve la vie. C'était de vous que je rêvais avant de vous connaître, mon Phoebus. Mon rêve avait une belle livrée comme vous, une grande mine, une épée. Vous vous appelez. Phoebus, c'est un beau nom. J'aime votre nom, j'aime votre épée

${ }^{71}$ HUGO, 2009. p. 250

Texto fonte: Mon âme, ma vie, mon corps, ma personne, tout cela est une chose qui est à vous, mon capitaine. Eh bien, non! ne nous marions pas, cela t'ennuie. Et puis, qu'est-ce que je suis, moi? une misérable fille du ruisseau, tandis que toi, mon Phoebus, tu es gentilhomme. Belle chose vraiment! une danseuse épouser un officier! j'étais folle. Non, Phoebus, non, je serai ta maîtresse, ton amusement, ton plaisir, quand tu voudras, une fille qui sera à toi

${ }^{72}$ Idem, p. 250
} 


\subsubsection{Pierre Gringoire e Esmeralda}

Apesar de não ser retratado no balé de Roland de Petit, o poeta Pierre Gringoire exerce um papel fundamental na obra hugoana, pois, de acordo com Seebacher, ele seria "o espelho do escritor, o alter ego de Victor Hugo" ${ }^{, 73}$ Logo, a retirada desse personagem da narrativa coreográfica implicaria em um apagamento da marca do escritor tão presente no texto literário.

Ao seguir Esmeralda pelas ruas de Paris, Gringoire adentra o Pátio dos Milagres onde é condenado à forca por Clopin Trouillefou. Compadecendo-se da situação do poeta, Esmeralda aceita se casar com ele o livrando da morte. Embora marido e mulher face às leis que regiam o Pátio dos Milagres, Gringoire e Esmeralda não consumam sua relação. Diante da recusa de Esmeralda em deitar-se com ele, Pierre Gringoire sente-se cada vez mais atraído por Djali, a cabra "doce, inteligente e espirituosa",74 da jovem cigana, que o "cobre de carícias e pelos brancos."75

Entretanto, a fatalidade que rege a obra hugoana faz com que Gringoire e Esmeralda sejam separados em definitivo pelo mesmo motivo que o seu casamento fora realizado: a condenação ao enforcamento. Visando recuperar Djali que estava no asilo de Notre-Dame ao lado de Esmeralda, o poeta decide ajudar Claude Frollo a tirar Esmeralda da catedral. Logo, no lugar de retribuir o favor de Esmeralda, Gringoire atua como um dos responsáveis pelo destino fatal da jovem cigana, preferindo salvar a cabra à dançarina. Assim, podemos inferir que, embora o poeta contribua para o fim trágico de Esmeralda, ambos desenvolvem, ao menos em um primeiro momento, um afeto fraternal, principalmente no que concerne os sentimentos da dançarina pelo poeta.

Por conseguinte, tendo em vista todas as relações de amor e monstruosidade retratadas no romance e descritas neste capítulo, podemos propor um mapeamento desses afetos a partir do seguinte esquema:

\footnotetext{
${ }^{73}$ SEBAACHER, 1972, p.101

${ }^{74}$ HUGO, 2009, p.206

${ }^{75}$ HUGO, 2009, p.458
} 


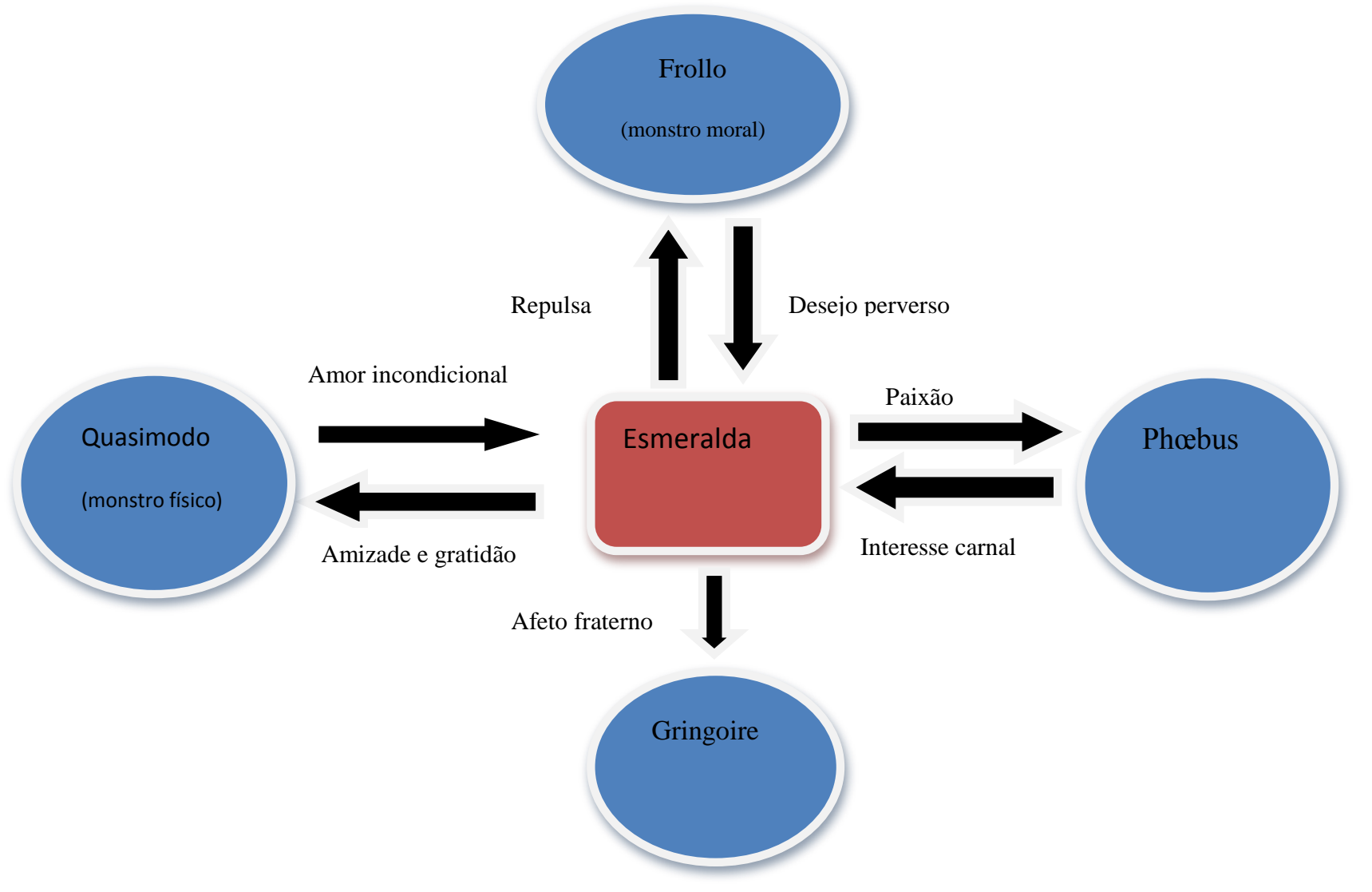




\section{CAPÍTULO III}

\section{Pensar a dança: as diversas escrituras possíveis}

A tarefa de analisar um espetáculo de dança, independente de seu estilo, implica na definição e escolha de determinados conceitos. Por este motivo, antes mesmo de pensarmos no processo de composição da obra, faz-se necessário delimitarmos o que entendemos como dança neste trabalho e qual a sua função.

$\mathrm{Na}$ introdução de seu ensaio Dançar a vida, o filósofo Roger Garaudy afirma que a dança é um modo de existir. Para o autor, a dança está intimamente relacionada aos mais diversos aspectos da vida humana, como ao trabalho, à religião, ao amor e, até mesmo, à morte. Forma de expressão, através de movimentos do corpo ressemantizados organizados em sequências significativas, de experiências que transcendem o poder da palavra e da mímica, a dança deve ser considerada, portanto, não apenas como uma forma de arte, mas como um modo de viver.

É fato que a dança esteve presente nas mais diversas organizações sociais desde os primórdios da humanidade. $\mathrm{O}$ homem dançou em praticamente todos os momentos de sua existência, fosse apenas para aquecer o corpo ao redor da fogueira durante a préhistória, ou ainda, para celebrar acontecimentos de sua existência como a guerra, o casamento, o funeral, a colheita, a mudança de estação, entre outros.

Dançar é uma manifestação instintiva ao homem, uma forma de comunicação e expressão de sua relação com a natureza e com a sociedade ao seu redor. Tal fato pode ser percebido pelo significado da própria palavra dança em diversas línguas europeias. Segundo Garaudy,

[...] em todas as línguas europeias - danza, dance, tanz -, deriva da raiz tan que, em sânscrito, significa "tensão". Dançar é vivenciar e exprimir, com o máximo de intensidade, a relação do homem com a natureza, com a sociedade, com o futuro e com os seus deuses. ${ }^{76}$

Por meio dessa definição elaborada por Garaudy, podemos constatar que a dança sempre esteve ligada à expressão do homem, à sua forma de se comunicar com o outro, com o mundo e consigo mesmo. Logo, é importante salientar que, neste trabalho,

\footnotetext{
${ }^{76}$ GARAUDY.1973, p. 14.
} 
partiremos do princípio de que a dança é um fenômeno complexo de linguagem, em que diversos elementos entrelaçados compõem um todo de sentido.

Uma vez considerada um fenômeno de linguagem, a dança forma uma complexa rede de signos. Portanto, cabe-nos, ainda, entender, como uma sequência de movimentos ritmados assume significado para o homem.

De acordo com Trotta, "a motricidade humana é entendida como um fenômeno social, ou seja, a gesticulação natural, à medida que é aprendida e transmitida, como outros sistemas semióticos, transforma-se em gesticulação cultural". 77 Enquanto gesticulação cultural, a dança cria sentido para o homem, desde que seja entendida como um contrato de comunicação, o qual pressupõe um remetente-codificador e um destinatário-intérprete. Em um espetáculo de dança, esses papéis são interpretados, respectivamente, pelo coreógrafo e seu público. Ao estabelecer uma relação contratual com o espectador, o coreógrafo utiliza-se da persuasão para fazer, por exemplo, com que o público reconheça na figura delicada de um bailarino, uma figura bestial como o personagem monstro Quasimodo.

Ainda de acordo com Trotta, "o desejo de fazer-parecido, de fazer-crer, manifestado por este ou aquele coreógrafo, por esta ou aquela escola, é o que define o contrato fiduciário que resulta na iconização da dança". ${ }^{78}$ Portanto, a dança só pode ser concebida como linguagem se ela for pensada como comunicação gestual.

Além disso, deve-se considerar que a dança, enquanto plano de expressão, constitui um texto sincrético. Segundo Teixeira,

Textos sincréticos são aqueles em que o plano da expressão se caracteriza por uma pluralidade de substâncias mobilizadas por uma única enunciação cuja competência de textualizar supõe o domínio de várias linguagens para a formalização de uma outra que a organize num todo de significação. ${ }^{79}$

Em outras palavras, para o estudo de uma obra coreográfica devemos levar em conta não apenas os gestos produzidos pelos bailarinos, mas a música, o figurino, o cenário e a iluminação. Juntos, esses elementos compõe um todo de sentido e apenas analisando-os como tal é que podemos verificar as possibilidades de relação destes com o conteúdo da obra literária.

\footnotetext{
${ }^{77}$ TROTTA. 2011, p. 1.

${ }^{78}$ Idem, p. 2

${ }^{79}$ TEIXEIRA apud TROTTA, 2011, p.6
} 
Assim, neste capítulo, buscaremos entender como a música de Maurice Jarre, o figurino de Yves Saint Laurent, o cenário de René Allio e a iluminação de Jean-Michel Désiré contribuem para o trabalho coreográfico de Roland Petit, agregando assim sentido ao balé e, consequentemente, ao próprio texto hugoano. Como expresso na introdução, por se tratar de um elemento complexo, a gestualidade - a coreografia de Roland Petit - será analisada isoladamente em um capítulo posterior.

\subsection{Da música}

De modo geral, a dança e a música parecem-nos tão intimamente ligadas, que se torna difícil dissocia-las. Isso acontece, pois, além de aguçarem a sensibilidade do coreógrafo e do espectador, ambas têm a função de comunicar. Entretanto, estudiosos dessas áreas têm se questionado sobre o estatuto da música no interior de um espetáculo de dança. Deveria a coreografia acompanhar fielmente a música? A música serviria, então, apenas como suporte para a dança ou funcionaria como um impulso criador da gestualidade ? O coreógrafo deve criar seu argumento e sua coreografia baseado em uma música pré-existente ou deve encomendar uma composição original a determinado compositor?

Em meio a tantos questionamentos, uma coisa é fato: a música e a dança não podem ser estudadas isoladamente na análise de um balé. Elas só podem ser compreendidas a partir das relações que estabelecem entre si. E para compreendermos a concepção e a importância da música de Maurice Jarre no balé de Petit, faz-se necessário realizamos uma breve recapitulação da analogia entre música e dança ao longo do tempo.

$\mathrm{Na}$ dança clássica, a gestualidade deve estar em harmonia com a música. Essa funciona como um guia para os movimentos dos bailarinos, que são realizados em sincronia com a métrica musical. De acordo com Trotta, essa relação entre as duas formas de arte é tão forte "de maneira que, ao se fechar os olhos, pode-se imaginar a bailarina e ao se fechar os ouvidos, pode-se escutar a música pelos gestos da bailarina" ${ }^{\prime 80}$. O primor pela sincronia entre a dança clássica e a música exige, tanto dos dançarinos quanto dos músicos, um grande domínio técnico, uma vez que os princípios tonais e harmônicos devem ser respeitados. Nesta modalidade de dança, as partituras são compostas, geralmente, em função dos passos criados pelo coreógrafo. Este escreve seu argumento, cria sua história, desenvolve sua coreografia e, ao final, encomenda uma 
música que se adapte à sua obra; fazendo suas imposições e exigências. Além disso, na dança clássica, observa-se uma estrutura pré-definida tanto para a música quanto para o espetáculo, que seguem o seguinte roteiro: entrada, adágio ${ }^{81}$, variações separadas para a primeira bailarina e o principal bailarino, seguidos de uma coda ${ }^{82}$.

Com o surgimento de novas correntes no início do século XX, como a dança moderna, buscou-se a autonomia e a independência da dança, principalmente no que diz respeito à música. Aos poucos, a música foi se distanciando da gestualidade. Esse movimento, liderado por ícones da dança, como Isadora Ducan, baseou-se no ideal de que, quando não há música sendo executada, o corpo fica livre para se expressar e causar outra impressão. Além de não seguirem a métrica musical à risca, os adeptos da dança moderna acreditam que a partitura musical não basta em si mesma; ela depende do gesto para ser completada.

Outra inovação da dança moderna foi o fato de trazer a música popular para os espetáculos de dança. Nota-se, também, a grande influência do jazz nas composições deste período.

Com o advento da dança contemporânea, alguns instrumentos de percussão são incluídos, até mesmo na própria coreografia. Tambores, tamborim, entre outros instrumentos tornam-se elementos cênicos, valorizando assim o ritmo e as pulsações. Por sua vez, a gestualidade passa a ser executada por meio de improvisações; o corpo do bailarino ganha voz própria, não se submetendo necessariamente à música. Nesse mesmo período surgem as primeiras danças sem acompanhamento musical.

Afinal, em meio a tantos movimentos e ideias novas, perguntamo-nos onde se encaixaria o balé de Roland Petit e a composição de Maurice Jarre. O balé Notre-Dame de Paris segue à risca as características de algum movimento específico? Teria sido a música de Jarre uma composição encomendada? E a coreografia de Petit, ela reflete a relação harmoniosa entre música e dança como na dança clássica ou, ao contrário, a coreografia é desencadeada independentemente da música?

Coreógrafo moderno e ligado às principais personalidades de seu tempo, Roland Petit não se importava em seguir contra as correntes em voga. Vale salientar que a

\footnotetext{
81 Palavra derivada do termo italiano adagio, o qual significa lentamente ou com descanso. Em espetáculo de dança, refere-se a abertura do clássico pas de deux no qual a bailarina, ajudada pelo parceiro masculino, executa os movimentos lentos e o bailarino levanta, sustenta ou transporta a bailarina. ${ }^{82}$ No balé, este termo possui dois significados, a saber: 1)Final de um balé clássico no qual todos os solistas aparecem separadamente ou com seus parceiros; 2) A dança final de um clássico pas de deux, pas de trois ou pas de quatre.
} 
década de sessenta foi um período marcado por diversas mudanças nos meios políticos e sociais, as quais reverberaram diretamente no meio cultural. Na música, surge um movimento de massa, no qual bandas como Beatles e Rolling Stones se destacavam. Em 1965, ano de criação de Notre-Dame de Paris, são lançadas músicas de sucesso dessas bandas como Yesterday dos Beatles e Sastisfaction dos Rolling Stones.

Em meio a todos esses movimentos, Roland Petit mantém-se fiel às suas crenças e convicções. Ele não se deixa levar nem mesmo pela corrente de dança contemporânea, em alta no período, a qual além de questionar o papel da música na dança, põe em cheque as noções de personagem e narração. Contrariando essa estética, Petit cria balés com estórias narrativas de fácil compreensão e com personagens bem definidos.

Roland Petit também apresentava um posicionamento bem definido em relação ao binômio dança e música. Para ele "a coreografia deve estar em osmose com a música. Conduzir a dança independentemente da música é se privar de uma grande felicidade, pois a música e a dança são uma coisa só." ${ }^{83}$

Para Notre-Dame de Paris, Petit encomenda, inicialmente, uma partitura original ao compositor grego Prodromides. Entretanto, ele desiste de tal trabalho devido às várias intervenções e sugestões do coreógrafo.

Inicialmente, dirigi-me a um jovem compositor grego. Entretanto, após escutar o que ele me propunha, senti-me contrariado. Tentei lhe falar, explicar-lhe que aqui queria algo mais lento e em outros momentos, ao contrário, algo mais ritmado. Tudo que ele me respondeu foi que ele não tinha nada a ver com Georges Auric, o qual lhe havia passado essa encomenda, uma vez que Auric era um compositor nulo... Eu retorqui: "Tudo bem. Auric é nulo, eu também sou nulo, todos somos nulos. Então anulemos esse contrato." ${ }^{\prime 4}$

Então, Petit decide convidar Maurice Jarre, importante compositor francês, conhecido principalmente por seus trabalhos no cinema, com diversas trilhas sonoras compostas especialmente.

Pensei em Maurice Jarre que havia escrito para mim a partitura de Chants de Maldodor e que havia conhecido na casa de Jean Villar. (...) Eu lhe telefonei em Los Angeles onde ele trabalhava na trilha do filme Lawrence da Arábia.(...) Meu projeto o interessava e ele propôs enviar-me uma folha de partitura por dia. Entretanto,

\footnotetext{
${ }^{83}$ PASTORI. 2003, p. 117 (tradução nossa).

${ }^{84}$ Idem; p. 117 e 118 (tradução nossa).
} 
houve um problema no final. Naquele momento ele estava completamente absorvido por seu filme. Então, com sua autorização, eu pedi ao chefe de orquestra da Ópera de Paris se ele poderia terminar a composição. Juntos, decidimos concluir Notre-Dame de Paris com percussões, uma maneira de eletrizar o palco. ${ }^{85}$

A fim de orientar a composição de Jarre, Roland Petit repassa ao compositor a duração aproximada de cada sequência coreográfica que ele havia pensado, bem como a quantidade de quadros em cada ato. Assim, em Notre-Dame de Paris observamos que a música é concebida em razão da coreografia. Contudo, é importante ressaltar que a música neste balé não tem apenas a função de acompanhar os movimentos executados pelos dançarinos; ao contrário, ela colabora para a concepção da obra. De acordo com Anna Chirescu (2009, p.54), “a música de Jarre é um contraponto à imagem, permitindo expressar aquilo que a imagem não sugere".

\subsubsection{A escritura musical de Maurice Jarre}

Ao agregar sentido à gestualidade criada por Roland Petit, a música de Maurice Jarre torna-se fator essencial para a construção da narrativa coreográfica. Sua função perpassa desde o preenchimento espacial, criando ambientes; ao aumento da carga de dramaticidade aliada ao gesto. Para tais finalidades, Jarre lança mão de diferentes técnicas e elementos, como o leimotiv, o uso de instrumentos musicais inusitados para um balé e, até mesmo, a participação de um coro. Assim, para entendermos a relação estabelecida entre a música e a dança em Notre-Dame de Paris, faz-se necessário a análise detalhada desses elementos.

Técnica criada pelo compositor alemão Wagner, o leimotiv consiste no uso de um ou mais temas destinados a caracterizar um personagem, uma situação, um estado de espírito e que, na forma original ou por meio de transformações desta, acompanha os seus múltiplos reaparecimentos ao longo de uma obra. Apesar de ser um recurso próprio da ópera, podemos notar sua utilização por Jarre para a caracterização de certos personagens, bem como para a composição do adágio amoroso entre Esmeralda e Quasimodo.

A primeira aparição de Quasimodo em cena ocorre durante o quadro Fête des Fous (Festa dos Loucos), por volta de seis minutos após o início do balé. Quasimodo surge em meio ao corpo de baile, no centro do palco, usando um figurino bege,

\footnotetext{
${ }^{85}$ PASTORI. 2003, p. 118 -119 (tradução nossa).
} 
destacando-se assim da multidão colorida. Sua posição corporal evidencia sua deformidade bem como sua diferença em relação aos demais. Enquanto Quasimodo esboça seus primeiros passos, o corpo de baile permanece imóvel em torno dele, em misto de fascínio e estranhamento. Neste momento, a música é fator essencial para a transmissão destes sentimentos ao público. O som grave do violoncelo corrobora para a criação da dramaticidade da cena, evidenciando o lado grotesco do personagem e contribuindo para a sensação de estranhamento que a aparição de Quasimodo provoca na multidão. Tanto que essa música se torna o leimotiv do personagem aparecendo em outros momentos dramáticos do balé, como na cena em que Esmeralda oferece água a Quasimodo.

À medida que a cena avança, nota-se que, apesar da deformidade do corpo de Quasimodo ser evidente, ele não é apresentado como um ser monstruoso que aterroriza a todos. A delicadeza de seus movimentos desajeitados, aliada à expressão de medo e ternura em seu rosto contrastam com sua figura disforme. Essa dualidade trágica, característica do personagem tanto no romance quanto na dança, é reforçada também pela música. Aos poucos, a gravidade inicial do violoncelo se desfaz, tornando a música (ainda tocada pelo mesmo instrumento) suave e melódica. Ao criar duas sonoridades tão diferentes com o mesmo instrumento e que representam o mesmo personagem, Jarre consegue, de certa forma, recriar a dualidade de Quasimodo através da música, mostrando que, da mesma forma que o personagem, um instrumento pode imprimir ritmos totalmente distintos; provocando diferentes recepções no espectador.

É interessante salientar que toda essa sonoridade musical criada para Quasimodo desde o momento de sua aparição, rompe com a cadência frenética da música da sequência anterior: a celebração. Nesta cena, que remete à Fête de fous (Festa dos Loucos) e a eleição do papa dos loucos, a música forte é acompanhada pelos badalos dos sinos, assim como pelos movimentos efetuados pelo corpo de baile. Os bailarinos executam movimentos sincronizados, batendo os pés e as mãos no palco, fazendo de seus corpos instrumentos de percussão, os quais acentuam o ritmo musical.

A introdução desse recurso sonoro em um balé neoclássico ${ }^{86}$ representa uma das grandes inovações de Maurice Jarre e Roland Petit, uma vez que a percussão corporal é

\footnotetext{
${ }^{86}$ Este estilo de dança é caracterizado por incorporar linhas e elementos provenientes da dança clássica, porém pode divergir dessa estética ao incluir mãos e pés flexionados, contrações, ombros curvados, formações não convencionais de dançarinos e grupos de muitos bailarinos desempenhando coreografias diferentes ao mesmo tempo.
} 
característica da dança contemporânea. O uso dessa técnica contribui para a sensação de força da multidão, presença marcante na obra de Victor Hugo, que, em seguida, contrasta com a lentidão e estranheza do leimotiv de Quasimodo. Essa marcação da diferença entre Quasimodo e os demais também fica clara ao final de sua sequência, na qual a música melodiosa termina, cedendo, mais uma vez, lugar ao ritmo acelerado da multidão.

Outro personagem caracterizado por um leimotiv no balé é o padre Frollo. No quadro intitulado La prière (a Oração) ele aparece para lembrar ao povo que a vida não é feita só de prazeres e de festas; que deve haver um momento para a oração e para o arrependimento. Logo, seu solo remete a uma celebração religiosa. Enquanto executa uma sequência coreográfica de saltos, o corpo de baile permanece ajoelhado, realizando todos os movimentos nessa posição, como se rezassem pela clemência divina. $\mathrm{O}$ ambiente solene da cena é reforçado pela música, na qual predomina o som imponente de um órgão, instrumento típico utilizado em cerimônias religiosas. Ademais, nota-se também o acompanhamento de uma espécie de coro religioso. Esses recursos inusitados para um balé e característicos da religiosidade de Frollo aparecem em outras cenas nas quais essa característica do personagem é ressaltada.

Além de acompanhar o bailarino em cena, o leimotiv pode aludir metaforicamente a um determinado personagem, ou ainda, a certos sentimentos, como a paixão. Em meio a música religiosa do solo de Frollo, ouve-se o som de um tamborim, prelúdio da presença de Esmeralda. Nesse momento, uma das mãos de Frollo se solta da posição de oração - característica de seu personagem - e vibra no ar quase que automaticamente ao som deste instrumento. Parece uma pulsão incontrolável. Ele tenta segurar sua mão, mas não consegue controlá-la. Aos poucos, à medida que o ritmo da música acelera, todo o corpo de baile começa a realizar o mesmo movimento, como se enfeitiçados pelo tamborim da jovem cigana, que, até então, não apareceu diante dos espectadores. O único personagem em cena que não é contagiado por este movimento é Quasimodo, que permanece imóvel no canto do palco. Tal imobilidade poderia, por conseguinte, ser entendida como a representação da surdez do personagem. No quadro seguinte - intitulado Esmeralda - a personagem surge em cena, tornando a referência musical mais explícita. 
O som do tamborim, acompanhado do vibrar das mãos de Frollo, torna-se tema também da paixão que Esmeralda desperta no padre. Toda vez que ouve tal instrumento, Frollo é automaticamente possuído pelo ritmo. Ele esquece a sua função clerical se deixa dominar pela paixão incontrolável que nutre pela jovem cigana. No segundo ato, durante o quadro La mort (A morte), o mesmo tema ressurge, marcando a fatalidade que conduz a paixão de Frollo até a morte. Na sequência, Esmeralda é enforcada, ao mesmo tempo em que, Quasimodo estrangula Frollo. Nesse momento, ouve-se mais uma vez o toar do tamborim, que aos poucos vai desacelerando, até o instante em que cessa e Frollo cai desfalecido no chão.

O emprego do leimotiv, assim como a inserção de instrumentos atípicos em um balé não agradou a crítica francesa à época da estreia do espetáculo. Para eles, a partitura de Maurice Jarre, composta em tempo recorde, não era adequada para a dança. Grande parte da imprensa considerou sua composição extremamente hollywoodiana, exagerada, sendo mais apropriada para um filme do que para um balé.

O que dizer da partitura de Maurice Jarre? Nada, ou melhor, quase nada. Não é uma boa música para a cena. Ela contém apenas dois ou três efeitos banais. No mais, ela não encanta, não convence. ${ }^{87}$

Alguns críticos chegaram ao ponto de definir a música de Jarre como patética, sendo uma das únicas partes criticadas do balé. Ademais os juízos de valor da crítica francesa, fato é que a música de Jarre é de suma importância para a composição de um todo de sentido em Notre-Dame de Paris. Viva e colorida, perpassando desde os temas populares até o religioso, a música de Jarre não apenas acompanha a coreografia de Roland Petit; ela colabora, juntamente com os outros elementos, a compor o espetáculo.

\subsection{Do figurino}

Outro elemento importante para a constituição do sistema de significados da dança é o figurino. Além de caracterizar o bailarino como determinado personagem que está sendo representado, em cena, o figurino também é responsável por auxiliar na definição da gestualidade; na identificação de certa época ou período e, ainda, diferenciar certos estilos de dança. Logo, essa outra escritura merece uma abordagem aprofundada em nosso trabalho.

\footnotetext{
${ }^{87}$ COQUELLE. Jornal La tribune Libre, 1966.
} 
Ao se pensar no figurino de um espetáculo de dança, devemos não apenas considerar as roupas utilizadas pelos bailarinos, mas os acessórios que compõe o todo, como: sapatilhas, adereços de cabelo, maquiagem, perucas, joias, objetos cênicos leques, varinhas de condão, etc.

De acordo com Pavis, as grandes funções de um figurino são:

[...] a caracterização (meio social, época e estilo), preferências individuais, a localização dramatúrgica para as circunstâncias da ação, a identificação ou o disfarce da personagem, a localização do gestus global do espetáculo, ou seja, da relação da representação, e dos figurinos em particular, como universo social. ${ }^{88}$

Portanto, ele não deve ser considerado apenas um simples acessório. Assim como a música, o figurino passou por diversas evoluções ao longo do tempo e dos estilos de dança. Na dança clássica, por exemplo, ele tinha a função de reiterar o personagem elaborado pelo libretista. Esse carácter anedótico das vestimentas facilitava a compreensão, por parte do público, quanto à época, o estilo e a classe social dos personagens sem, no entanto, perder a caracterização própria de um espetáculo de dança. Nesse movimento, era comum as bailarinas portarem longas saias, as quais cobriam praticamente todo o seu corpo, além, lógico, das sapatilhas de ponta que favoreciam os movimentos verticais. Por sua vez, os bailarinos usavam roupas de malha coladas ao corpo, o que evidenciava o seu físico e o seu trabalho muscular. Como não calçavam a sapatilha de ponta, os bailarinos optavam por realizar grandes saltos, a fim de reiterarem a verticalidade característica da dança clássica.

Já a dança moderna prezava em evidenciar o corpo como personagem. Logo, ela é composta por figurinos mais simples, os quais permitem movimentos mais soltos, fora da verticalidade da dança clássica. Essa necessidade de libertar o corpo de tudo que o aprisiona, particularidade da dança moderna, é reiterada pelo uso de sapatilhas de meia ponta, o que permite uma movimentação mais horizontal.

\section{Segundo Trotta,}

A ausência de sapatilhas e a afirmação dos pés descalços não mais obrigam à verticalização da gestualidade. $O$ pé no chão aumenta a base de contato com o solo e sugere uma descida para o nível médio. O pé no chão acaba também com a noção de faz-de- conta e dá à movimentação ares de realidade. ${ }^{89}$

\footnotetext{
88 PAIVA apud TROTTA; p. 160.

${ }^{89}$ TROTTA. 2011, p. 168.
} 
Além disso, observa-se a introdução do nu na dança, muitas vezes representado pelo o uso de collants cor da pele. Ao contrário do que muitos pensam, a nudez em cena não marca uma ausência, mas sim a introdução de uma proposta moderna de figurino que permite a liberdade dos movimentos.

Por fim, a dança contemporânea traz o corpo como o lugar dos acontecimentos, caracterizando não mais o personagem, mas cenas reais. Assim, é comum o uso de roupas cotidianas como figurino. Essa escolha por elementos do dia a dia concerne não apenas o figurino, como a música, a composição do cenário e, acima de tudo, a gestualidade.

Portanto, cabe-nos identificar como Yves Saint Laurent concebe o figurino de Notre-Dame de Paris; as técnicas por ele empregadas e as inovações que um estilista da alta-costura mundial traz para o figurino de cena.

\subsubsection{A escritura de Yves Saint Laurent}

Entre as diversas novidades que Roland Petit incorpora ao mundo da dança, está o fato de escolher um estilista de alta costura para desenhar seus figurinos. A parceria entre ele e Yves Saint Laurent começa, na verdade, em 1959, quando Saint Laurent desenha todo o figurino do balé Cyrano de Bergerac. Tal encontro repete-se nos anos subsequentes, nos balés Les Forains (1961), Adage et Variations (1965) e Le diable amoureux (1965).

Para o figurino de Notre-Dame de Paris, Saint Laurent teria buscado inspiração na Idade Média, período da narrativa hugoana. Entretanto, seus figurinos são modernos e apresentam certa leveza, a qual acompanha os movimentos dos bailarinos. O único figurino destoante deste padrão é o utilizado pelas damas da nobreza no primeiro quadro do balé. Neste, o corpo de baile desfila pelo palco em longos vestidos preto e branco, com chapéus que nos remetem à imaginário feérico. 


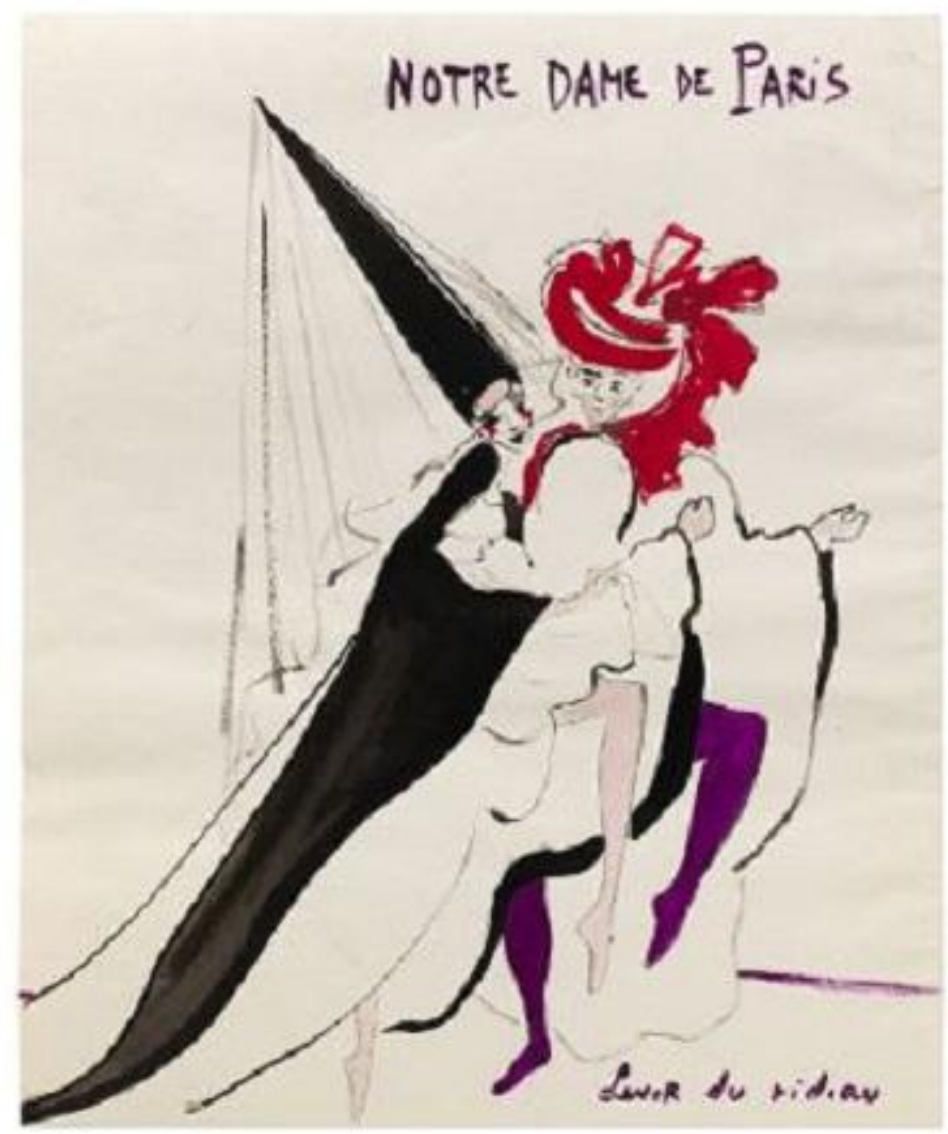

Figura 5 - Yves Saint Laurent. Le lever du rideau ( O levantar das cortinas). 1965

Como dito anteriormente, para os demais personagens Yves Saint Laurent pensou em algo mais moderno e mais fluído:

$\mathrm{Eu}$ tentei acompanhar a juventude atemporal da coreografia. Essa da variação de Esmeralda, dos pas de deux e pas de trois. Os juízes do tribunal, os movimentos oblíquos da Cour de Miracles, a perturbação de Frollo e a ternura tão emocionante de Quasimodo me inspiraram como um afresco da Idade Média. ${ }^{90}$

Para o corpo de baile durante o quadro A celebração, por exemplo, Yves Saint Laurent parece ter buscado resgatar a força e a diversidade da multidão hugoana. $\mathrm{Na}$ caracterização da individualidade dos diferentes tipos que constituem o povo, o estilista optou por figurinos coloridos compostos por uma malha - calça e corpete - para os homens e vestidos curtos para as mulheres. Tal escolha, além de valorizar a linha clássica dos corpos dos bailarinos, cria uma ambiência bastante plástica e moderna, principalmente para um balé neoclássico. Yves Saint Laurent parece ter utilizado em

\footnotetext{
${ }^{90}$ YVES SAINT LAURENT apud FIETTE 2007, p. 25 (tradução nossa).
} 
alguns detalhes das roupa certa inspiração do imaginário medieval, como o trançado no decote dos vestidos femininos. De fato, o colorido dos tecidos lembram os próprios vitrais da catedral de Notre-Dame.

Quando nós trabalhamos em Notre-Dame de Paris, Petit e eu, não imaginávamos que 30 anos depois, esse balé estaria ainda em cartaz na Ópera de Paris. Desde sua criação, ele foi um sucesso e, hoje, é um clássico. Um clássico da modernidade, da invenção, da imaginação. Eu quis que os figurinos fossem coloridos como os vitrais de uma catedral. ${ }^{91}$

Além de lembrar as cores dos vitrais da catedral e de destacar a individualidade de cada ser que compõe o todo; o colorido dos figurinos do corpo de baile é essencial para marcar a diferença de outros personagens em relação à multidão. Em muitas das cenas, esses figurinos, por exemplo, contrapõem-se ao figurino preto e sóbrio de Frollo e ao figurino todo bege de Quasimodo.

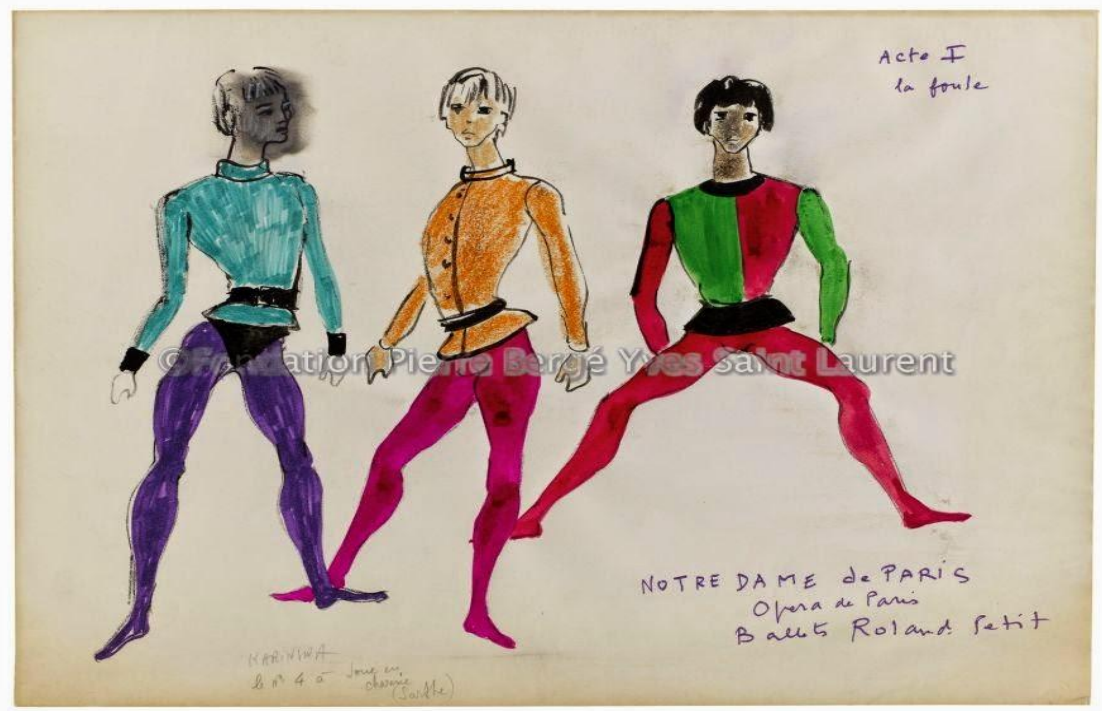

Figura 6 - Yves Saint Laurent. La foule ( A multidão). 1965

Comecemos por Quasimodo. É interessante notar que, desde o primeiro momento de sua aparição em cena, há uma tentativa de se codificar pela vestimenta o carácter ambíguo deste personagem. Na narrativa de Victor Hugo, Quasimodo é, inicialmente, apresentado ao leitor como um caso teratológico, uma mistura de formas humanas e animalescas, que o aproximam de uma criatura bestial. Surdo, com um só olho, coxo e corcunda: eis a primeira descrição desse personagem. Entretanto, no decorrer do texto, percebe-se que este ser monstruoso por sua deformidade física, na

\footnotetext{
${ }^{91}$ YVES SAINT LAURENT apud FIETTE. 2007, p. 25 (tradução nossa).
} 
verdade é dotado de sensibilidade e inteligência, características que se tornam visíveis por meio de seu amor e devoção por Esmeralda.

Ao nos depararmos com este personagem - interpretado no balé com maestria pelo dançarino Nicolas Le Riche - identificamos a personificação da imagem monstruosa que fora criada em nossa mente a partir do texto literário. Sua deformidade bem como sua falta de jeito perante a sociedade que o julga e o exclui, é reconstituída por uma série de elementos, dentre os quais o figurino.

Em sua primeira aparição em cena, Quasimodo surge em meio ao corpo de baile multicolorido, portando uma vestimenta inteiramente bege, composta por uma camisa trançada por um cordão e um collant - vestimenta tradicional da dança clássica. Assim, desde o primeiro momento, fica claro, visualmente, que Quasimodo não pertence à multidão. Sua diferença é bem marcada em relação aos demais. Porém, é interessante notar a escolha do estilista por um Quasimodo menos monstruoso fisicamente que no romance. Yves Saint Laurent e Roland Petit optam por um personagem menos caricato. A corcunda de Quasimodo, por exemplo, é representada pelo bailarino, que durante praticamente todo o balé tem o seu braço esquerdo dobrado e erguido em relação à sua cabeça, criando a sensação de deformidade. As demais características físicas elencadas por Victor Hugo não são recriadas.

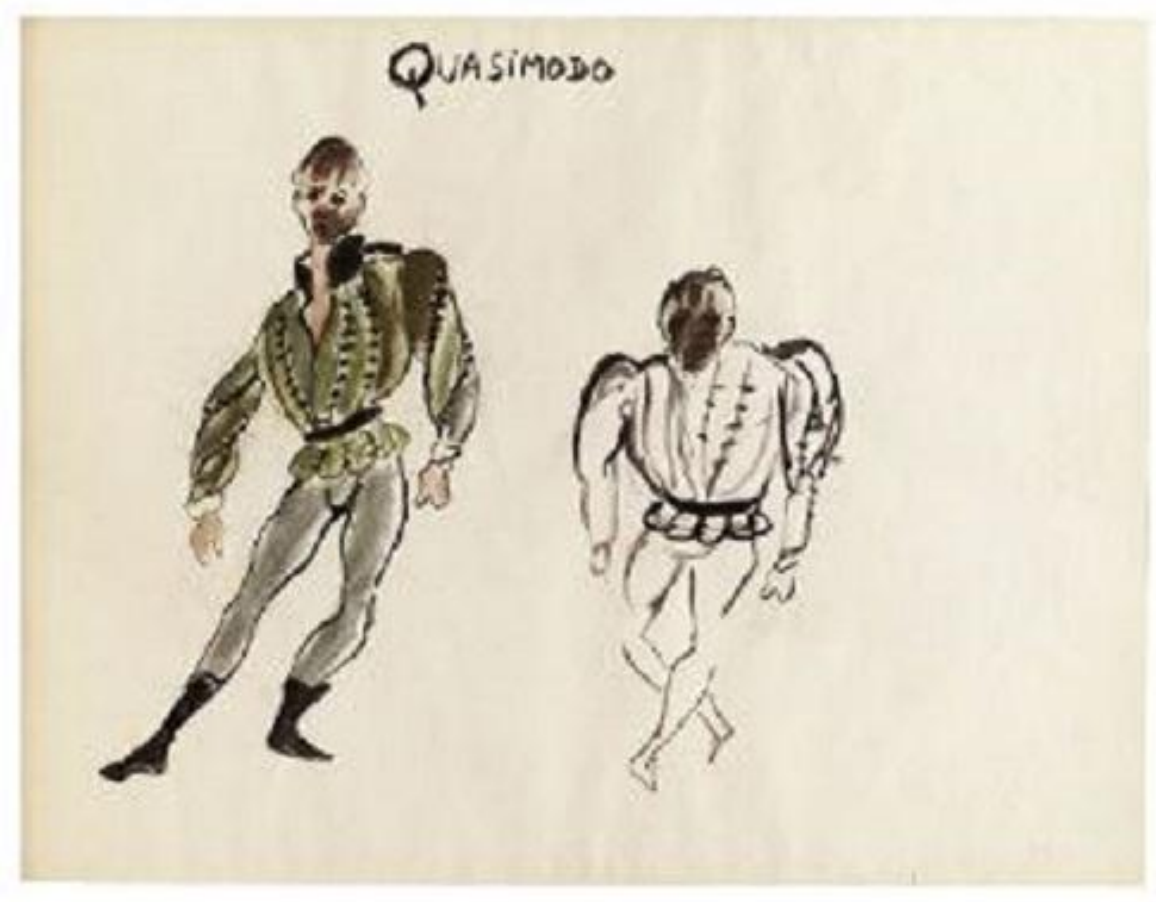

Figura 7 - Yves Saint Laurent -. Quasimodo. 1965 
Talvez, em primeiro momento, ambos tenham pensado em recriar uma face mais monstruosa para Quasimodo, inspirada no célebre filme The Hunchback of Notre-Dame (O Corcunda de Notre-Dame), de 1939, do cineasta alemão William Dieterle. Nessa narrativa fílmica, a caracterização da deformidade física de Quasimodo é feita a partir de uma prótese colocada no rosto do ator Charles Laughton, deixando um lado de seu rosto completamente paralisado, sem vida, como se fosse um irmão siamês falecido, mas indissociável. Tal semelhança na caracterização de Quasimodo pode ser atestada através de uma foto de Petit no papel do corcunda, ilustrativa de um artigo sobre a estreia do balé, em 23 de novembro de 1965, publicado pelo jornal Le Figaro.

No entanto, sabe-se que Petit optou, desde a primeira temporada do espetáculo, pela ausência de uma maquiagem caricata. Essa decisão permitiu que a monstruosidade de Quasimodo fosse metaforizada principalmente pela dança.

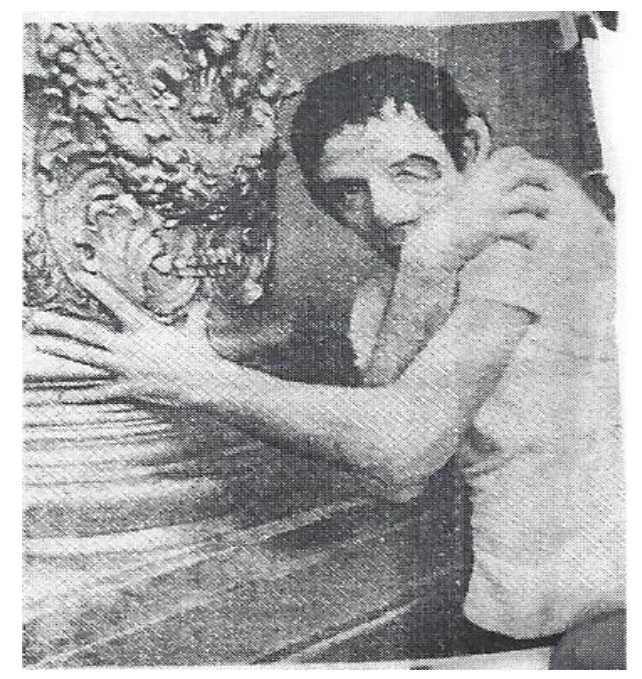

Figura 8 - Charles Laughton no papel de Quasimodo, em The Hunchback of Notre-

Dame, 1939.

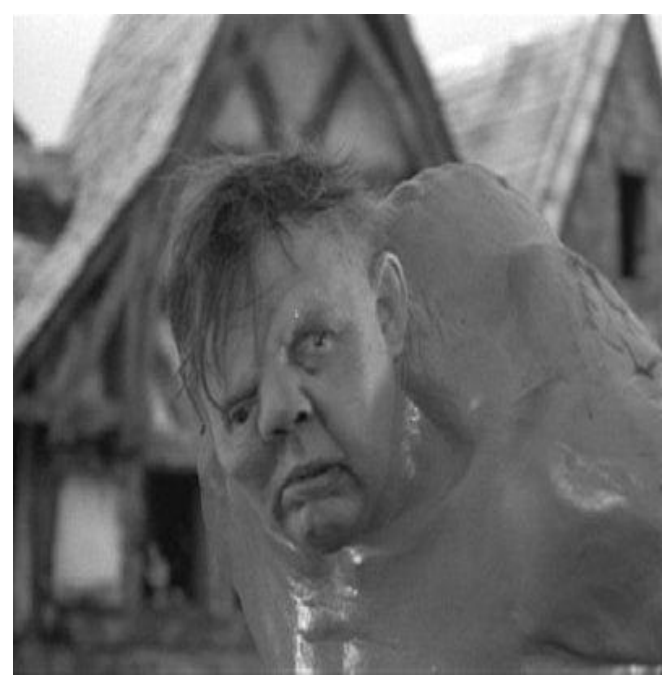

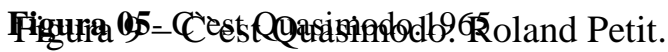
Le Figaro, Paris, 23 nov., 1965 


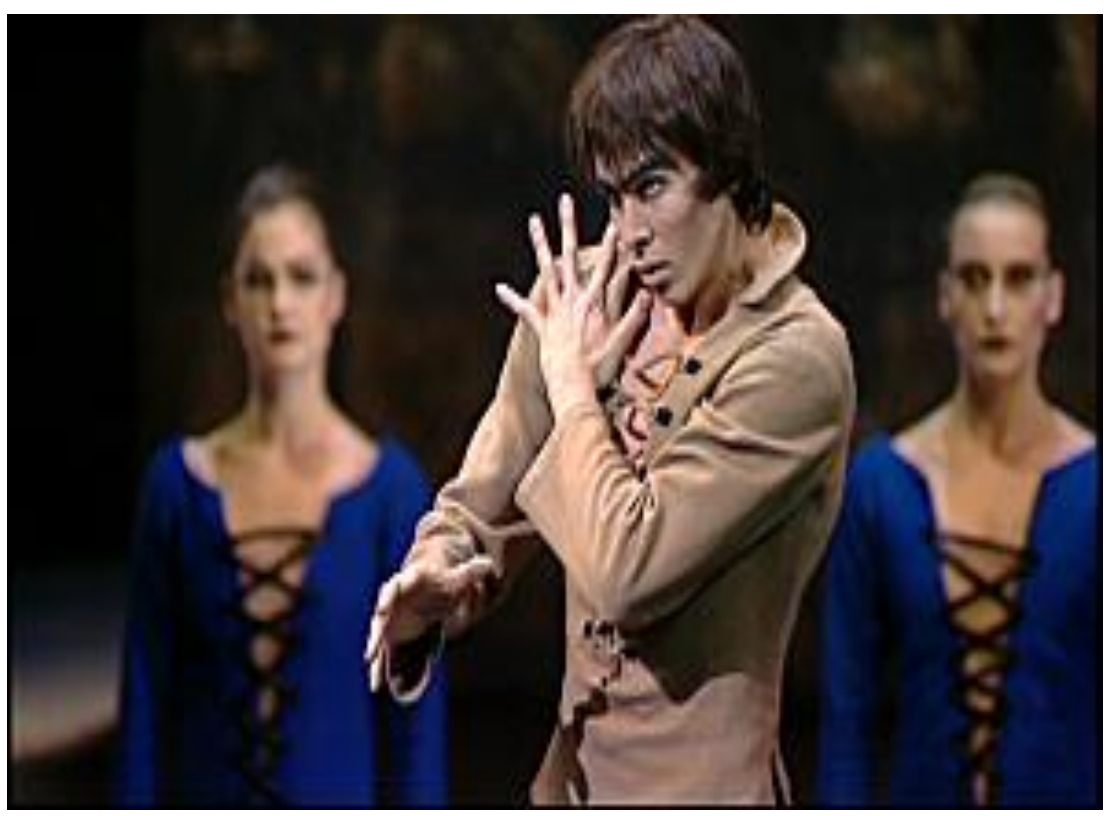

Figura 10 - Nicholas Le Riche como Quasimodo, em Notre-Dame de Paris, 1996

Por sua vez, o clérigo Frollo é descrito fisicamente no romance hugoano como um homem "amargo", "sombrio" e "careca"92. Sua figura envelhecida e imponente causava medo nas crianças e gerava estranheza na população em geral, aumentando ainda mais os rumores de que o padre era, na verdade, um feiticeiro. Já no balé, Frollo aparece caracterizado com uma vestimenta totalmente preta, composta de um collant e uma camisa. Como maquiagem, Yves Saint Laurent propõe uma sombra preta que, como uma tarja, atravessa a face de Frollo. A escolha desse traçado para compor o visual de Frollo poderia ser entendida tanto como uma tentativa de resgatar a descrição hugoana para esse personagem, a qual retrata o padre, por diversas vezes, como uma águia, um tigre que vigia sua presa; quanto uma representação do olhar de desejo de Frollo para Esmeralda. De acordo com Danièle Laster, “o romance insiste bastante sobre o olhar - Frollo que não pode ter contato físico com Esmeralda deve, na maior parte do tempo, contentar-se de tocá-la, acariciá-la ou devorá-la apenas com os olhos."93

\footnotetext{
${ }^{92}$ HUGO, 1831. p. 257

${ }^{93}$ LASTER. 2001. p. 2
} 


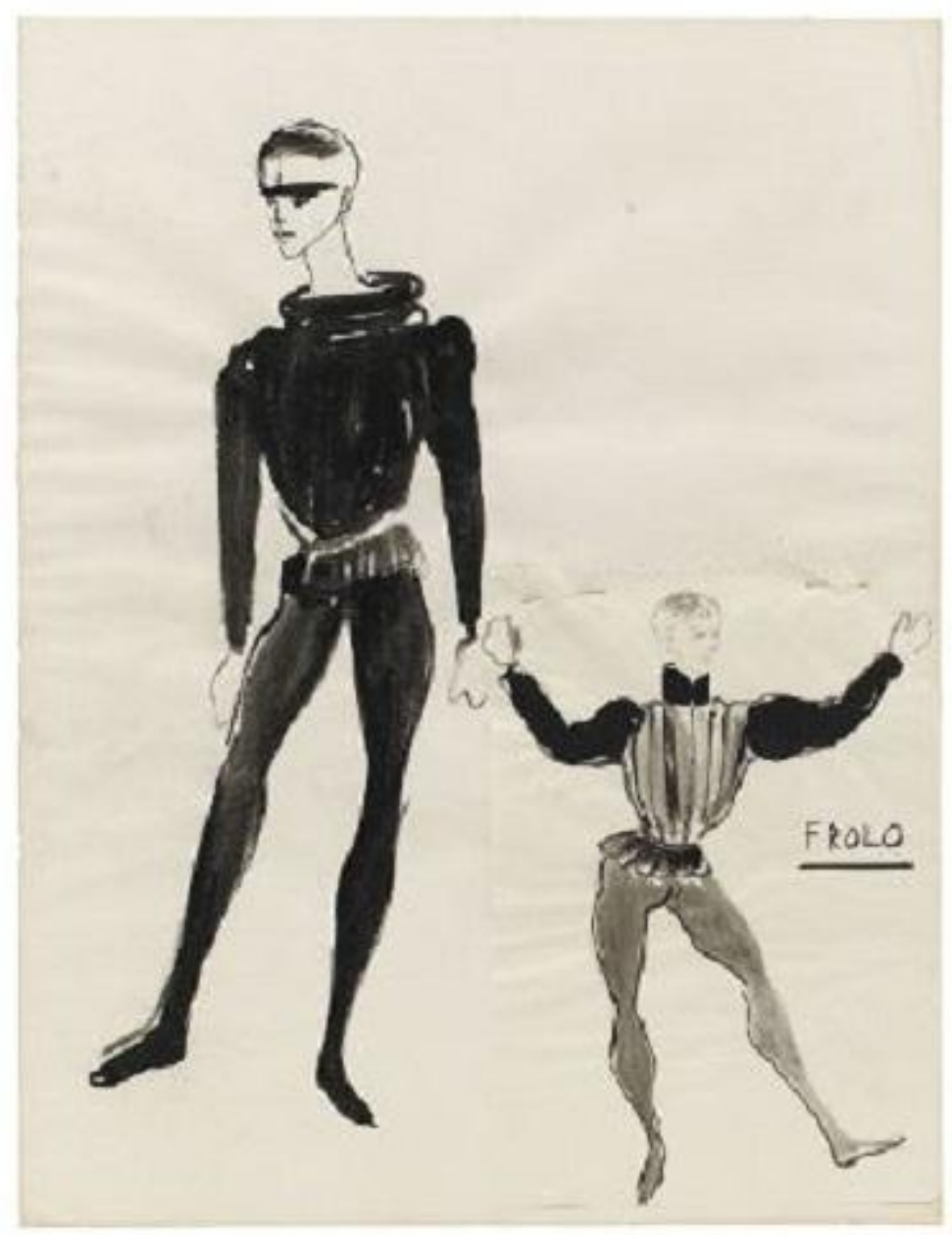

Figura 11 - Yves Saint Laurent. Frollo. 1965

Segundo Chevalier e Gheerbrant, a cor preta carrega consigo diferentes significados:

Simbolicamente, é com mais frequência compreendido sob seu aspecto frio, negativo. Cor oposta a todas as cores, é associada às trevas primordiais, ao indiferenciamento original. [...] Cor da condenação, o preto torna-se também a cor da renúncia à vaidade deste mundo, daí os mantos pretos que constituem uma proclamação de fé no cristianismo. [...]O preto também aparece como cor indicativa da melancolia do pessimismo, da aflição ou da infelicidade... ${ }^{94}$

Logo, podemos supor que tal cor não foi escolhida ao acaso pelo estilista. Além de representar a cor usada pelos homens da igreja no cristianismo, o preto refletiria o

${ }^{94}$ CHEVALIER; GHEERBRANT. 1906, p. 740 e 741. 
caráter sombrio de Frollo e o seu destino fatal e infeliz. Além disso, parece-nos importante lembrar que, de acordo com Barreto, Frollo também integra o elenco de monstros hugoanos, portador de uma monstruosidade de cunho moral. O figurino todo preto valoriza a gestualidade das mãos de Frollo - que denota seu descontrole e obsessão por Esmeralda-, tendo em vista que as mãos são as únicas partes de seu corpo que aparecem. Logo, essa cor também ajudaria a construir sua faceta monstruosa, despertada por seu desejo incontrolável pela cigana.

Objeto da paixão desenfreada de Frollo, Esmeralda é a única personagem no balé a utilizar mais de um figurino. Inicialmente, ela aparece em cena com um bustiê branco e uma saia da mesma cor, amarrada por um cordão preto. Integram ainda a sua vestimenta, quatro braceletes pretos e uma sapatilha de ponta rosa claro. O cabelo, por sua vez, é preso por um coque característico de uma bailarina clássica. 


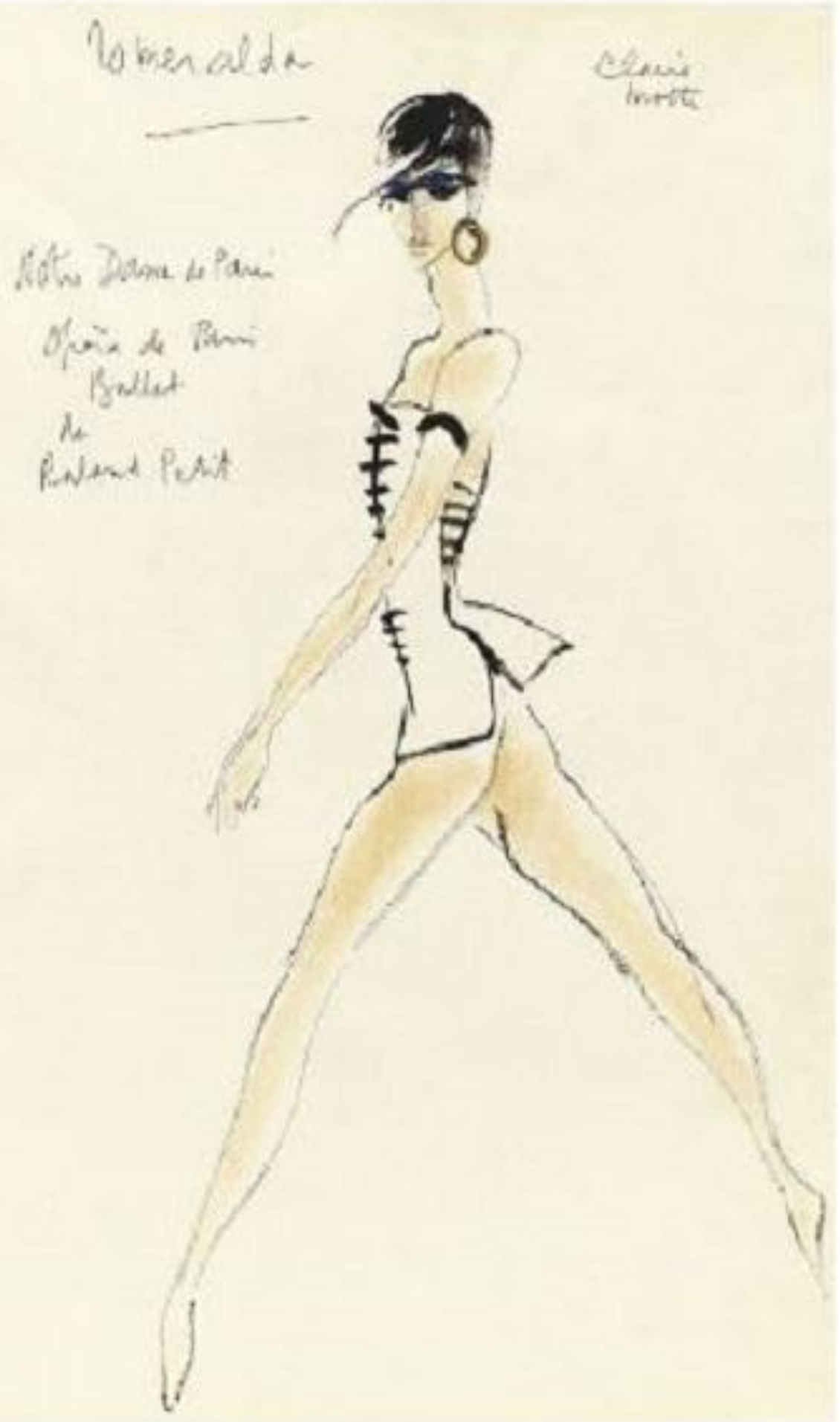

Figura 12 - Yves Saint Laurent. Esmeralda. 1965

Ao analisarmos o croqui acima, é possível perceber que a Esmeralda concebida por Roland Petit e Yves Saint Laurent se difere daquela descrita por Victor Hugo em sua narrativa. Observa-se a tentativa de ambos em construir uma personagem mais 
ousada, diferente da Esmeralda idealizada do romance. Longe do "corpete de ouro" "95, do "vestido colorido que se avolumava"96 e que, em certos momentos, revelava suas pernas finas, ou ainda, de seus "cabelos trançados", o figurino do balé nos revela uma mulher de seu tempo, segura de si, livre e sedutora. Sua personalidade atrevida aproxima-se mais da Carmen de Bizet do que da personagem passiva de Hugo. Todavia, a jovem cigana da narrativa coreográfica não deixa de ser uma personagem dual, apresentando também uma faceta frágil e inocente.

Tal aspecto é ressaltado, por exemplo, pela escolha da cor branca - símbolo de pureza e inocência na cultura ocidental - em um de seus figurinos. Logo, a sensualidade sugerida inicialmente pelo modelo da vestimenta contrapõe-se à escolha dessa cor. Outro acessório responsável por criar essa imagem contraditória no balé é a sapatilha de ponta usada pela dançarina. Esmeralda é a única personagem a utilizá-la; todos os demais bailarinos dançam apenas na meia-ponta. Esse acessório típico dos figurinos do balé clássico imprime um caráter sublime à personagem, além de favorecer uma movimentação vertical, também característica da dança clássica.

Mais adiante, na cena do cabaré, na qual Esmeralda e Phœbus se encontram para uma suposta noite de amor, o lado ousado da personagem expresso através do figurino fica evidente mais uma vez. Nesta sequência, Esmeralda veste um collant cor da pele, sugerindo sua nudez. De acordo com Pavis, "a nudez pode acolher todas as funções: erótica, estética, o estranhamento inquietante, etc. ${ }^{\text {97 }}$ Logo, tal escolha moderna de figurino, considerada uma inovação para um balé neoclássico, reitera a atitude audaciosa dessa Esmeralda.

\footnotetext{
${ }^{95}$ HUGO, 2009 p. 12

96 Idem, p. 12

${ }^{97}$ PAVIS apud TROTTA 2011, p. 166.
} 


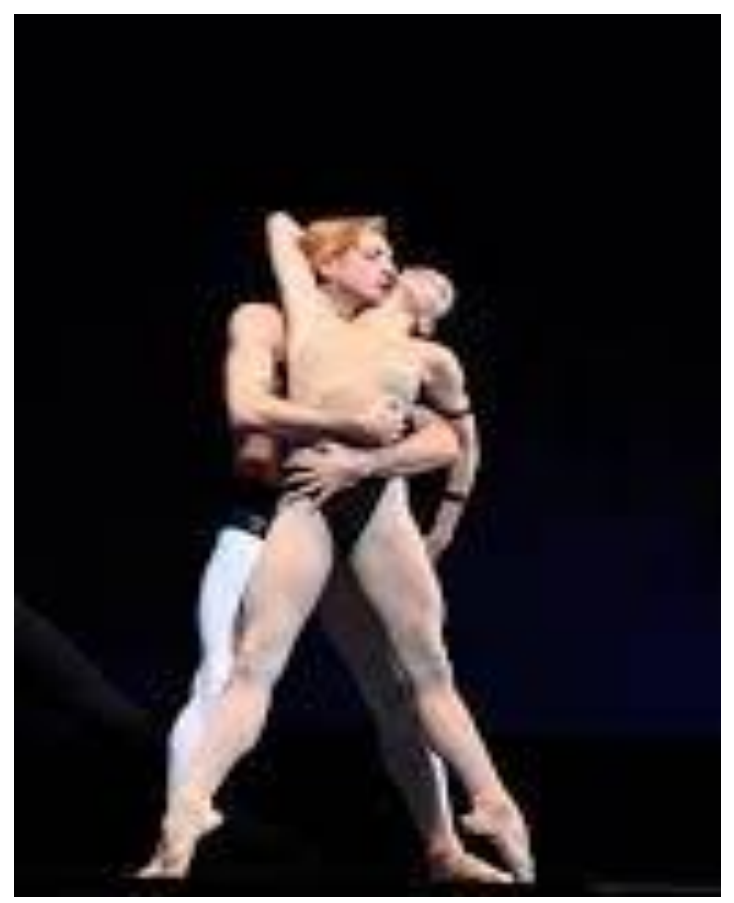

Figura 13 - Isabelle Guerrin no papel de Esmeralda, em Notre-Dame de Paris, 1996

Já no segundo ato, Esmeralda reaparece vestindo a mesma roupa do início, porém roxa. A mudança de cor de seu figurino visa ilustrar não apenas a mudança ocorrida após seu encontro amoroso com Phœbus, mas também a perda de sua liberdade, uma vez que Esmeralda é condenada pela morte de seu amado e, em seguida, fica exilada na catedral de Notre-Dame. Esse figurino em nada lembra o descrito por Victor Hugo nessa passagem do romance, já que a Esmeralda hugoana entra na catedral trajando um vestido e um véu branco.

Por fim, no último quadro do balé, no qual a personagem é enforcada, Esmeralda surge em cena totalmente desolada e fragilizada por seu destino fatal. Essa fragilidade é reiterada pela simplicidade de seu figurino, desprovido de tudo que a caracterizava anteriormente. Nesse momento, ela aparece no palco com o cabelo solto, calçando uma sapatilha de meia-ponta e coberta apenas por um tecido branco - símbolo de sua inocência perante o crime do qual foi acusada.

Para desenhar a roupa de Phœbus, Yves Saint Laurent inspirou-se em seu famoso vestido Mondrian, lançado na coleção de 1965, mesmo ano de estreia do balé de Roland Petit. Assim, o figurino deste personagem é composto de um macacão branco, com mangas pretas e uma cruz de mesma cor que perpassa por todo o tronco do bailarino - igual a do célebre vestido. 


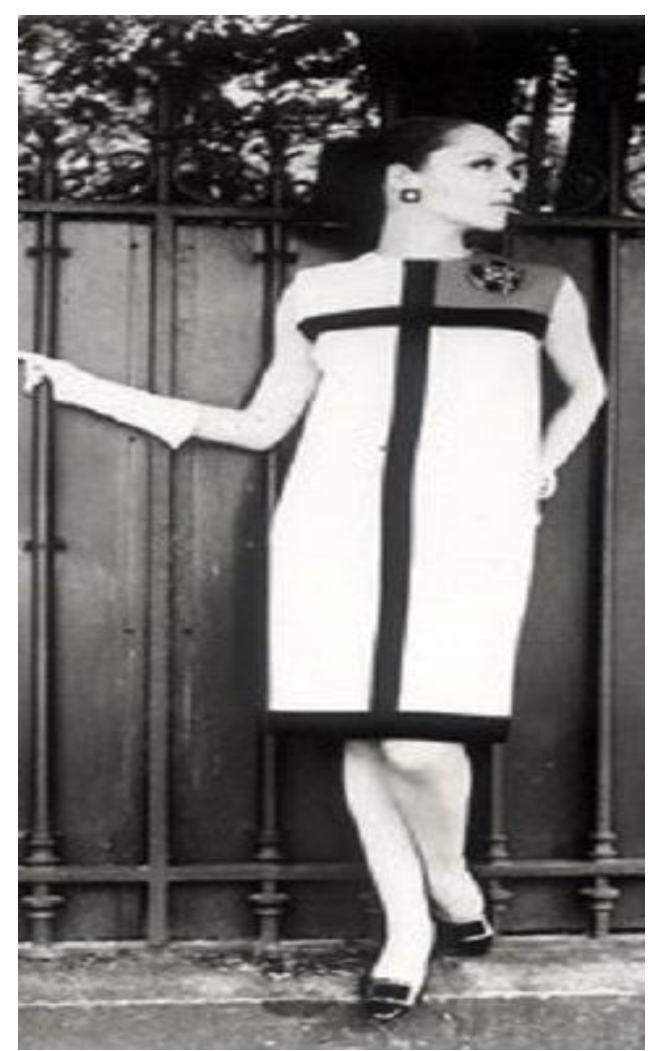

Figura 14 - Vestido Mondrian, por Yves

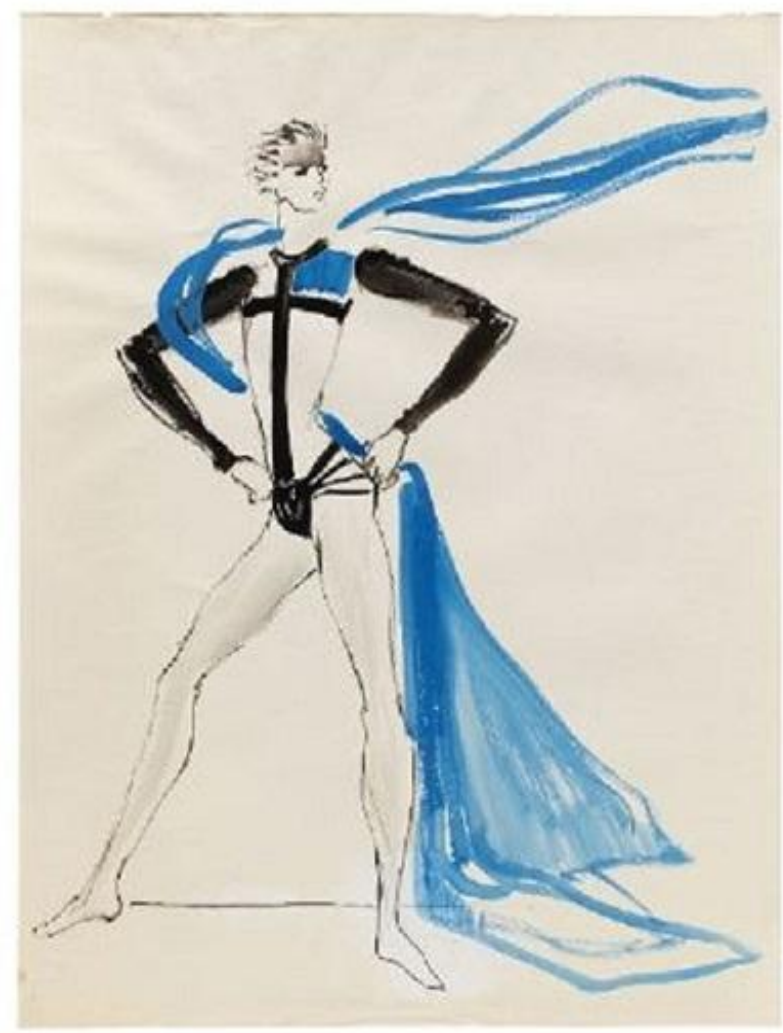

Figura 15 - Yves Saint Laurent. Phøbus. 1965

Saint Laurent. Coleção Outono-Inverno 1965

Integram ainda tal vestimenta, uma capa azul e uma cueca preta vestida por cima do macacão. Esses acessórios, característicos dos super-heróis modernos do cinema e das revistas em quadrinho, como Superman, são responsáveis por criar uma imagem viril para o Phœbus da narrativa coreográfica, tendo em vista que a roupa valoriza seus atributos físicos. Essa virilidade é reforçada pelo desejo que o sedutor Phœbus desperta nas mulheres com quem contracena. Isso fica evidente na sequência do cabaré. Nesta cena, as características físicas das profissionais desse recinto são ressaltadas por vestimentas exageradas - perucas longas e ruivas, próteses que aumentam os seios, etc. Essa representação quase caricata do corpo feminino evoca a luxúria e o prazer carnal, sentimentos dos quais Phœbus é amante. Logo, a caracterização física de Phœbus e de outros personagens com que ele se relaciona é responsável por construir essa imagem de herói sedutor da narrativa coreográfica de Roland Petit. 


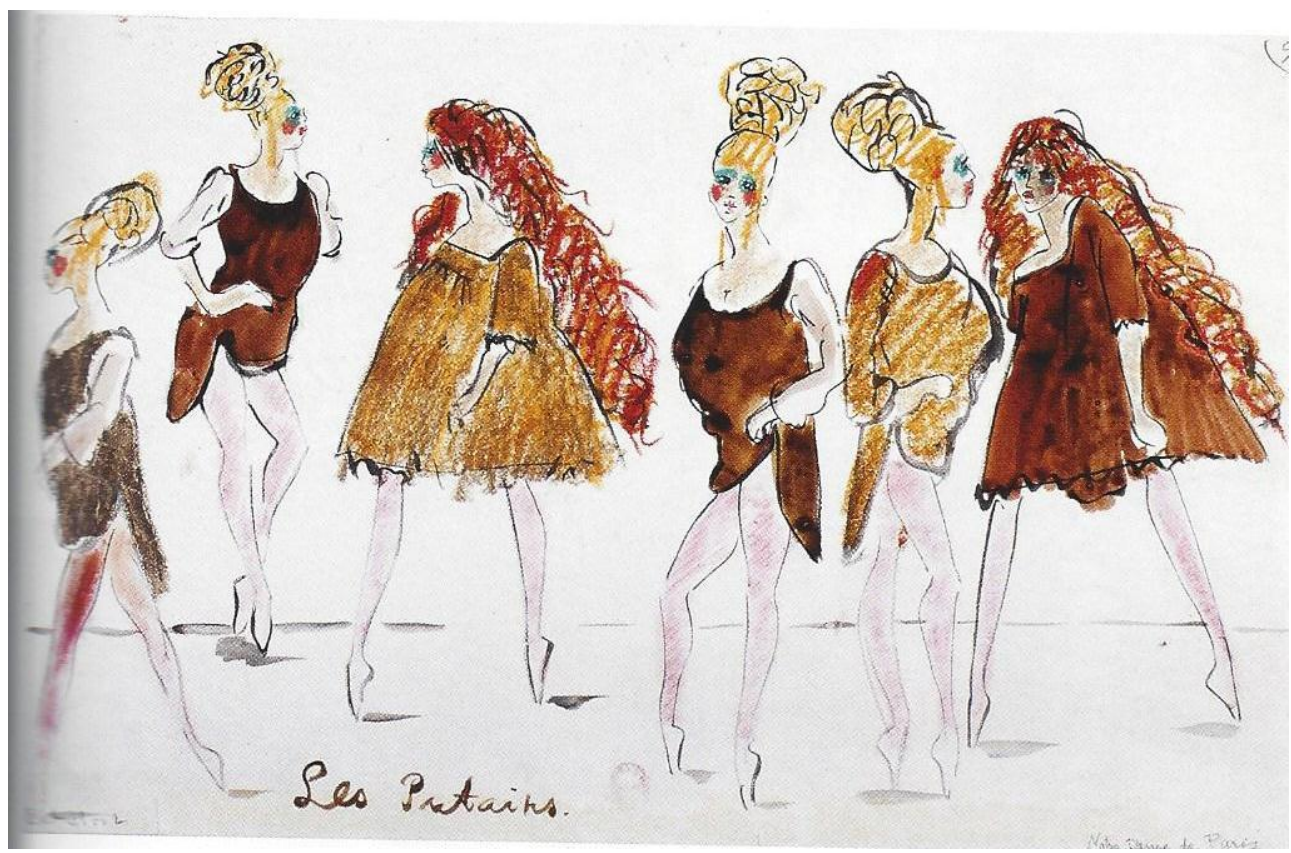

Figura 16 - Yves Saint Laurent. Les putains. 1965

\subsection{Da cenografia}

Assim como os demais elementos retratados, a cenografia é parte fundamental para a construção do texto sincrético que é a dança. Elemento sinestésico que evoca os sentidos da visão e do tato, o cenário tem a função de recriar determinado ambiente e determinada época, transportando o espectador para outra atmosfera.

Compõem o dispositivo cênico, não apenas os objetos em cena, mas também os telões colocados em diferentes planos e, no caso da dança contemporânea, até mesmo a iluminação. Entretanto, ao conceber a cenografia de um espetáculo de dança, o cenógrafo deve pensar detalhadamente no uso e na posição de cada objeto, uma vez que tal projeto deve atender a demandas específicas: o design da cena precisa oferecer um grande espaço vazio para a movimentação dos bailarinos em todas as direções. Respeitada essa necessidade primordial da dança, o cenógrafo consegue criar, então, uma terceira dimensão, onde prevalece a sensação de amplitude e imensidão.

Da mesma forma que no teatro, a cenografia da dança passou por diversas transformações ao longo do tempo. Inicialmente, ela era apenas um objeto estético sem autonomia, de caráter puramente decorativo. No entanto, a partir do instante em que as danças populares foram trazidas para as cortes na Itália e na França durante o século $\mathrm{XV}$, a dança adquiriu a feição de espetáculo e, por conseguinte o dispositivo cênico ganhou importância. Nesse período, as danças eram apresentadas para o rei e sua corte, 
os quais se sentavam de um determinado lado do salão. Na extremidade oposta, geralmente, colocava-se um enorme telão representando o local da ação. O cenário era composto ainda, por carruagens, fontes e jardins; tudo muito luxuoso e exagerado, tendendo para um certo maneirismo.

Quando a dança deixa os palácios e começa a frequentar as salas teatrais, essa maquinaria opulenta é substituída pela pintura de telões e alguns objetos complementares em cena. Entretanto, essas telas pintadas criavam cenários magníficos que compunham a montagem de forma grandiosa. No período clássico da dança, por exemplo, quando predominavam os balés narrativos, a cenografia era composta por elementos figurativos e pomposos, o que reiterava a narrativa. Logo que as cortinas se abriam, o espectador era capaz de identificar os personagens e o ambiente descritos no libreto. Já na dança moderna, com a ressignificação do corpo - o qual passa a ser o lugar de todos os acontecimentos -, a cenografia torna-se cada vez mais sóbria, principalmente no período pós-guerra. $\mathrm{O}$ cenário é praticamente inexistente, uma vez que o destaque deve ser o bailarino e a sua movimentação em cena. Por fim, a dança contemporânea incorpora de vez a economia de recursos cênicos, preenchendo o espaço cênico, muitas das vezes, apenas com a iluminação, aumentando o grau de sincretismo entre as linguagens.

Independente do tamanho, do estilo e do momento histórico, é fato que a cenografia estabelece metáforas interessantes que contribuem para a concepção da obra. Portanto, sua análise detalhada é de suma importância para a compreensão de um espetáculo de dança.

\subsubsection{O cenário de Réné Allio}

Entre os grandes talentos de Roland Petit está a habilidade de transformar clássicos da literatura em produções modernas. No caso de Notre-Dame de Paris, parte dessa modernidade deve-se ao cenário de Réné Allio. Esse cenógrafo consegue tal proeza ao dar um toque cinematográfico à Idade Média hugoana, concebendo, assim, um cenário simples, porém estilizado.

René Allio remete-nos a todo instante ao ambiente medieval de Paris, colocando em cena elementos importantes do romance hugoano como o pelourinho, o universo da Cour de Miracle, e a presença imponente da catedral, a qual é retratada de diversos ângulos. Além desses elementos, integra o cenário uma tela, a qual é mantida como cenário de fundo durante todo o espetáculo. Os traços pretos, tortuosos e imprecisos 
nessa tela transparente evocam o "sombrio labirinto de edifícios" Notre-Dame de Paris.

Em meio a esses cenários, é interessante notar a prevalência da catedral como principal dispositivo cênico do balé. Sua imponente faixada desaparece e reaparece verticalmente em cena, diversas vezes ao longo do espetáculo. Isso é possível graças a um dispositivo que a faz descer e se abrir diante do público. Fisicamente, a catedral imaginada por René Allio conserva alguns dos aspectos que compõem a parte frontal do famoso edifício. Podem-se distinguir as duas torres, alguns arcos em forma de ogiva, um vitral e a porta frontal. Entretanto, qualquer semelhança com o monumento histórico cessa por ai. As diversas estátuas e gárgulas que compõem o edifício não são colocadas em cena. Assim como a tela de fundo, a catedral é desenhada com traços pretos e não retilíneos, os quais compõem a estrutura da construção de forma não harmônica, muito diferente do monumento histórico esculpido em pedra e cheio de detalhes.

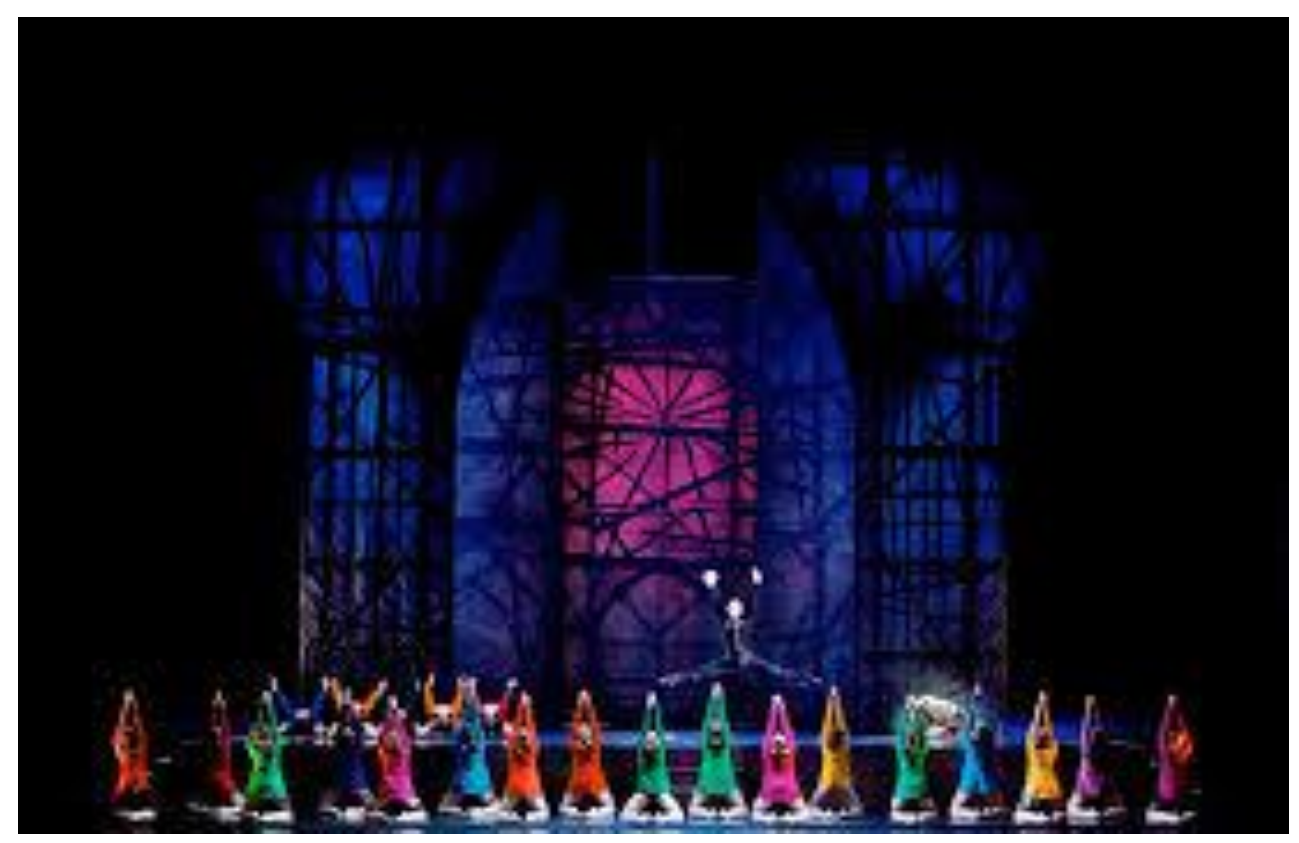

Figura 17 - La prière.em Notre-Dame de Paris, 1996

Essa forma de composição da catedral, apesar de se diferenciar também da "vasta sinfonia de pedra"99 descrita por Hugo no romance, parece remeter-nos para a obra pictórica do autor. Não apenas o traçado, mas as cores escolhidas para a iluminação em muito lembram os desenhos de Victor Hugo. Além disso, a presença massiva desse cenário reconstituindo a faixada frontal de Notre-Dame chama-nos a

\footnotetext{
${ }^{98}$ HUGO, 2009. p. 190 (tradução nossa)

${ }^{99}$ Idem, p. 156
} 
atenção para a presença do $\mathrm{H}$ de Hugo, característica presente na narrativa textual e que de certa forma é resgatada pelo cenógrafo.

Ainda, de acordo com Chirescu, essa forma de traçado sombrio e desordenado, poderia elucidar também, mesmo que metaforicamente, a ideia de fatalidade que na obra romanesca guia os personagens - individuais ou coletivos - para um fim funesto.

\begin{abstract}
De forma abstrata, o cenário sugere a ideia de edifício religioso, ao mesmo tempo que passa a impressão sombria de mau presságio pela negritude de suas linhas e a falta de harmonia no conjunto. Essa seria, talvez, uma maneira metafórica de lembrar o início do romance e a inscrição FATALIDADE sob o qual a obra foi feita. ${ }^{100}$
\end{abstract}

Assim, é possível perceber que alguns dos ideais representados não apenas no romance, mas também na obra de Victor Hugo como um todo, ganham vida na recriação de Roland Petit. Porém, é necessário salientar que, apesar do lugar de destaque desse edifício na narrativa coreográfica, ele não exerce o mesmo papel que o postulado no livro. Em Notre-Dame de Paris, a catedral é um dos grandes personagens da narrativa. Segundo Marie Tapié,

\begin{abstract}
Notre-Dame é mais que um simples cenário, ela é um personagem imortal que vem dar conta das degradações engendradas pelo tempo e pelo homem. Essa ideia retoma o pensamento conservador de Hugo que, usando seu romance como pretexto, segue seu combate pela salvação dos monumentos - iniciado em 1824 - introduzindo um capítulo inteiramente consagrado a esse projeto e intitulado Ceci tuera cela ${ }^{101}$.
\end{abstract}

No balé, a catedral é concebida por Roland Petit como uma construção atemporal, um templo religioso, ou ainda, um lugar de asilo, o qual permite que Esmeralda fique em segurança por certo tempo. Apesar de sua predominância como principal cenário do espetáculo, ela pouco suscita no público o ideal hugoliano de preservação dos monumentos góticos.

Além da vista frontal da catedral, René Allio busca retratar o interior desse templo, como, por exemplo, na sequência de abertura do segundo ato em que Quasimodo balança-se em um grande sino. Essa cena parece-nos novamente inspirada em uma narrativa cinematográfica, dessa vez no filme de Jean Delannoy, em que o personagem de Anthony Quinn realiza o mesmo movimento. Entretanto, é importante notar a relevância dessa sequência assim como desse cenário para a construção da figura

\footnotetext{
${ }^{100}$ CHIRESCU. 2009, p. 40 (tradução nossa)

101 TAPIE. 2000. Disponível em : http://groupugo.div.jussieu.fr/Groupugo/00-12-16tapie.htm\#_ftnref6
} 
dual de Quasimodo proposta por Roland Petit. Na narrativa textual, Quasimodo - o sineiro de Notre-Dame -, é caracterizado por Victor Hugo como parte integrante da catedral. Esse espaço era para ele mais do que uma simples moradia, era seu universo, seu abrigo, seu esconderijo, algo sem o qual ele não sobreviveria. Havia uma harmonia entre ambos. A catedral fazia parte de Quasimodo - " a áspera catedral era sua carapaça"102-, e Quasimodo fazia parte da catedral.

Foi assim que, pouco a pouco, desenvolvendo-se no seio da catedral, ali vivendo, dormindo, não saindo quase nunca e sofrendo, a todo o momento, uma pressão misteriosa, ele chegou a assemelhar-se a ela, a encrustar-se, por assim dizer, a tornar-se parte integrante. ${ }^{103}$

Apesar de sua aparência disforme, a qual o caracteriza como monstro, Quasimodo é um ser sensível, dotado de uma alma boa e generosa. Parte dessa sensibilidade é demonstrada pelo amor que sente pela catedral e seus sinos. Mesmo que eles o tenham deixado surdo, Quasimodo os considera como sua família e estabelece com eles uma relação de amor.

O que ele amava mais nesse edifício maternal; o que despertava sua alma e o fazia abrir suas pobres asas reprimidas em sua caverna; o que o deixava feliz, às vezes, eram os sinos. Ele os amava, acariciava-os, conversava com eles, compreendia-os. ${ }^{104}$

O vínculo amoroso estabelecido entre Quasimodo e Notre-Dame permite ao leitor entrever a beleza e a sensibilidade existentes em seu espírito. Da mesma forma, a sequência de abertura do segundo ato do balé faculta ao espectador esse entendimento. Ao descer pelo sino gigante, Quasimodo demonstra ao público não somente sua função na catedral, mas a sua relação com este edifício. No instante em que o bailarino pendura-se no dispositivo cênico e se balança como se fosse o pêndulo do sino, é possível perceber a vinculação desse personagem a catedral, ele torna-se parte integrante dela.

\footnotetext{
${ }^{102}$ HUGO, 2009. p.247 (tradução nossa)

${ }^{103}$ Idem, p. 247
}

Texto fonte: C'est ainsi que peu à peu, se développant toujours dans le sens de la cathédrale, y vivant, y dormant, n'en sortant presque jamais, en subissant à toute heure la pression mystérieuse, il arriva à lui ressembler, à s'y incruster, pour ainsi dire, à en faire partie intégrante.

${ }^{104}$ Idem, p. 250 e 251

Texto fonte: Ce qu'il aimait avant tout dans l'édifice maternel, ce qui réveillait son âme et lui faisait ouvrir ses pauvres ailes qu'elle tenait si misérablement reployées dans sa caverne, ce qui le rendait parfois heureux, c'étaient les cloches. Il les aimait, les caressait, leur parlait, les comprenait 


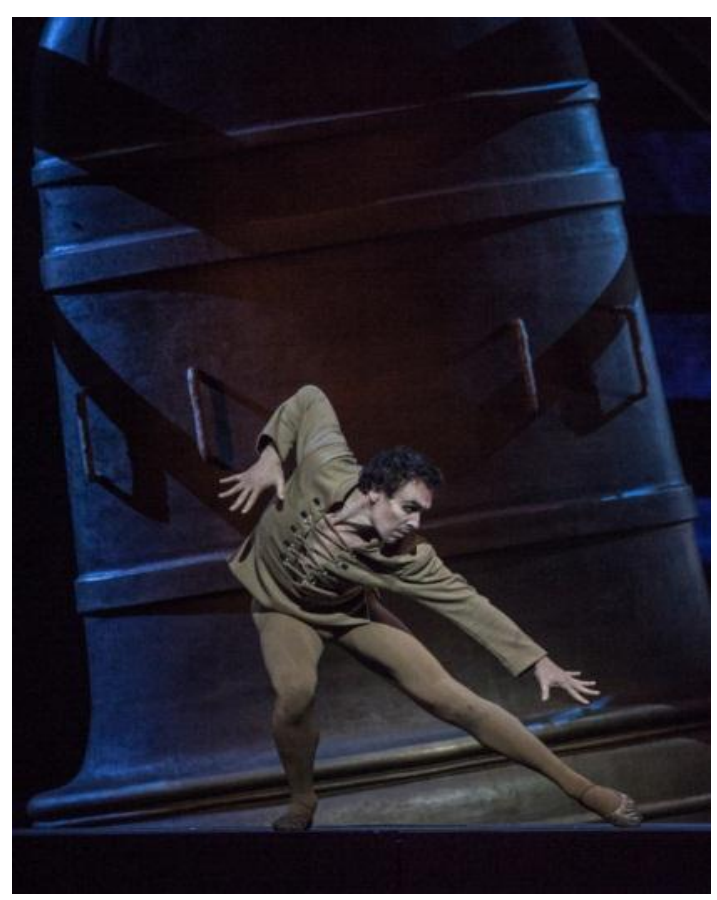

Figura 18 - Le clocher de Notre-Dame. 1996

Outro cenário de destaque do espetáculo é o produzido para o quadro Cour de Miracle, no qual Esmeralda é perseguida por Quasimodo pelas ruelas sombrias “do reino da Cour de Miracles" 105 . "O complicado labirinto de ruelas, cruzamentos e ruas sem saída" ${ }^{106}$ descrito por Hugo ganha vida através de um palco elevado composto por diversas figuras geométricas, as quais dão acesso a um sistema de alçapões, que permite o deslocamento dos bailarinos por debaixo do palco assim como sua entrada em cena pelo meio dele.

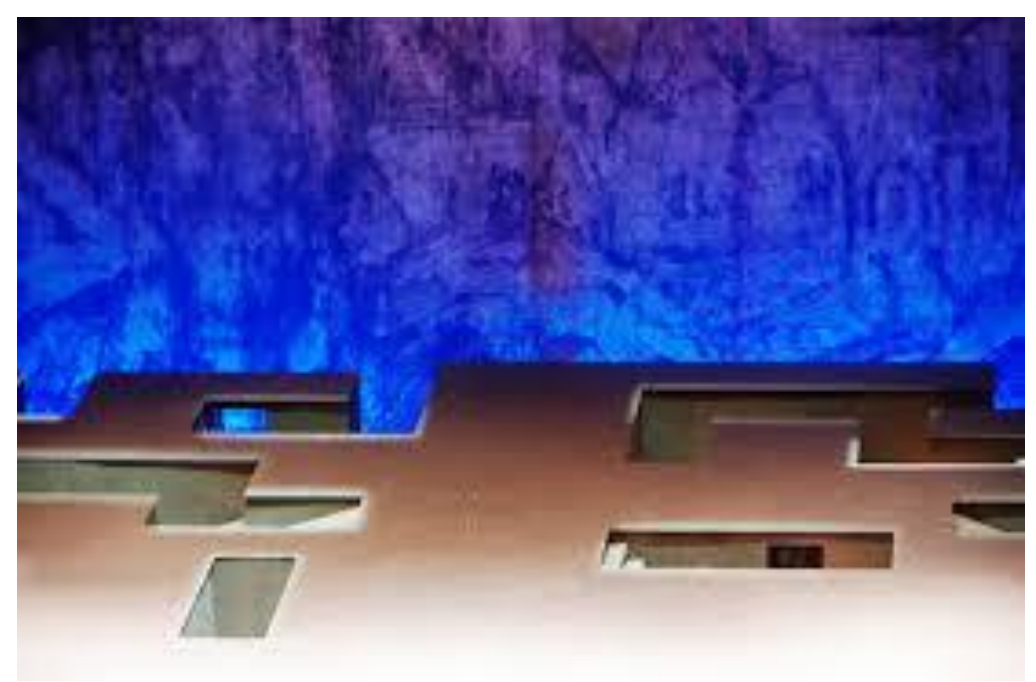

Figura 19 - Cenário do quadro Cour de Miracles. 1996

Essa técnica empregada por René Allio em conjunto com tela de fundo descrita anteriormente e com a iluminação avermelhada cria uma atmosfera infernal, quase que

\footnotetext{
${ }^{105}$ PETIT, Roland. Argumento do ballet Notre-Dame de Paris. 1965.

${ }^{106}$ HUGO. 2009. p. 115
} 
diabólica para a Cour de Miracle. A movimentação do corpo de baile, que sobe rastejando pelos buracos no palco, dá aos habitantes desse lugar - mendigos, malfeitores, enfermos, prostitutas, entre outros - um aspecto praticamente bestial, uma vez que lembram seres rastejantes que saem da profundeza da terra. Assim, na adaptação de Roland Petit, a monstruosidade não se restringe apenas a Quasimodo ou a Frollo, mas estende-se a Cour de Miracle, local povoado por diabos rastejantes, os quais representam a escória da sociedade parisiense da Idade Média.

Ademais, é importante destacar que, ao criar cenários que permitem a interação dos bailarinos com os dispositivos cênicos, Allio traz uma atmosfera bastante moderna ao espetáculo, uma vez que não é própria da dança neoclássica esse tipo de contato.

\subsection{Da iluminação}

Em um espetáculo de dança, a iluminação é muito mais do que uma condição técnica, ela é um elemento significativo. Entretanto, antes mesmo de adquirir esse carácter representativo, a luz acumulou uma série de funções na história da representação cênica, sendo a primeira delas, viabilizar a realização de um espetáculo. A partir do momento em que os teatros deixaram de ser a céu aberto, gerou-se a necessidade de uma luz artificial que possibilitasse o público enxergar o que estava sendo encenado. Logo, tornou-se comum o uso de iluminação artificial no palco, o que possibilitava a visibilidade da cena, ao mesmo tempo em que deixava o público no escuro. Tal mudança permitiu a criação de outro efeito: a separação entre o mundo fictício e o mundo real. De acordo com Pereira,

\footnotetext{
Uma outra mudança significativa na iluminação: a plateia podia agora gozar de uma intensidade de luz bem mais fraca que o palco. Esse recurso facilitou os dois lados: tanto o público tornava-se mais concentrado, já que cada pessoa isolava-se em sua penumbra, quanto novas possibilidades dramáticas puderam ser experimentadas. A ilusão era alcançada através da separação dos dois mundos. ${ }^{107}$
}

A permanência do espectador na penumbra permite que ele perca a noção da realidade que o rodeia e faz com que ele desloque-se para outro mundo, o da ficção. $\mathrm{O}$

${ }^{107}$ PEREIRA apud Trotta, 2010, p. 140 
blackout no início do espetáculo, por exemplo, corrobora para essa transposição entre o mundo real e o mundo da ilusão.

A iluminação torna-se elemento actante e estético, somente a partir do Renascimento, quando surge a iluminação a gás. Ainda segundo Pereira,

A combinação entre iluminação e dança começou a ganhar contornos mais interessantes somente época do Renascimento. Foi nesse período que nasceu o balé e que a iluminação intentou algo mais do que apenas tornar visível, reivindicando tratamentos estéticos mais sofisticados, influindo aqui e ali no acabamento visual da encenação. ${ }^{108}$

Logo, a iluminação cênica passou a representar algo na dança. Portanto, aspectos como tonalidades e os efeitos produzidos pela luz ganharam importância na composição e no estudo de um espetáculo de dança. Como afirma Simões,

Tal qual a música, a luz toca a sensibilidade do público, às vezes imperceptivelmente. A luz veste o espaço com "atmosferas", revelando-o segundo pontos de vista diferentes, assim, dependendo das variações da luz, muda a temperatura, a textura e o clima da cena e isso interfere diretamente no ânimo das personagens e em suas ações, assim como no ânimo do próprio público que assiste à cena. ${ }^{109}$

Consequentemente, como a luz é um fator importante para a composição da narrativa coreográfica, faz-se necessário um estudo detalhado das cores e dos tons escolhidos pelo iluminador, uma vez que elas são responsáveis pelo reconhecimento de certa imagem por parte do espectador, ou ainda, por criar efeitos de aproximação e distanciamento da realidade.

\subsubsection{A iluminação de Jean-Michel Désiré}

A fim de complementar a simplicidade e o aspecto cinematográfico criado por René Allio para o cenário de Notre-Dame de Paris; Jean-Michel Desiré opta pela utilização de cores primárias para a iluminação, as quais se alternam em tons quentes e frios de acordo com a cena.

Entre os tons quentes selecionados pelo iluminador estão o amarelo/ocre e o vermelho. Para o primeiro quadro, por exemplo, Desiré usa luzes em tons de amarelo e

\footnotetext{
${ }^{108}$ PEREIRA apud Trotta, 2010, p. 141

${ }^{109}$ SIMÕES, 2008, p. 71
} 
ocre para compor o ambiente do dispositivo cênico da catedral, durante a Fête de Fous. Essas luzes que saem do fundo do palco e perpassam os contornos de Notre-Dame dão a esse local não apenas forma, volume e profundidade, mas também constroem um aspecto onírico, quase irreal; distanciando o espectador da realidade e conduzindo-o para uma atmosfera de fantasia, a ser contada pela dança.

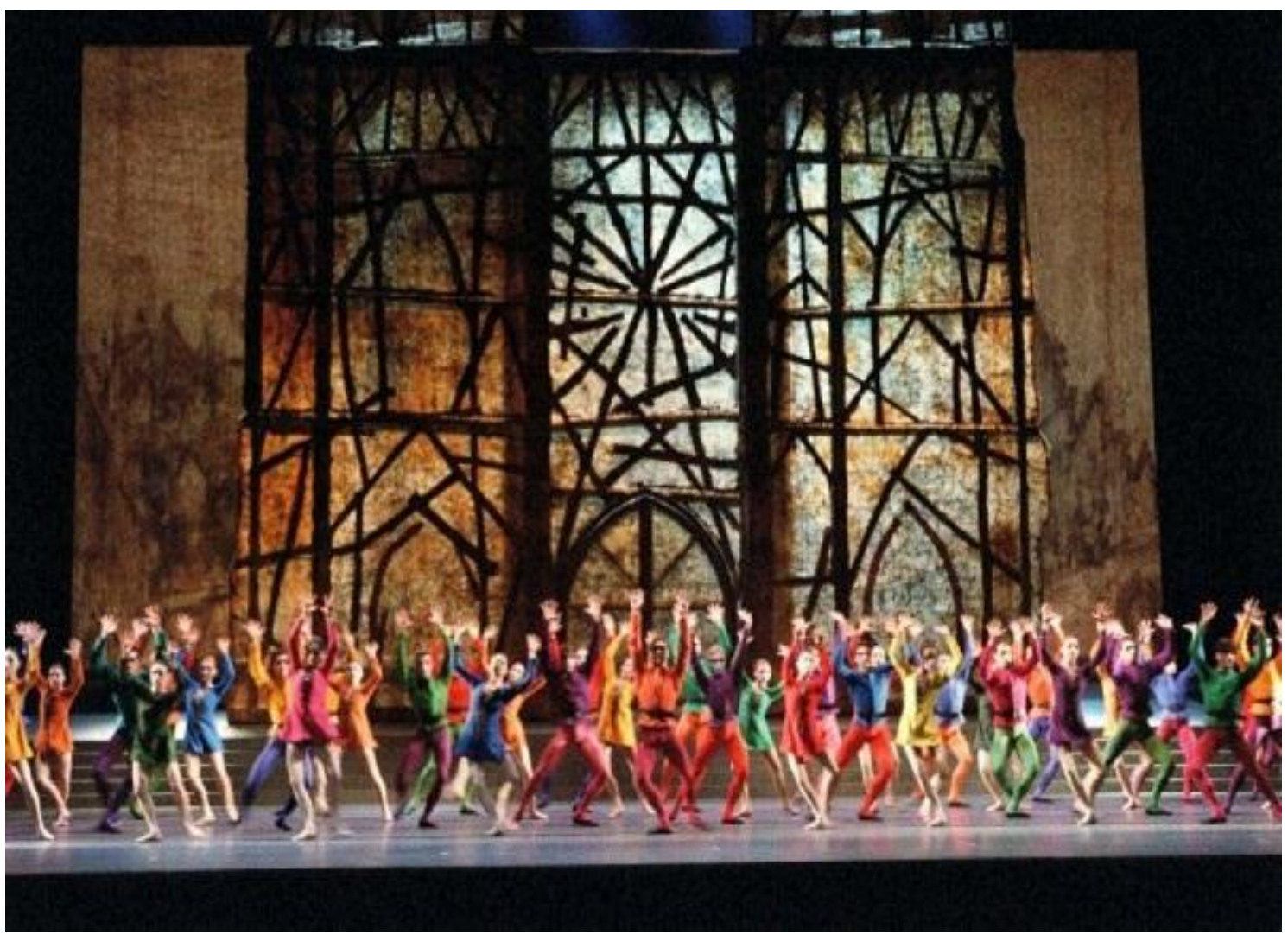

Figura 20 - Fête de fous. 1996

Já para o quadro Cour de Miracle, a fim de reiterar a concepção infernal dada por Roland Petit a esse lugar, Desiré utiliza-se de luzes na cor vermelha. A escolha dessa cor, não é feita ao acaso, tendo em vista que o vermelho é uma cor que sugere excitação e agressividade, além de, claro, remeter metaforicamente ao próprio inferno. Ademais, na própria obra romanesca, Victor Hugo evoca essa cor para descrever tal local: "Na verdade, a Cour de Miracle não passava de um cabaré, porém era um cabaré de ladrões; mais vermelho de sangue do que de vinho." ${ }^{110}$ Portanto, a iluminação aliada ao figurino e ao cenário nessa cena é fundamental para a construção do ambiente diabólico almejado pelo coreógrafo.

${ }^{110}$ HUGO, 2009, p.165 


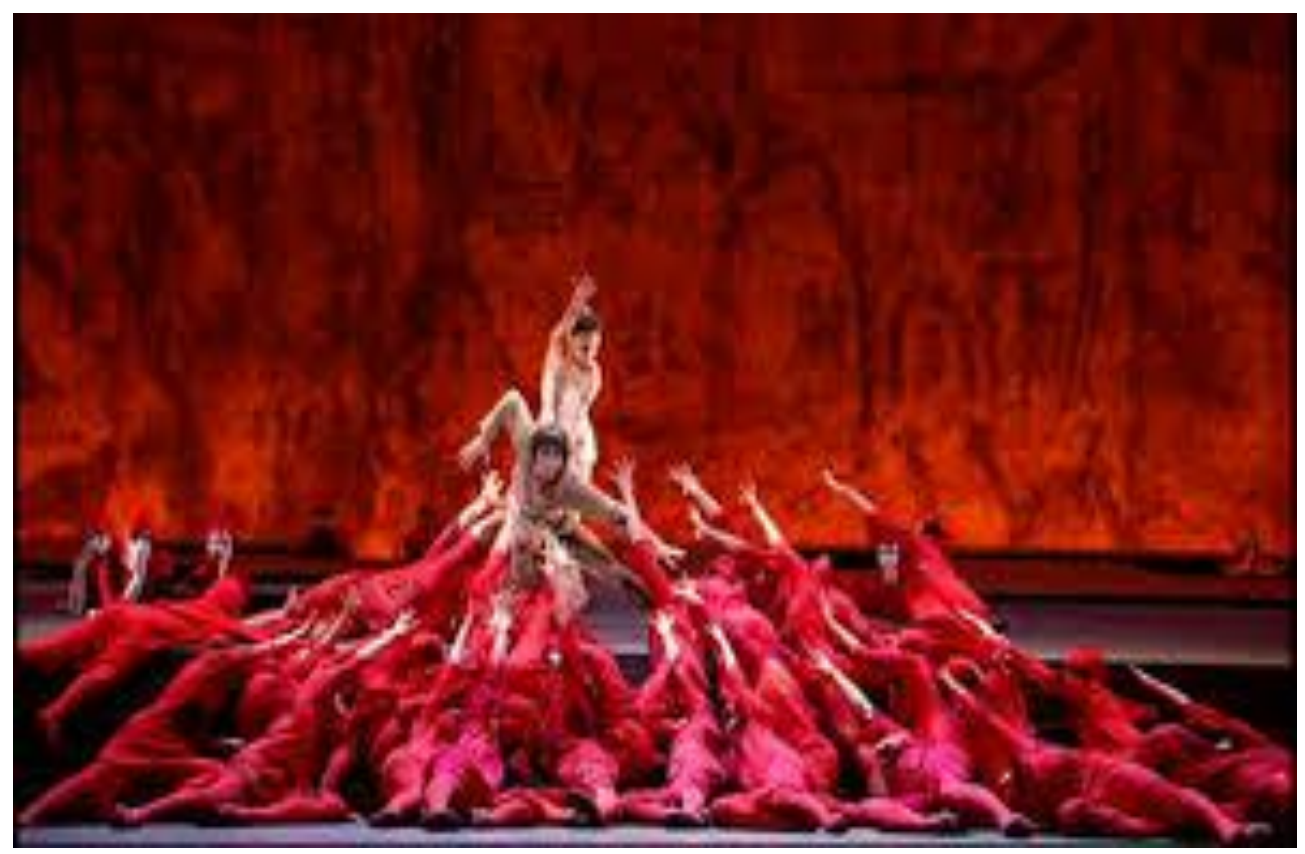

Figura 21 - La Cour de Miracles. 1996

Como cor fria, o iluminador escolhe variações de azul. As luzes nesse tom transmitem a sensação de delicadeza, passividade, ou ainda de solenidade e sobriedade. Na primeira sequência do quadro Cour de Miracles, em que Esmeralda é perseguida por Quasimodo na noite de Paris, a tela de fundo ganha essa nuance azulada, indicando não apenas o tempo da ação - durante a noite -, mas introduzindo o público nessa atmosfera sombria e misteriosa que se revelará na sequência com a aparição dos moradores da Cour de Miracles.

Esse mesmo tom de azul é usado em praticamente todo o segundo ato - exceto nos quadros Le clocher de Notre-Dame e Esmeralda e Quasimodo. Nos demais quadros ele ajuda a compor a carga dramática, dando as sequências um aspecto sombrio, como, por exemplo, no momento da execução de Esmeralda. 


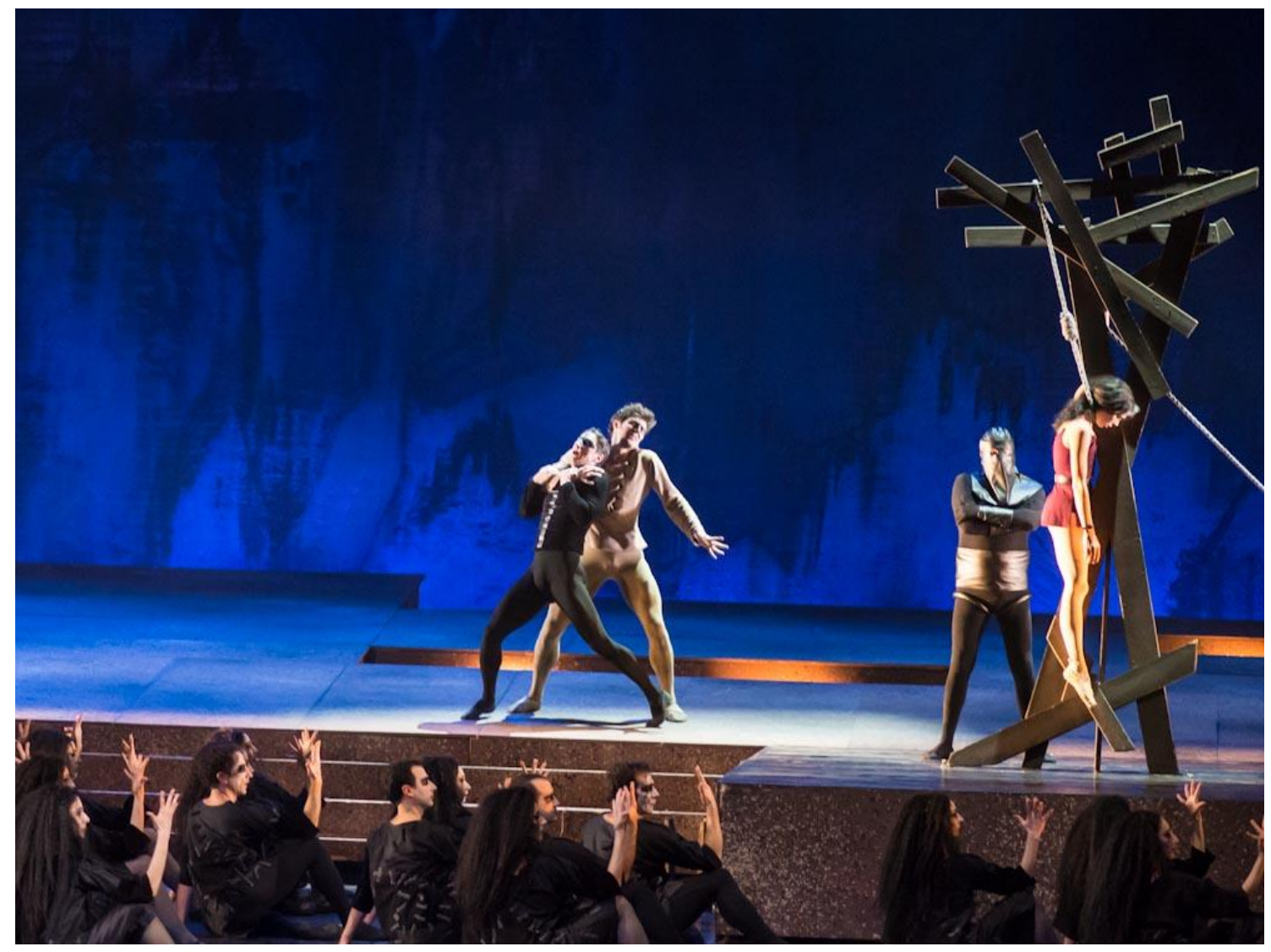

Figura 22 - La mort. 1996

Portanto, como se pode observar, apesar da especificidade de cada elemento que constitui um espetáculo de dança, da individualidade de cada profissional, bem como das possíveis escrituras tecidas por eles, todos os componentes devem estar em consonância a fim de escreverem uma narrativa coreográfica que possa ser decodificada pelo público. 


\section{CAPÍTULO IV}

\section{Coreo-GRAFIA: a construção da narrativa gestual}

Em nosso cotidiano, nossas relações com o outro se dão por meio de gestos. A articulação desses ocorre de maneira tão natural que quase nunca nos damos conta de sua importância, exceto no momento em que essa habilidade nos é retirada.

Apesar de singulares, os gestos são fundamentados em uma cultura grupal e adquirem sentidos diferentes de acordo com a época e com os grupos sociais que os executam. Assim, pode-se afirmar que, enquanto manifestação cultural, a gestualidade ganha significado, sendo passível de análises e interpretações.

É importante salientarmos que, ao falarmos de gestos, estamos automaticamente reivindicando sua dimensão expressiva e, consequentemente, realizando uma distinção entre um simples movimento e a gestualidade. Uma máquina, por exemplo, é capaz de realizar movimentos. Entretanto, ela não se exprime por gestos. De acordo com Glon e Launay,

Pode-se distinguir o movimento, entendido como um fenômeno referente aos estritos deslocamentos dos diferentes segmentos do corpo no espaço, do gesto, o qual se inscreve na diferença entre esse movimento e a tela de fundo tônica e afetiva do sujeito, ou seja, o pré-movimento em todas as sua dimensões afetivas e projetivas. É ai que reside a expressividade do gesto humano, o que nos diferencia das máquinas. ${ }^{111}$

Logo, ao privilegiarmos a noção de gesto ao invés de adotarmos o conceito de corpo em movimento, estamos acentuando o aspecto expressivo deste, dando ao movimento o que ele tem de humano e, consequentemente possibilitando o estudo das qualidades específicas de um gesto em um dado contexto.

De acordo com Trotta, os gestos podem ser divididos em duas categorias distintas: a práxis gestual e a comunicação gestual. "Na práxis gestual, a gestualidade aparece dessemantizada." 112 Ao ligarmos a televisão, por exemplo, realizamos uma série de movimentos intermediários entre o gesto inicial e o final, entretanto tais movimentos são desprovidos de significado, o que realmente importa nessa ação é alcançar o objetivo final, ou seja, ligar a televisão. Em outras palavras, pode-se dizer que os gestos intermediários entre um ato e outro realizado em nosso cotidiano não

\footnotetext{
${ }^{111}$ GLON; LAUNAY; 2012.p.17 (tradução nossa)

112 TROTTA, 2010, p. 23.
} 
conservam sentido, apenas desempenham sua função, possuem uma finalidade prática. No entanto, existe outro tipo de gestualidade em que ocorre a dissipação da finalidade prática e uma valorização, voluntária, de criar sensações e de ressemantizar significados. É dessa gestualidade que nasce a dança.

Ao criar uma narrativa coreográfica, o coreógrafo se apropria da práxis gestual e a ressemantiza, estabelecendo uma "utilidade de segunda ordem"113 para o movimento. Tanto ele quanto o bailarino dotam os gestos simples do dia a dia como andar, saltar, sentar-se entre outros de valor estético e, consequentemente transformam o gesticular em dançar. Esse ato de transformação não somente dá autonomia à movimentação como concede à gestualidade um caráter comunicativo, possibilitando o entendimento da dança como uma forma de linguagem.

Como postulado anteriormente, para que a dança seja entendida como um ato comunicativo devemos considerá-la como um texto sincrético, em que diversos componentes agregam materialidade e conteúdo para a elaboração de um todo de sentido. Assim sendo, ao estudarmos seu processo de construção, faz-se necessário a análise de cada elemento actante, bem como a escritura concebida por cada profissional envolvido.

No capítulo III, observamos como a música de Maurice Jarre, o figurino de Yves Saint Laurent, o cenário de Réne Allio e a iluminação de Jean-Michel Désiré atuam na composição da narrativa coreográfica de Notre-Dame de Paris. Cabe-nos, portanto, entender de que forma a gestualidade, enquanto escritura, colabora para o contrato de comunicação estabelecido entre o coreógrafo e o público. Assim, neste capítulo, buscaremos abordar os diversos elementos envolvidos em tal processo, a saber: a concepção da obra por Roland Petit; a elaboração do argumento do balé; a escolha dos personagens, bem como dos principais bailarinos; a construção da narrativa através dos movimentos e, por fim, como o amor e a monstruosidade são representados pela dança.

\subsection{Roland Petit: entre a dança e a literatura}

Segundo Roland Petit, sua paixão pela dança manifestou-se desde muito cedo. Aos nove anos de idade, ele pede para seu pai que o leve para uma audição na renomada Ópera de Paris. Após processo seletivo, Roland consegue ingressar na Escola de balé dessa instituição, onde seguiu sua formação como bailarino sob a orientação de Gustave

${ }^{113}$ TROTTA, 2010, p. 25 
Ricaux e Serge Lifar. Nesse mesmo período, ele conhece Zizi Jeanmarie, sua futura esposa e estrela de sua companhia.

Aos vinte anos, Roland Petit consegue seus primeiros papéis no corpo de baile do balé da Ópera de Paris. Apesar de serem pequenos, eles permitem que Petit adquira experiência e entre em contato com diversas personalidades influentes da época. Extremamente criativo e audacioso, Petit decide deixar a Ópera de Paris após o fim da Segunda Guerra Mundial e fundar sua própria companhia juntamente com Zizi. Por alguns anos, Petit viaja por diversos países com suas coreografias de sucesso, fazendo inclusive participações em filmes americanos e franceses, assim como em musicais.

Em 1965, a convite da diretoria, retorna à Ópera de Paris com o balé Notre-dame de Paris, no qual além de coreógrafo e libretista, era também bailarino, interpretando o papel de Quasimodo. Sucesso de público e de crítica, esse balé torna-se um dos clássicos mais reapresentados pela Ópera de Paris em todo o mundo e alça definitivamente Roland Petit ao estrelato, tornando-o um patrimônio da dança francesa e mundial.

A escolha de estrear como coreógrafo na Ópera de Paris, com um balé narrativo adaptado de uma obra literária não é feita por acaso. É interessante notar o gosto de Roland Petit pela literatura. Para o coreógrafo, a literatura é um alimento para dança. "A literatura revela a dança. O tema da dança não é ela mesma, é necessária uma matéria, caso o contrário, não é possível arrancar suspiros do público durante todo um espetáculo." 114 De fato, a dança clássica necessita de libretos conhecidos do grande público, para garantir a aproximação do espetador, que se distancia da gestualidade devido ao virtuosismo. Quando a dança parte de um libreto já conhecido pelo público, ela ganha espaço para explorar novos sentidos. Uma vez que a narrativa já está assegurada, o novo discurso pode se concentrar em sentimentos e antagonismos, sem prejuízo da narrativa.

Assim, no início de sua carreira, Roland Petit não apenas realiza releituras de grandes clássicos da dança como A Bela Adormecida, Coppelia e O Quebra nozes, como encomenda obras originais a grandes escritores de sua época para servirem de argumento para as suas coreografias. Entre os autores célebres que escrevem para Roland Petit estão Jean Cocteau, Jacques Prévert e Boris Kochno. Em um segundo momento, Petit decide adaptar para a dança clássicos da literatura dos séculos XIX e

\footnotetext{
${ }^{114}$ MANNON, 1984, p.99 (tradução nossa)
} 
XX como: L'Arlésienne, de Alphonse Daudet; Nana, de Zola, O Fantasma da Ópera, de Gaston Leroux; Em busca do tempo perdido, de Proust; A Dama de Espadas de Alexandre Pushkin, $O$ morro dos ventos uivantes, de Emily Brontë e $O$ Leopardo, de Lampedusa. Além de claro, Notre-Dame de Paris de Victor Hugo.

A grande quantidade de balés inspirados em obras literárias reflete, evidentemente, a estrita ligação deste coreógrafo com a literatura, mas, sobretudo, o seu gosto por contar estórias. Muito diferente da maioria dos coreógrafos de seu tempo, os quais criavam espetáculos sem personagens e histórias bem definidas, Roland Petit concebe balés com histórias narrativas de fácil compreensão e com personagens concretos, o que lhe rende o título de narrador coreográfico.

Assim, ao privilegiar a literatura para compor seus espetáculos, Roland Petit não apenas traz para a dança célebres personagens das narrativas literárias; como cria, dentro de seu domínio, grandes mitos; com vidas próprias, os quais passam, por sua vez, a fazer parte do imaginário popular.

\subsubsection{O processo de adaptação}

Segundo Roland Petit, grande parte dos temas de seus espetáculos surge de maneira espontânea. Com Notre-Dame de Paris esse processo não foi diferente. De acordo com relatos do próprio coreógrafo, há algum tempo, ele desejava escrever um balé que tivesse como cenário a Idade Média. Incialmente ele havia pensado em adaptar o romance de Matthew Gregory Lewis, The Monk, o qual narrava a história de um padre perverso. Porém, ao passar em frente a uma livraria em Paris, sua inspiração finalmente ganha forma.

\footnotetext{
Fascinado pela Idade Média e seu misticismo, comecei uma reflexão sobre $O$ monge de Lewis. Cheguei, até mesmo, a escrever um livreto e a encomendar uma partitura. Mas acabou não dando certo. Um dia, passando em frente a uma livraria, eu vi uma edição de Notre-Dame de Paris. Como sempre, cismado com a Idade Média e seus monges, decidi comprar a obra cujos detalhes eu havia esquecido. Relendo o romance, constatei que Victor Hugo ia muito além que Lewis. Imediatamente, reescrevi meu livreto, dessa vez seguindo Hugo. ${ }^{115}$
}

A ideia de escrever um espetáculo baseado em um personagem diabólico agradava Roland Petit. Logo, assim como Victor Hugo, o coreógrafo elegeu Claude Frollo como

\footnotetext{
${ }^{115}$ FIETTE, 2007. p. 24 (tradução nossa)
} 
o fio condutor de sua narrativa, escrevendo seu livreto e montando a coreografia a partir da monstruosidade moral do personagem.

\subsubsection{Notre-Dame de Paris: uma história de amor e de morte}

Ao analisarmos o argumento do balé elaborado por Roland Petit, podemos notar uma série de diferenças em relação à obra de Victor Hugo. No balé, Petit executa um trabalho de transposição da obra hugoana para os códigos da dança, delimitando o enredo - repleto de tramas e personagens secundários no romance-, assim como restringe o seu conteúdo intelectual.

Tais modificações ocorrem, primeiramente, devido às necessidades inerentes à transformação de um código para outro, como, por exemplo, a questão do tempo. No balé, Roland Petit dispõe de aproximadamente $1 \mathrm{~h} 20$ para recriar um texto de mais de 700 páginas. Essa quantidade limitada de tempo em relação à obra monumental de Victor Hugo implica em uma série de escolhas e reduções no que diz respeito aos temas e aos personagens. Ademais, por se tratar de um espetáculo de dança, o qual deve seguir certa linearidade de forma a ser compreensível para o público, não é possível retratar todas as digressões e pensamentos expostos no romance hugoano. Entretanto, é importante ressaltar que essas simplificações e escolhas não tornam a narrativa coreográfica inferior ao livro. Trata-se de uma recriação, um objeto estético com vida própria.

No romance Notre-Dame de Paris, o leitor é conduzido por uma narrativa nãolinear, com digressões do narrador a respeito de variados temas, tais quais a fatalidade, a história da arquitetura, a política, as relações sociais a importância da catedral de Notre-Dame, a monstruosidade, o combate à pena de morte, entre outros. Essas reflexões têm como pano de fundo a trágica história da jovem cigana Esmeralda, vítima do afeto que desperta em quatro homens: Quasimodo, Frollo, Phœbus, Gringoire. Assim em meio a um complexo enredo, Victor Hugo recria na ficção a sociedade da Paris medieval e revela as diferenças dos seus atores sociais.

Partindo de Hugo, Roland Petit reduz o espectro de personagens e se concentra na trama afetiva, a qual exclui Pierre Gringoire e Fleur-de-Lys. Outros personagens como La Chantefleurie - respetivamente marido e mãe de Esmeralda -,Clopin Trouillefou, o rei Luís XI e a cabra Djali são omitidos do balé. A decisão de não retratálos na narrativa coreográfica não ocorreu pelo fato de eles serem mais ou menos importantes no romance. Tal escolha deu-se, primeiramente, por uma questão de 
limitação da quantidade de personagens que pode haver em um balé, o qual não permite uma trama complexa com personagens principais e secundários. Ademais, essa opção por uma trama mais sóbria dar-se-á devido a escolha de Roland Petit de trabalhar apenas com o que ele afirmar ser essencial no romance: o viés trágico da história.

De acordo com Roland Petit, seu principal objetivo ao adaptar Notre-Dame de Paris era contar, através da dança, uma história de amor e de morte, que fosse atemporal e universal.

\begin{abstract}
Meu balé Notre-Dame de Paris conta uma bela e grande história. Deliberadamente, eu o afastei da pantomina e da anedota: eu quis estampar a Idade Média de Viollet-le-Duc afim de que, no final, restasse para o espectador o trágico da obra de Victor Hugo. Enquanto libretista e coreógrafo, eu vejo os três personagens dessa paixão fatal como seres 'a parte': Esmeralda - como o amor - é uma criança cigana suspeita de realizar bruxaria. Quasimodo não é um monstro, ele está mais para um sujeito complexado, pois ele sofreu um acidente. Um ser rejeitado por sua diferença. Quanto a Frollo, temos um homem dividido entre seus desejos e sua consciência, entre a carne e o espírito. Essa poderia ser uma história de nossos dias. ${ }^{116}$
\end{abstract}

Pode-se observar que a intriga, apesar de inspirada no romance - com exceção do final, em que Frollo mata Phœbus com um golpe de punhal -, baseia-se principalmente nos sentimentos particulares que ligam Esmeralda aos outros personagens. Construída sob o signo da fatalidade, a trama de Roland Petit se desenvolve a partir da relação estabelecida entre o quarteto principal, bem como a partir das dualidades por eles confrontadas. Apesar de não ser retratado de forma explícita, o princípio dos contrários, postulado no Prefácio de Cromwell por Victor Hugo aparece na obra de Roland Petit sob a forma de valores opostos com os quais os personagens se confrontam, tais quais: a feiura e a beleza, a devoção e o desejo, o amor e a morte, etc.

Além do quarteto amoroso, os demais personagens retratados no balé são personagens coletivos cuja representação é feita pelo corpo de baile. Entre eles podemos distinguir: a aristocracia, o povo, os habitantes diabólicos do pátio dos milagres, os soldados e as prostitutas do cabaré frequentado por Phœbus. Seria, então, possível pensar que Roland Petit articula sua narrativa não só em torno do quarteto amoroso, mas também em torno do povo em suas diversas representações.

É possível observar esse eixo pelo qual se desenvolve a narrativa coreográfica desde a primeira cena do balé. Primeiramente surge a nobreza, a qual desfila pelo palco

${ }^{116}$ FIETTE, 2007, p. 24 
com suas roupas de época, cedendo lugar à multidão colorida da Festa dos Loucos. Em seguida, um a um, os personagens principais vão se apresentando ao público. Primeiramente surge Quasimodo, eleito "papa dos loucos" pela sua feiura. Posteriormente, Frollo, o arquidiácono de Notre-Dame, o qual lembra ao povo de que a vida não é feita somente de prazeres e que é preciso rezar e se arrepender. Depois, observa-se a entrada em cena da sedutora Esmeralda. A partir daí, a narrativa se desenrola, até que, no sexto quadro do primeiro ato, surge Phœbus desfilando com os seus soldados.

Assim, ao optar por transpor Notre-Dame de Paris ressaltando o seu lado trágico, Roland Petit abandona, de certa forma, um pouco da prolixidade hugoana sem, no entanto, perder a essência da narrativa romanesca. Apesar de mais simples, a narrativa coreográfica consegue traduzir, por meio da dança, as grandes linhas do romance de Victor Hugo.

\subsection{A escolha dos intérpretes}

Tendo definido o programa e os artistas responsáveis por cada elemento que constitui o balé, coube a Roland Petit escolher entre os astros que compunham o elenco da Ópera de Paris, os bailarinos que interpretariam os quatro principais personagens. Para Petit, essa tarefa era tão importante quanto à elaboração do espetáculo em si, pois, segundo ele " o balé não é quadro que, uma vez acabado, não se toca mais. A interpretação é essencial." ${ }^{, 117}$ Ademais, ele tinha a consciência que a escolha de certo bailarino, muitas das vezes, determinava o triunfo ou o fracasso de um espetáculo. Como Notre-Dame de Paris foi um sucesso não só entre a crítica, mas também com o público, ele vem sendo reapresentado há mais de cinco décadas em diversos países. Tal longevidade implicou em sucessivas mudanças de elencos e, consequentemente, variadas interpretações de cada personagem.

Em 1965, ano de estreia do balé, o próprio Roland Petit estrelou no papel de Quasimodo, escolhendo para si o papel de maior destaque. Aos 41 anos, ele trouxe para a cena um Quasimodo fisicamente disforme, porém humano, capaz de emocionar o público com a sua doçura. Nas temporadas seguintes, outras grandes estrelas da Ópera de Paris, como Cyril Atanassoff et Jean Guizerix, dedicaram-se a tal personagem. É interessante notar que o papel de Quasimodo foi interpretado, durante muitos anos, por bailarinos mais velhos, geralmente, dançarinos consagrados da Opéra de Paris.

\footnotetext{
${ }^{117}$ Roland Petit, Rythme de vie. Entretiens avec Jean-Pierre Pastori . p. 100 (tradução nossa)
} 
Esse estereótipo muda somente na década de noventa, quando Nicholas Le Riche - o Quasimodo da versão em análise - assume o personagem. Com cerca de 20 anos de idade, Nicholas Le Riche resgata a jovialidade de Quasimodo, deixando-o praticamente com a mesma idade do personagem hugoano. A interpretação e a leveza dos movimentos executados por esse bailarino imprimem ao monstruoso sineiro da narrativa coreográfica uma delicadeza, a qual ressalta, desde o início do balé, a ambiguidade de Quasimodo.

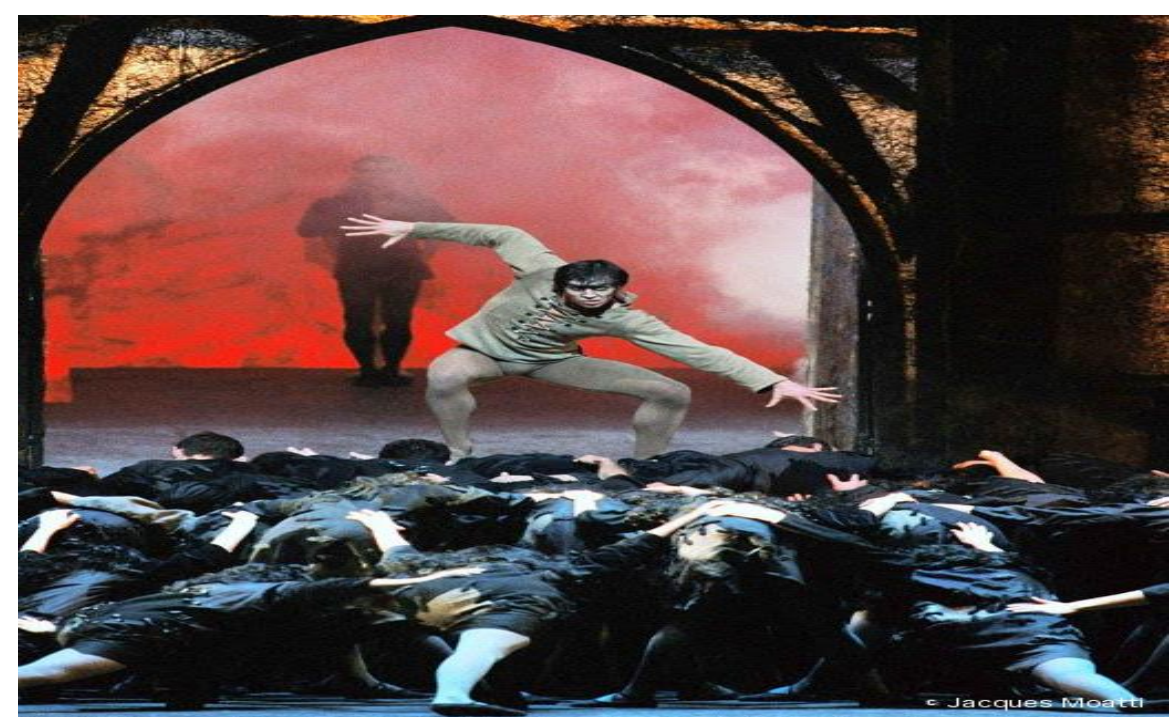

Figura 23 - Nicolas Le Riche como Quasimodo, em Notre-Dame de Paris. 1996

Já o papel de Esmeralda é interpretado inicialmente por Claire Motte. Nos anos seguintes, outras estrelas da Ópera de Paris como Elisabeth Platel, Sylvie Guillem, e Isabelle Guérin -a Esmeralda da versão em análise - revezaram-se no posto. Além das qualidades técnicas exigidas rotineiramente para a escolha de uma bailarina principal, foi necessário levar em consideração o talento teatral das dançarinas, uma vez que a "Esmeralda" da narrativa coreográfica carrega uma grande carga dramática. Como postulado anteriormente, a Esmeralda de Roland Petit difere-se bastante da personagem hugoana, ao apresentar-se como uma mulher mais audaciosa, em oposição à menina passiva da narrativa textual. De fato, a bailarina escolhida para tal papel deveria ser capaz de representar a evolução da personagem ao longo dos dois atos do espetáculo. Era necessário que o público notasse a transformação da personagem, a qual passa de mulher livre e sedutora, porém inocente, a uma mulher aflita, considerada criminosa, entretanto corajosa, uma vez que ela mesma caminha até a forca, sem ser forçada por ninguém. Assim, o papel de Esmeralda exige da bailarina não somente uma técnica impecável como também um talento teatral, tendo em vista que essa personagem em 
nada lembra a imagem das bailarinas românticas, tradicionais da dança clássica. Aclamada por Noureev pela sua sensibilidade e talento para a interpretação, Isabelle Guérrin é reconhecida no meio da dança por imprimir sua personalidade e autenticidade nos personagens que desempenha. Como é possível perceber pelo vídeo analisado, com Esmeralda não foi diferente.

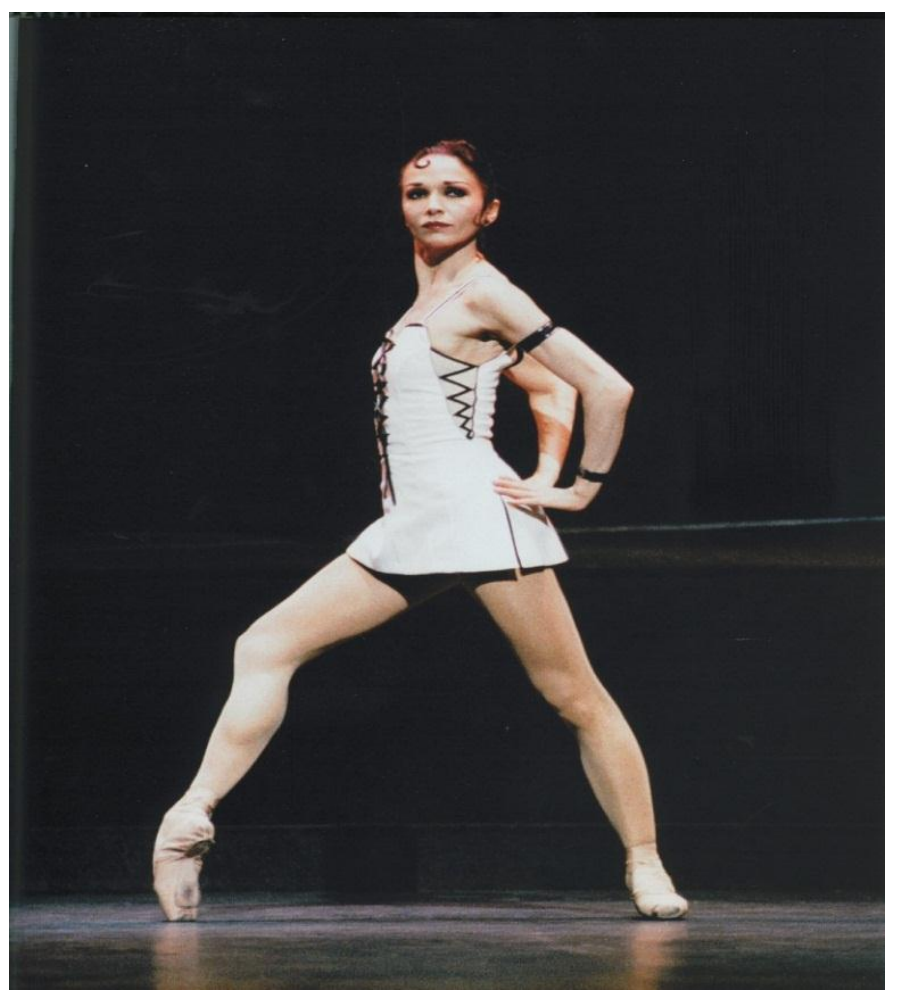

Figura 24 - Isabelle Guérin como Esmeralda, em Notre-Dame de Paris, 1996

Por sua vez, o papel de Frollo é interpretado por Cyril Attanasoff na temporada de estreia de Notre-Dame de Paris. Nos anos subsequentes, outros intérpretes revezaram-se no papel, até o momento em que Laurent Hilaire, o bailarino da versão em análise assume a função. Hilaire imprime no personagem de Claude Frollo uma frieza formidável, a qual ele expressa tanto pela sua gestualidade quanto pelo seu semblante sempre severo. Sua interpretação é de tal densidade e violência que suscita no público o terror vivido por Esmeralda. 


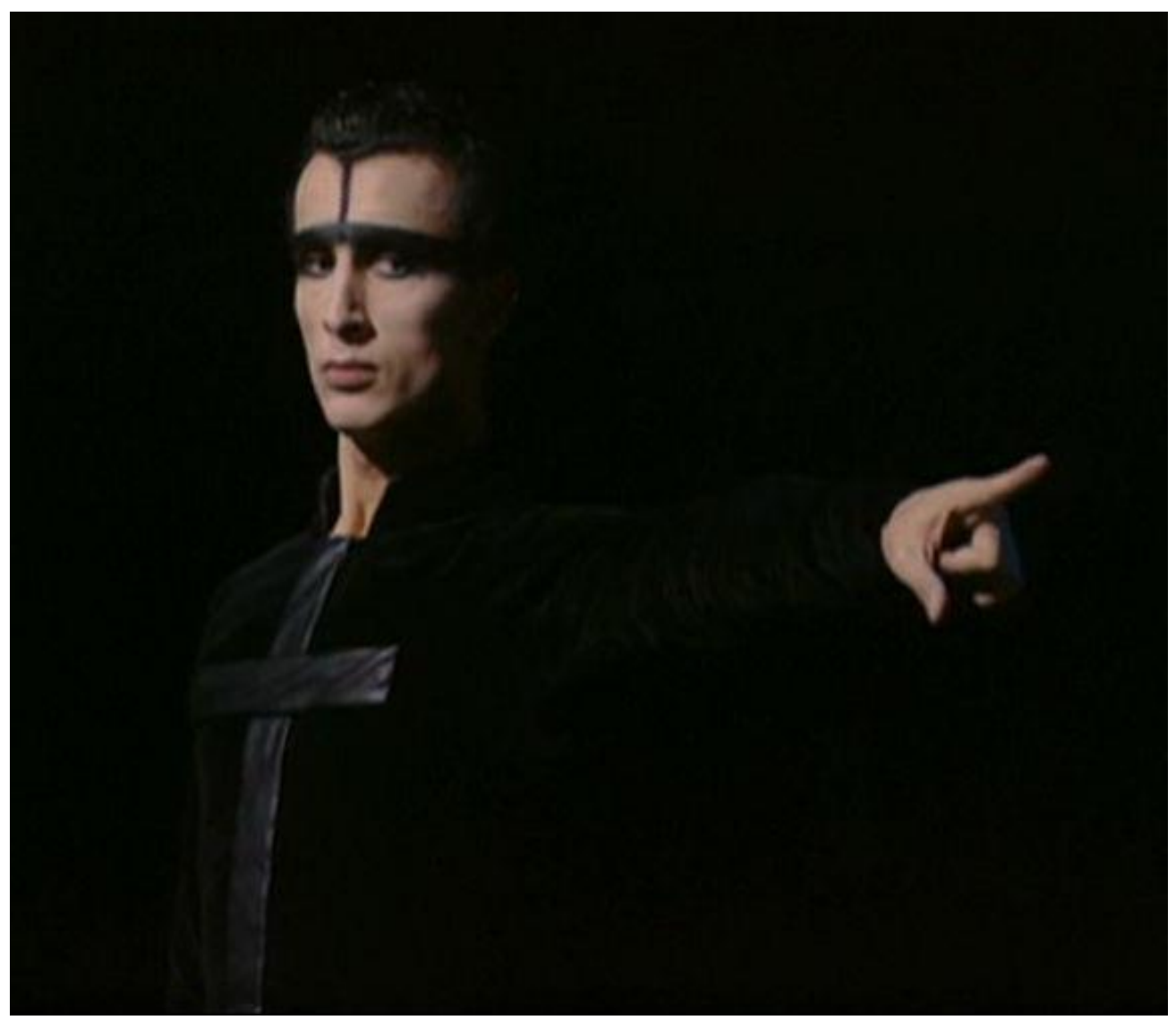

Figura 25 - Laurent Hilaire como Claude Frollo, em Notre-Dame de Paris, 1996

Já o papel de Phœbus é interpretado incialmente por Jean Pierre Bonnefous. Na versão em análise, podemos contemplar a atuação de Manuel Legris, o qual interpreta o personagem a partir da ideia do herói sedutor e conquistador da narrativa hugoana.

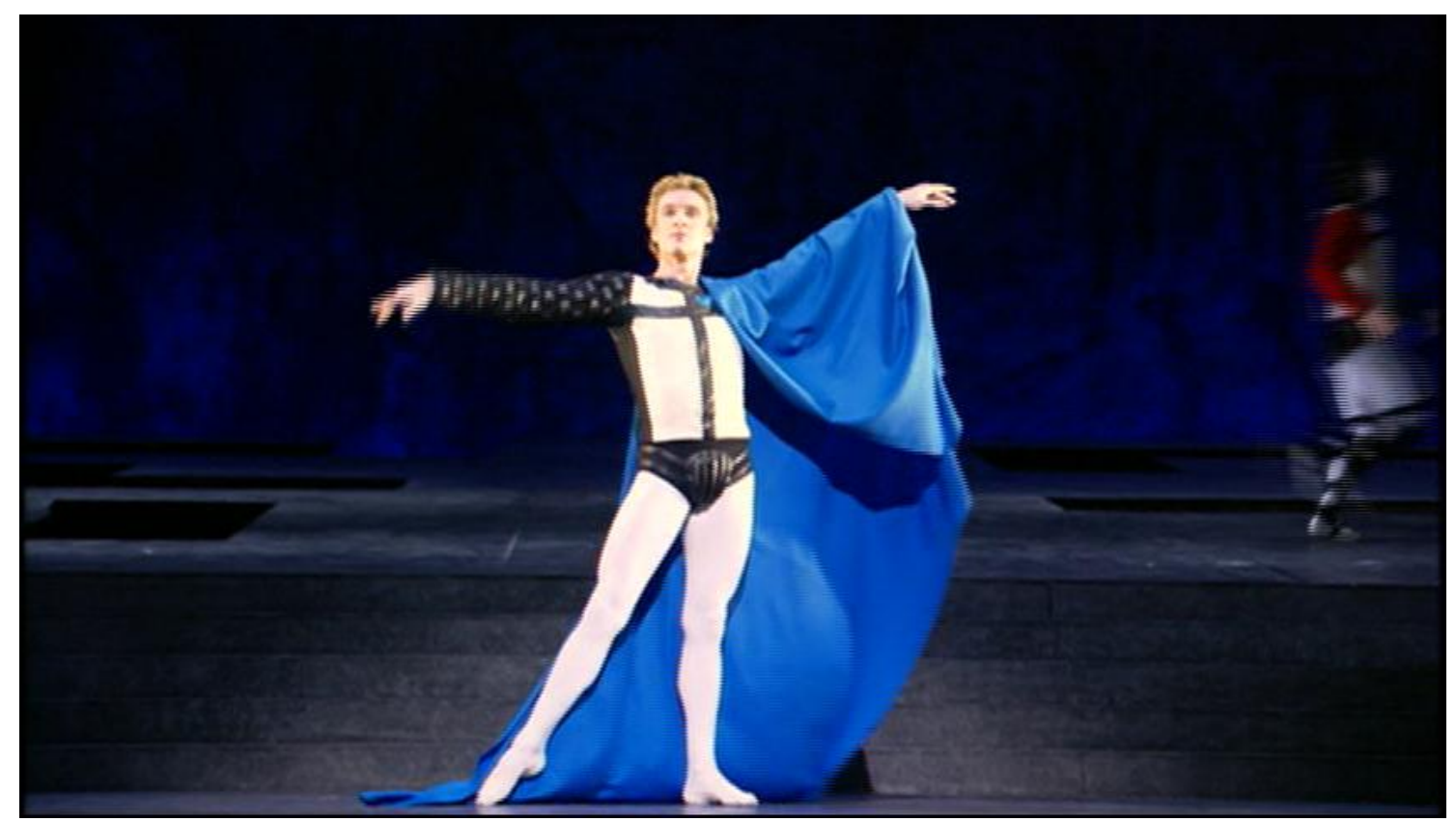

Figura 26 - Manuel Legris como Phœbus, em Notre-Dame de Paris, 1996 
A escolha dos bailarinos como Nicolas Le Riche, Laurent Hilaire e Manuel Legris para a representação da versão em análise imprime algumas características interessantes para os personagens da narrativa coreográfica. Podemos observar, por exemplo, que apesar de interpretar um homem sensual e conquistador, o bailarino intérprete de Phœbus possui uma feição delicada, quase feminina. Seus atributos físicos assim como sua interpretação criam um Phœbus de traços suaves. Essa característica é reforçada por sua dança que, em grande parte, é composta por movimentos ligados à estética clássica. A junção de todos esses elementos cria um efeito interessante. Embora Phœbus seja um herói galanteador, ou ainda, um príncipe encantado aos olhos de Esmeralda, ele um personagem delicado, vulnerável, o qual não cumpre com o papel de herói da narrativa. Ao contrário, esse personagem chega a ser irônico, o que nos parece até mesmo, uma crítica à dança clássica.

Tal constatação torna-se ainda mais evidente quando colocamos Phœbus em perspectiva com os outros dois personagens masculinos da narrativa. Tanto Quasimodo quanto Claude Frollo possui semblantes e características mais viris. A opção por representar esses os personagens dessa maneira pode ser atribuída, primeiramente, ao fato de ambos serem os dois grandes personagens masculinos da narrativa, sendo Frollo o perverso vilão e Quasimodo o grande herói. Apesar de suas deformidades físicas e de sua fealdade, Quasimodo é o verdadeiro herói da narrativa coreográfica, uma vez que é ele quem salva a vida de Esmeralda e a protege de seu carrasco Claude Frollo, o maldoso e sombrio padre de Notre-Dame.

Assim, ao selecionar bailarinos com físicos diferentes e interpretações mais ou menos viris, Roland Petit mantém a inversão de valores proposta por Victor Hugo. O herói de ambas as narrativas é um monstro, enquanto que o belo príncipe não passa de um galanteador que visa se aproveitar de Esmeralda.

\subsection{Da coreografia}

Em uma época em que a dança moderna vivia seu apogeu nos palcos dos grandes teatros, Roland Petit não deixava de demonstrar sua preferência pelo balé clássico. Para o coreógrafo, a dança clássica era a base de todas as outras danças, uma vez que o bailarino dominasse essa técnica, ele poderia dançar qualquer outro estilo.

Apesar de tal predileção, Petit não se prendia aos moldes rígidos do balé clássico, o qual segue regras estritamente definidas. Suas coreografias conservavam esse estilo como base, entretanto eram compostas por gestualidades pertencentes a outros 
estilos. De fato, as criações de Roland Petit eram verdadeiros laboratórios, em que diferentes linguagens eram testadas. "Eu acredito que a coreografia clássica que tem a oportunidade de utilizar todas as linguagens - tradicionais, contemporânea ou típica deve tentar ser em si mesma um laboratório, concebendo a linguagem mais apta a traduzir aquilo que se quer dizer." 118

Com Notre-Dame de Paris não foi diferente. Petit incorporou à dança clássica movimentos provenientes de outros estilos como: a posição en dedans ${ }^{119}$, movimentos angulares e em plie $^{120}$, batidas com os pés e com as mãos no palco, etc. A introdução desses movimentos produziu um estilo de coreografia, à qual os estudiosos em dança classificam como neoclássico. Esse tipo de dança incorpora linhas e elementos clássicos, porém pode divergir dessa estética ao incluir mãos e pés flexionados, contrações, ombros curvados, formações não convencionais de dançarinos e grupos de muitos bailarinos desempenhando coreografias diferentes ao mesmo tempo.

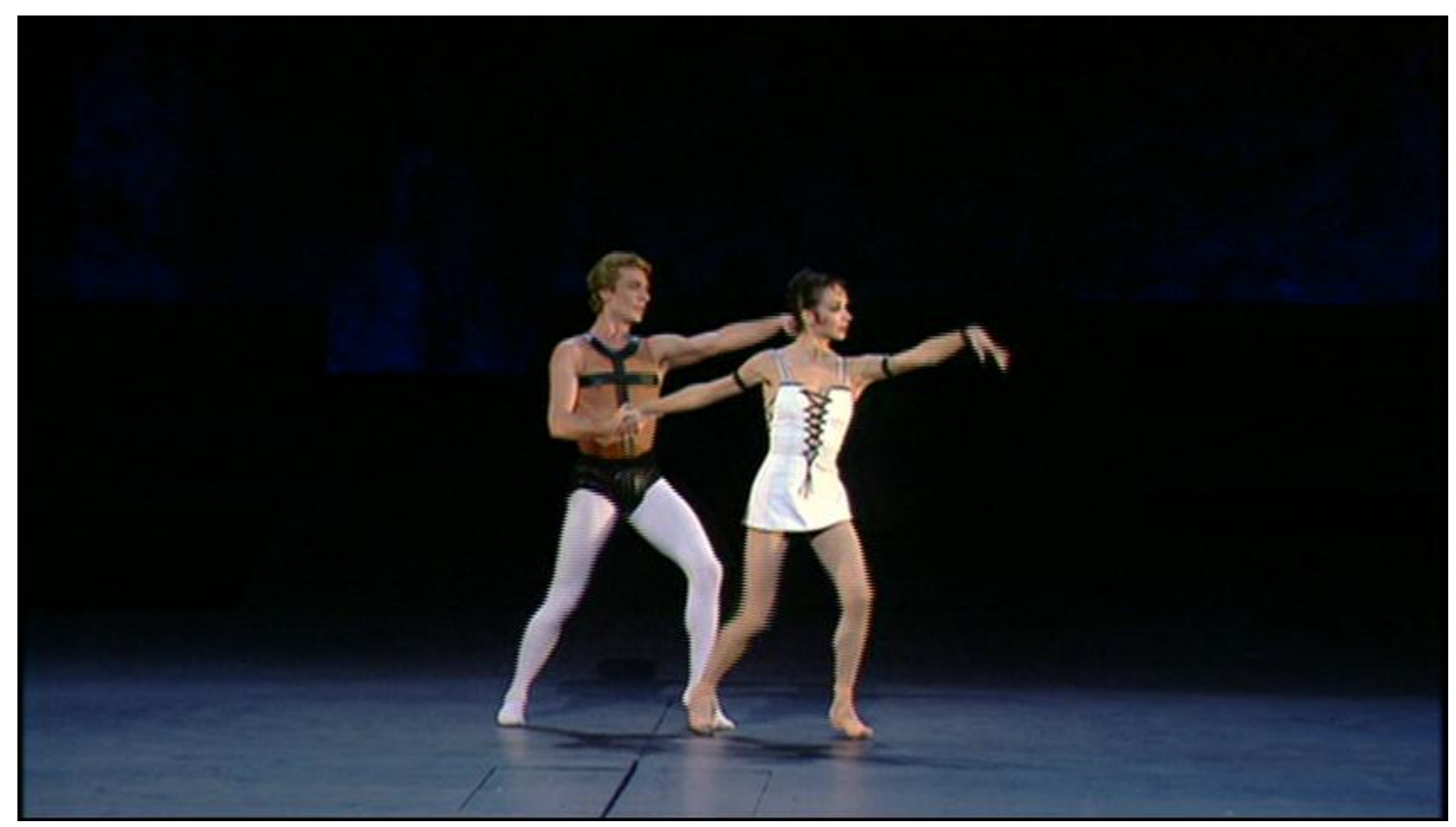

Figura 27 - Phoebus e Esmeralda, em Notre-Dame de Paris, 1996

\footnotetext{
118 MANNONI,1984. p.43 (tradução nossa)

${ }^{119}$ Para dentro. Indica que: (a) o movimento da perna é feito numa direção circular de trás para frente; (b) uma pirueta é executada girando para o lado da perna de sustentação.

${ }^{120}$ Dobrado. Flexão dos joelhos.
} 


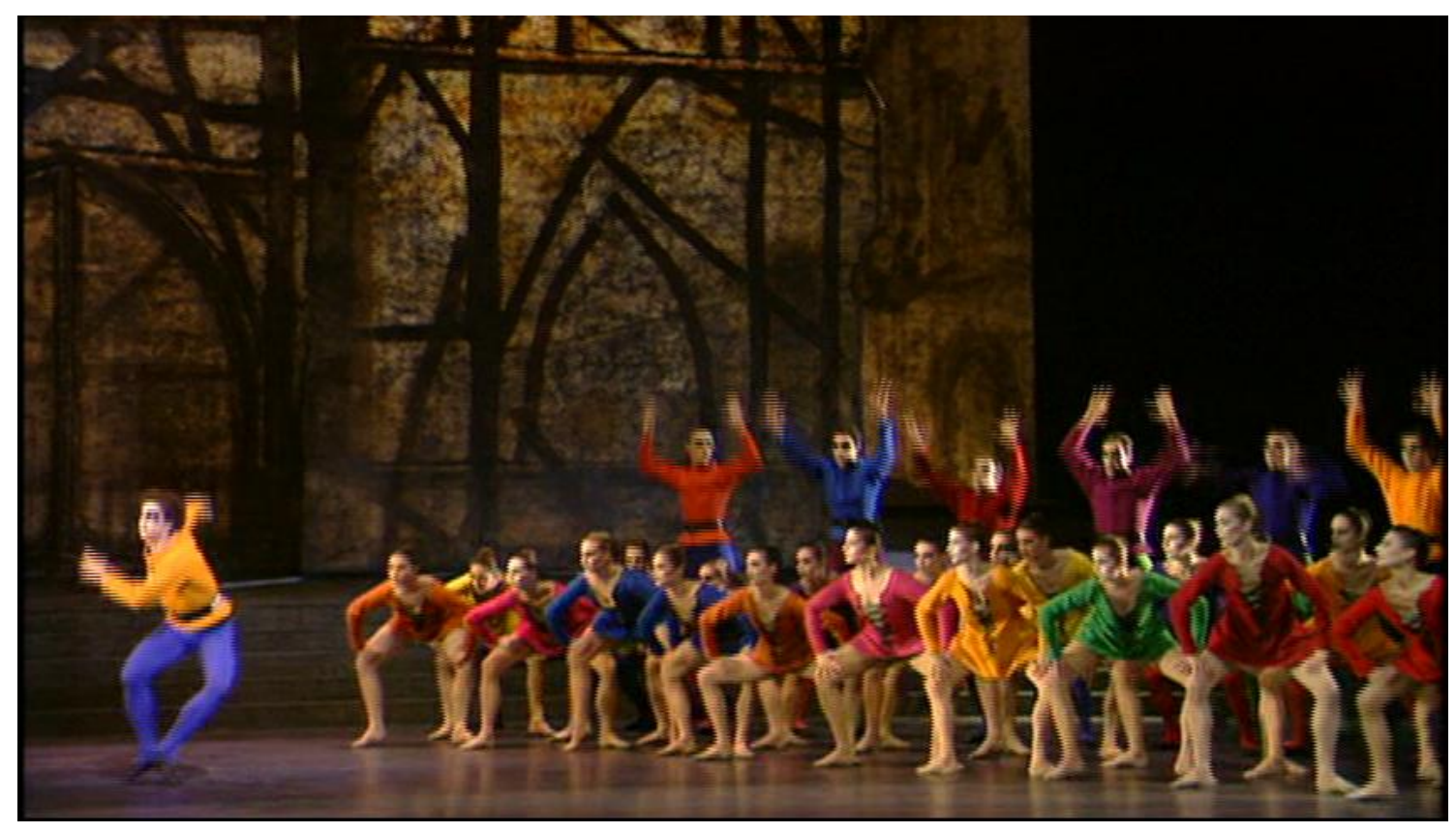

Figura 28 - A multidão em Notre-Dame de Paris, 1996

Além de movimentos de outros estilos, Roland Petit incorpora em seu balé gestos pertencentes ao nosso cotidiano. Essa prática pode ser notada, por exemplo, na sequência Festa dos loucos, quando Quasimodo sofre com os risos de escárnio emanados do corpo de baile. Os risos, apesar de integrarem a coreografia, parecem algo natural em cena e agregam ainda mais significado ao quadro.

Efetivamente, todos esses acréscimos à gramática rígida da dança clássica fazem de Notre-Dame de Paris uma obra singular. Ao se desvencilhar dos padrões préestabelecidos, Roland Petit cria uma coreografia capaz de expressar diferentes sentimentos, atribuindo significado à gestualidade, o que normalmente não ocorre em um balé clássico, onde os gestos em si não carregam sentido.

\subsubsection{A construção dos personagens pela gestualidade}

Para a escritura coreográfica dos personagens de Notre-Dame de Paris, Roland Petit buscou na narrativa hugoana elementos capazes de evocarem uma gestualidade única para cada personagem. A partir das figuras estilísticas de Victor Hugo, ele concebe uma coreografia capaz de não apenas recontar a narrativa hugoana, mas também de criar novas metáforas e imagens que passam a fazer parte do imaginário do universo da dança. Assim, no balé, cada personagem é caracterizado por uma gama de 
gestos específica, a qual identifica tanto o personagem como a sua relação com os demais.

Começaremos nossa análise por Quasimodo. Sabemos que no romance hugoano, Quasimodo é caracterizado como um ser bestial devido as suas deformidades físicas. Victor utiliza-se de uma série de adjetivos a fim de dar ao leitor uma imagem desse ser monstruoso. De acordo com o autor, Quasimodo possuía um nariz tetraedro, uma boca recurva como uma ferradura; um pequenino olho esquerdo obstruído por uma sobrancelha ruiva e áspera como tojo, um o olho direito que desaparecia completamente sob uma enorme verruga, uma dentadura desordenada, aqui e além brechada e um lábio caloso, por sobre o qual avançava um desses dentes como uma presa de elefante. Ele era alto e grande, seus pés eram largos e entre seus ombros ele carregava uma corcunda. Apesar de ser descrito como um ser ágil, vigoroso e musculoso, Quasimodo era manco.

Em virtude dessas deformidades físicas, Quasimodo é designado em diferentes trechos do romance como uma besta - até mesmo como o próprio diabo -, um ciclope, uma mistura de homem e animal, um caso teratológico. Suas deformidades físicas eram tantas que, de acordo com Barreto (2006), Victor Hugo convida o leitor, o qual provavelmente teria dificuldades de esboçar em seu imaginário tal figura, a sonhar, caso ele possa, com esse conjunto.

Logo, se mesmo o leitor poderia apresentar dificuldades em apreender a figura monstruosa de Quasimodo, apesar da grande quantidade de metáforas e adjetivos; cabenos questionarmos, de que forma Roland Petit recria gestualmente tal monstruosidade, de modo que o espectador compreenda as deficiências e a feiura associadas ao personagem.

Em um primeiro momento, a solução mais óbvia parece-nos a caracterização do personagem através de figurinos e maquiagens, no entanto Roland Petit abre mão desse recurso. Nenhuma das deformidades de Quasimodo é retratada dessa forma, tudo é recriado através da dança. Sua deformidade surge por meio da postura e dos gestos do bailarino. A corcunda, por exemplo, é representada pelo bailarino que durante praticamente todo o balé tem o seu braço esquerdo dobrado e erguido em relação à sua cabeça, criando por sua postura tal má-formação física. 


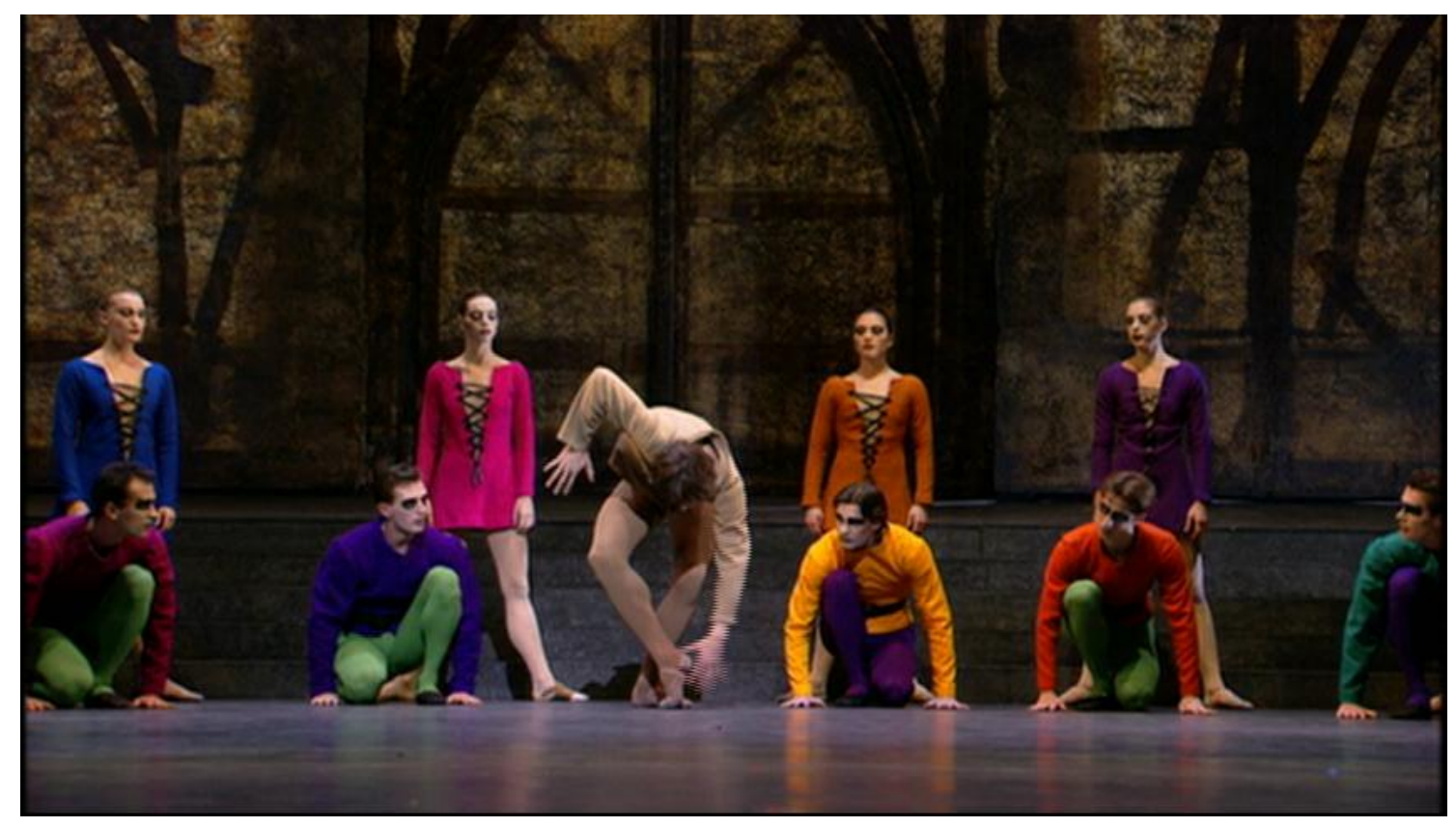

Figura 29 - Nicolas Le Riche como Quasimodo, em Notre-Dame de Paris, 1996

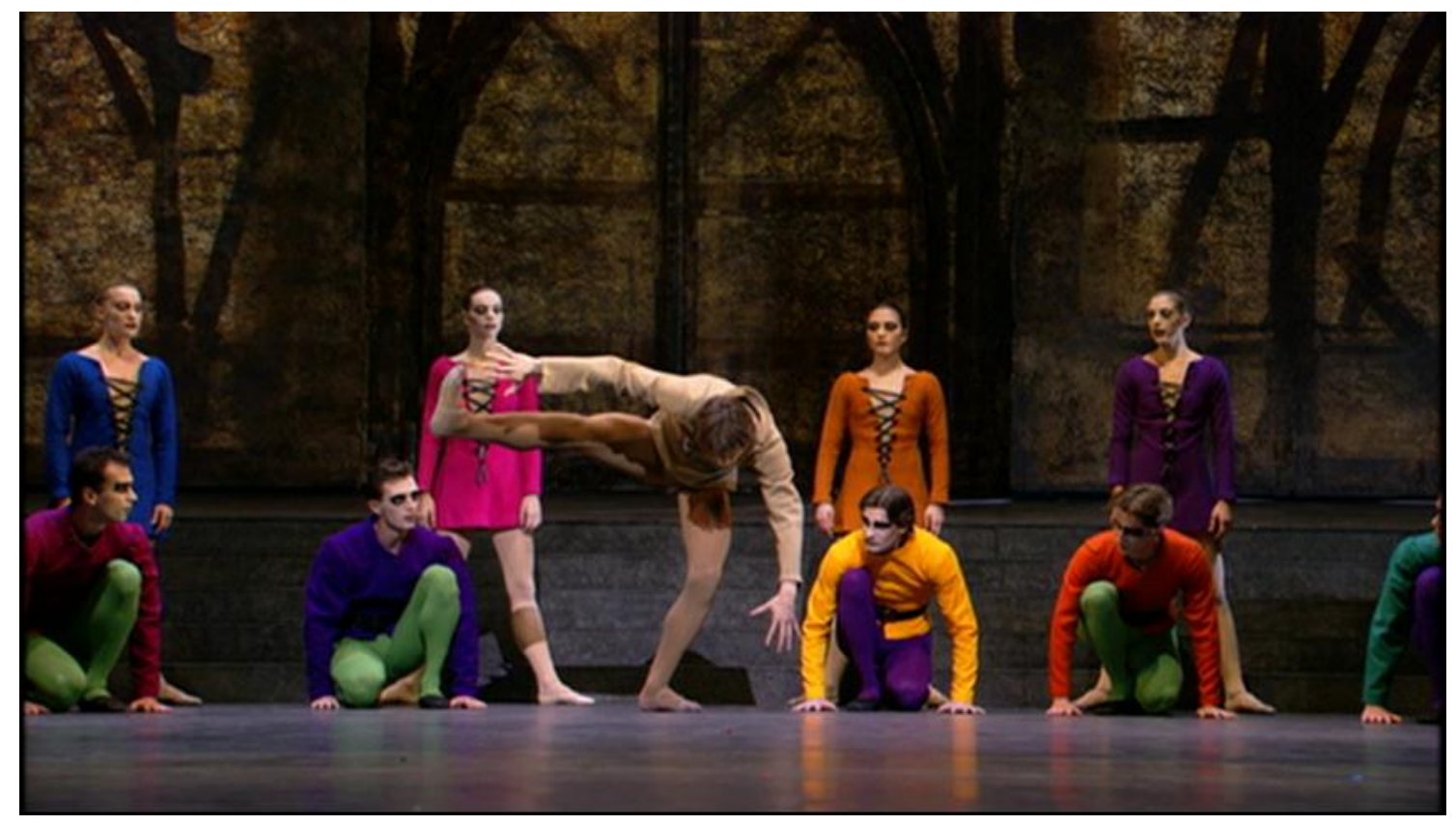

Figura 30 - Nicolas Le Riche como Quasimodo, em Notre-Dame de Paris, 1996 


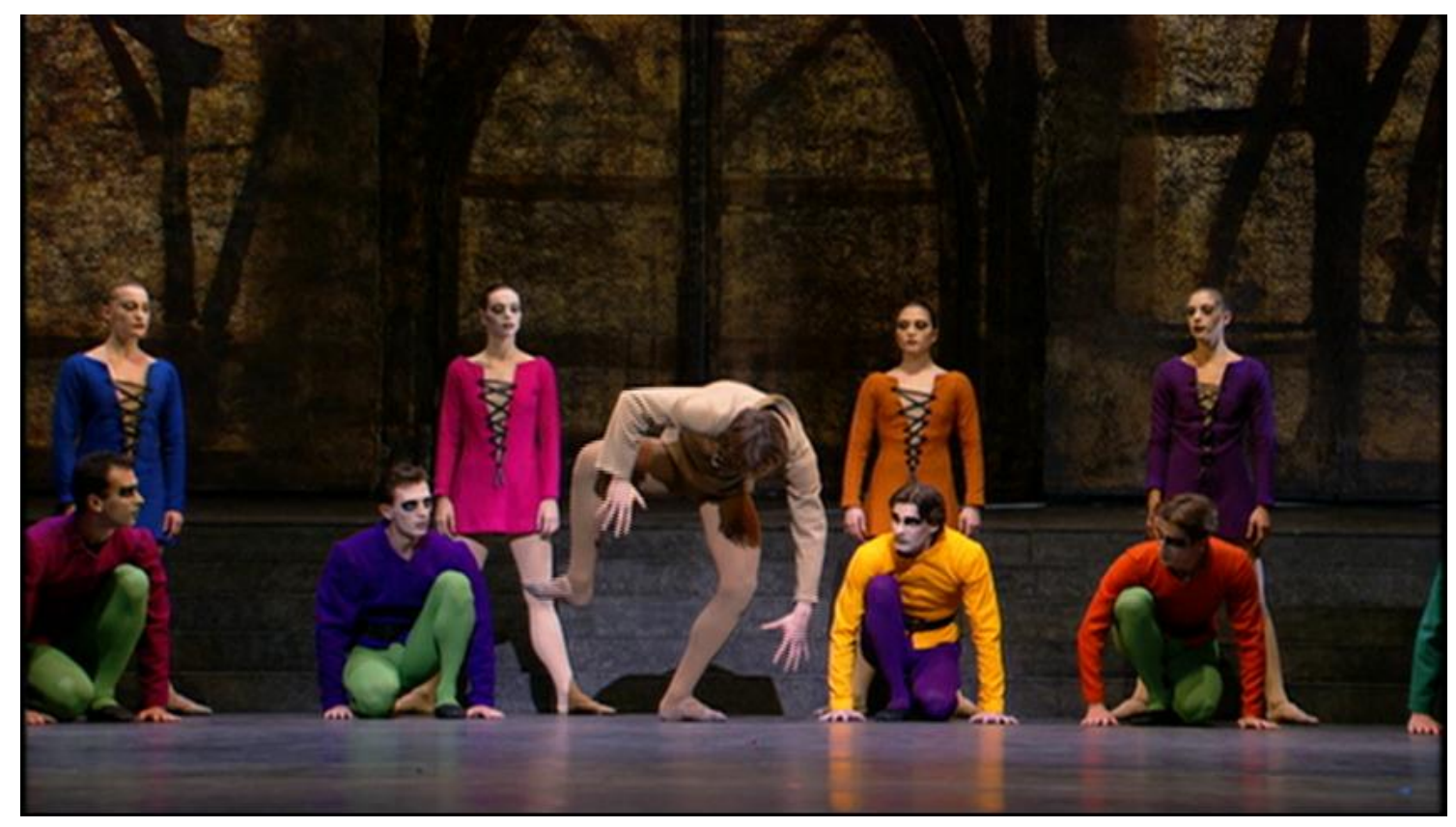

Figura 31 - Nicolas Le Riche como Quasimodo, em Notre-Dame de Paris, 1996

Apesar das demais características físicas elencadas por Victor Hugo não serem exibidas, as metáforas e os adjetivos usados pelo autor para elaborar essa descrição parecem ter influenciado Roland Petit na composição da gestualidade de Quasimodo. No romance, é possível observar o uso de metáforas que aludem a formas geométricas ao descrever a figura monstruosa desse personagem, tais como: um nariz tetraédrico, uma boca recurva como uma ferradura, as pernas que pareciam duas foices cruzadas quadradas na base, etc. Essas formas angulares também são adotadas na escrita coreográfica de Petit. Durante grande parte do balé, Quasimodo realiza movimentos de forma angular e quebrada, o que proporciona a "quebra de linha" vertical tradicional do balé clássico e consequentemente valoriza o plano médio do palco.

Todavia, esses movimentos em baixo plano se contrastam com alguns poucos movimentos que aludem à dança clássica. Esses gestos executados em um plano mais elevado, parece-nos uma tentativa de representação do desejo de libertação do corpo que enclausura o personagem, pois, assim como no romance, o Quasimodo da narrativa coreográfica, na verdade, é um ser sensível e generoso, escravo de um corpo defeituoso. O empreendimento de realizar movimentos em plano superior quase nunca é bem sucedido, uma vez que o personagem sempre retorna a sua posição inicial, a qual remete a sua má-formação física. 


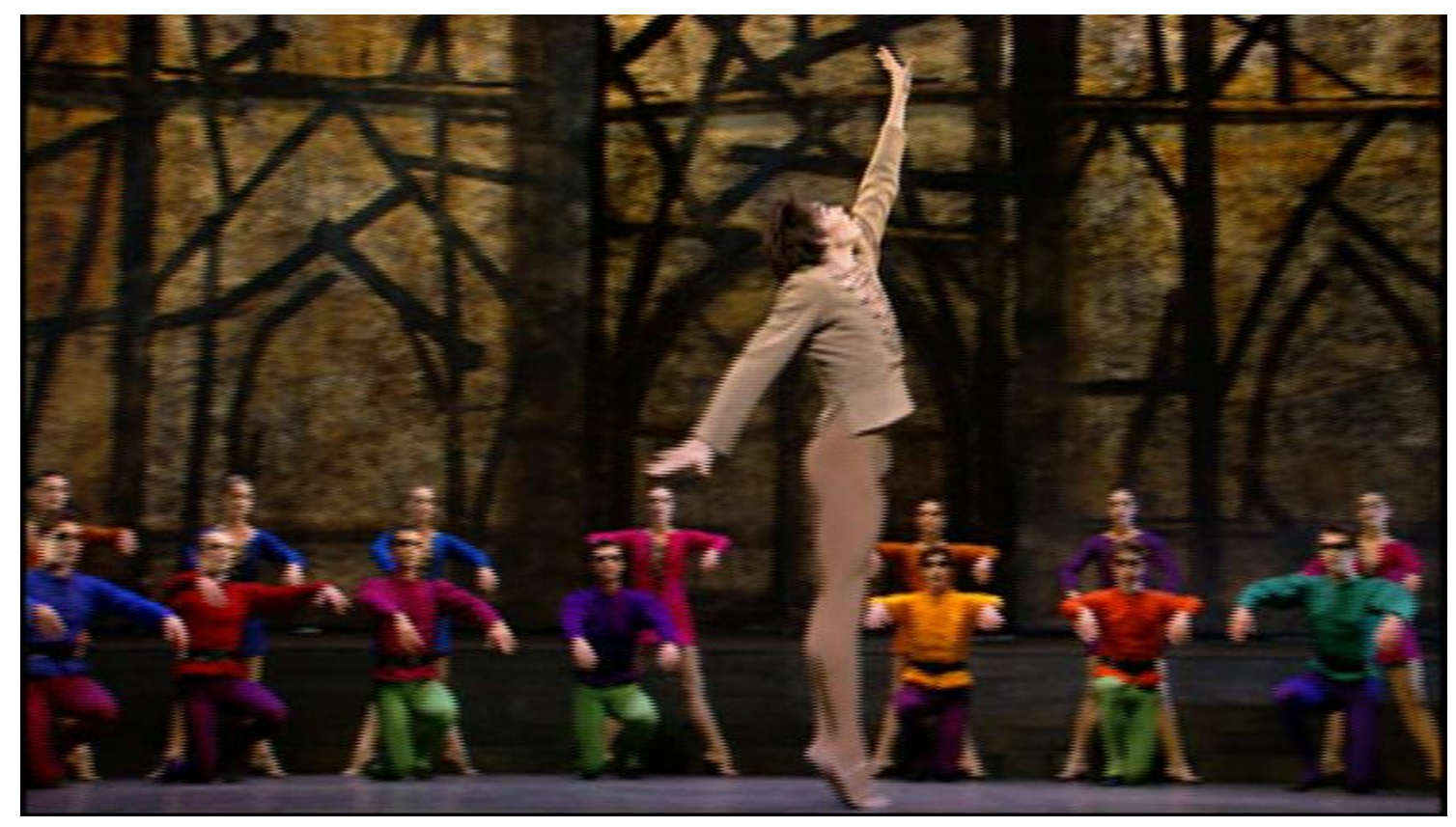

Figura 32 - Quasimodo, em Notre-Dame de Paris, 1996

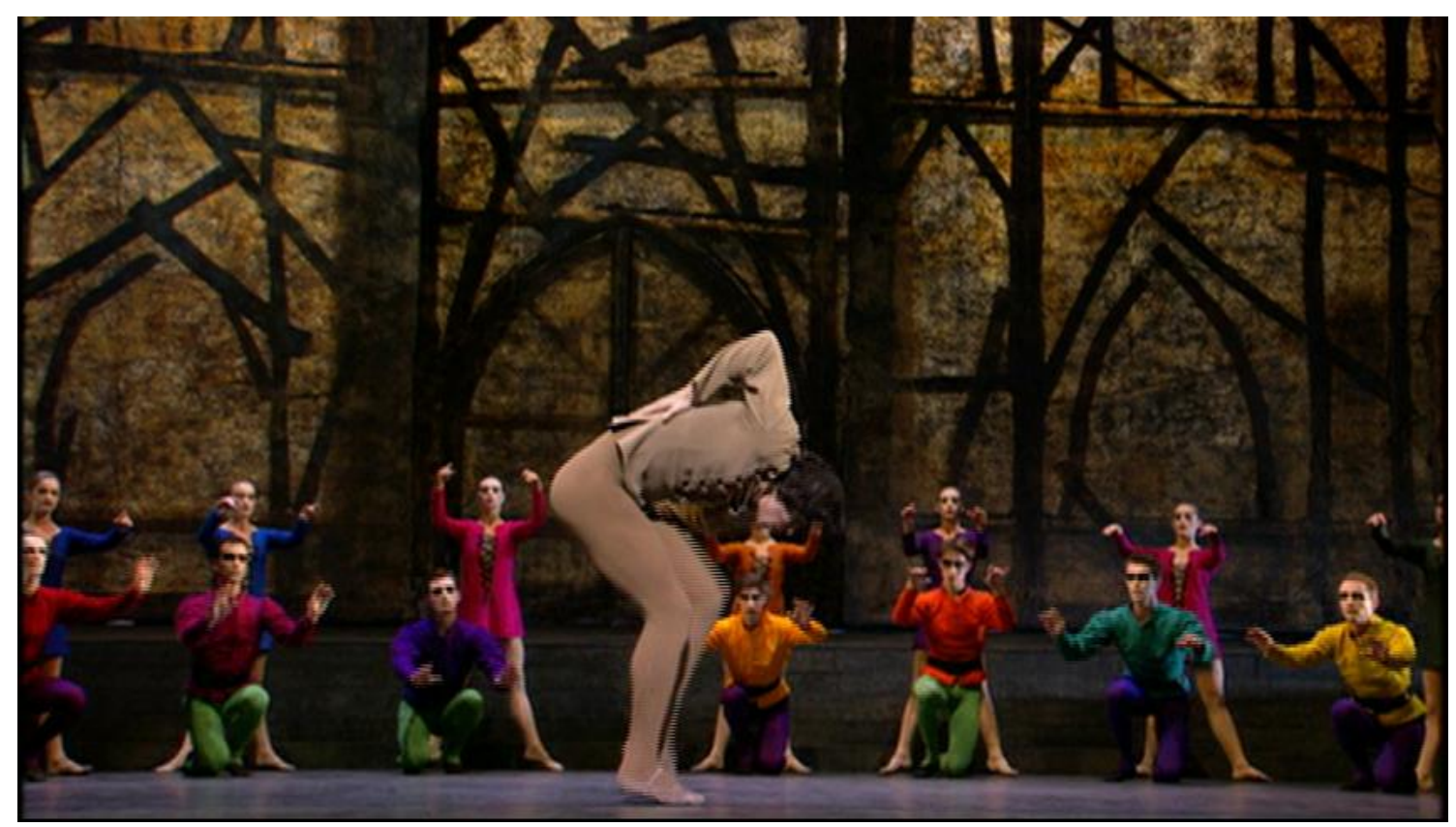

Figura 33 - Quasimodo, em Notre-Dame de Paris, 1996

É importante salientarmos que embora a escrita gestual de Quasimodo seja composta por posições corporais angulares que representam sua deformidade física, sua gestualidade é fluída. Percebe-se uma delicadeza em seus movimentos desajeitados. A naturalidade de sua dança aliada à expressão de medo e ternura no rosto do bailarino permite que o público possa, desde o início do balé, depreender a beleza da alma de Quasimodo, identificando a dualidade deste personagem. 
Embora o Quasimodo da narrativa coreográfica seja um indivíduo com menos deformidades que o personagem da obra literária, sua natureza física não deixa de ser monstruosa. E, assim como em Victor Hugo, sua fealdade não deixa de exercer um papel contestador. De acordo com Barreto (2006), a feiura assim como as deformidades físicas, ao quebrarem o ideal de regularidade das formas, promove uma revolução.

A fealdade quebra o ideal de regularidade das formas físicas dos personagens, assim como das formas do texto e dos esquemas de escritura; o que representa uma novidade à época da aparição desses textos. Sob o ponto de vista filosófico, essa feiura, elevada até ao grotesco e ao monstruoso, colocada no texto por Hugo no mesmo nível de valor estético que o belo, contraria os modos e toda a visão tranquilizante de mundo, além de questionar a ordem dos valores convencionais. ${ }^{121}$

De certa forma, Roland Petit, mesmo que não intencionalmente, questiona alguns dos valores da dança neoclássica. A escritura da gestualidade promovida por ele para a construção de Quasimodo desafia não apenas a rigidez do balé, mas também quebra determinadas convenções, uma vez que o herói do balé é um ser monstruoso, o qual não segue o padrão dos heróis de balés narrativos. Nesse estilo, o protagonista do espetáculo geralmente não realiza movimentos fora das regras do balé clássico, convenção essa que Quasimodo descumpriu, tendo em vista que seus movimentos, em sua maioria, não pertencem a essa escola. Logo, respeitando-se o contexto e a modalidade que se insere o balé em análise, podemos considerar o Quasimodo da narrativa coreográfica um ser subversivo, o qual desafia o valor estético do que é considerado belo na dança.

Por sua vez, Frollo também é concebido a partir de uma vasta gama de gestos, a qual possibilita ao espectador não apenas a identificação de sua função de padre, mas também o reconhecimento de sua personalidade sombria. A escrita coreográfica desse personagem baseia-se em gestos precisos e rápidos. Sua movimentação em cena segue sempre percursos bem traçados e angulares. Suas variações ao longo do balé apresentam a alternância entre movimentos frenéticos e momentos de imobilidade.

A primeira aparição em cena de Frollo ocorre durante a sequência $A$ oração. $\mathrm{O}$ então arquidiácono de Notre-Dame interrompe os festejos populares para lembrar ao povo de que a vida não é feita somente de prazeres e que é preciso rezar e se arrepender. Frollo surge em cena com as mãos em posição de oração, o que permite facilmente a identificação por parte do público de sua ocupação. No entanto, essa gestualidade

${ }^{121}$ BARRETO, 2006, p. 140 (tradução nossa) 
característica do personagem faculta ainda outras analogias. Além de evocar sua função, a posição das mãos em oração pode ser entendida como o símbolo do autocontrole, da frieza e da severidade de Frollo, uma vez que ela contrastará com o fremir de suas mãos ao escutar o som do tamborim de Esmeralda - a gestualidade símbolo de sua paixão pela jovem cigana, como analisaremos no item a seguir. Logo, ao retornar suas mãos para essa posição, Frollo parece recuperar o controle de suas emoções bem como de sua razão, dissimulando sob o aspecto da frieza e da severidade, sua alma atormentada.

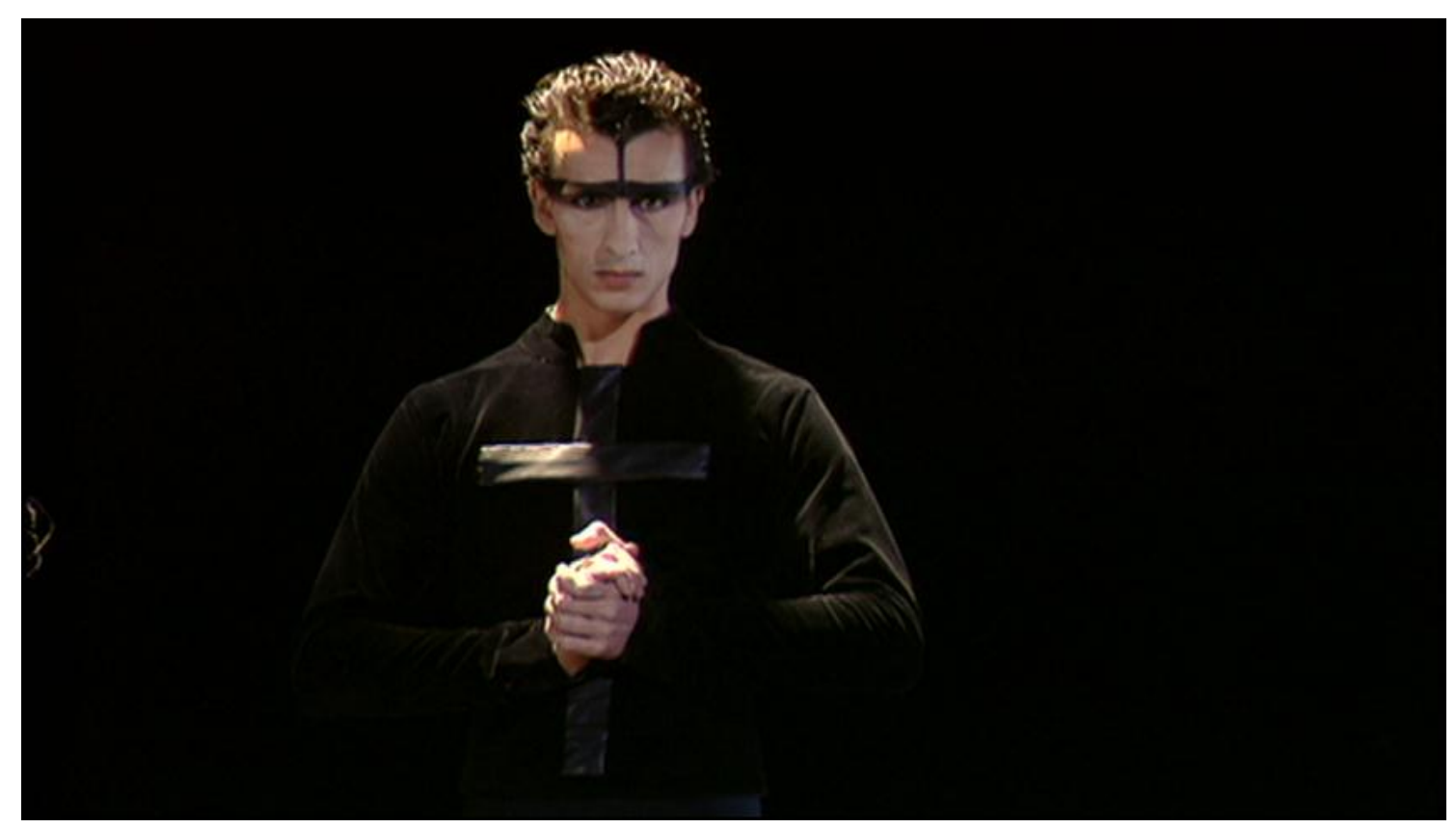

Figura 34 - Frollo em sua gestualidade característica, em Notre-Dame de Paris, 1966

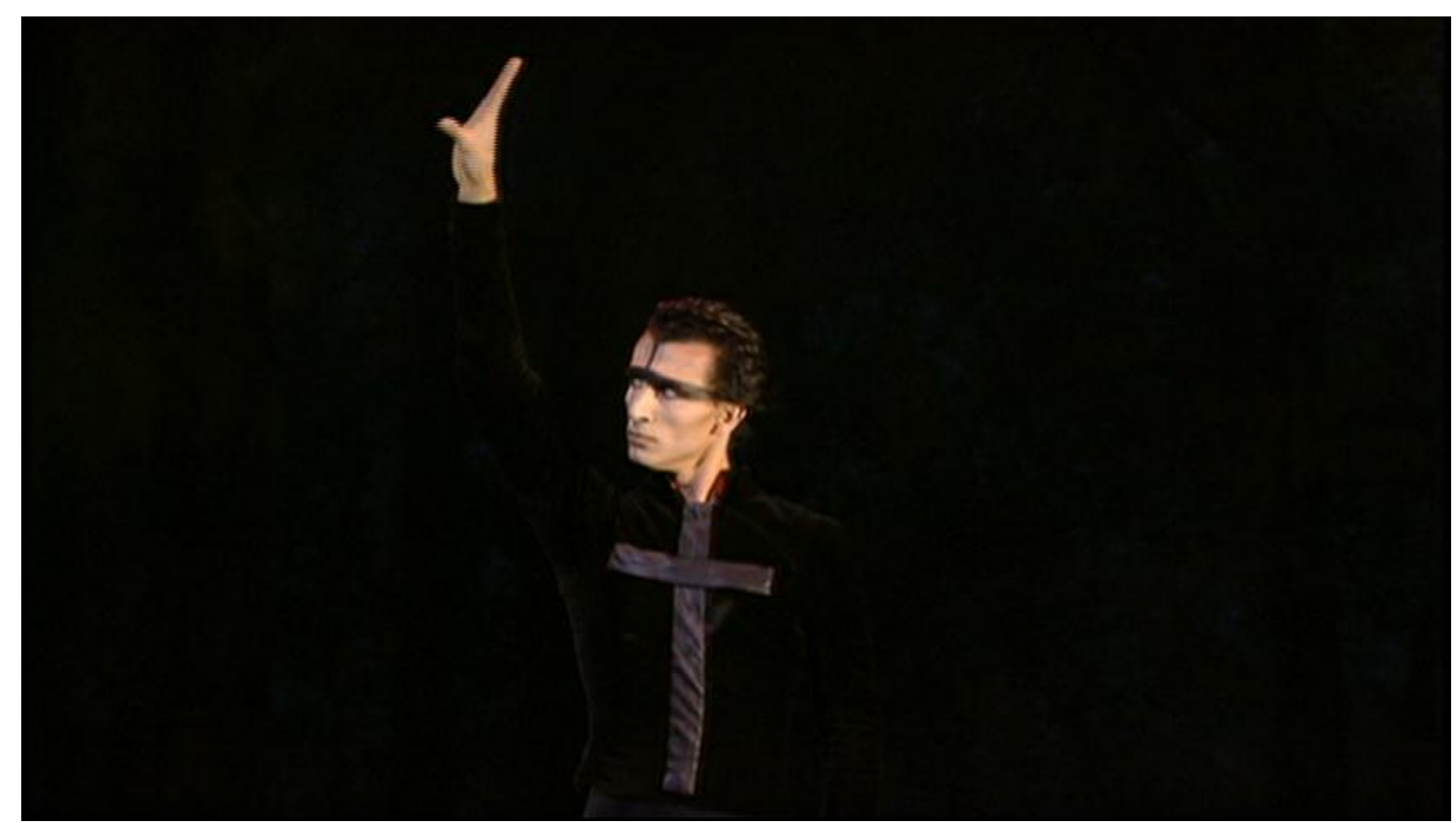

Figura 35 - O fremir de mãos de Frollo, em Notre-Dame de Paris, 1996 
Diferentemente de Quasimodo, a gestualidade de Frollo intercorre, em sua maioria, no plano superior do palco. Sua escrita coreográfica é composta por diversos saltos e piruetas, executados sempre com o tronco esticado, o que nos remete a postura austera de um padre. É interessante notar como Quasimodo e Frollo alternam seus movimentos nesses dois planos. Quasimodo mantém-se agachado diante de Frollo em praticamente todo o balé, ocupando o plano médio do palco. Essa posição proporciona o entendimento da relação desses dois personagens. Bebê abandonado, prometido à fogueira por algumas comadres que viam em sua monstruosidade um sinal do Diabo, Quasimodo foi recolhido e criado por Frollo. Graças à ajuda do arquidiácono, Quasimodo escapa da morte e torna-se o tocador de sino da catedral. A gratidão de Quasimodo aliada ao sentimento de dívida pela sua vida faz com que o personagem cultive uma relação de submissão em relação ao padre. Esse vínculo de mestre e cão fiel é marcado no balé justamente pelo contraste dos planos de palco ocupados por esses dois personagens.

A faceta misteriosa e sombria de Frollo também é ressaltada pela sua gestualidade. Sabe-se que no romance hugoano, Frollo é descrito como "um padre austero, grave, moroso" ${ }^{\prime 22}$. Sua figura estranha causava medo nas crianças e alimentava os rumores de seu envolvimento com a bruxaria. Essa caracterização do personagem é reproduzida na dança por meio da precisão e da agilidade dos gestos do bailarino. Durante o balé, Frollo aparece e desaparece de cena sem deixar vestígios e, em alguns momentos, permanece ao lado de Esmeralda sem que esta perceba sua presença, como uma espécie de animal predador à espreita de sua caça. Esses momentos de imobilidade em cena, observando Esmeralda, contribuem ainda mais para a construção da figura sinistra de Frollo.

${ }^{122}$ HUGO, 2009, p. 939 


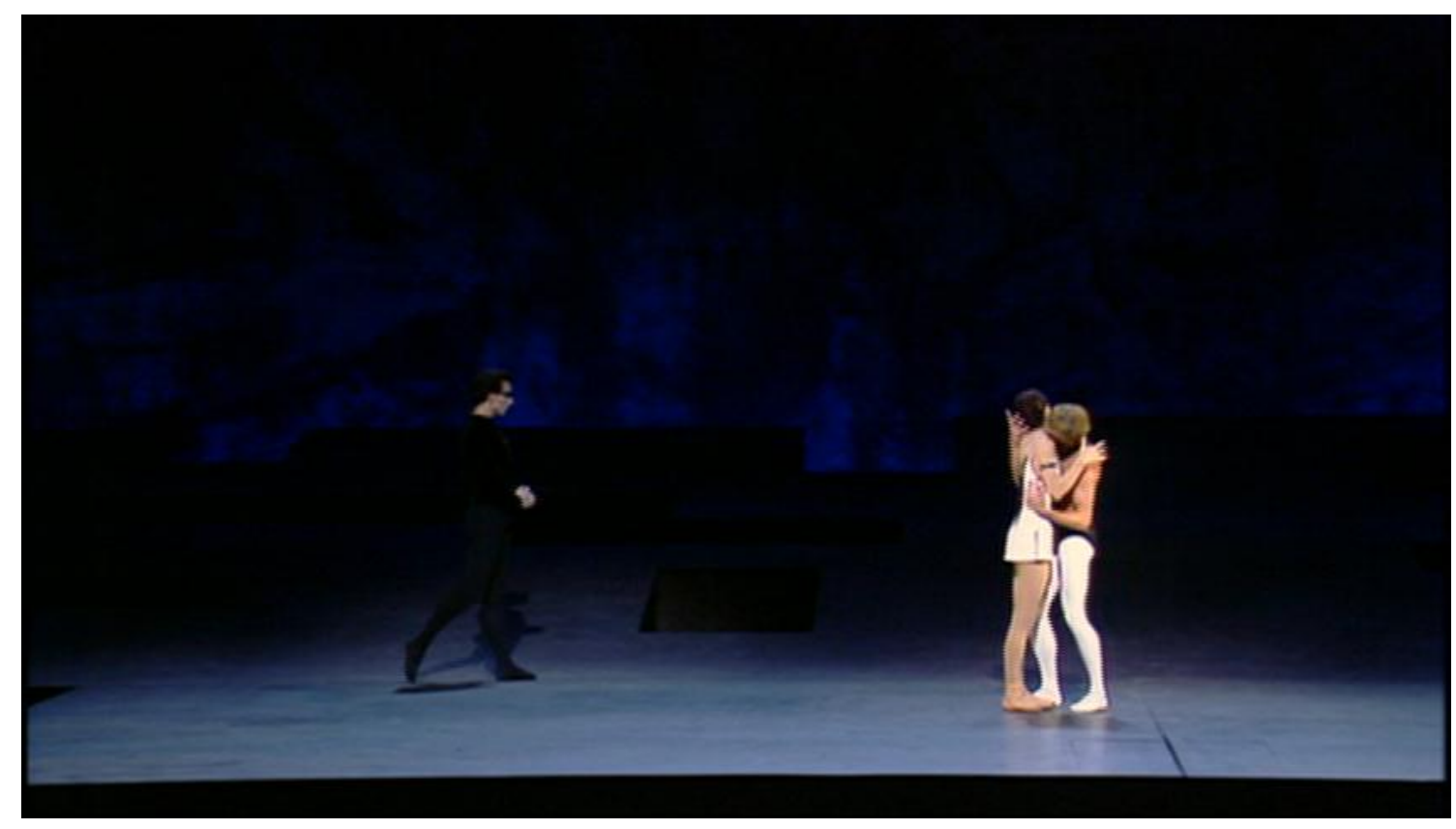

Figura 36 - Pas-de-trois entre Esmeralda, Frollo e Phoebus, em Notre-Dame de Paris, 1996

Ademais, é importante salientarmos que, diferentemente do romance, não nos é dado o conhecimento sobre as origens de Frollo nem sobre as circunstâncias que o levaram até àquela posição. A única informação que o espectador possui, por meio do livreto, é a de que padre recolheu Quasimodo ainda criança e o criou. Logo, não sabemos as razões que construíram o caráter sinistro do personagem na narrativa coreográfica, e que, por conseguinte, levá-lo-á a cometer crimes e ações monstruosas ao longo da trama.

Completando a tríade de personagens masculinos do balé Notre-Dame de Paris, temos Phœbus. Dentre os principais personagens, este parece ser o que tem a escrita coreográfica menos elaborada, até mesmo porque seu papel na narrativa é quase secundário. Ele é necessário para o desfecho do balé, no entanto sua personalidade e sua história não são plenamente desenvolvidas. Na narrativa coreográfica, Phœbus é retratado como um soldado sedutor, o qual alimenta uma paixão carnal por Esmeralda. Sua primeira aparição em cena ocorre na sequência Os soldados, na qual desfila liderando suas tropas. Orgulhoso e confiante, Phœbus exibe-se para Esmeralda e para o público, no que Roland Petit classifica como uma "parada amorosa". Nota-se que neste momento, a gestualidade de Phœbus segue os padrões acadêmicos do balé clássico. Sua 
sequência é composta por diversos saltos e tours en l'air ${ }^{123}$. Tais movimentos evidenciam a vaidade e o orgulho do personagem, que ostenta seu poder e suas habilidades como capitão.

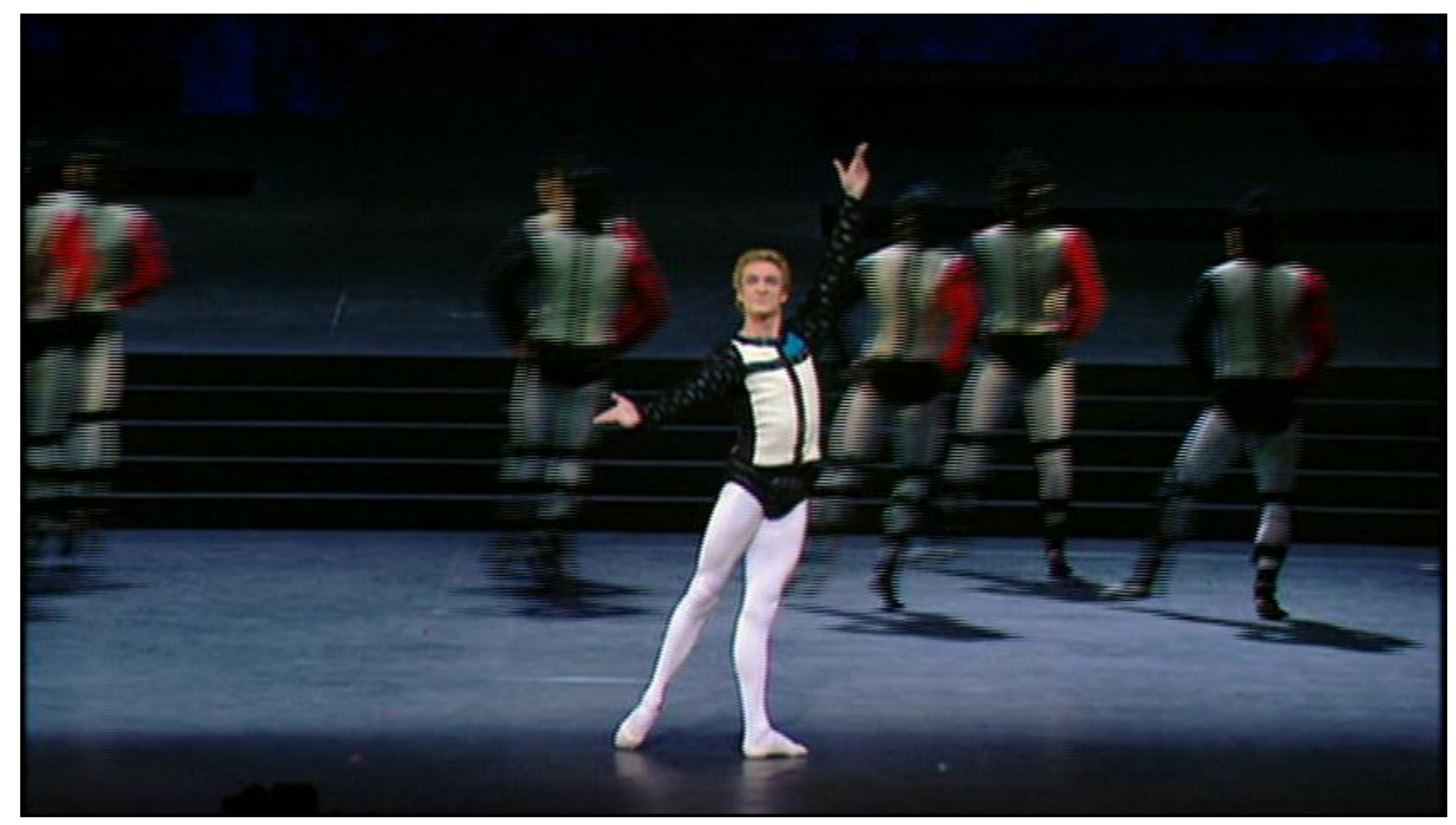

Figura 37 - Manuel Legris como Phoebus, em Notre-Dame de Paris, 1996

Quanto a Esmeralda, sabemos que ela é fruto do desejo desses três homens. Roland Petit buscou construir uma imagem diferente da personagem hugoana, afinal a Esmeralda da narrativa coreográfica é uma mulher ora frágil ora fatal. A fim de construir essa figura ambivalente, Roland Petit serviu-se de gestualidades que perpassam desde a dança clássica até movimentos que remetem à dança egípcia; tudo aliado à dramaticidade expressa pela bailarina. De fato, grande parte de seus movimentos aproximam-se da dança clássica, até mesmo porque, durante a maior parte do balé, a intérprete usa uma sapatilha de ponta, característica desse estilo de dança. No entanto, Esmeralda também executa alguns movimentos segmentados - quando há a ruptura da linha alongada da dança clássica. Essa gestualidade é composta basicamente de poses lascivas proporcionadas por um jogo de movimento de pernas que alternam nas posições en dehors ${ }^{124}$ e en dedans. A união dessas poses e da dança clássica produz

\footnotetext{
${ }^{123}$ Volta no ar. Em geral, passo para o bailarino homem. Saindo de 5a posição (ou qualquer outra, em geral $2 \mathrm{a}$ ou 5a) no demi-plié, o bailarino dá um salto para cima com as pernas bem juntas ao mesmo tempo em que vira uma ou mais voltas no ar com o corpo.

${ }^{124}$ Para fora. Indica que: (a) o movimento da perna é feito em direção circular da frente para trás; (b) uma pirueta é executada girando-se para o lado da perna que levanta do chão.
} 
uma sensualidade velada para a personagem, fazendo com que a Esmeralda de Roland Petit seja mais realista que a Esmeralda do romance hugoano.

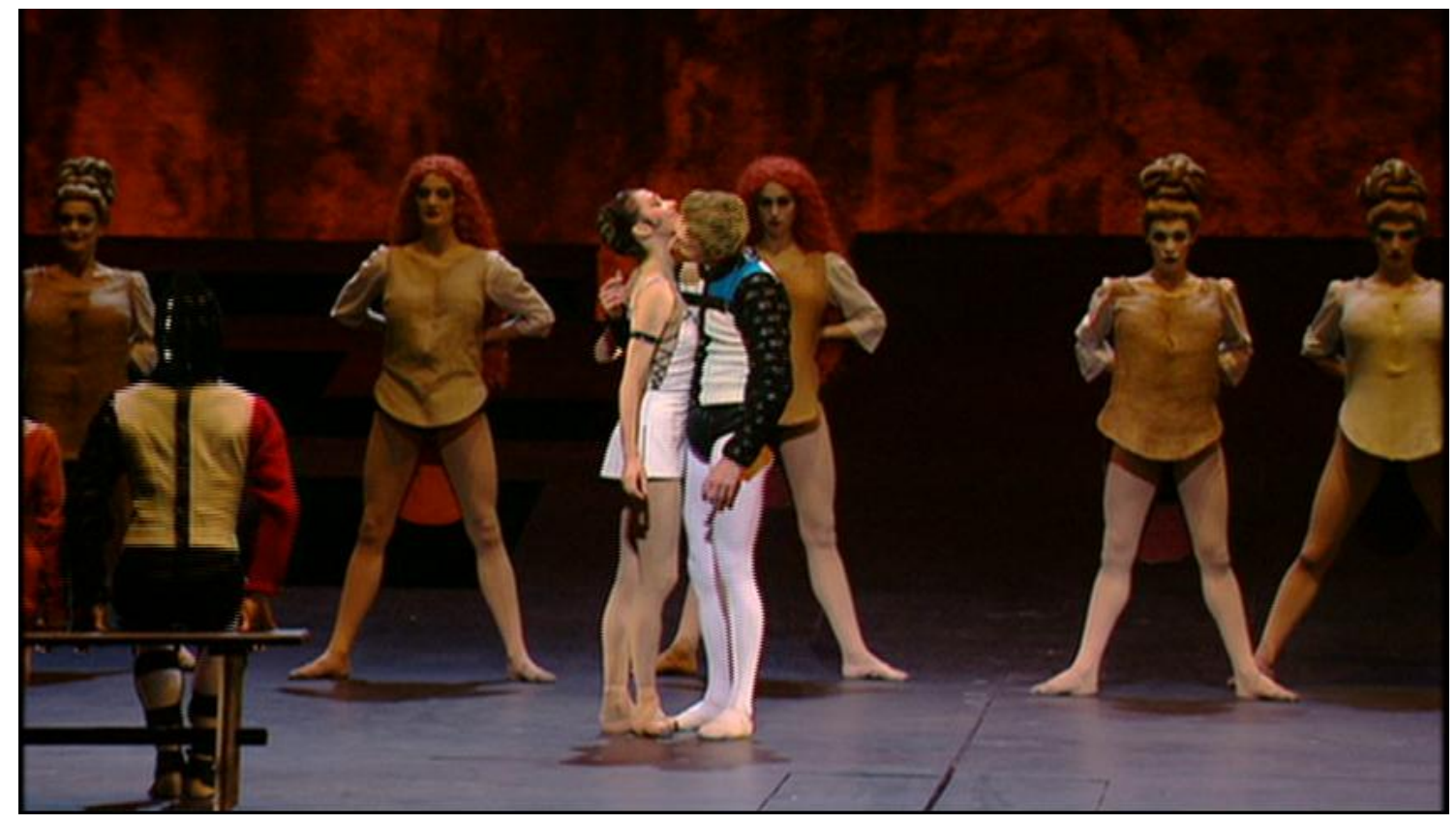

Figura 38 - Esmeralda e Phoebus, em Notre-Dame de Paris, 1996

\subsubsection{Monstruosidade e amor: a escrita pelo corpo}

A escolha de adaptar Notre-Dame de Paris exaltando o viés trágico da obra hugoana, revela-nos muito a respeito do entendimento de Roland Petit sobre esse romance. Para ele, Notre-Dame de Paris pode ser entendido, em sua essência, como uma história de amor, em que três personagens masculinos gravitam em torno de uma personagem feminina principal.

Essa concepção adotada ao recriar a narrativa textual para a dança implica em uma série de fatores. Primeiramente, não é possível observar no balé todos os outros temas retratados por Victor. As questões históricas e filosóficas, assim como manifesto em prol da preservação da arquitetura gótica são deixados de lado na narrativa coreográfica. De fato, Roland Petit concebe Notre-Dame de Paris, como uma espécie de conto moderno, uma variação sobre o tema do amor e da morte.

Sua narrativa estrutura-se nas relações de amor e paixão estabelecidas entre os personagens assim como em seus efeitos e consequências. Cada personagem masculino mantém com Esmeralda uma relação de natureza amorosa, as quais variam em diferentes intensidades entre o amor incondicional à paixão destruidora. Essas diversas 
nuances de sentimentos aparecem claramente nas interações entre esses personagens e nas gestualidades por eles executadas.

Assim, o balé de Roland Petit pode ser analisado a partir das diferentes relações amorosas estabelecidas com Esmeralda, a saber: o amor de Quasimodo por Esmeralda, a paixão obsessiva de Frollo pela jovem cigana e o interesse carnal que liga Phœbus à Esmeralda.

\subsection{Quasimodo e Esmeralda: a aliança dos contrários}

A narrativa coreográfica de Roland Petit recria através da gestualidade a relação amorosa de Quasimodo e Esmeralda, marcada tanto no romance quanto na dança pela aliança dos contrários. Sabemos que, na narrativa textual, Esmeralda e Quasimodo são dois personagens antitéticos: Esmeralda é concebida como a personificação da beleza, enquanto que Quasimodo é considerado um ser monstruoso devido à sua fealdade e a suas deformidades físicas.

A antítese complementar desses personagens e as questões que permeiam o seu relacionamento da narrativa coreográfica são especialmente recriadas durante o pas-dedeux do segundo ato intitulado Esmeralda e Quasimodo. Essa sequência, em que Esmeralda conduz Quasimodo em sua dança amorosa, revela, ao mesmo tempo, o contraste entre os dois personagens e a sua complementaridade.

No início do pas-de-deux, a gestualidade de Quasimodo e Esmeralda é concebida de forma a ressaltar a disparidade entre ambos. Enquanto a gestualidade de Esmeralda revela sua graça e elegância, a movimentação de Quasimodo evidencia ainda mais sua deformidade física. Tal contraste é construído a partir de uma movimentação oposta. Esmeralda executa movimentos longilíneos e graciosos, respeitando a gramática clássica, ao passo que Quasimodo realiza movimentos quebrados, valorizando o plano médio do palco e enfatizando sua condição física. A oposição entre esses dois

personagens é reforçada neste momento também pela música que alterna entre o leimotiv de Quasimodo e o leimotiv de Esmeralda. 


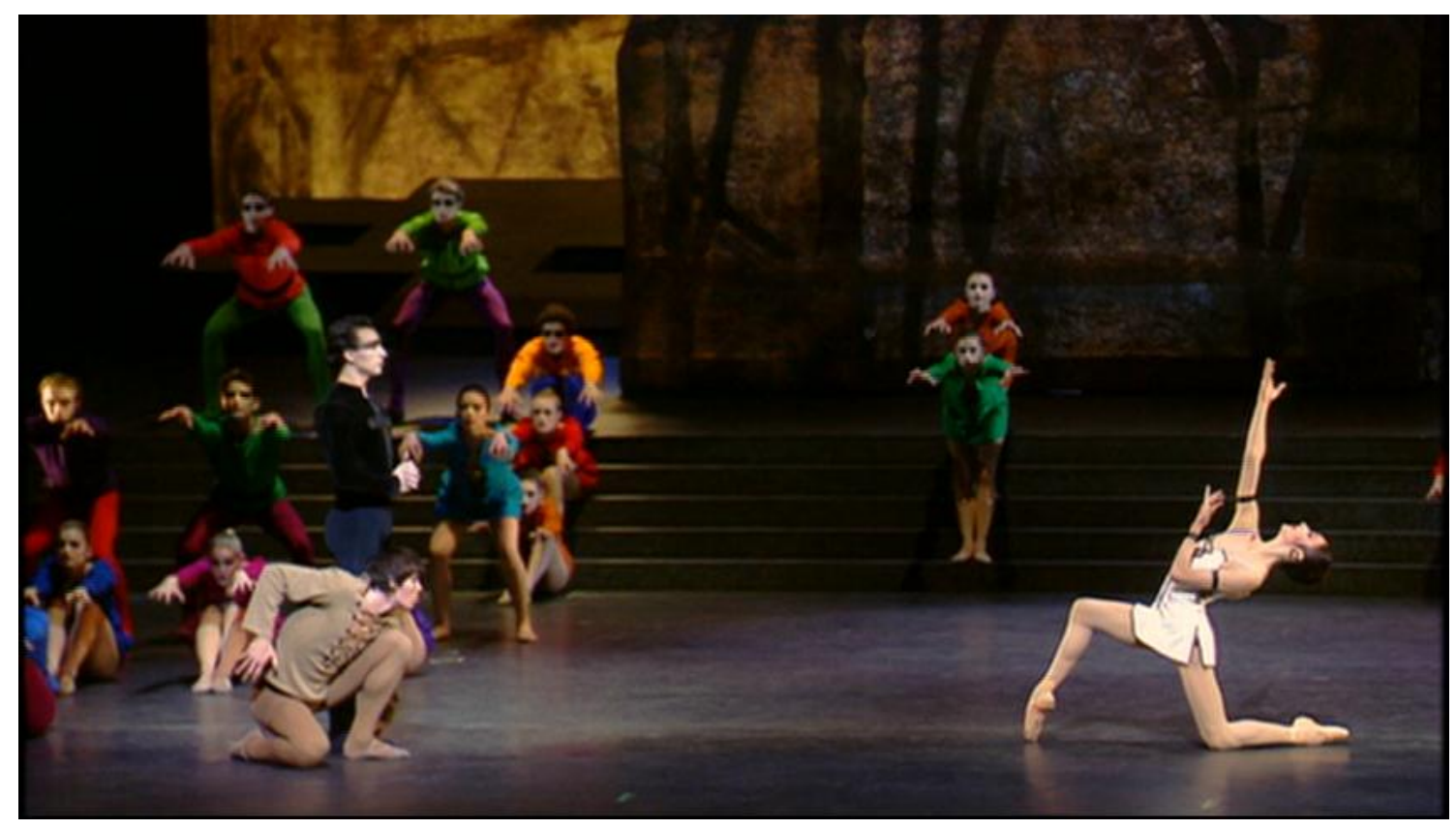

Figura 39 - Esmeralda e Quasimodo, em Notre-Dame de Paris, 1996

No entanto, ao longo dessa sequência, podemos observar que, embora díspares, os movimentos de Quasimodo e Esmeralda se complementam. A união dessas gestualidades diferentes, porém complementares, parece-nos, de certa forma, uma metáfora dos laços que unem esses personagens. De acordo com Jacques Seebacher, "esses personagens representam duas figuras antitéticas do povo como exclusão."125 Apesar de aparentemente opostos, Quasimodo e Esmeralda possuem algo em comum: são dois seres rejeitados, marginalizados pela sociedade.

De fato, o pas-de-deux, Esmeralda e Quasimodo, é de suma importância não apenas para a compreensão dos laços que unem esses personagens, mas também para o entendimento do carácter dual de Quasimodo. Apesar de sua feiura e de suas deformidades físicas, Quasimodo possui uma alma generosa, dotada de belos sentimentos. E é justamente o amor sublime que sente por Esmeralda que coloca em evidência a bondade e a pureza de sua alma.

Ao dançar o duo amoroso com Esmeralda, Quasimodo esboça alguns movimentos verticais, pertencentes ao estilo clássico. Nesse momento, o bailarino livrase de sua deformidade física representada pelo seu corpo, e entrega-se à dança com sua parceira. Logo, o amor platônico que sente pela jovem cigana, aparentemente, liberta-o

${ }^{125}$ SEEBACHER apud BARRETO, 2006, P. 98 
da escravidão de seu corpo defeituoso e permite que ele expresse sua verdadeira essência.

Ademais, podemos observar durante a narrativa coreográfica e especialmente nesse mesmo pas-de-deux que, diferentemente do romance, Esmeralda não esboça um sentimento de medo e horror face à monstruosidade física de Quasimodo. No balé, Esmeralda demonstra um certo temor a Quasimodo apenas em um primeiro momento, durante o quadro Pátio dos Milagres, onde Quasimodo persegue-a pelas ruas de Paris a mando de Claude Frollo. No entanto, tal sentimento logo se transforma em piedade e compaixão no quadro seguinte, quando Quasimodo é açoitado em virtude da perseguição à Esmeralda. Comovida pelo sofrimento do sineiro cujo aspecto a havia inicialmente assustado, a jovem cigana atravessa a multidão para lhe dar de beber. Esse pequeno gesto de consternação diante de Quasimodo - provavelmente o único que já lhe haviam manifestado - toca a alma do pobre diabo e muda o curso de seu destino.

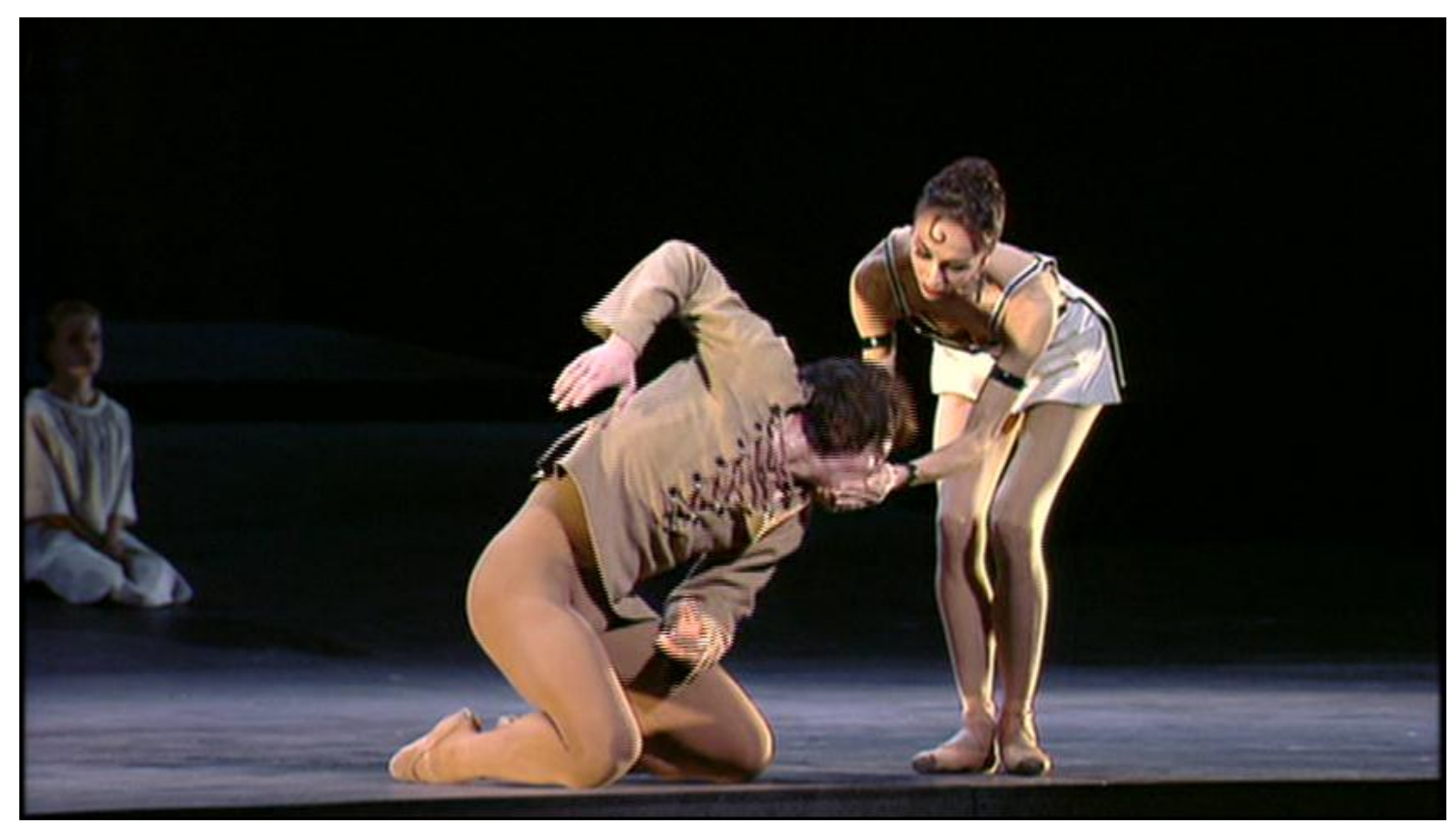

Figura 40 - Esmeralda e Quasimodo, em Notre-Dame de Paris, 1996

Mais adiante, no quadro A forca, Quasimodo retribui o gesto de Esmeralda e salva a pobre cigana condenada à forca por depravação, homicídio e feitiçaria. Ele lhe dá abrigo em Notre-Dame, local de asilo. A atitude do sineiro desperta em Esmeralda um sentimento de gratidão, que é retratado justamente no pas-de-deux Esmeralda $e$ Quasimodo. Durante essa sequência, Esmeralda toca delicadamente o ombro erguido de Quasimodo, símbolo de sua deformidade física. Esse movimento é representativo, uma vez que ele demonstra não apenas a dualidade desses personagens, mas também a 
ternura e o reconhecimento que Esmeralda sente por Quasimodo. De fato, é como se essa gestualidade atestasse definitivamente o carácter bom e gentil do personagem, que motivado por tal atitude toma a mão da jovem dançarina e, "todo feliz, faz as honras do refúgio" $" 126$.

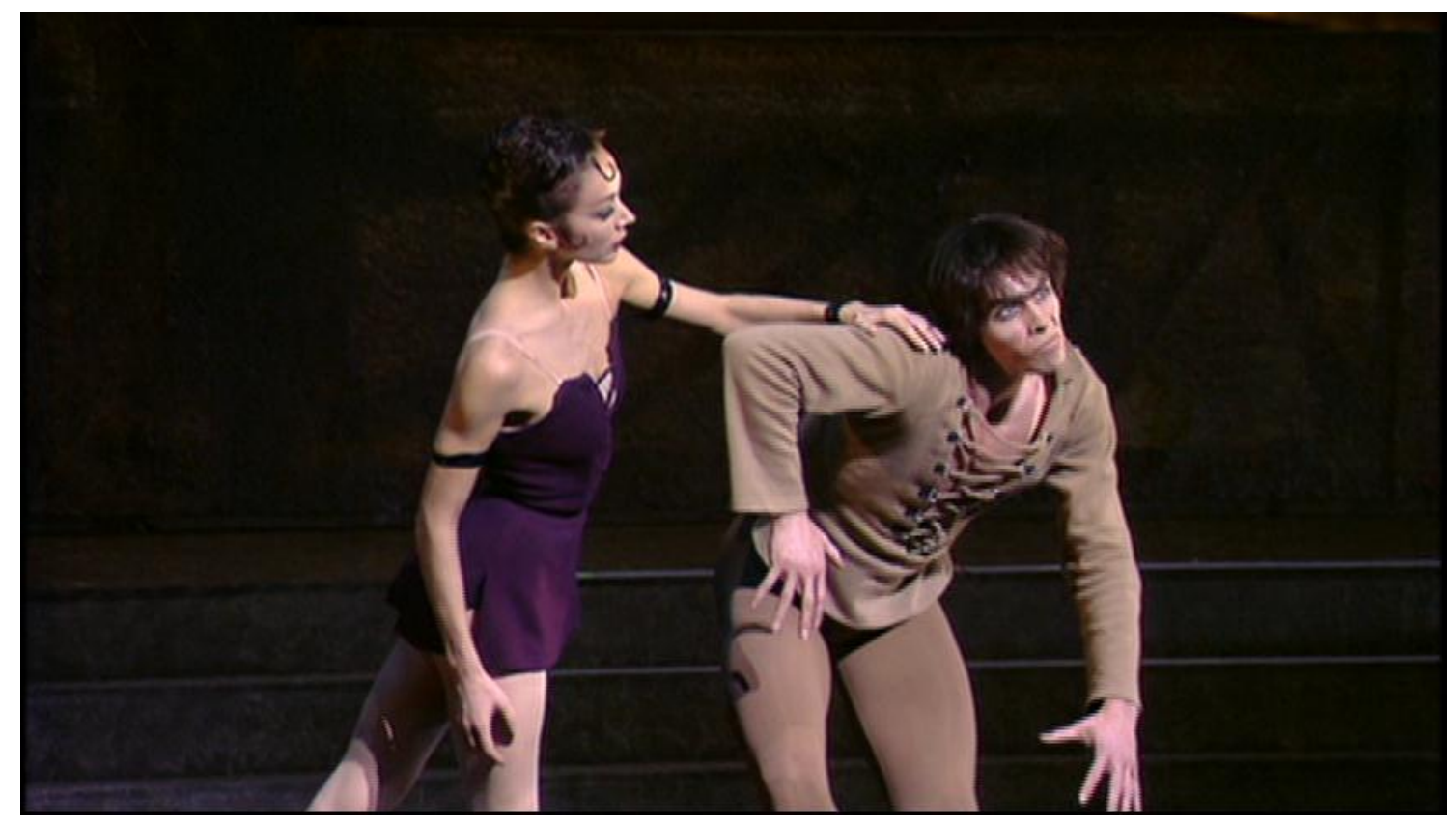

Figura 41 - Esmeralda e Quasimodo, em Notre-Dame de Paris, 1996

O desfecho do pas-de-deux também ocorre de forma a reforçar essa imagem. Após o duo, Quasimodo embala Esmeralda em seus braços, onde ela adormece suavemente, protegida pelo corcunda. Em seguida, ele a coloca no chão e se afasta, acreditando que a jovem estava em segurança naquele ambiente. $\mathrm{O}$ ato de se deixar embalar e dormir no colo de Quasimodo demonstra mais uma vez a ternura e a confiança que Esmeralda sente pelo sineiro. Apesar da fealdade do personagem, é em seus braços que ela encontra tranquilidade e proteção.

O duo Quasimodo e Esmeralda é, na verdade, uma variação sobre o tema do amor. Um amor espiritual, terno, em que personagens antitéticos se encontram e se complementam. Na narrativa coreográfica de Roland Petit, embora Esmeralda não retribua o amor de Quasimodo da mesma forma, ela não deixa de demonstrar seu afeto e reconhecimento por ele. A compaixão e a gratidão que nutre pelo sineiro são, de fato, mais fortes que o sentimento de medo perante as deformidades físicas de Quasimodo.

${ }^{126}$ Trecho do programa de Notre-Dame de Paris. 


\subsection{Claude Frollo e Esmeralda: da paixão à monstruosidade}

Na narrativa coreográfica, Claude Frollo nos é apresentado como o sombrio e severo arquidiácono de Notre-Dame. Sua primeira aparição em cena ocorre durante o quadro $A$ oração, onde o personagem irrompe em meio à multidão para lembrá-la que a vida não é feita somente de prazeres e que é preciso rezar e se arrepender. Neste momento, o padre adentra o palco com as mãos em posição de oração, o que permite ao público identificar sua ocupação e, consequentemente, a obrigação que ela acarreta: a proibição de Frollo cultivar relações íntimas com qualquer mulher. No mais, pouco nos é mostrado a respeito de Frollo durante o balé.

Na obra hugoana, ao perceber Esmeralda dançando diante da catedral, o jovem padre tem suas convicções abaladas e sua alma atormentada por um súbito desejo. Por sua vez, na narrativa coreográfica, tal sentimento é representado pelo fremir das mãos de Frollo que abandona sua gestualidade característica: a posição das mãos em oração.

O som do tamborim de Esmeralda - prelúdio da presença da personagem em cena - faz com que uma das mãos de Frollo se solte e vibre quase que automaticamente ao som deste instrumento. É como uma pulsão incontrolável, um feitiço. Ele tenta segurar sua mão, mas não consegue contê-la.

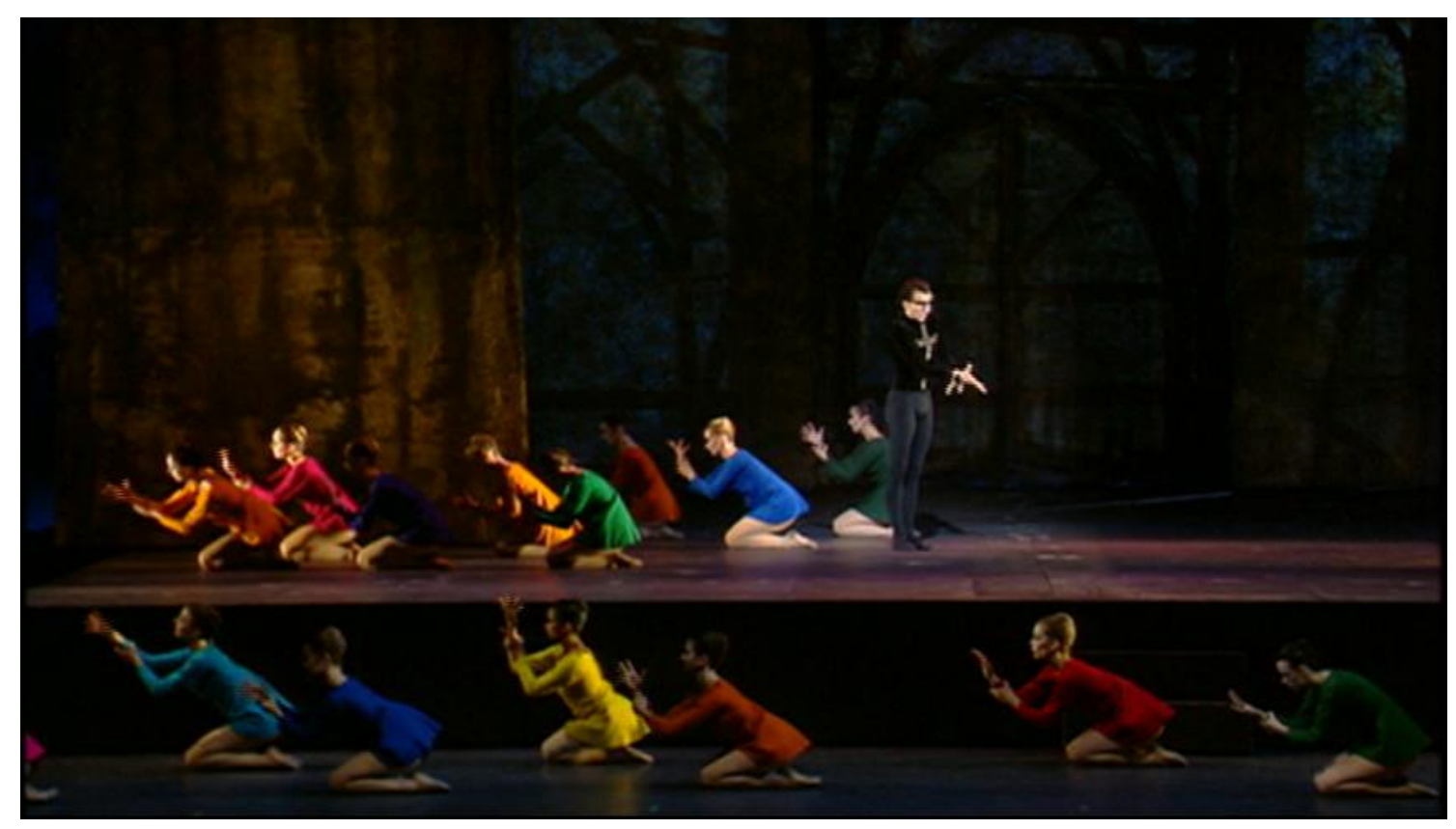

Figura 42 - O fremir de mãos de Frollo, em Notre-Dame de Paris, 1996

$\mathrm{O}$ ato indômito de fremir a mão ao som do tamborim associado à vã tentativa de retornar a sua gestualidade característica - representação de seu posto e de seu 
autocontrole -, simbolizariam sua paixão instantânea por Esmeralda, algo que foge totalmente de seu controle e de sua razão. É possível notar que, ao longo de todo o balé, Frollo é perseguido pelo som do tamborim da jovem dançarina. Logo, a sonoridade desse instrumento acompanhada do vibrar das mãos do personagem torna-se a representação da obsessão e do desejo do padre por Esmeralda na narrativa coreográfica.

De acordo com Jacq-Mioche, essa gestualidade não foi concebida ao acaso por Roland Petit. Amante da literatura, o coreógrafo teria se inspirado em um conto de Gérard de Nerval, de 1832 intitulado A mão encantada. Esse conto fantástico narra a história de Gonin, um cigano que enfeitiça a mão do comerciante Eustache para que ele se saia bem em um duelo, entretanto, a mão passa a ter vontade própria. Após matar seu inimigo e tentar enganar o feiticeiro a quem devia dinheiro, Eustache é condenado à morte por ter esbofeteado sem querer um magistrado a quem havia pedido proteção.

Assim a temática da mão possuída pelo diabo que não obedece mais aos comandos nem do corpo nem da alma - experiência vivenciada por Frollo -, não só demonstra, mais uma vez, os estreitos laços de Roland Petit com a Literatura, como também elucida um certo apreço desse coreógrafo pela estética romântica, movimento do qual Victor Hugo e Gérard de Nerval fazem parte.

Ademais, é importante ressaltar que esse movimento vibratório das mãos de Frollo insere o elemento do inesperado - própria da estética moderna -, ao quebrar a gestualidade clássica que permeia a maioria de seus movimentos. Logo, a tensão e a ambiguidade que perpassam por todas as linguagens do balé são marcadas mais uma vez.

A intensidade e a violência da paixão que acomete Frollo ao avistar Esmeralda na sequência intitulada Esmeralda provocam um tormento em sua alma. Divido entre as obrigações de seu ofício e o desejo que sente pela dançarina, Frollo incorre em uma série de atos violentos contra Esmeralda, os quais culminam na morte de ambos os personagens. De fato, o sofrimento pela rejeição de Esmeralda é maior do que o martírio pela impossibilidade da realização de sua paixão devido aos votos sacerdotais. Esse sentimento de repúdio da dançarina desperta em Frollo uma potência negativa, geradora de sua deformidade moral, ou seja, de sua monstruosidade. 


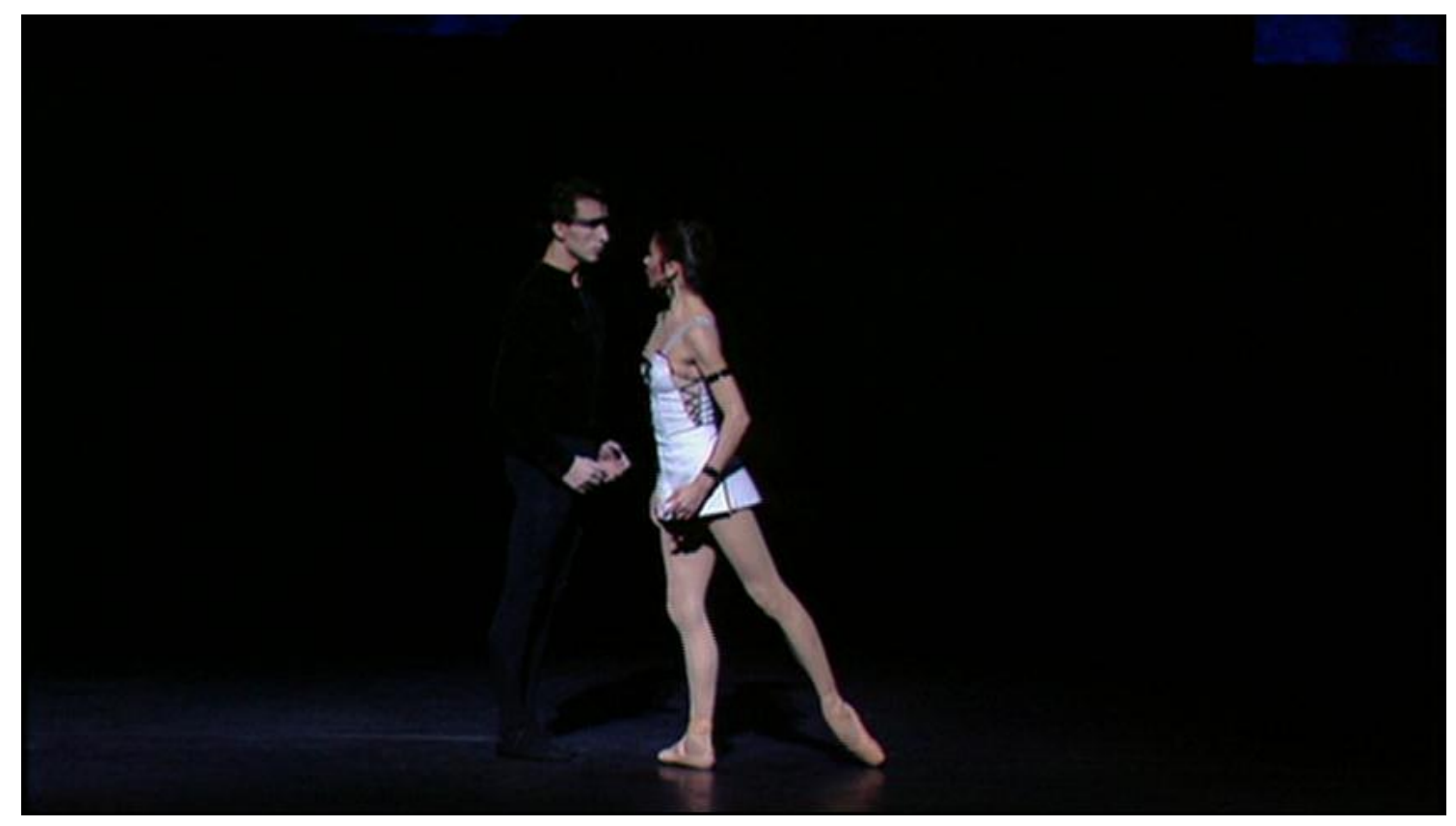

Figura 43 - A rejeição de Esmeralda, em Notre-Dame de Paris, 1996

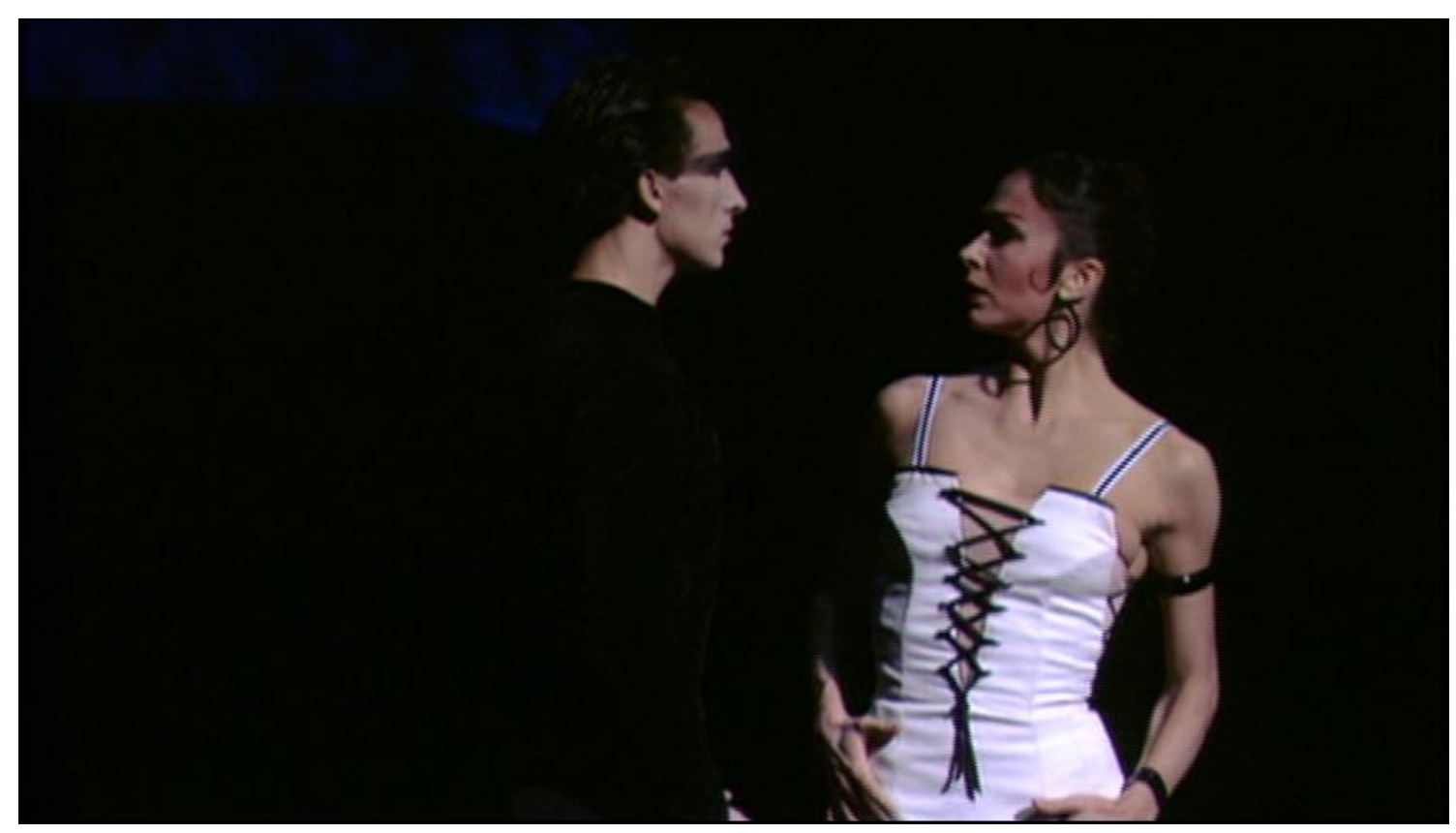

Figura 44 - A rejeição de Esmeralda, em Notre-Dame de Paris, 1996 


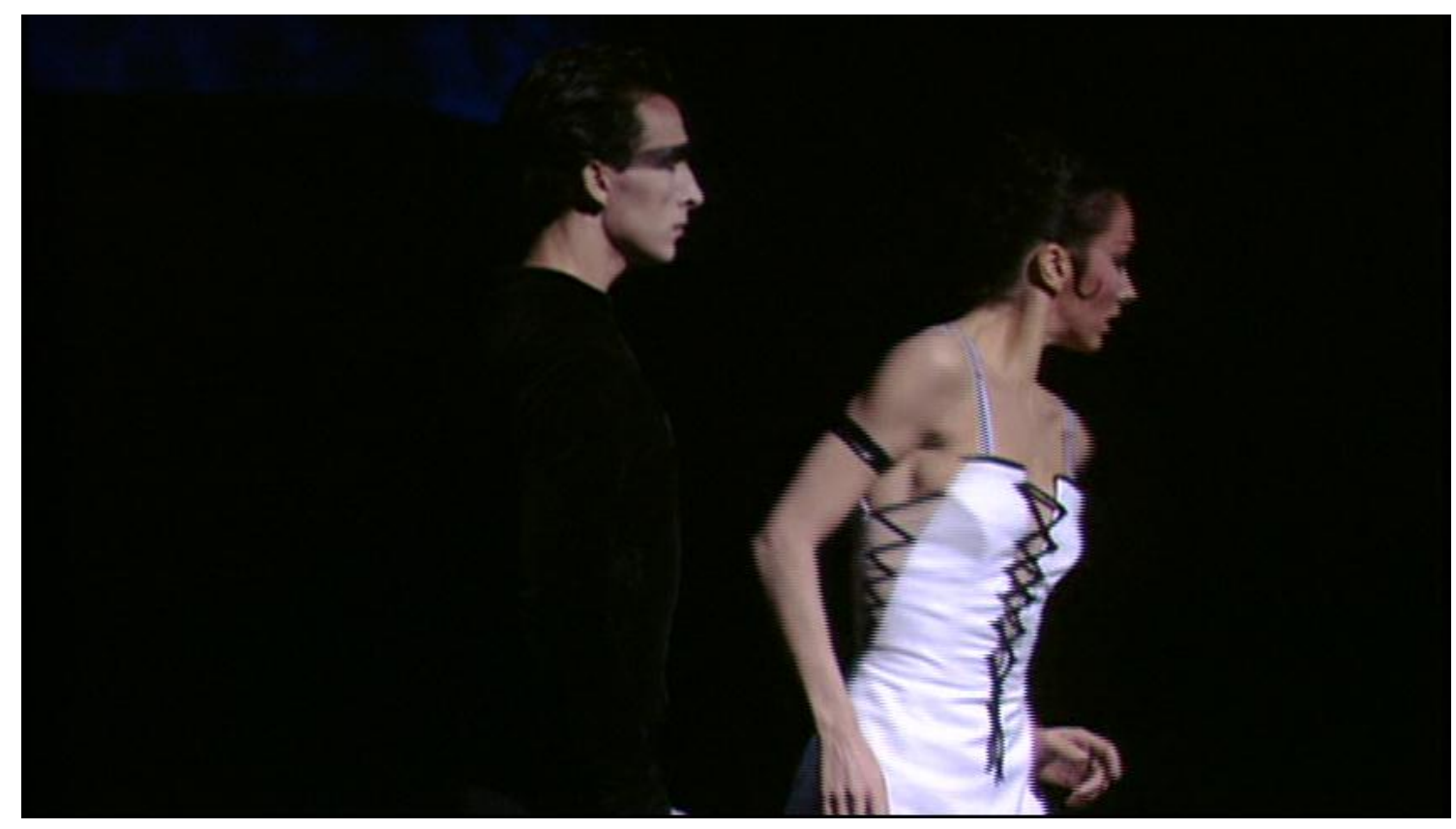

Figura 45 - A rejeição de Esmeralda, em Notre-Dame de Paris, 1996

O desejo doentio de Frollo e o sentimento de medo e repulsa que Esmeralda sente frente ao padre são perfeitamente grafados corporalmente no pas de trois entre Frollo, Esmeralda e Phœbus. Após seduzir a cigana, Phœbus a conduz a taverna para uma noite de amor, todavia Frollo, tomado de raiva e ciúmes, segue-os e assiste, às escondidas, às suas brincadeiras.

A coreografia nessa ocasião alterna de maneira fluída os parceiros masculinos de Esmeralda, que ora é tomada por Frollo ora por Phœbus durante a execução de suas piruetas e portés ${ }^{127}$. Efetivamente, a presença quase espectral de Frollo em cena durante o pas de deux amoroso de Esmeralda e Phœbus associada as troca de partners que eles realizam provoca um efeito interessante. Primeiramente, não sabemos até que ponto a presença do padre é real naquele ambiente ou se tudo não passa de um pesadelo por parte de Esmeralda. Tanto para o público quanto para a Esmeralda, a presença de Frollo só se concretiza após o golpe contra Phœbus, do qual Esmeralda é acusada, uma vez que Frollo foge sem deixar vestígios. A presença intrusiva do padre no pas de deux amoroso do casal consegue, ao mesmo tempo, expor tanto o olhar escondido de Frollo face à situação - o que é narrado no romance-, quanto à dúvida e o pavor de Esmeralda em relação a esse personagem.

\footnotetext{
${ }^{127}$ Carregar. Referência também dada a um passo em que o movimento se estende no espaço produzindo a sensação de prolongamento e vôo no espaço sendo que a pessoa é sustenta por outra durante a execução do passo
} 

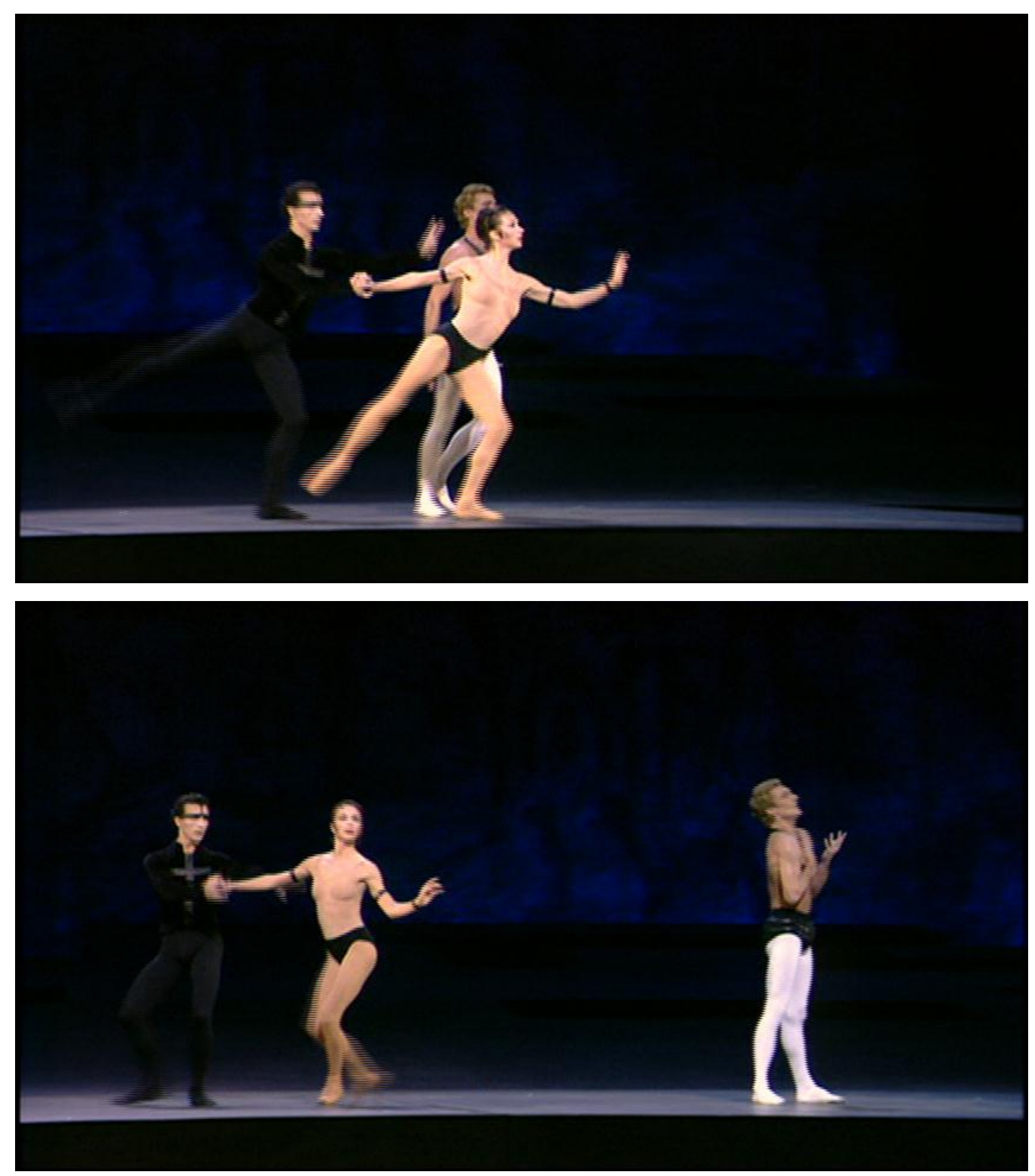

Figuras 46 e 47 - Pas-de-trois entre Esmeralda, Quasimodo e Phœbus, em Notre-Dame de Paris, 1996

A monstruosidade de Frollo concretiza-se, de fato, na narrativa coreográfica durante a sequência Pas de deux Esmeralda e Frollo. Após ser levada a júri e condenada injustamente pela morte de Phœbus, Esmeralda é resgatada por Quasimodo e conduzida à catedral. Apesar da aparente segurança, Notre-Dame também era o lar do arquidiácono. Aproveitando da ausência de Quasimodo, este vem atormentar Esmeralda, a qual rejeita seus abraços e suas carícias. Movido pela sua obsessão e por 
seu delírio passional, Frollo ataca Esmeralda com violência, a fim de acabar para sempre com aquele corpo que lhe resiste.

Embora a descrição da cena sugira um contato direto entre os personagens, Roland Petit opta por recriar esse ataque de um modo figurado na dança. Diferentemente da narrativa hugoana, em um primeiro momento, não há contato físico entre os dançarinos. A recusa de Esmeralda diante das tentativas do padre de beijá-la, faz com que ele se empenhe em dominá-la, o que é reproduzido metaforicamente no balé pela figura do mestre e seu boneco de marionete. Frollo passa a controlar a movimentação de Esmeralda em cena, manipulando-a por meios de gestos que simulam fios invisíveis. Essa imagem é interessante, pois representa o domínio do corpo de Esmeralda por Frollo sem haver nenhuma aproximação física entre os personagens. Tal contato só ocorre no final da sequência quando o padre, em um ímpeto de violência, esbofeteia Esmeralda, que cai desfalecida no palco. O ápice da violência contra a personagem transcorre com o enforcamento dela. Uma vez que Esmeralda não pertenceria a Frollo, ela não seria de mais ninguém.

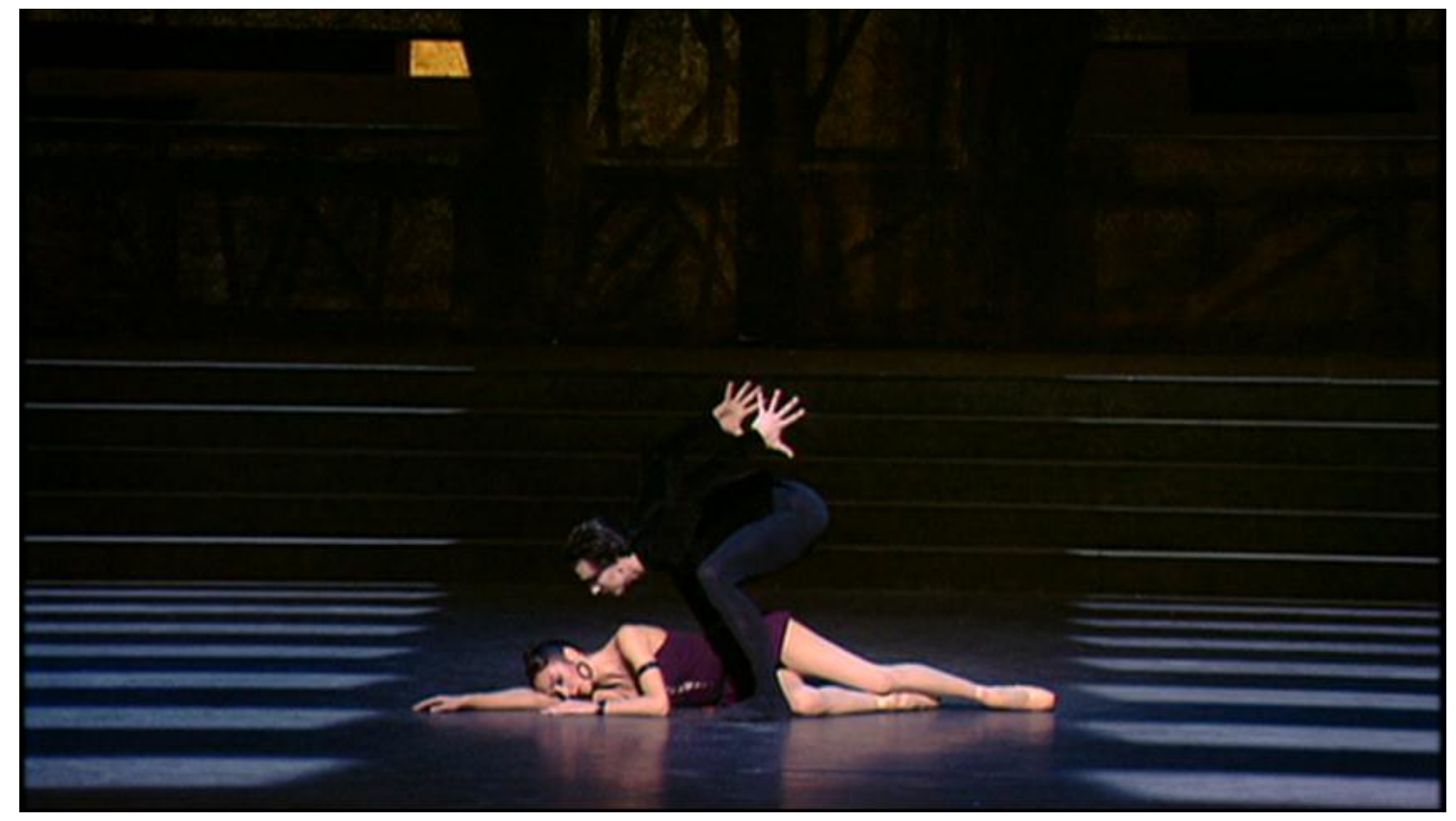

Figura 48 - Frollo manipula Esmeralda, em Notre-Dame de Paris, 1996 


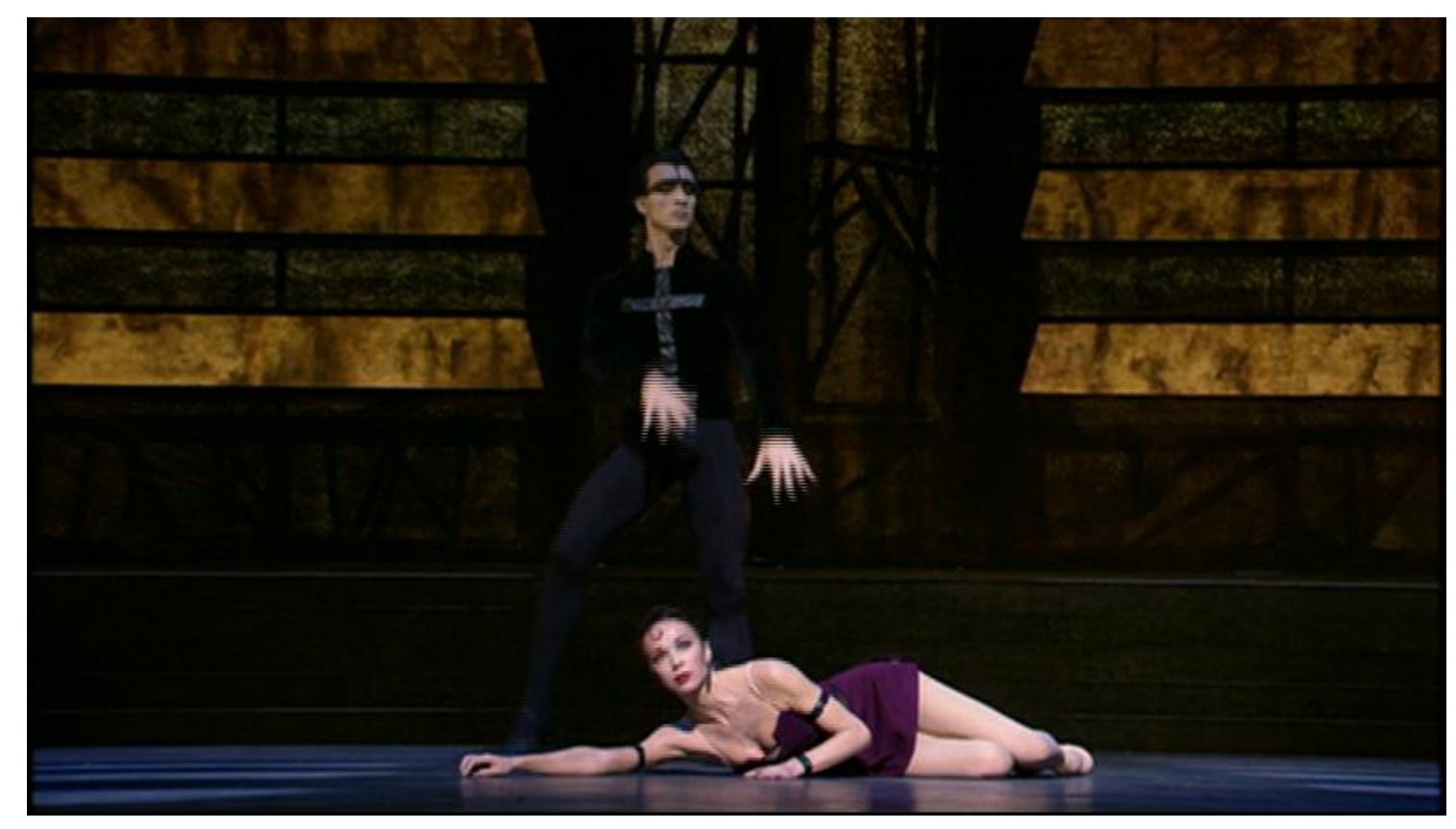

Figura 49 - Frollo manipula Esmeralda, em Notre-Dame de Paris, 1996

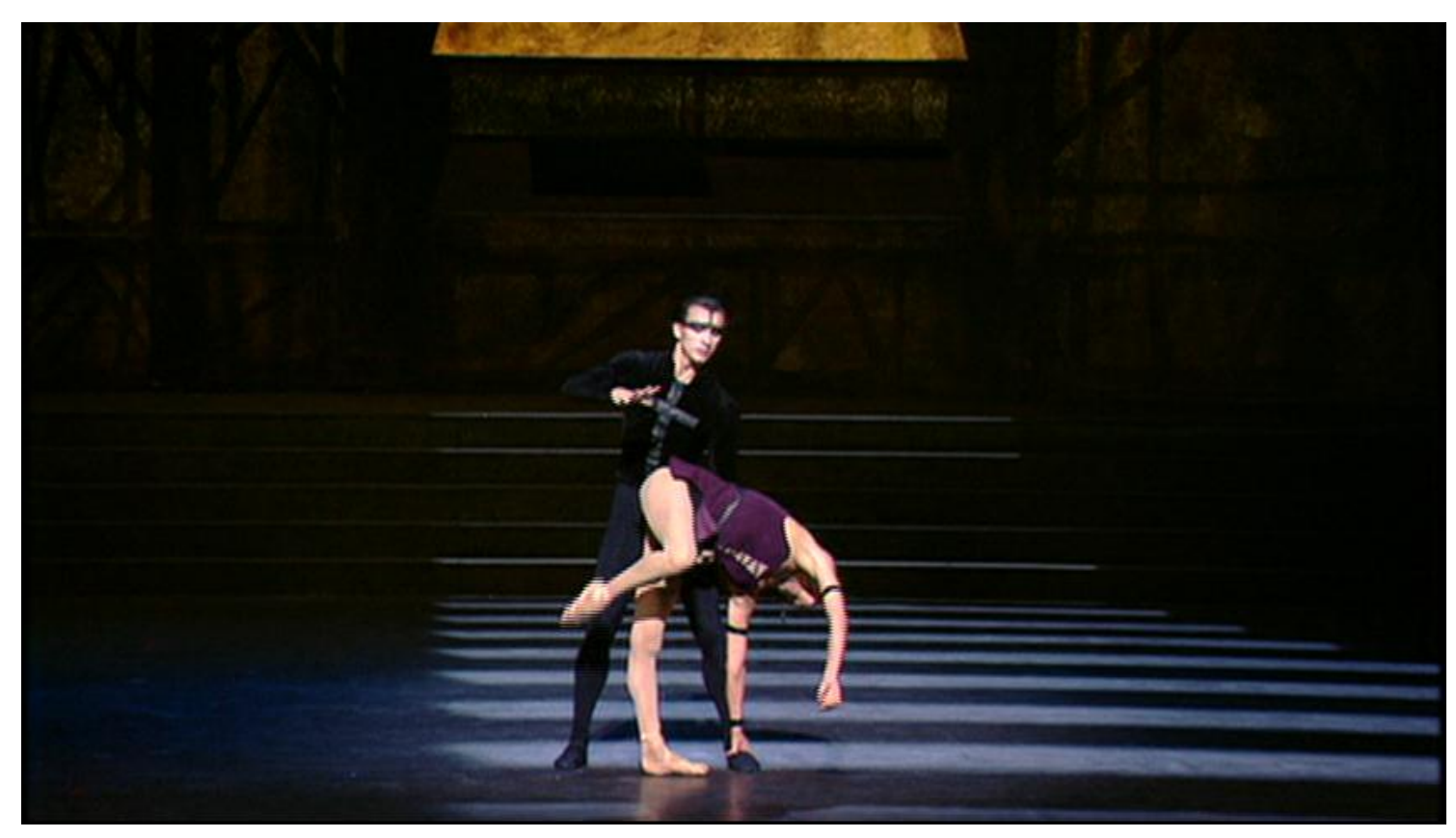

Figura 50 - Frollo persegue Esmeralda, em Notre-Dame de Paris, 1996 


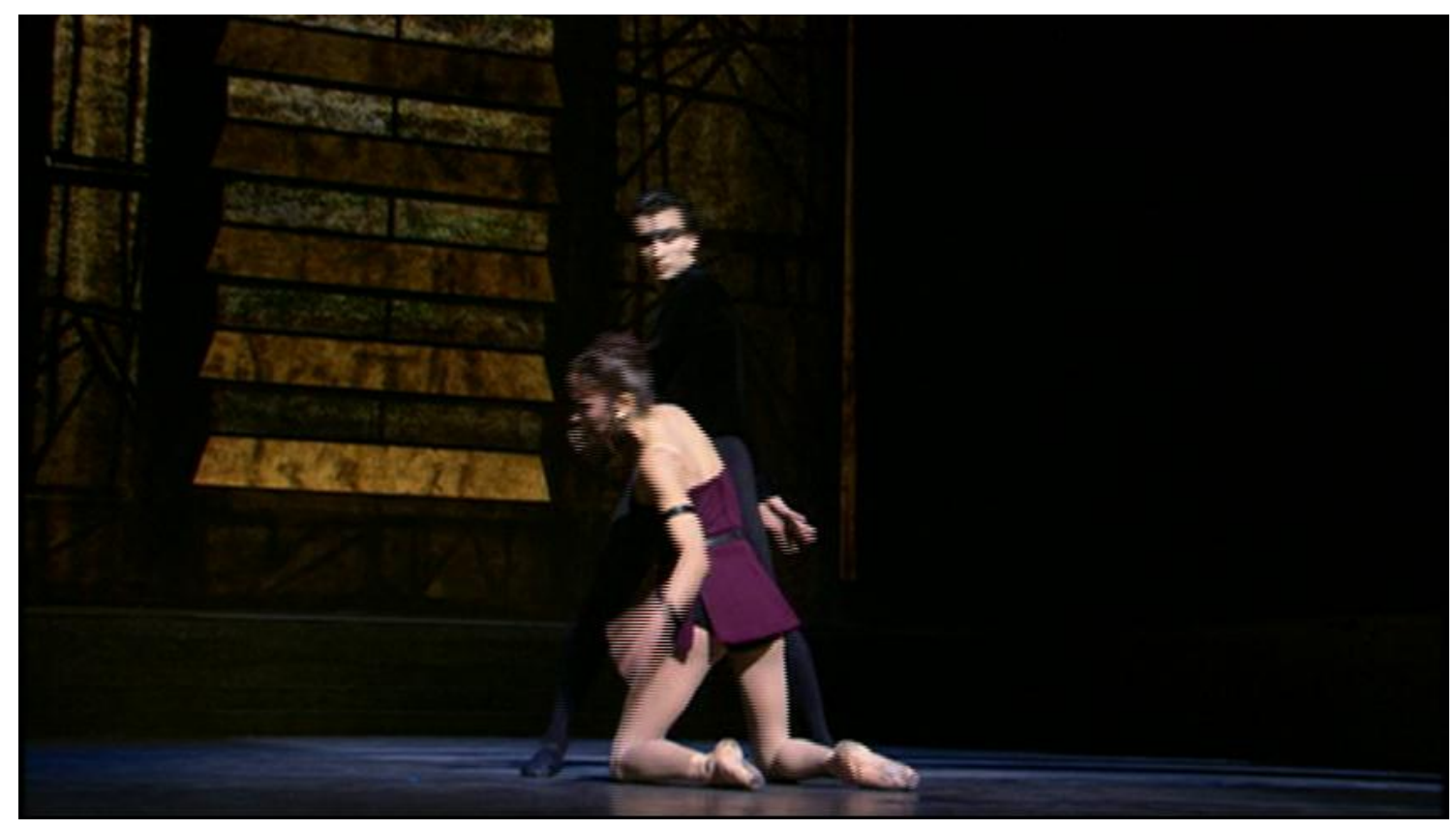

Figura 51 - Frollo esbofeteia Esmeralda, em Notre-Dame de Paris, 1996

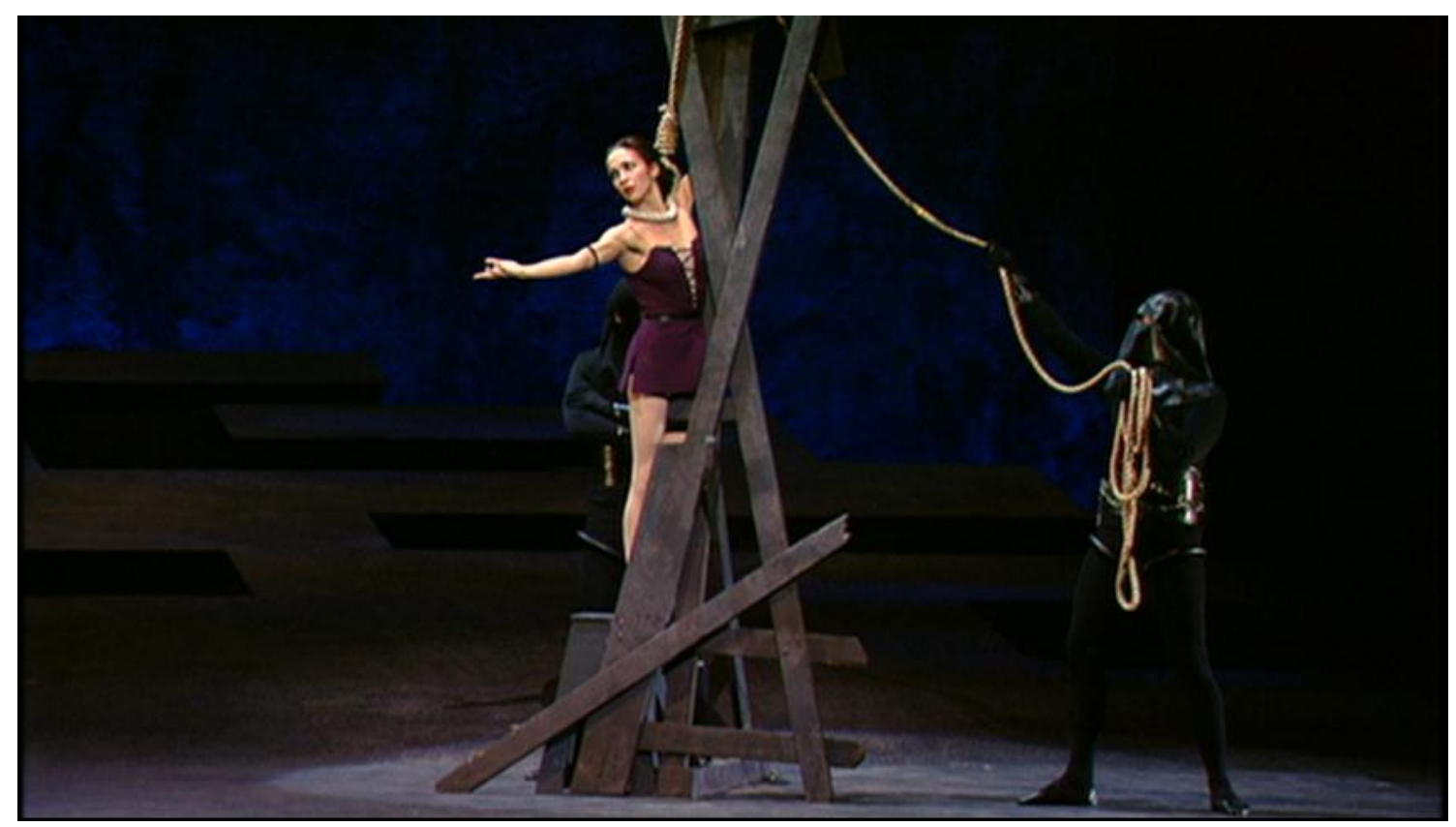

Figura 52 - A morte de Esmeralda, em Notre-Dame de Paris, 1996

Assim, Roland Petit consegue recriar, em sua narrativa coreográfica, a obsessão e a monstruosidade desse personagem hugoano. Da mesma forma que no romance, temos um personagem atormentado pela dupla impossibilidade de realização de sua paixão libidinosa: a proibição de seu ofício e a rejeição de Esmeralda, que prefere a morte à figura do padre. Tal inviabilidade conduz Frollo a atos extremos, os quais revelam a deformidade moral do personagem, ou seja, a sua monstruosidade. 


\subsection{Phœbus e Esmeralda: o amor carnal}

Na narrativa coreográfica, os laços que ligam Esmeralda a Phœbus são recriados de forma a destacar seu aspecto carnal. Ambos os personagens são dotados de sensualidade. Tal escolha do coreógrafo resgata o lado sedutor do belo capitão da obra literária.

Sabemos que, no romance de Victor Hugo, o encontro entre Esmeralda e Phœbus ocorre quando o capitão dos arqueiros salva a jovem cigana capturada por Quasimodo. Iludida pela premissa de que aquilo que é belo é bom, Esmeralda apaixonase à primeira vista pelo formoso arqueiro do rei. Todavia, Phœbus, noivo de Fleur-deLys e frequentador assíduo de cabarés, não alimenta mais do que um desejo carnal pela cigana. A fim de consumar sua concupiscência, ele mente para Esmeralda sobre sua situação e seus sentimentos, prometendo casar-se com ela. Perdidamente apaixonada e ludibriada com o juramento de Phœbus, Esmeralda dirige-se até uma mal afamada taverna, onde se entrega a seu amado.

Por sua vez, a personagem feminina de Roland Petit apresenta-se como uma mulher menos inocente e mais segura de si. Desde sua primeira aparição em cena, durante seu solo, Esmeralda esboça sua profunda sensualidade. Todavia, podemos percebê-la de modo mais claro em sua dança, no momento de seu encontro com Phœbus. Ao avistá-lo, ela corre para seus braços e dois se beijam quase que instantaneamente, ação totalmente diferente da do romance, uma vez que, ao ser salva por Phœbus, Esmeralda evade-se o mais rápido possível.

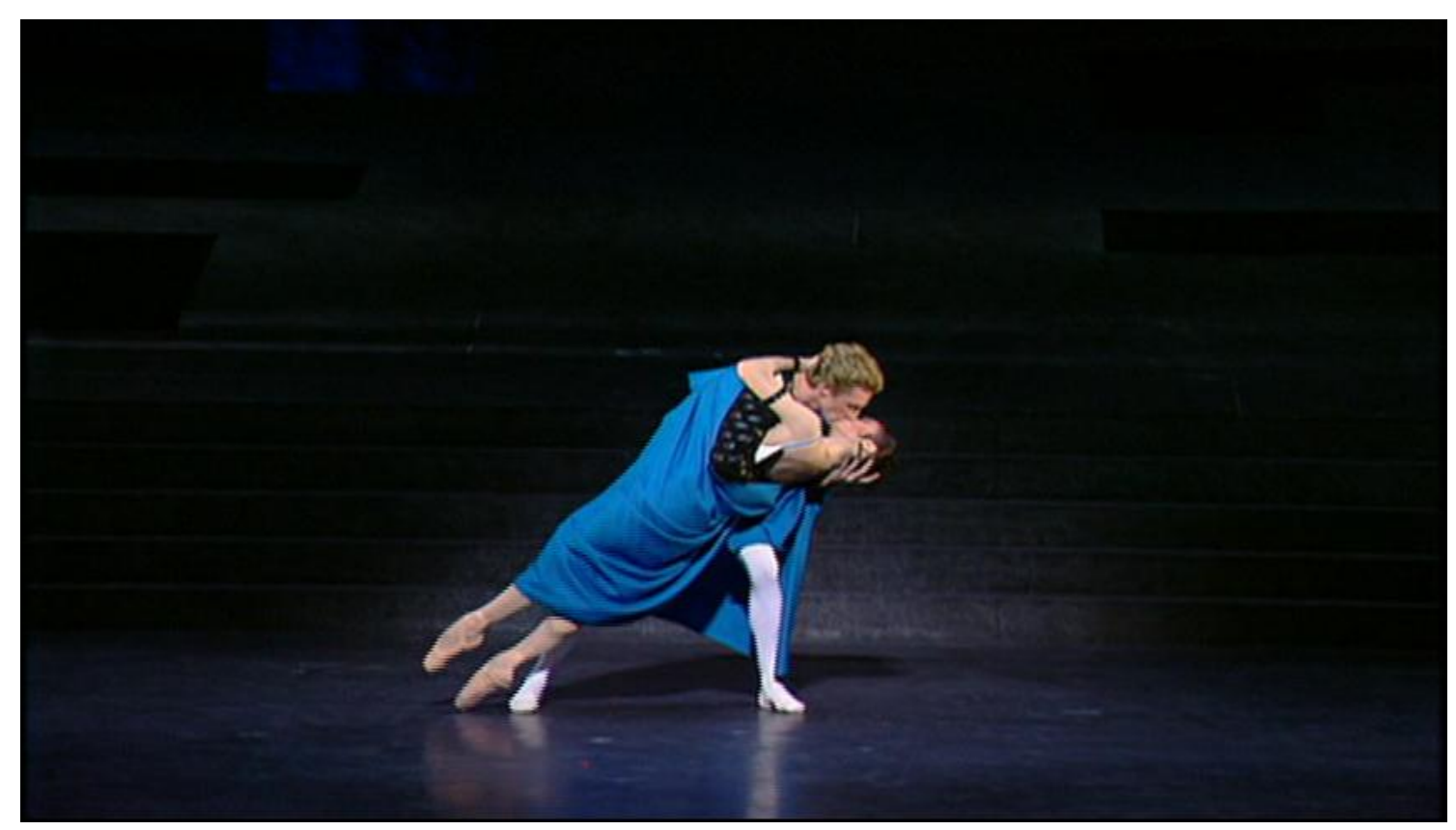


Por outro lado, o personagem de Phœbus é concebido de forma semelhante ao da obra literária. Seu caráter sedutor e seu gosto pelos prazeres carnais são ressaltados por Roland Petit, especialmente na releitura da cena da taverna. Esta sequência, além de extremamente importante para o desfecho da narrativa, permite que o público apreenda a faceta erótica desse personagem assim como a relação que cultiva com Esmeralda.

Das “cem figuras confusas", " do barulho dos copos, das pessoas comendo, dos juramentos e das confusões", que animavam o cabaré "Maça de Eva", Roland Petit conserva apenas as meretrizes que trabalhavam nesse lugar. A fim de recriar o ambiente grotesco descrito na narrativa, o coreógrafo traz para a cena mulheres de formas desproporcionais, com atributos físicos femininos exagerados. $\mathrm{O}$ excesso do figurino aliado à gestualidade realizada pelas bailarinas, a qual é basicamente composta de agachamentos, movimentos de quadris e movimentos bruscos de ombros, são responsáveis por atribuir a Phœbus sua dimensão vulgar.

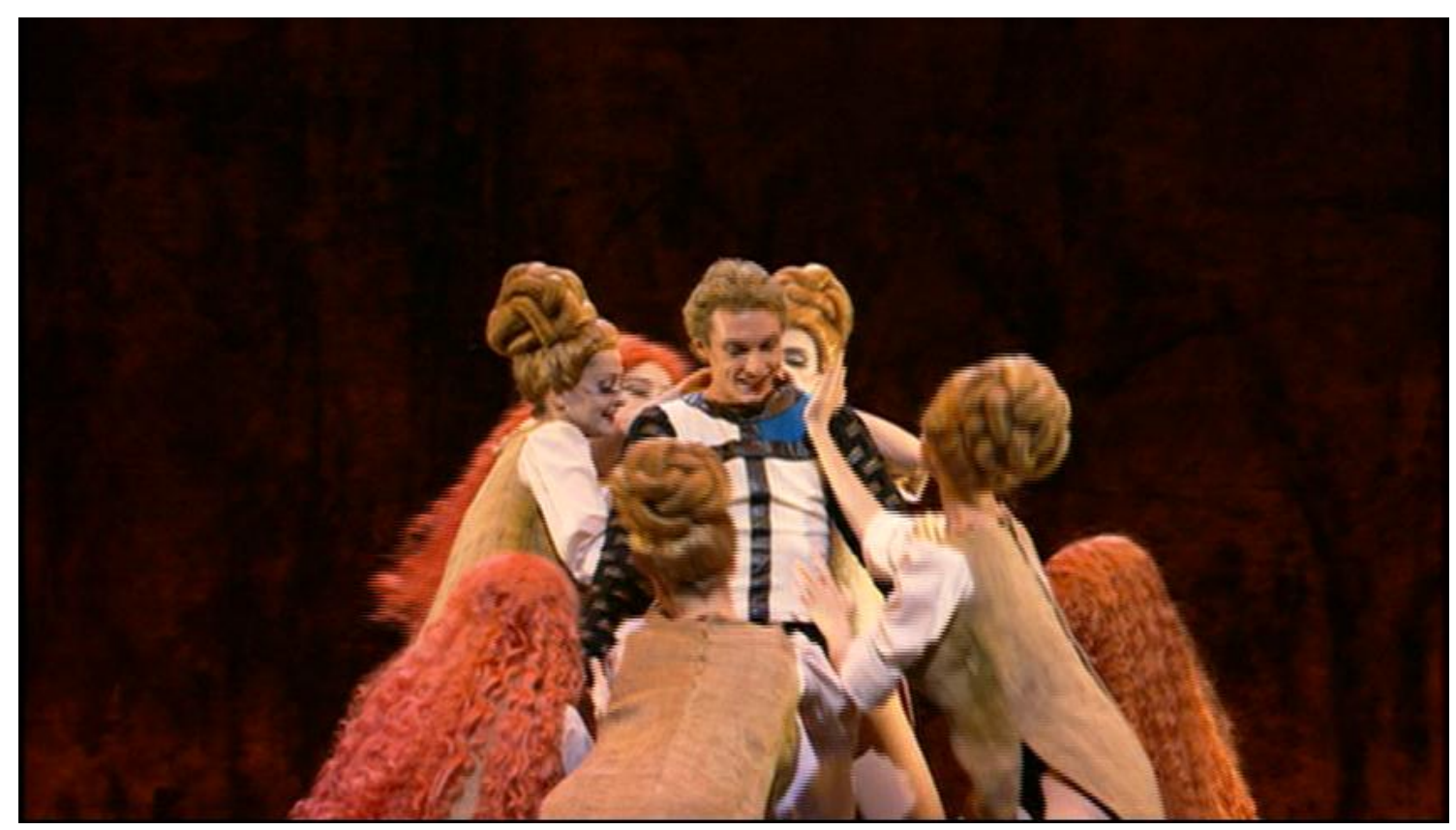

Figura 54 - Phøebus em meio as prostitutas, em Notre-Dame de Paris, 1996

A forma como as bailarinas contracenam com o personagem, cercando-o, cobrindo-o de carícias e, por fim, arrancando sua roupa revelam a familiaridade de Phœbus com aquele ambiente, assim como seu gosto pela luxúria. Elas o veneram, enquanto que o capitão olha com malícia para os seus corpos. De fato, durante essa sequência, os bailarinos praticamente não dançam, quase não há coreografia. Toda a movimentação baseia-se em um jogo de cena, em que a pantomina prevalece de forma a trazer um realismo para a cena. 
Esmeralda, por sua vez, permanece no canto do palco, apenas observando. Ela não interage com os demais personagens. A escolha de deixar a bailarina em cena nesse momento contribui, mais uma vez, para a construção dessa personagem que não nos parece tão inocente quanto à da narrativa textual, a qual se dirige até a taverna para declarar seu amor ao capitão. Ela observa a interação de Phœbus com as outras mulheres e, mesmo assim, deixa-se envolver por ele. Efetivamente, a sensualidade de Phœbus e a sua habilidade em seduzir outras mulheres parecem atrair ainda mais a atenção de Esmeralda que, em seguida, entrega-se ao belo capitão.

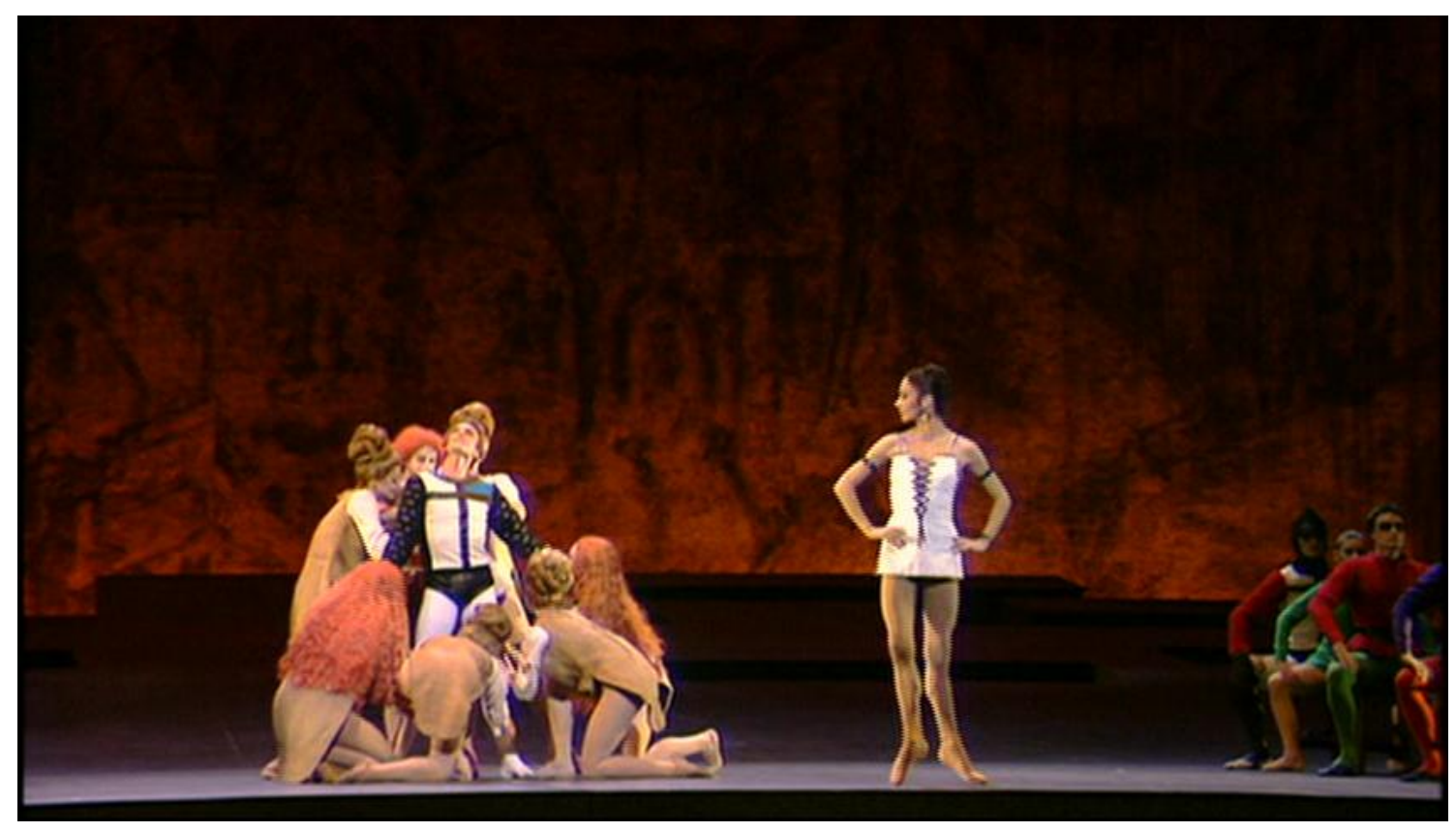

Figura 55 - Esmeralda observa Phœbus, em Notre-Dame de Paris, 1996

Nesse momento, o corpo de baile retira-se do palco, deixando os amantes a sós. Mais uma vez, há a ausência de movimentos e a pantomina prevalece. Os dois se beijam, trocam carícias e abraços. Nesse instante, o texto hugoano transparece através da dança, a qual recria gesto a gesto a narrativa. $O$ ápice dessa sequência ocorre justamente quando Phœbus despe brutalmente Esmeralda.

"Com um gesto rápido, Phœbus tirou a vestimenta da Egípicia. A pobre criança que permanecera pálida e sonhadora até então, despertou-se de sobressalto. Ela afastou-se do atrevido oficial, lançando um olhar sob seus ombros e pescoço nus. [...] ela cruzou seus dois braços sob o seus seios para escondê-los."

${ }^{128}$ HUGO, 2009, p. 369 
No entanto, diferentemente do romance, Esmeralda entrega-se ao desejo, não demonstrando pudor ou medo em relação a Phœbus. Ao contrário, a personagem revelase uma mulher segura de si, atrevida e audaciosa, capaz das mais diversas ações para a realização de sua paixão.
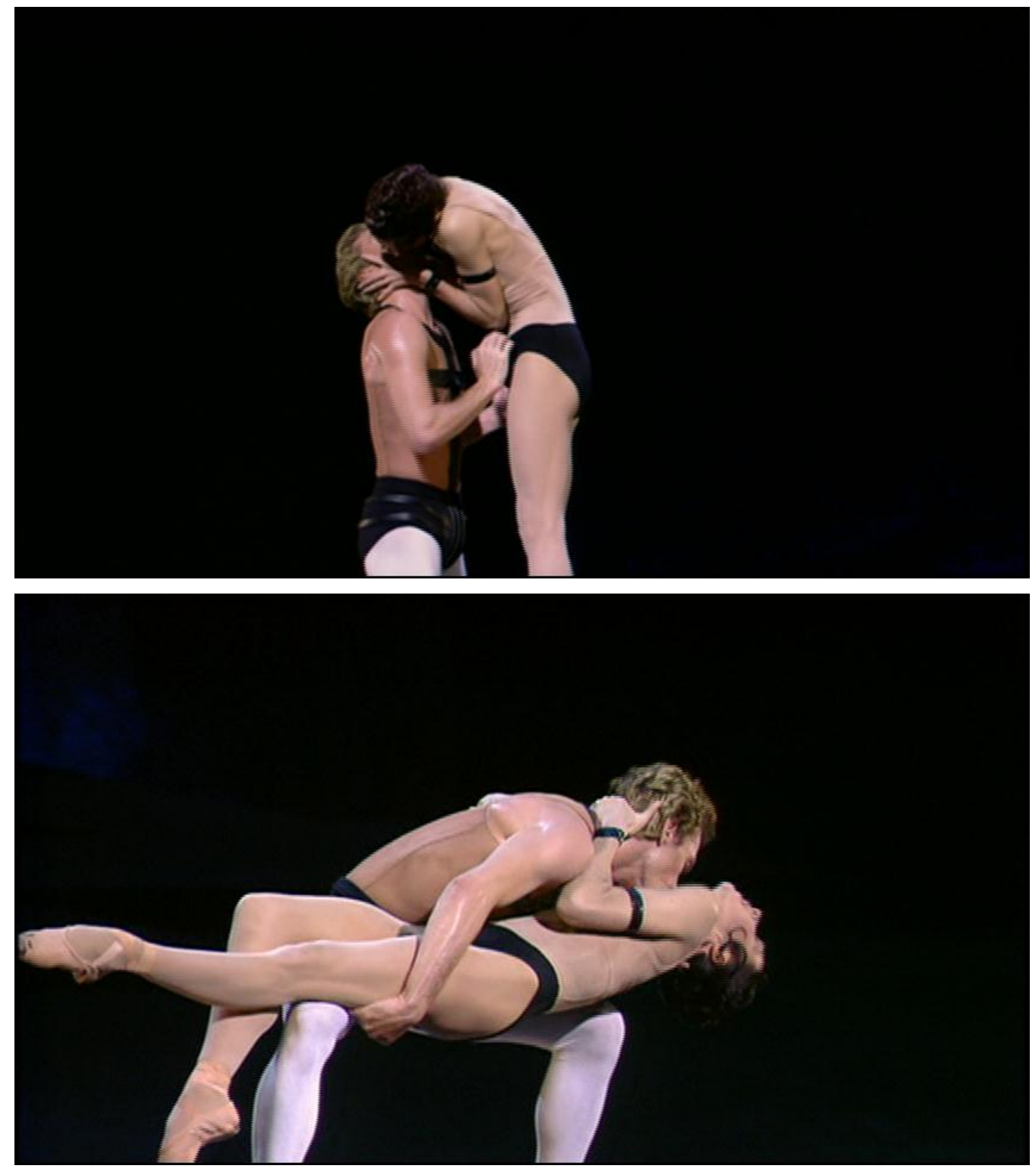

Figuras 56 e 57 - Esmeralda e Phœbus, em Notre-Dame de Paris, 1996

Logo, a sequência da taverna assim como o duo entre Esmeralda e Phœbus consegue traduzir gestualmente a paixão que une esses dois personagens, todavia a narrativa coreográfica agrega valores tanto na construção da personalidade de ambos quanto na escrita dos sentimentos que os une. 
Procuramos, neste trabalho, elucidar as possíveis relações estabelecidas entre a dança e a literatura que, embora se configurem como objetos estéticos distintos, possuem uma mesma natureza, posto que ambos podem ser entendidos como textos narrativos.

Neste percurso buscamos identificar e analisar as principais dinâmicas envolvidas no processo de metamorfose da palavra escrita em movimento e som, principalmente no que concerne a transposição das relações de amor e monstruosidade desenvolvidas entre os personagens do romance Notre-Dame de Paris, de Victor Hugo, para o balé homônimo, de Roland Petit.

Após identificarmos os diferentes tipos de vínculos afetivos empreendidos entre os personagens e sua relação com a monstruosidade em ambas as narrativas, foi possível empreender uma vasta prospecção e tecer importantes considerações a respeito de seu processo de transposição do romance para a dança.

Ao recriar Notre-Dame de Paris, Roland Petit concentrou sua narrativa na faceta trágica da obra hugoana, que, por sua vez, anuncia desde as primeiras páginas o seu mote ananké $e^{129}$ Ele recria por meio da linguagem coreográfica, as relações que unem o destino fatal da jovem Esmeralda aos dos personagens masculinos de Claude Frollo, Quasimodo e Phœbus. A fim de lograr esse empreendimento, Petit buscou na obra literária a significação profunda do movimento, transformando a emoção da narrativa em poesia gestual ao ritmo da música de Maurice Jarre, executada pelos movimentos bailarinos da Ópera de Paris, caracterizados por Yves Saint Laurent, em meio aos cenários de René Allio e à iluminação imaginada por Jean-Michel Désiré. Assim, Petit foi capaz de orquestrar o espetáculo e de sintetizar em seus personagens e na sua gestualidade uma linguagem sem palavras, a qual buscou desenvolver as diversas nuances do texto, explorando as metáforas da escritura, as imagens depreendidas do texto e a escrita filosófica e política de Victor Hugo.

\footnotetext{
${ }^{129}$ De acordo com SEEBACHER apud BARRETO (2006, p. 302) a palavra ANÁГKH "significa simplesmente fatalidade, se que seja o fatum latino". Conforme explica, foi encontrada, no dossiê de notas de Victor, uma página de dicionário com a seguinte definição: necessidade , coerção - lei fatal, obrigação imperiosa - destino, morte, calamidade - por vezes razão convincente, argumento decisivo e sem réplica - outras vezes, principalmente no plural, suplício, tortura - outras vezes relação íntimo ligação de parentesco.
} 
Mestre na arte da linguagem narrativa coreográfica, Roland Petit concebeu Notre-Dame de Paris como uma obra sincrética na qual elementos como os gestos produzidos pelos bailarinos, a música, o figurino, o cenário e a iluminação compõem, de acordo com Mariana Trotta, um todo de sentido. Assim, por meio das diferentes escrituras realizadas por Jarre, Saint Laurent, Allio, Désiré e os diferentes bailarinos e dançarinos, Roland Petit orquestra um espetáculo sobre amor e morte, marcado por constantes tensões e ambiguidades entre todas as linguagens, as quais compõem uma obra única, quase inclassificável quanto ao gênero e a escola que segue.

Sua narrativa estrutura-se em torno das relações de amor e paixão estabelecidas entre os personagens, assim como em seus efeitos e suas consequências. Cada personagem masculino mantém com Esmeralda uma relação de natureza amorosa, as quais variam de intensidades, transmutando do amor puro e sublime à paixão perversa e destruidora. Tais nuances de afetos transfiguram-se em coreografia, gestos e música.

No balé, Quasimodo e Esmeralda são concebidos como personagens fisicamente antitéticos. Enquanto Quasimodo se apresenta como um ser disforme, Esmeralda encarna o ideal da beleza. Da mesma forma que no romance hugoano, o Quasimodo da narrativa coreográfica nutre um amor incondicional por Esmeralda que, por sua vez, não o corresponde, cultivando apenas um sentimento de compaixão e amizade pelo sineiro. A oposição entre esses personagens é construída na dança a partir do emprego de elementos contrastantes como a música, o figurino e a movimentação oposta. Assim, Esmeralda executa movimentos longilíneos e graciosos, respeitando a gramática clássica, ao passo que Quasimodo realiza movimentos quebrados, valorizando a parte baixa do palco e enfatizando sua condição física. No entanto, embora díspares, esses personagens apresentam uma complementariedade em suas gestualidades, atendendo o princípio hugoano de harmonia dos contrários, exposto no Prefácio de Cromwell. Logo, essa complementariedade de seus movimentos poderia ser entendida como a transfiguração metafórica dos laços que unem esses personagens marginalizados e rejeitados pela a sociedade.

Por sua vez, o padre Claude Frollo tem suas convicções abaladas e sua alma atormentada pelo desejo incontrolável que nutre por Esmeralda. A impossibilidade de realização dessa paixão, devido aos votos sacerdotais e aliada ao sofrimento pela rejeição de Esmeralda, desperta em Frollo uma potência negativa, a qual se traduz em uma série de atos criminosos contra a jovem cigana. Esses atos extremos cometidos 
contra Esmeralda, os quais culminam na morte da personagem, revelam a deformidade de caráter do clérigo, ou seja, a sua monstruosidade moral. Tal monstruosidade é concebida pelas diferentes escrituras sígnicas que compõe o balé e que criam um Claude Frollo sombrio e austero, atordoado pelo som incessante do tamborim de Esmeralda. Logo, é possível pensar que a concepção coreográfica do personagem teria se inspirado no que há de mais violento no romance hugoano, a fim de traduzir para a dança a perversidade e a deformidade moral de Claude Frollo.

Resta ainda no balé de Roland Petit, a representação do desejo carnal e passageiro que Phœbus sente por Esmeralda. Servindo-se dos diversos elementos que compõe a dança, Petit recria o capitão da narrativa hugoana de forma a ressaltar sua faceta sedutora, evidenciando, principalmente, sua beleza física e o seu gosto pelos prazeres carnais. Por sua vez, a Esmeralda da narrativa coreográfica revela-se como uma mulher mais segura de si e audaciosa, capaz das mais diversas ações para a concretização de sua paixão por Phœbus.

Além de agregar valores para a construção desses personagens, Roland Petit promove outra mudança importante em relação à obra à narrativa textual: o desfecho da trama transcorre de modo diferente. Golpeado por Frollo com um punhal, Phœbus morre, enquanto que no romance seu destino trágico se resume a seu casamento com Fleur-de-Lys. Por outro lado, o personagem de Quasimodo, encontrado morto abraçado à Esmeralda anos depois, não morre na narrativa coreográfica. Ele apenas sai de cena carregando em seus braços o corpo desfalecido da bela cigana. De fato, ele é o único personagem que sobrevive ao final do balé. Logo, é possível compreender a razão pela qual Roland Petit classifica sua narrativa como uma história de amor e de morte".

A análise dessas relações de amor e monstruosidade estabelecidas no balé NotreDame de Paris nos permite observar que a recriação de uma obra literária para a dança não se trata de uma simples tradução de um código para o outro. Ao contrário, a transformação da palavra escrita em movimentos produz suas próprias metáforas, agregando valores e sentidos ao texto de origem, ou ainda, de acordo com Benjamin, dando-lhe uma sobrevida. O conjunto de escrituras que compõe o balé não apenas nos abre outras perspectivas para além do texto romanesco, como proporcionam novas possibilidades de leitura do romance, as quais asseguram a propagação e a posteridade da obra de Victor Hugo. Assim, ao transpor Notre-Dame de Paris para a dança, Roland Petit não somente recria os célebres personagens da narrativas literária; como cria, 
dentro do campo da dança, novos mitos, com existências próprias, os quais passam, por sua vez, a fazer parte do repertório de personagens clássicos da dança.

Sabemos que esta pesquisa se configura apenas como um estudo inicial da relação do romance Notre-Dame de Paris e a dança. Restar-nos-á ainda, entretanto, investigarmos em pesquisas vindouras como outro aspectos do texto hugoano são recriados no espetáculo de Petit, ou ainda, refletirmos sobre as questões próprias referentes à análise de um balé através de um registro fílmico. 
ACAPOVI, Crépin. L'Être et l'amour: une étude de l'ontologie de l'amour chez Paul Tillich. Berlim : 2010.

BALADIER, Charles; David-Menard Monique; Iogna-Prat Dominique ; Lucken Christopher. L'amour au Moyen Âge. Autour du livre de Charles Baladier, Érôs au Moyen Âge. Amour, désir et «delectatio morosa». In: Médiévales. Vol. 40. Paris : Rome des jubilés, 2001.

BARRETO, Junia R. de Faria. Figures de monstres dans l'œuvre théâtrale et romanesque de Victor Hugo. Lille: ANRT, 2008

COHEN, Jeffrey Jerome. A cultura dos monstros: sete teses. In: Pedagogia dos monstros. Os prazeres e os perigos da confusão de fronteiras. Belo Horizonte: Autêntica, 2000.

CHEVALIER, Jean; GHEERBRANT, Alain. Dicionário de símbolos: mitos, sonhos, costumes, gestos, formas, figuras, cores, números. Rio de Janeiro: José Olympio, 2006.

CHIRESCU, Anna. Deux adaptations chorégrafiques de Notre-Dame de Paris de Victor Hugo :étude comparative des ballets de Jules Perrot et La Esmeralda et de Roland Petit Notre-Dame de Paris. 2009. 110 f. Dissertação (Mestrado em Literatura e Linguística francesas e latinas)- Université Paris III. Sorbonne Nouvelle, Paris.

DESCARTES, René. As Paixões da Alma. São Paulo: Abril Cultural, 1979.

FOUCAULT, Michel. Os anormais. São Paulo: Martins Fontes, 2013.

FIETTE, Alexandre. Un patrimoine pour la danse. Roland Petit à l'Opéra de Paris.Paris :Opéra National de Paris, 2007.

GARAUDY, Roger. Dançar a vida. Rio de Janeiro: Nova Fronteira, 1980.

GIL, José. Monstros. Lisboa: Relógio d’Água Editores, 2006.

GLON, Marie; LAUNAY, Isabelle. Histoire des gestes. Paris : Actes Sud, 2012.

HUGO, Victor. O Corcunda de Notre Dame. São Paulo: Editora Edigraf, 1958.

Notre-Dame de Paris. Paris : Gallimard, Folio Classique, 2002.

KAPPLER, Claude. Monstros, demônios e encantamentos no fim da Idade Média. São Paulo: Martins Fontes, 1994.

LAROCHE, Chantal. De la littérature à la danse, Notre-Dame de Paris : transcription sémiotique de l'écriture romanesque en écriture chorégraphique : le roman de Victor Hugo Notre-Dame de Paris et les ballets La Esmeralda de Jules Perrot 
au XIXe siècle et Notre-Dame de Paris de Roland Petit au XXe siècle. 1993. 436 f. Tese (Doutorado em História da Arte) - Université Paris 1.Sorbonne, Paris.

PASTORI, Jean-Pierre. Roland Petit Rythme de vie. Entretiens avec Jean- Pierre Pastori. Paris : Paroles vives, 2003.

SIMÕES, Cibele. A luz da linguagem. A iluminação cênica: de instrumento de visibilidade à 'scriptura do visível'. 2013. 375 f. Tese. (Doutorado em artes Cênicas) Escola de Comunicação. USP, São Paulo.

TROTTA, Mariana. A dança-espetáculo: uma análise semiótica. 2010. 199 f. Tese (Doutorado em Estudos da Linguagem). UFF, Niterói.

\section{Referências eletrônicas}

TAPIÉ, Marie. Les adaptations cinématographiques de Notre-Dame de Paris de Victor Hugo. Étude comparée du roman et des adaptations de Wallace Worsley (1923), William Dieterle (1939), Jean Delannoy (1956), Michael Tuchner (1982), Gary Trousdale et Kirk Wise (1996) et Peter Medak). Disponível em: <http://groupugo.div.jussieu.fr/Default_Etudes.htm>.Acessado em 20 de julho de 2015.

SEEBACHER, Jacques. Le système du vide dans Notre-Dame de Paris. Disponível em : $</$ web/revues/home/prescript/article/litt_0047-4800_1972_num_5_1_1946>.

Acessado em 7 de junho de 2015.

VIGNEST, Romain. La danse d'Esmeralda ou le roman dramatique . Lecture d'un passage représentatif de l'esthétique romanesque de V. Hugo. Disponível em: $<$ http://www.aplettres.org/Esmeralda.htm>.Acessado em 11 de junho de 2015

\section{Vídeo}

NOTRE-DAME de Paris.Direção: André Fédérick. Produção: Ópera National Paris e Telmondis. Paris: 1996, 1DVD, 86 min. 
I. Croquis dos figurinos de Notre-Dame de Paris, por Yves Saint Laurent 


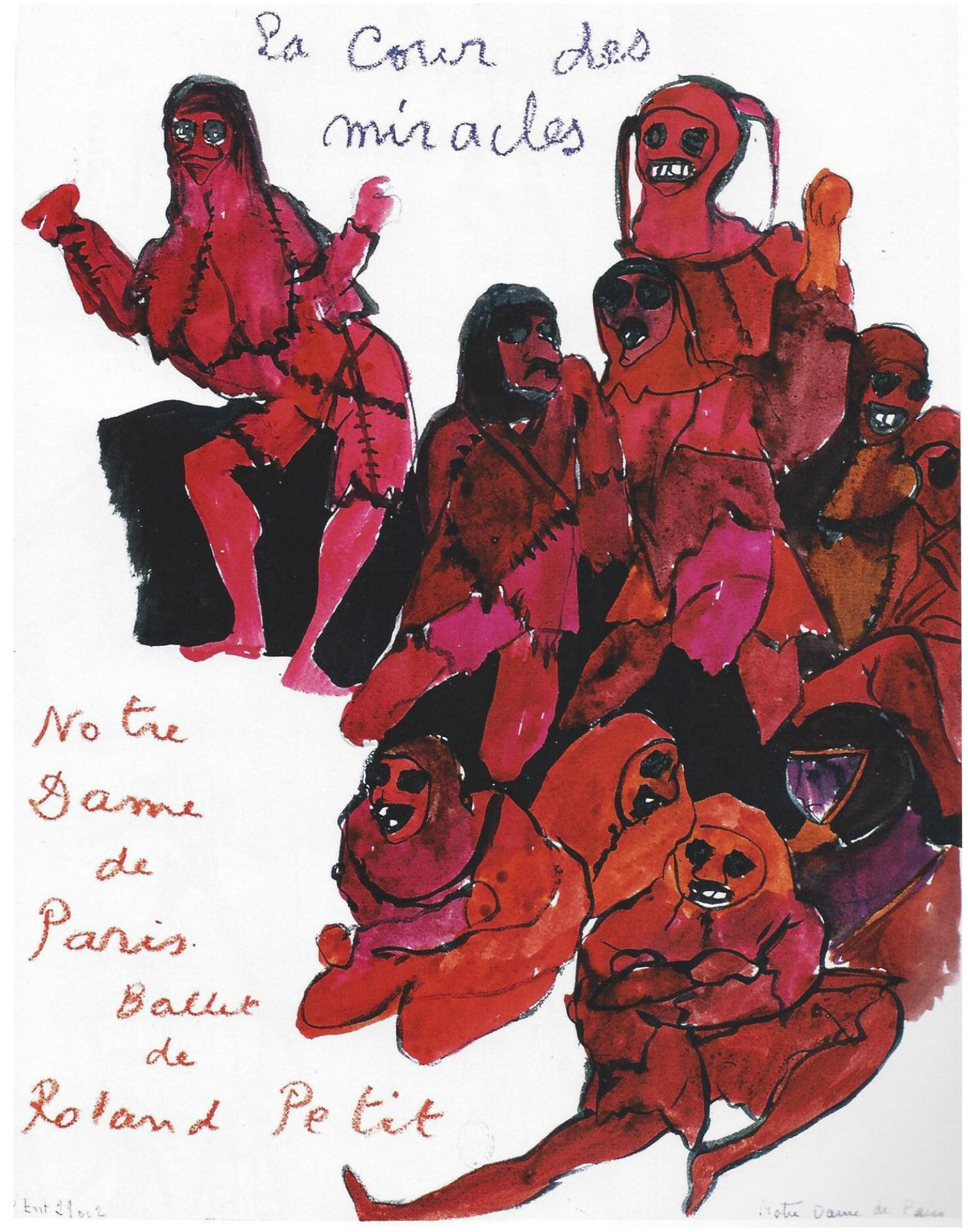

Figura 58 - SAINT LAURENT, Yves. La Cour de Miracles. (O pátio dos milagres). Giz e tinta sobre o papel, 49,5 x 39,5 cm. Fonte: FIETTE. 2007, 87 


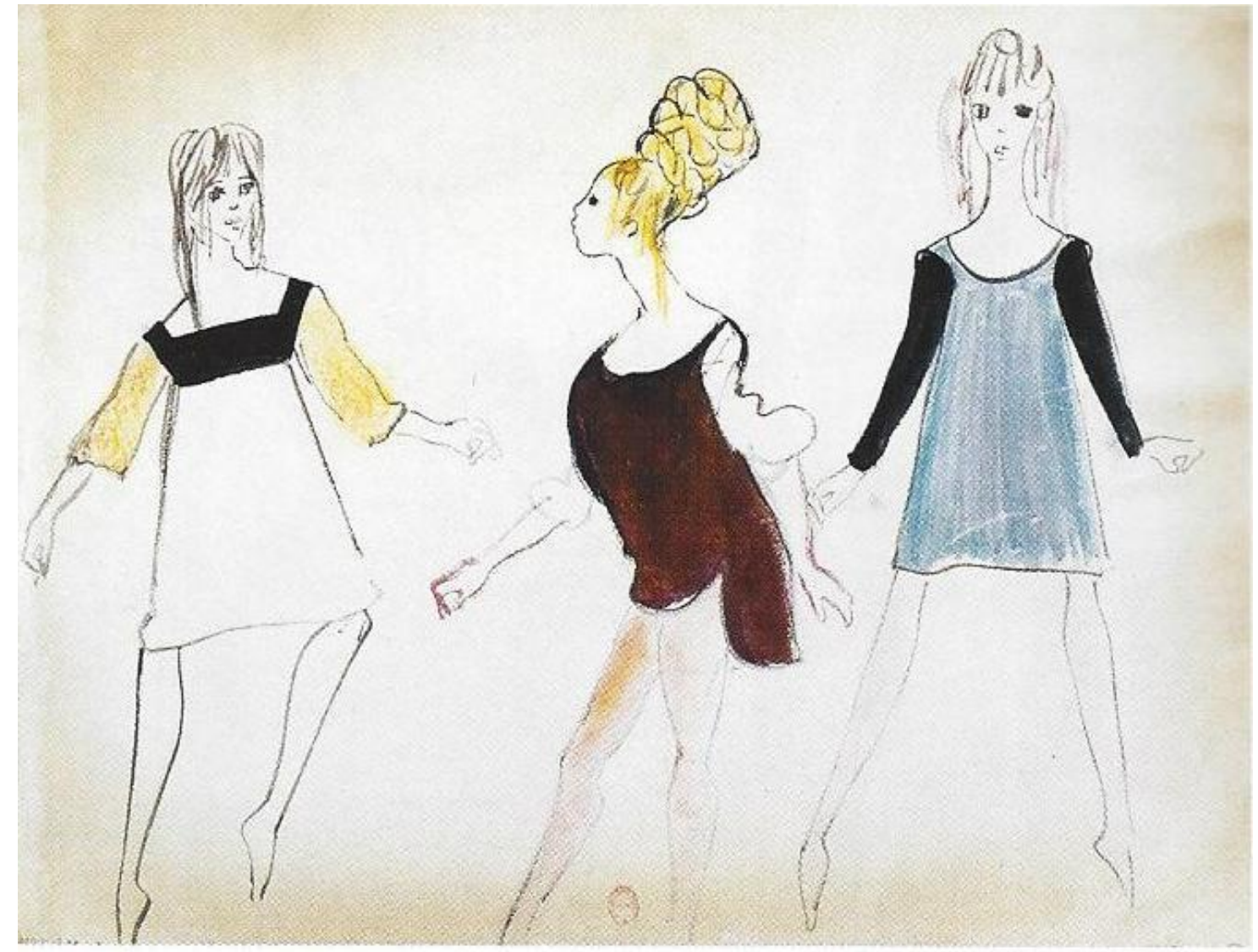

Figura 59 - SAINT LAURENT, Yves. . [S/n]. Giz, tinta e guache sobre o papel, 49 x $65 \mathrm{~cm}$. Fonte:

FIETTE. 2007, 90 


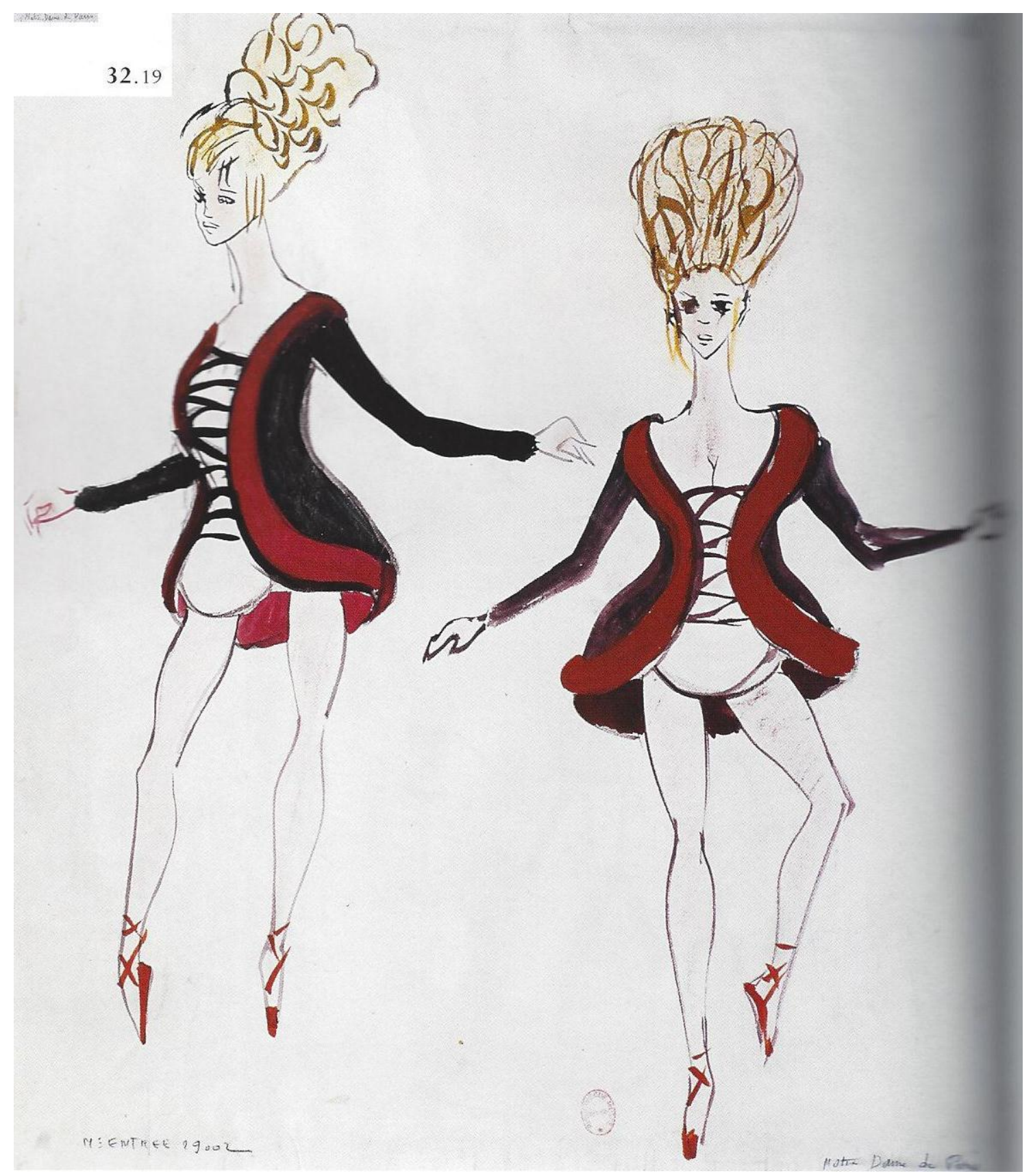

Figura 60 - SAINT LAURENT, Yves. . [S/n]. Giz, tinta e guache sobre o papel, 50 x $43 \mathrm{~cm}$. Fonte: FIETTE. 2007, 90 


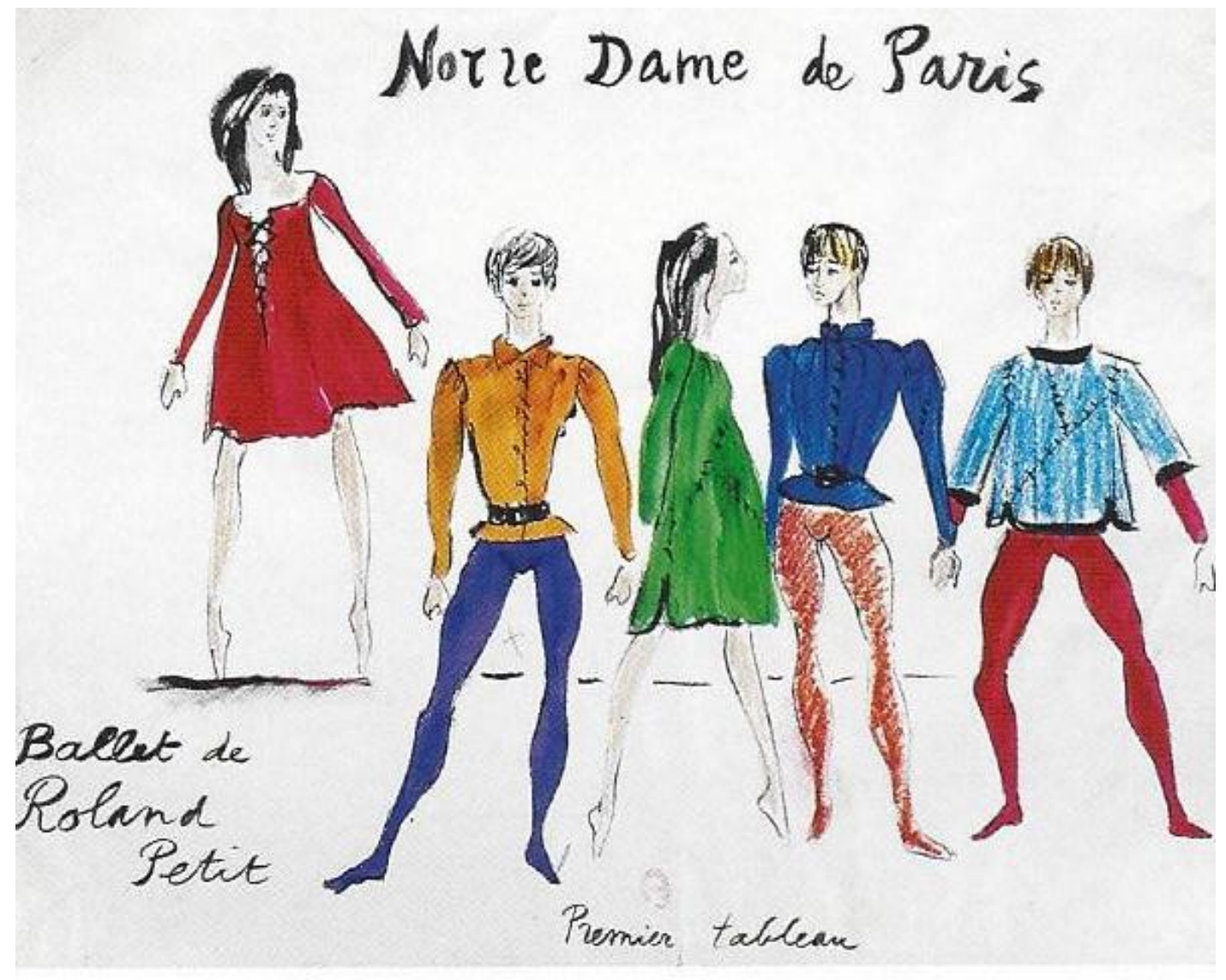

Figura 61 - SAINT LAURENT, Yves. . Premier tableau (Primeiro quadro). Giz, tinta e guache sobre o papel, 50 x $43 \mathrm{~cm}$. Fonte: FIETTE. 2007, 91 


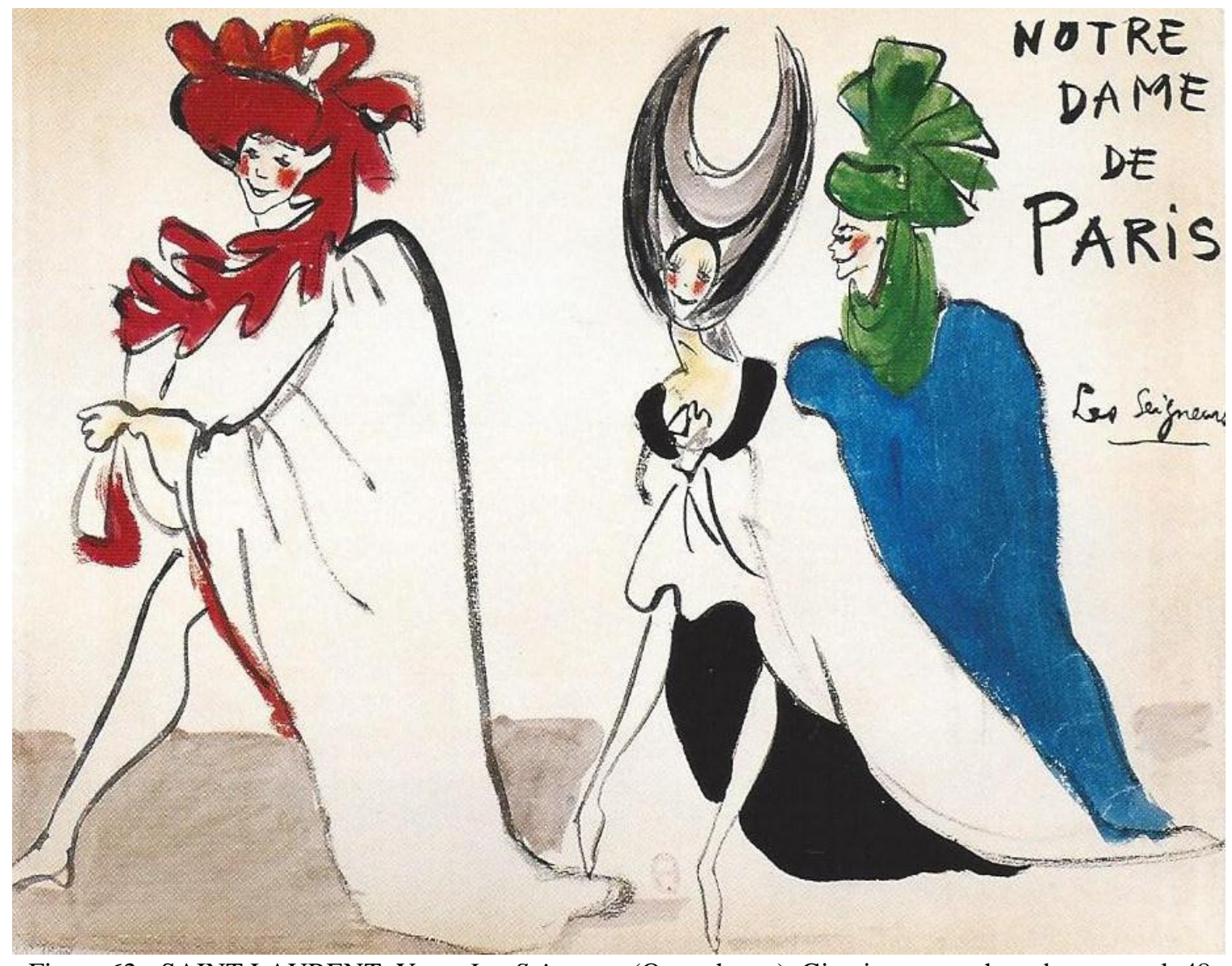

Figura 62 - SAINT LAURENT, Yves. Les Seigneurs (Os senhores). Giz, tinta e guache sobre o papel, 48 x 64 cm. Fonte: FIETTE. 2007, 91 


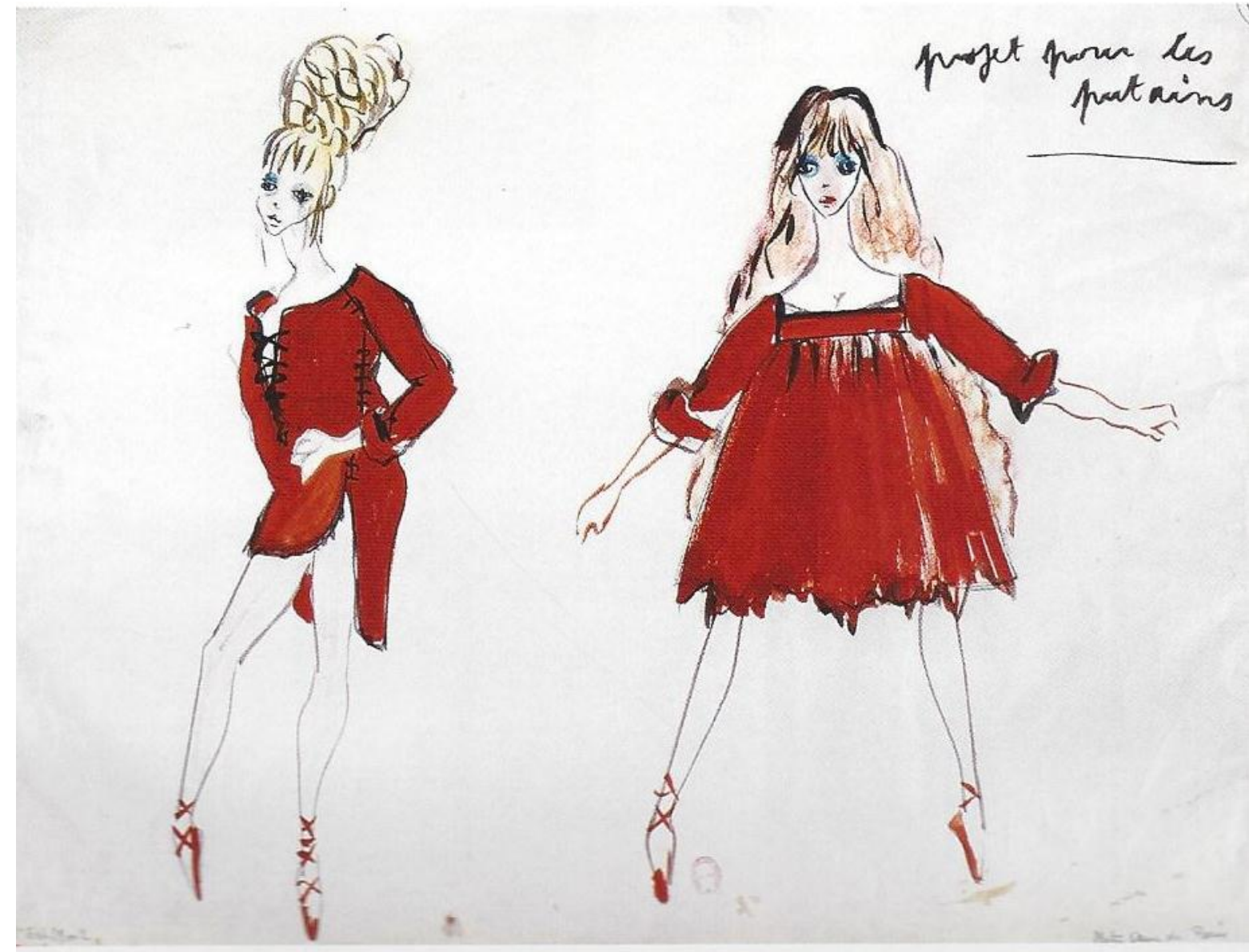

Figura 63 - SAINT LAURENT, Yves. . Projet pour les putains (Projeto para as prostitutas). Giz, tinta e guache sobre o papel, 50 x 64,5 cm. Fonte: FIETTE. 2007, 91 


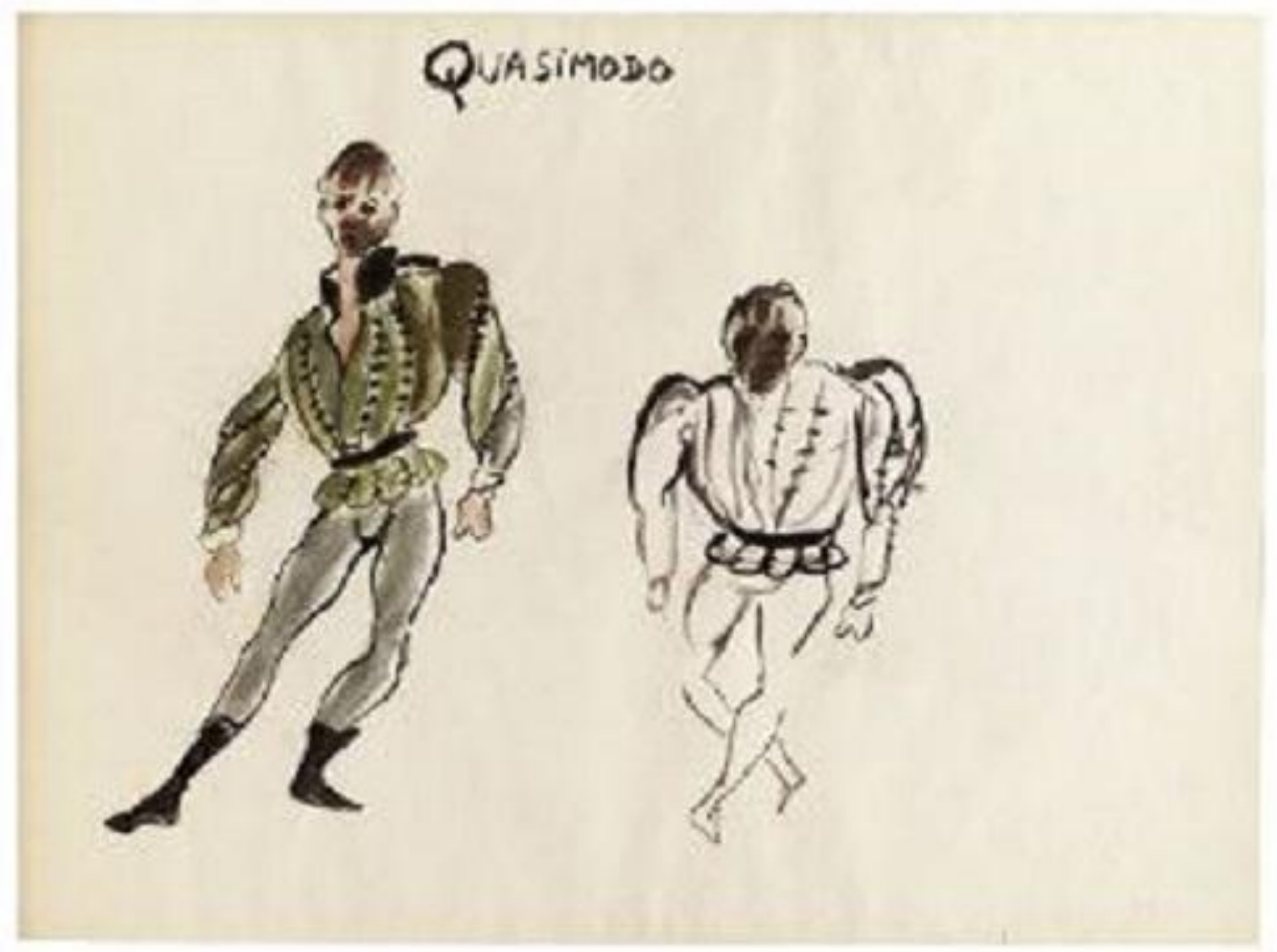

Figura 64 - SAINT LAURENT, Yves. . Quasimodo. Giz e tinta sobre o papel, 32 x 39,5 cm. Fonte: FIETTE. 2007, 89. 


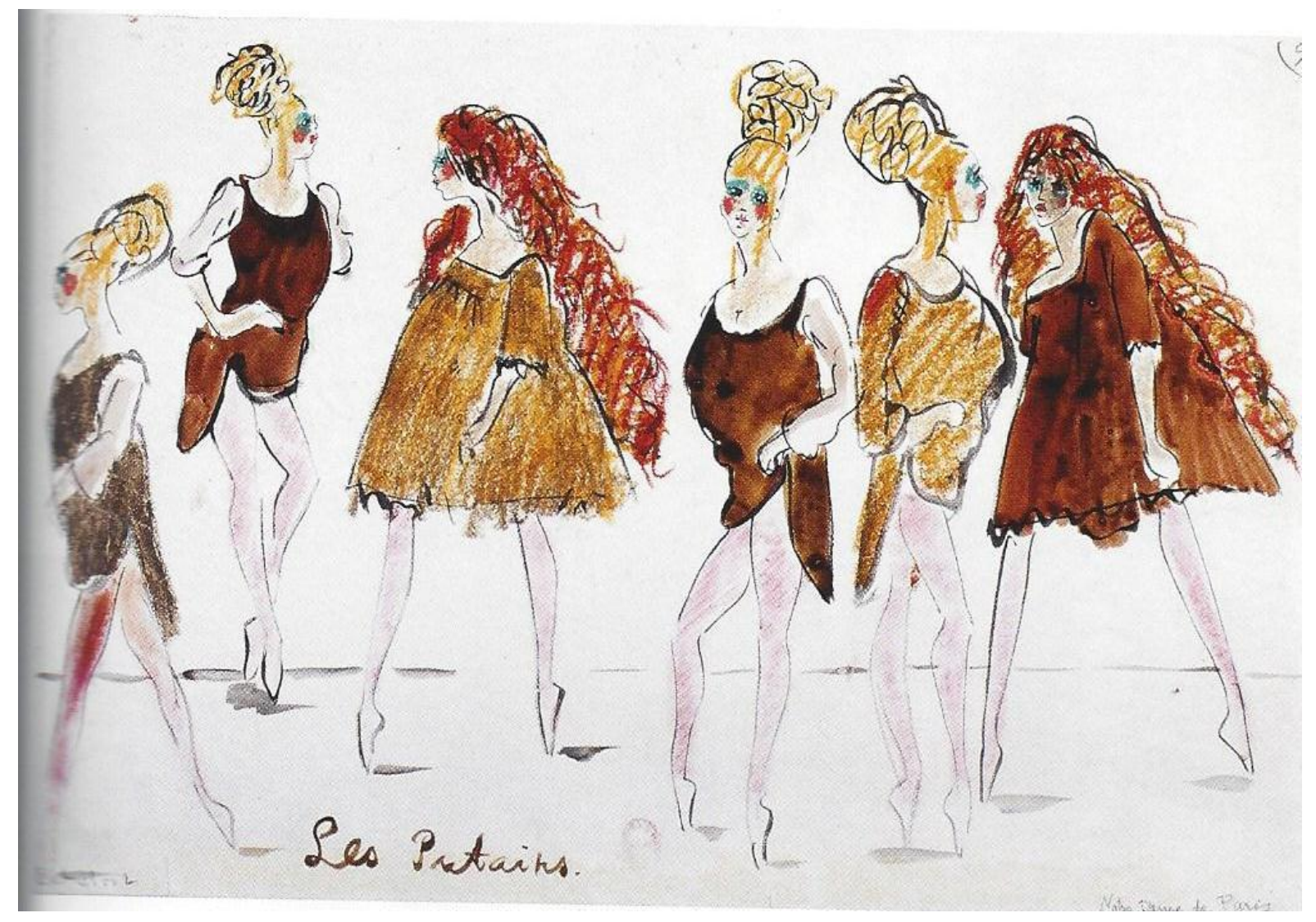

Figura 65 - SAINT LAURENT, Yves. . Les Putains (As prostitutas). Giz, tinta e guache sobre o papel, 32,3 x 50 cm. Fonte: FIETTE. 2007, 89. 


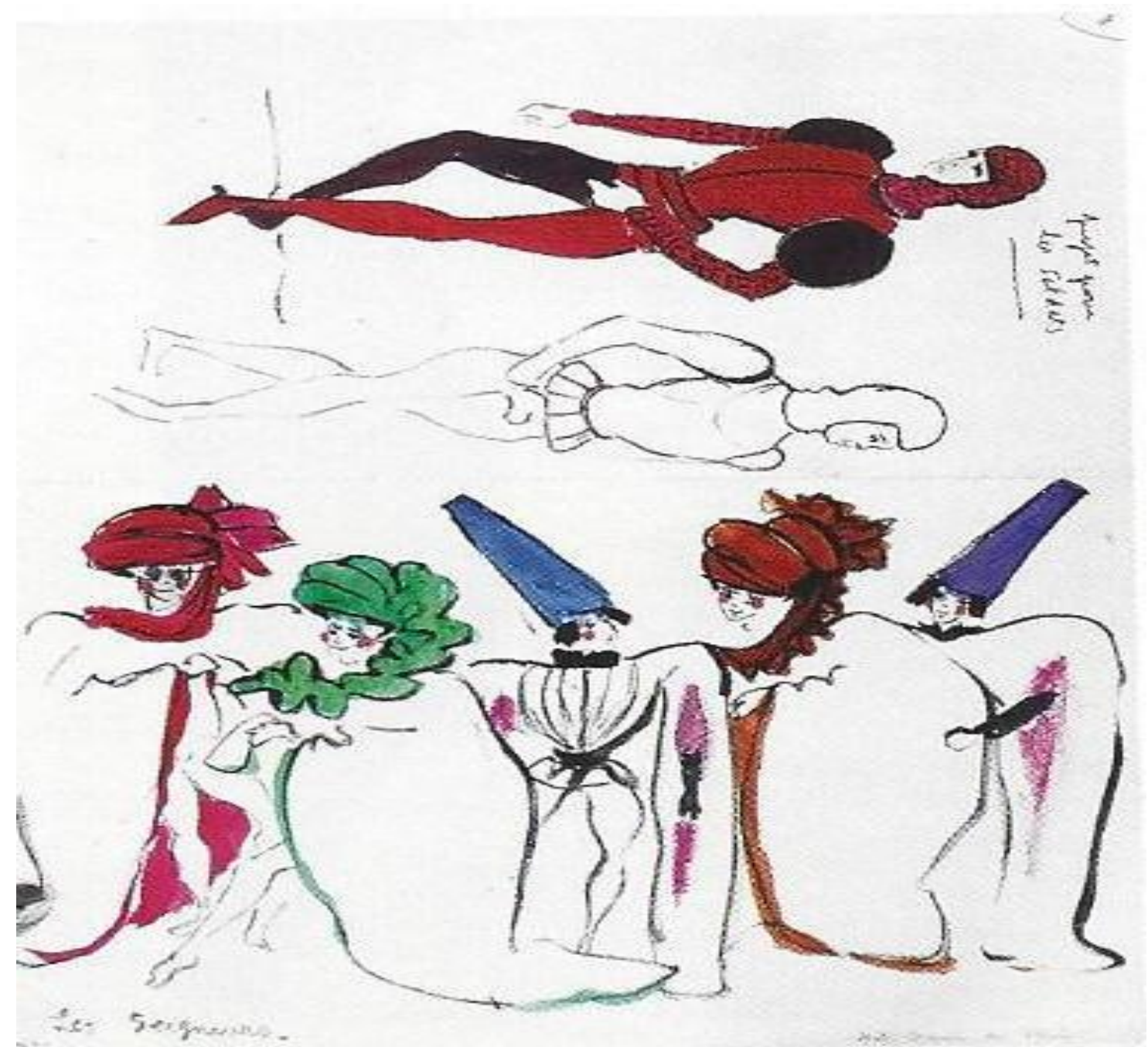

Figura 66 - SAINT LAURENT, Yves. . Projet pour les soldats, les seigneurs (Projeto para os soldados, os senhores). Giz, tinta e guache sobre o papel, 50 x 64,5 cm. Fonte: FIETTE. 2007, 91 


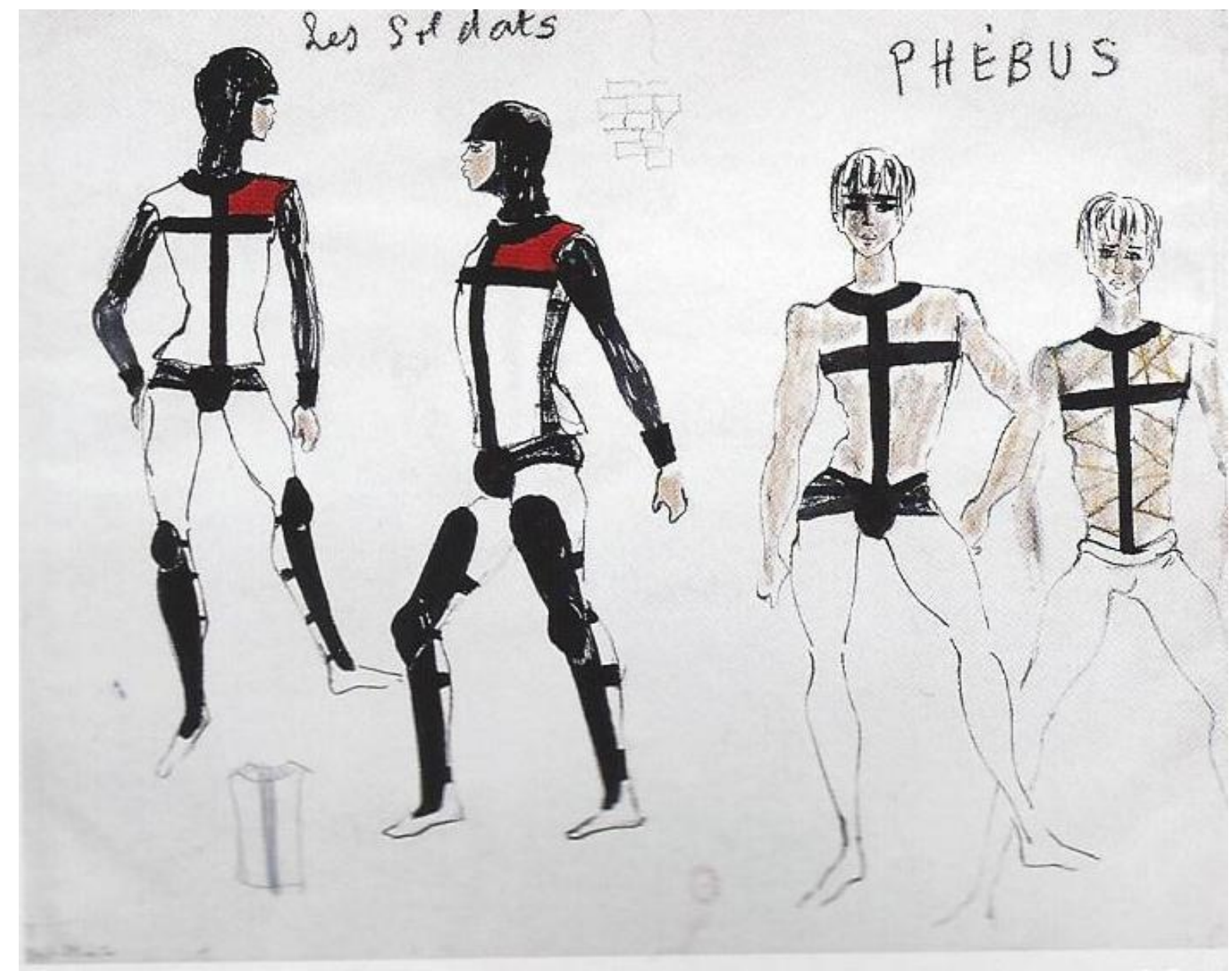

Figura 67 - SAINT LAURENT, Yves. . Os soldados, Phébus (Os soldados, Phébus). Lápis, giz e tinta sobre o papel, 50 x $64 \mathrm{~cm}$. Fonte: FIETTE. 2007, 91. 


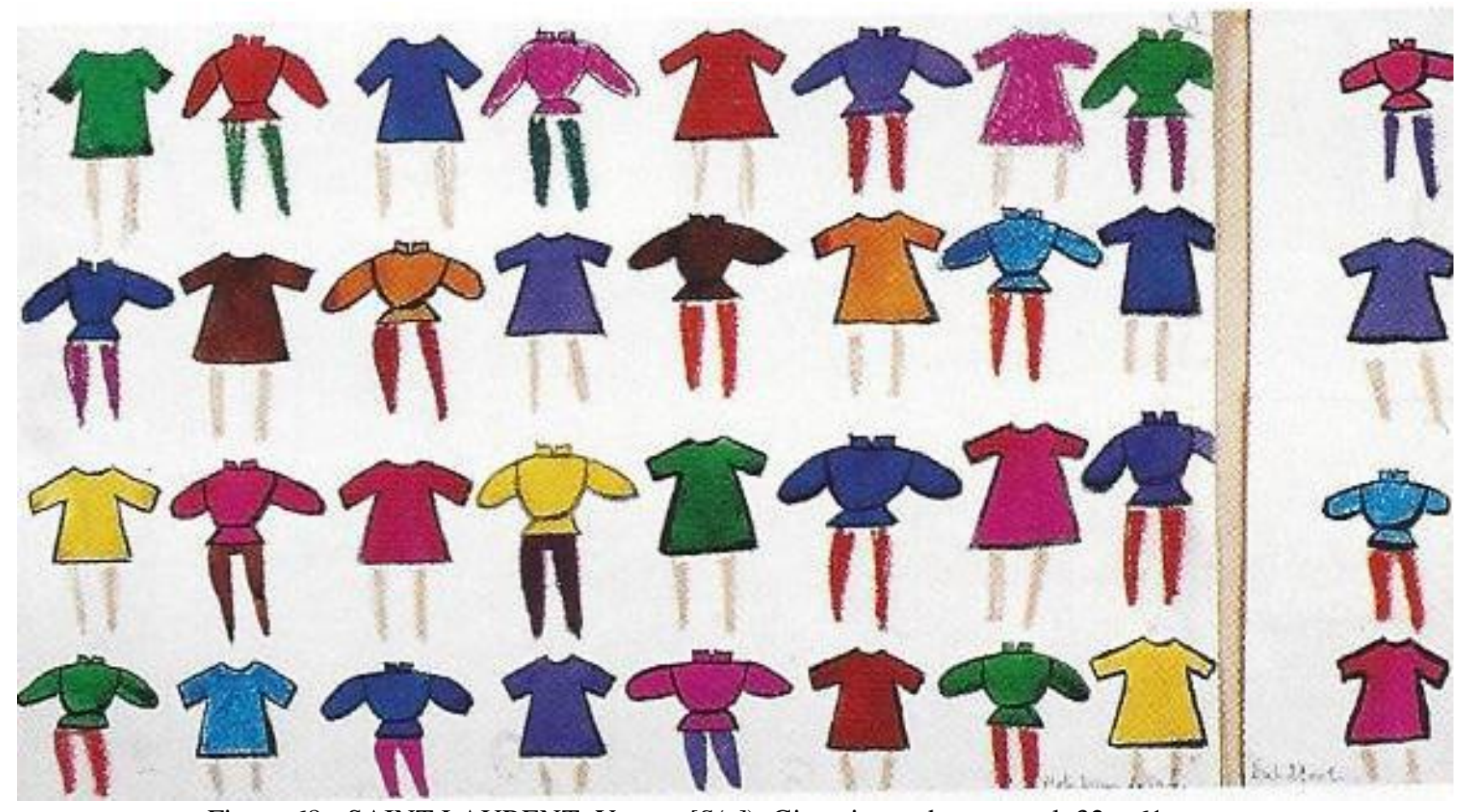

Figura 68 - SAINT LAURENT, Yves. . [S/n]). Giz e tinta sobre o papel, 32 x $61 \mathrm{~cm}$.

Fonte: FIETTE. 2007, 89. 


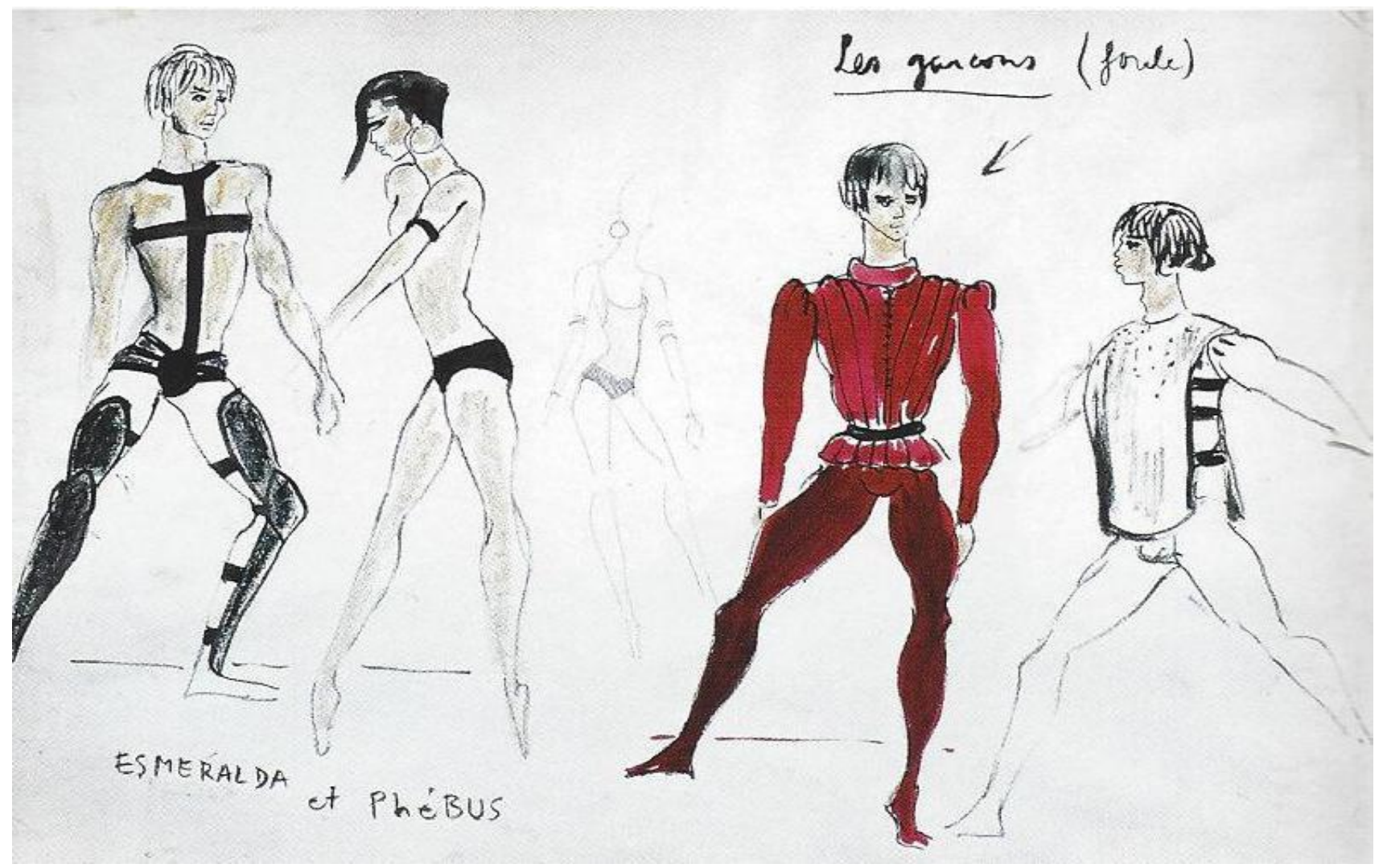

Figura 69 - SAINT LAURENT, Yves. . Esméralda et Phébus, les garçons. (Esmeraldae Phœbus os meninos). Lápis, giz e tinta sobre o papel, 48 x 64cm. Fonte: FIETTE. 2007, 88. 


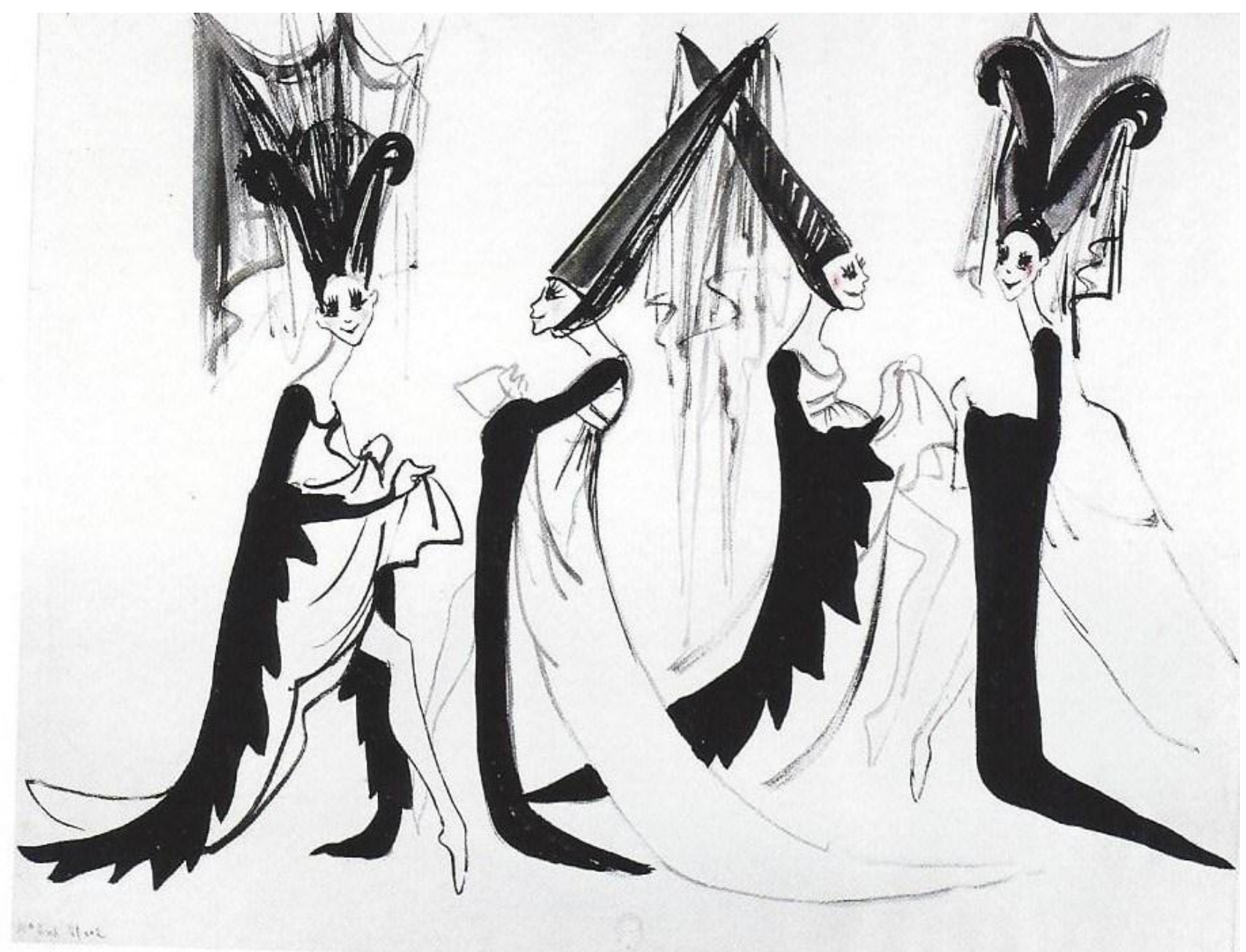

Figura 70 - SAINT LAURENT, Yves. . [S/n]). Giz e tinta sobre o papel, 48 x $64 \mathrm{~cm}$. Fonte: FIETTE. 2007, 88. 


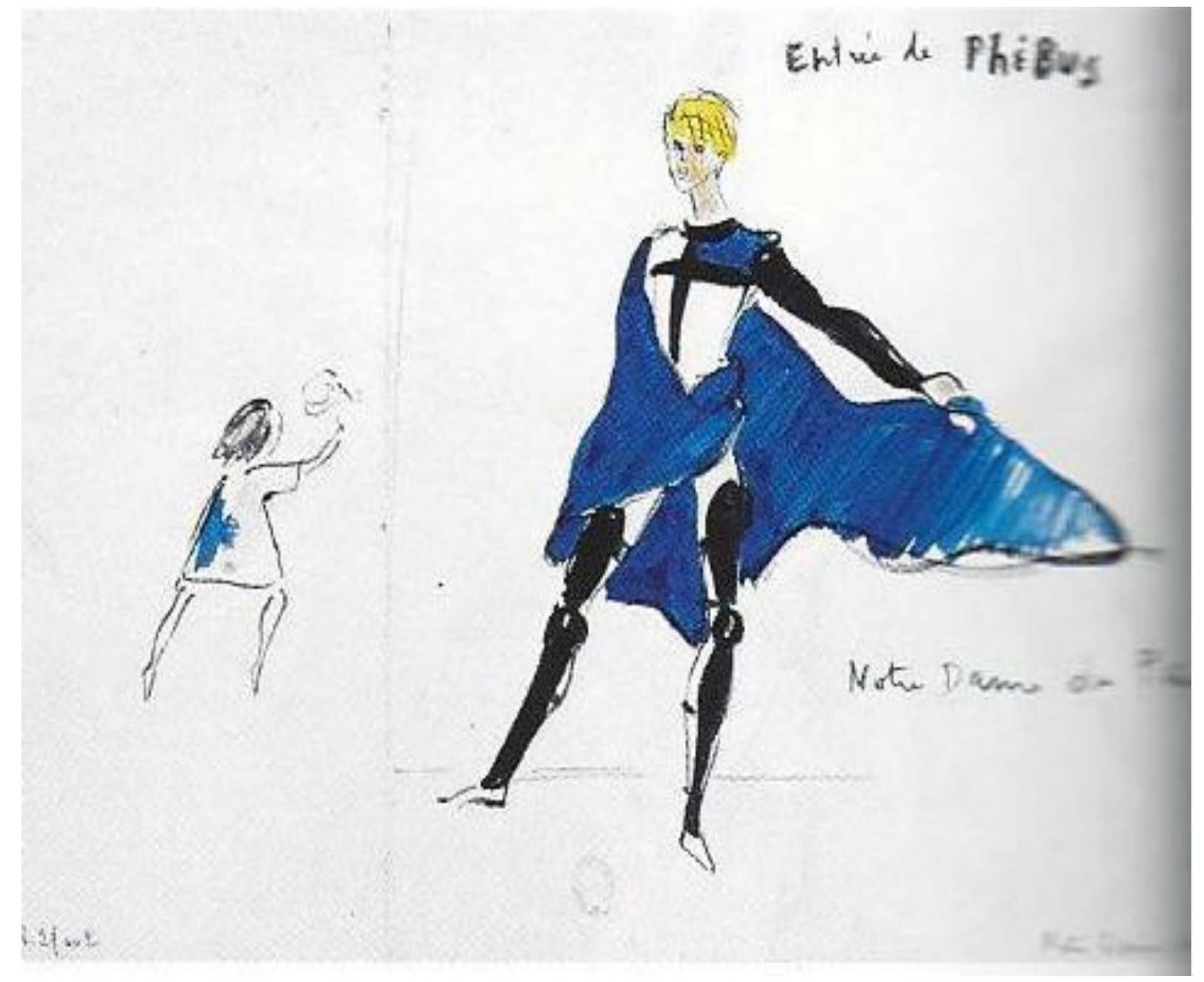

Figura 71 - SAINT LAURENT, Yves. . Entrée de Phébus. (Entrada de Phœbus). Giz e tinta sobre o papel, 32,5 x $50 \mathrm{~cm}$. Fonte: FIETTE. 2007, 91 


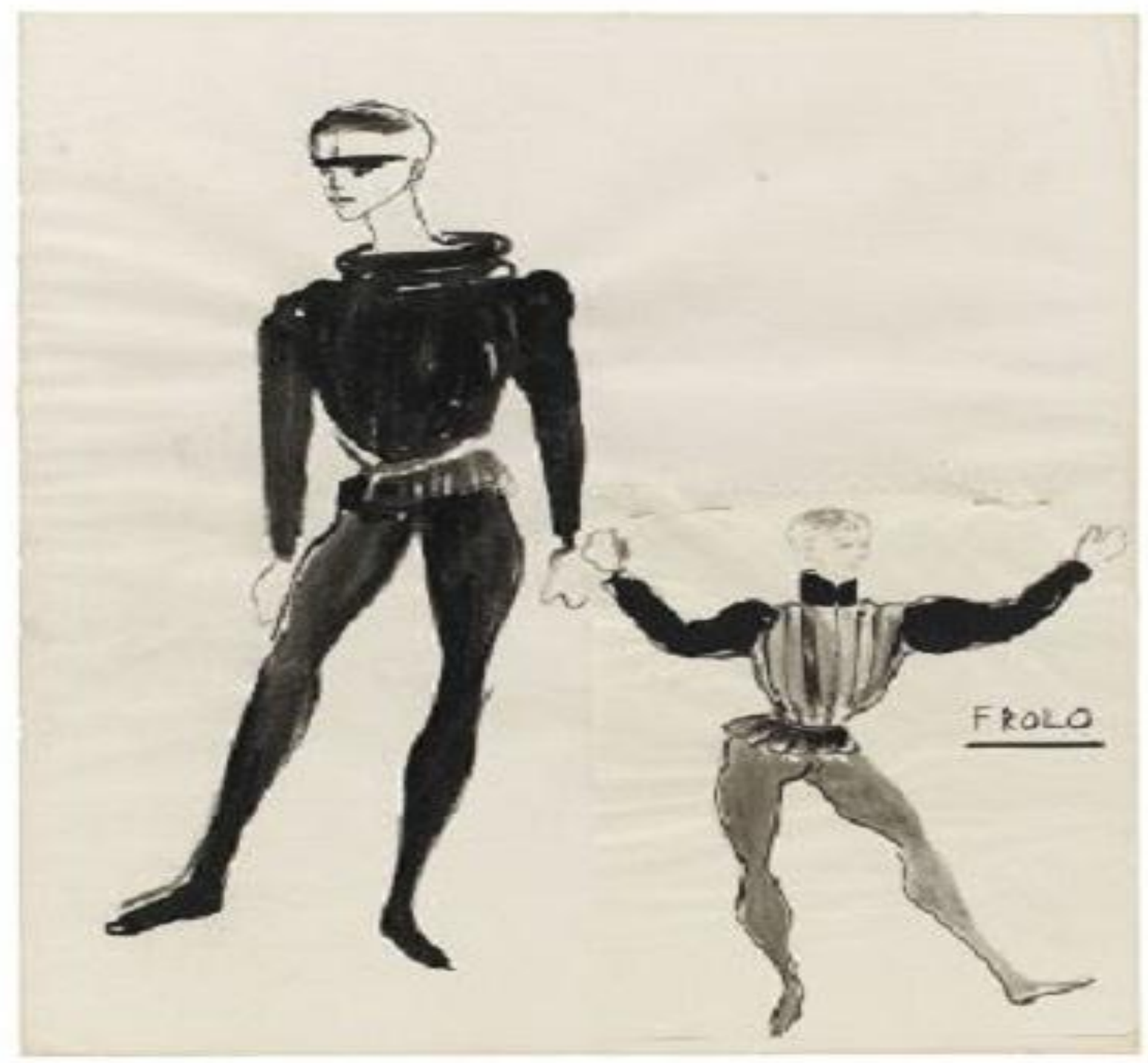

Figura 72 - SAINT LAURENT, Yves. . Frollo. Giz e tinta sobre o papel, 26 x 20,8 cm.

Fonte: FIETTE. 2007, 88. 


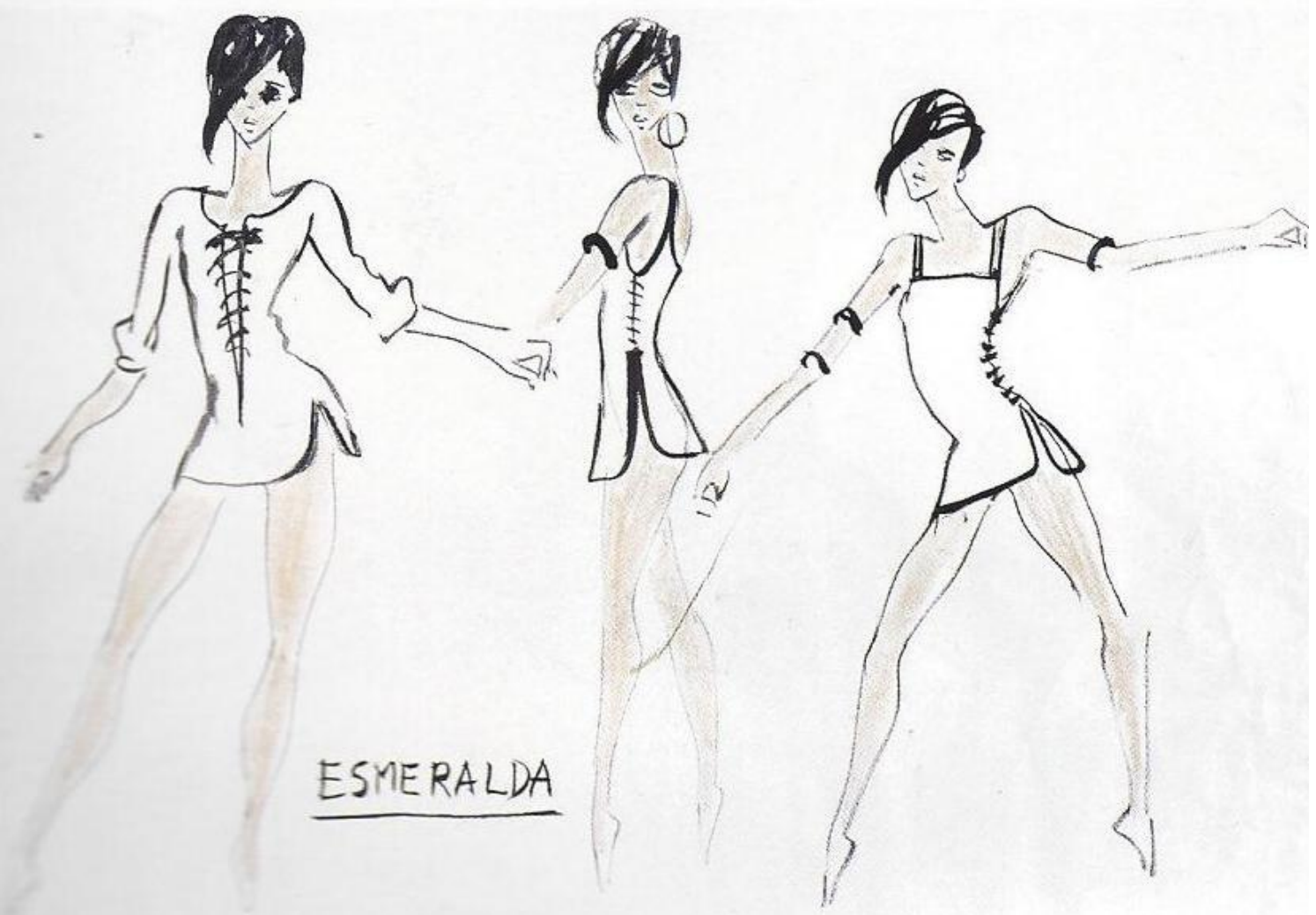

Figura 73 - SAINT LAURENT, Yves. . Esméralda. Lápis, giz e tinta sobre o papel, 50 x 54,5 cm. Fonte: FIETTE. 2007, 88. 


$$
n
$$




\section{II - Libreto do balé Notre-Dame de Paris, por Roland Petit}




\section{LIBRETO DE NOTRE-DAME DE PARIS ${ }^{130}$, POR ROLAND PETIT ${ }^{131}$}

PRIMEIRO ATO

\section{A festa dos loucos}

No ano de graça de 1482, naquela Paris de Luís XI, confinado entre NotreDame, o Louvre e o Châtelet - Deus, o Rei e a Justiça - burgueses e palhaços se reúnem para celebrar a "festa dos loucos". Quem melhor fizer caretas e palhaçadas de todos os tipos levará o título de "Papa dos Loucos". De repente, aparece um ser monstruoso que eclipsa todos os outros: corcunda e coxo, é Quasimodo, o tocador de sino de NotreDame. Mas sua deformidade não é finta, ela é real. Aos seus olhos, a multidão fica por um instante tomada de estupor, em seguida, cruelmente zombadora, o proclama "Papa dos Loucos" e conduz o pobre enfermo, confusamente feliz com seu título derrisório, a um passeio em um cortejo grotesco.

\section{A oração}

Porém, alguém perturba a festa: Claude Frollo, o arquidiácono de Notre-Dame, o qual lembra ao povo de que a vida não é feita somente de prazeres e que é preciso rezar e se arrepender. Envergonhado, Quasimodo vai, tal como um cão fiel, deitar-se a seus pés, pois é a esse padre de aparência dura e austera que ele deve a vida. Bebê abandonado, prometido à fogueira por algumas comadres que viam em sua monstruosidade um sinal do Diabo, foi Frollo que o recolheu, o criou e o tornou o tocador de sino da catedral. Sob a máscara da frieza e da severidade, Frollo dissimula uma alma atormentada desde que percebeu, dançando diante da esplanada de NotreDame, uma certa "egípcia" de nome Esmeralda. É em vão que ele tenta orar: o som da pandeireta, intolerável obsessão, zumbe sem cessar em seus ouvidos.

\section{Esmeralda}

Eis então que justamente ela aparece, tão bela "que Deus a teria preferido no lugar da Virgem", dançando com seu corpo de fogo, como um convite ao amor. Louco de desejo, Frollo ordena a Quasimodo ir pegar Esmeralda e trazê-la para ele.

130 Tradução de Lucas Kadimani 


\section{O pátio dos milagres}

Começa então uma terrível perseguição, Quasimodo procurando Esmeralda em Paris, entre o povo das sombras: errantes, enfermos, mendigos, larápios, batedores de carteira, assassinos, todos aqueles renegados do pátio dos milagres, cuja noite é o reino.

\section{O pelourinho}

Esmeralda consegue escapar de Quasimodo graças à intervenção de uma companhia de arqueiros, conduzida pelo belo capitão Phœbus. A boêmia é imediatamente seduzida pelo belo oficial, enquanto Quasimodo, apreendido, é conduzido ao pelourinho pelos arqueiros que o espancam, sob os olhos complacentes dos andarilhos. Só Esmeralda, comovida pelo sofrimento cujo aspecto a havia inicialmente assustado, atravessa a multidão para lhe dar de beber. Esse simples gesto de piedade, o único que provavelmente já lhe haviam manifestado, e vindo de uma moça cuja beleza é tão intensa quanto à fealdade dele, vai transtornar a alma do pobre diabo e mudar o curso de seu destino.

\section{Os soldados}

Phoebus desfila liderando suas tropas. Como uma parada amorosa destinada a Esmeralda.

\section{A taverna}

Phoebus leva a boêmia a uma taverna frequentada pelos mercenários e meretrizes. Esmeralda logo se encontra nos braços do belo capitão. Mas os amantes não estão sozinhos. Na sombra, Claude Frollo assiste, tomado de raiva e ciúmes, às suas brincadeiras. Frollo apunhala Phoebus e foge, deixando Esmeralda completamente transtornada. Tendo em vista o que as aparências acusavam, os cavaleiros que estavam em ronda levam a egípcia.

\section{O processo}

Acusada pelo assassinato de Phoebus, Esmeralda é conduzida aos seus juízes. 
A forca

Culpada por depravação, homicídio e feitiçaria, a cigana Esmeralda é condenada a ser enforcada. Ela já está nas mãos do carrasco quando, de repente, surge Quasimodo, que não esqueceu o gesto da boêmia. Empurrando a guarda, ele liberta Esmeralda e a transporta ao interior da catedral. Abrigada em Notre-Dame, Esmeralda será beneficiada do direito de asilo. Claude Frollo, apesar de seu despeito, só pode parar a multidão que buscava se lançar na igreja. Decepcionada por lhe terem tirado sua preza, mas voltando aos sentimentos religiosos, a assistência se contenta em lançar gritos de alegria: "Natal!", para celebrar o nascimento do Salvador.

\section{SEGUNDO ATO}

\section{O sino de Notre-Dame}

Continuamente à espreita, Quasimodo percorre seu lar para assegurar que nada ameace sua bela protegida. Ele deixa sua alegria extravasar pendurando-se nos sinos e fazendo-os soar a toda velocidade.

\section{Esmeralda e Quasimodo}

Surge Esmeralda que, com ternura, demonstra sua gratidão pelo tocador de sinos. Este, envergonhado com seu corpo disforme, sente-se, contudo, motivado encorajado por ela - até tomar a mão da moça e lhe fazer, todo feliz, as honras do refúgio. Esgotada, Esmeralda adormece suavemente, protegida por Quasimodo. Acreditando que estivesse em segurança, o corcunda se afasta. Mas a catedral também é o lar do arquidiácono Frollo. Aproveitando da ausência de Quasimodo, este vem atormentar Esmeralda. Ela rejeita seus abraços com desgosto. Então, levado por seu delírio passional, o homem bate, como para quebrar para sempre aquele corpo que lhe resiste.

\section{O pesadelo - o ataque à catedral}

A justiça não pode ser desafiada por muito tempo! Tendo uma sanção do Parlamento revogado o direito de asilo, os soldados atacam a catedral. O povo segue e Quasimodo, impotente, ver invadirem, em um pesadelo, soldados e mulheres descabeladas, como as fúrias da Antiguidade. Ele tenta em vão pará-los jogando neles 
chumbo derretido mas, submergido pela quantidade, ele tem de abandonar a luta. Esmeralda é pega.

\section{A morte}

Um longo cortejo conduz Esmeralda à forca, nada mais poderá impedir o carrasco de concluir seu trabalho. A bela boêmia não é mais do que uma forma inerte. $\mathrm{E}$ morrem com Esmeralda os sons da pandeireta, que assombravam as noites do arquidiácono. Quasimodo enfim percebe o poder maléfico desse homem, o corcunda lança-se contra ele e o estrangula. O corpo do padre maldito rola pelos degraus da forca, enquanto Quasimodo carrega lentamente os restos mortais desarticulados daquela que ele amou. 